United States Department of Energy Environmental Restoration and Waste Management PFENED
FER 24994
OSTI

\title{
Site Maps and Facilities Listings
}

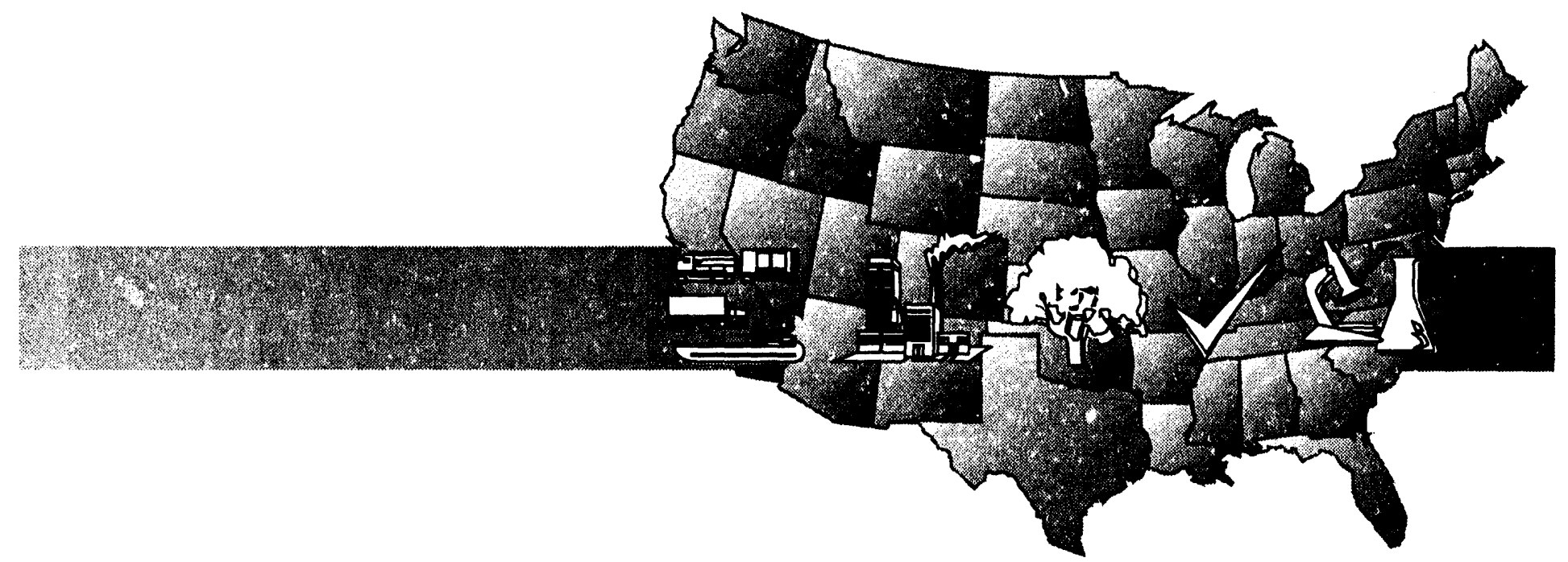




\section{INTRODUCTION}

In September 1989, a Memorandum of Agreement among DOE offices regarding the environmental management of DOE facilities was signed by appropriate Assistant Secretaries and Directors. This Memorandum of Agreement establi shed the criteria for EM line responsibility. It stated that EM would be responsible for all DOE facilities, operations, or sites 1) that have been assigned to DOE for environmental restoration and serve or will serve no future production need; 2) that are used for the storage, treatment, or disposal of hazardous, radioactive, and mixed hazardous waste materials that have been properly characterized, packaged, and labelled, but are not used for production; 3) that have been formally transferred to EM by another DOE office for the purpose of environmental restoration and the eventual return to service as a DOE production facility; or 4) that are used exclusively for long-term storage of DOE waste material and are not actively used for production, with the exception of facilities, operations, or sites under the direction of the DOE Office of Civilian Radioactive Waste Management.

As part of the implementation of the Memorandum of Agreement, Field Offices within DOE submitted their listings of facilities, systems, operation, and sites for which EM would have line responsibility. It is intended that EM facility listings will be revised on a yearly basis so that managers at all levels will have a valid reference for the planning, programming, budgeting and execution of EM activities.

Over the past three-plus years, many changes affecting the original list of EM facilities have occurred. The first updating of the original list was published in November 1992. This document is the second update.

The compilation of this listing and associated maps for sites, facilities, and operations that are the responsibility of the Office of Environmental Restoration and Waste Management has been a cooperative effort. The basic data were generated at the various sites and Operations offices and sent to DOE Headquarters where they were collected and transcribed into a standard format. The resultant draft was reviewed at DOE Headquarters prior to being published in final form. 


\section{FOREWORD}

This compilation includes 40 individual DOE sites grouped under ten Operations Offices. As shown in the Table of Contents that follows, the number of sites assigned to individual Field Offices varies from one (Fernald, Richland, Rocky Flats, and Savannah River Operations Offices) up to 12 in the case of Aibiquerque Operations Office.

No attempt is made in this document to present a complete inventory of every EM facility at each of the sites. (For the purposes of this document, "Facility" is defined as an individual building, group of related buildings, storage tank or group of tanks, waste pit or pits, a groundwater area under an entire site, and the like.) As thus defined, EM presently has several thousand facilities at these 40 sites. Complete listing of these facilities can be found in individual Site Waste Manayement Units Reports, Maste:- Facility Custodian Lists, and the like. In the future, an EM Facilities Data Base will be maintained by EM-60. $A D$ will maintain EM's facility data as part of the DOE Real Property Information System. 
TABLE OF CONTENTS

EM SITE MAPS AND FACILITIES LISTINGS

OFFICE-SITE

PAGE

\section{Albuquerque Operations Office}

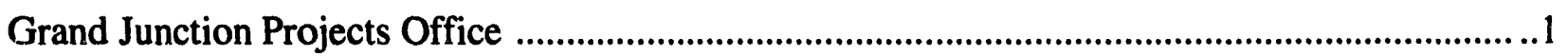

Inhalation Toxicology Research Institute ..................................................................................4

Kansas City Plant ...................................................................................................................

Los Alamos National Laboratory ....................................................................................11

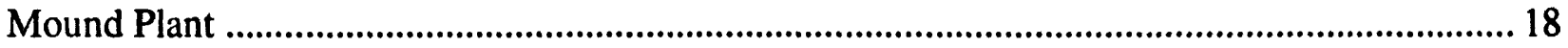

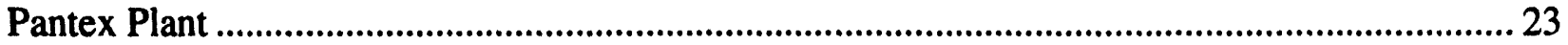

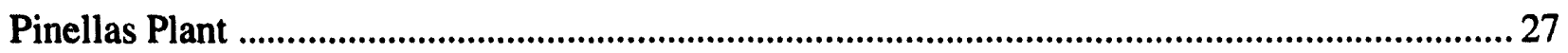

Sandia National Laboratories - California …………….............................................................. 31

Sandia National Laboratories - New Mexico ……................................................................... 33

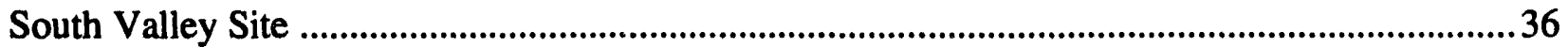

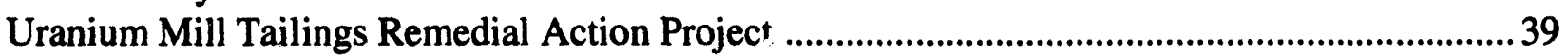

Waste Isolation Pilot Plant ........................................................................................................ 47

\section{Chicago Operations Office}

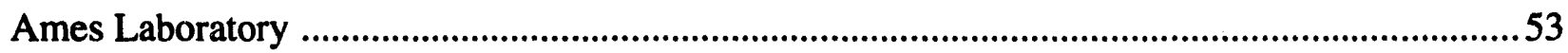

Argonne National Laboratory - East ......................................................................................... 56

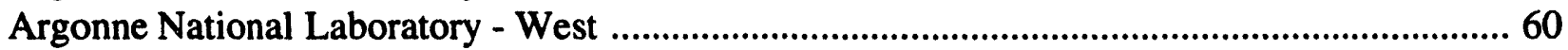

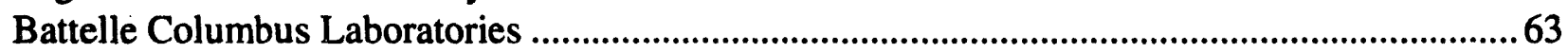

Brookhaven National Laboratory.............................................................................................69

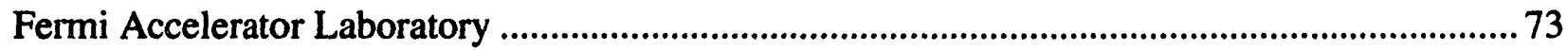

Princeton Plasma Physics Laboratory ................................................................................... 76

\section{Fernald Operations Office}

Fernald Environmental Management Project............................................................................... 78

\section{Idaho Operations Office}

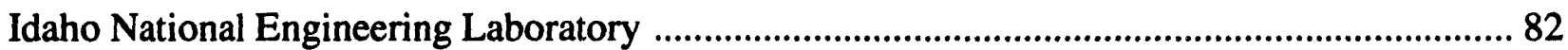

West Valley Demonstration Project Office ........................................................................... 92

\section{Nevada Operations Office}

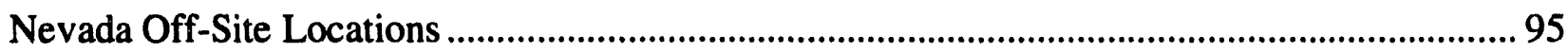

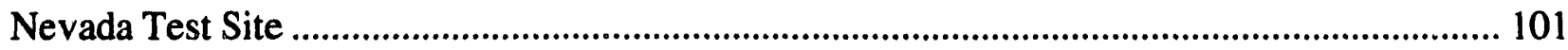




\section{Oak Ridge Operations Office}

Formerly Utilized Sites Remedial Action Program ......................................................................107

Oak Ridge Gaseous Diffusion Plant (K-25 Site) .................................................................. 115

Oak Ridge National Laboratory ............................................................................................. 134

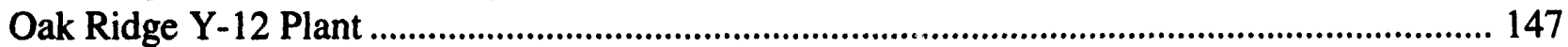

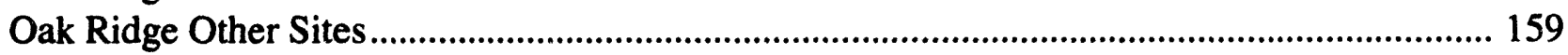

Paducah Gaseous Diffusion Plant .................................................................................................. 164

Portsmouth Gaseous Diffusion Plant ......................................................................................... 169

Weldon Spring Site Remedial Action Project ........................................................................... 173

\section{Richland Operations Office}

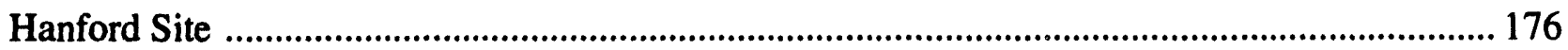

\section{Rocky Flats Office}

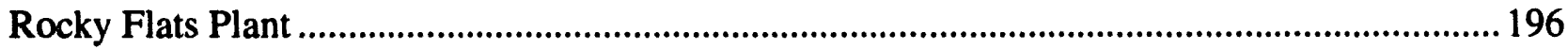

\section{San Francisco Operations Office}

Laboratory for Energy-Related Health Research ......................................................................2204

Lawrence Berkeley Laboratory ..................................................................................................2 208

Lawrence Livermore National Laboratory ................................................................................. 210

Santa Susana Field Laboratory .............................................................................................2218

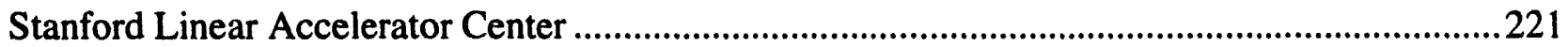

Savannah River Operations Office

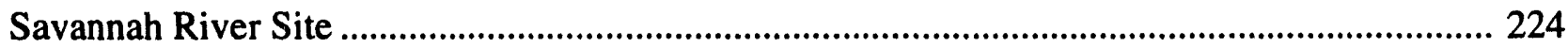




\section{GRAND JUNCTION PROJECTS OFFICE}

\section{ENVIRONMENTAL RESTORATION AND WASTE MANAGEMENT FACILITIES}

\section{DESCRIPTION}

The Grand Junction Projects Office (GJPO) facility occupies 56.4 acres immediately south and west of Grand Junction, Colorado, on the Gunnison River. GJPO was originally established in 1943 under the Manhattan Engineer District and was operated by the U.S. Vanadium Corporation as a uranium refinery for the Federal Government. In 1947, the site became the Colorado Raw Materials Office for the Atomic Energy Commission (AEC) and administered the U.S. defense-related uranium exploration and purchase programs. GJPO then managed the National Uranium Resource Evaluation (NURE) program. In 1972, the state and AEC began the Grand Junction Remedial Action Project to clean up several hundred contaminated vicinity properties in the community. In the early 1980 s, the remediation of approximately 4,000 vicinity properties was initiated under the Uranium Mill Tailings Remedial Action Project. The GJPO was accepted into the DOE D\&D Program in 1988. In April 1992, GJPO was transferred from the DOE-ID Field Office to DOE-AL for administrative direction. The GJPO operates the government-owned facility for the purpose of planning and managing a variety of remedial action projects. A project to clean up the GJPO compound is approximately $82 \%$ complete inclucling the remediation of an estimated 245,000 cubic yards of uranium mill-tailings on the site.

The Monticello Remedial Action Project consists of a DOE-owned 78 acre millsite and adjacent contaminated peripheral properties located partly within and south of the city of Monticello, Utah. The Monticello Vicinity Properties (MVP) project consists of approximately 400 properties primarily contaminated with wind-deposited tailings. There is an estimated 2.6 million cubic yards of contamination that will be removed from the sites. The remedial action by the MVP consists of excavation of contamination and transport to the millsite for temporary storage. Remedial action started in 1984 and is still continuing. Remedial action of the millsite consists of excavation of contamination and removal to a permanent disposal facility. The remediation of the millsite started in 1991 with the closure of several mill production wells that were a potential conduit for contamination of drinking water to aquifers underlying the millsite. Remediation has continued with the construction of facilities that will be used to support the tailings excavation.

GJPO also operates a full-service analytical chemistry laboratory, an earth sciences and geochronology laboratory, a radon laboratory which also serves as a radon standards laboratory for the nation, a petrology laboratory, and an electronics/instrument calibration facility for state-of-the-art equipment support.

\section{AGREEMENTS}

Statute/Type

CERCLA Federal Facility Agreement $\underline{\text { Facilities }}$

Monticello, Utah $\underline{\text { Parties }}$

$\underline{\text { Status }}$

DOE/EPA/UT
Completed 12/23/88 


\section{FACILITIES AND PROJECTS}

Buildings 7, 12, 20,31A, 33, 42,61A-C,938, and 3022: Satellite Accumulation Areas (SAA) for low-level hazardous waste.

Building 7, 20,33, 42, and 61A.C: Temporary Storage Areas (TSA) for small quantities of toxic substances. Building 36: Radioactive Source Storage Area.

Grand Junction Projects Office Remedial Action Project: Radiological contamination was assessed in 1985, 1989, 1990, and 1993. 


\section{GRAND JUNCTION PROJECT OFFICE}

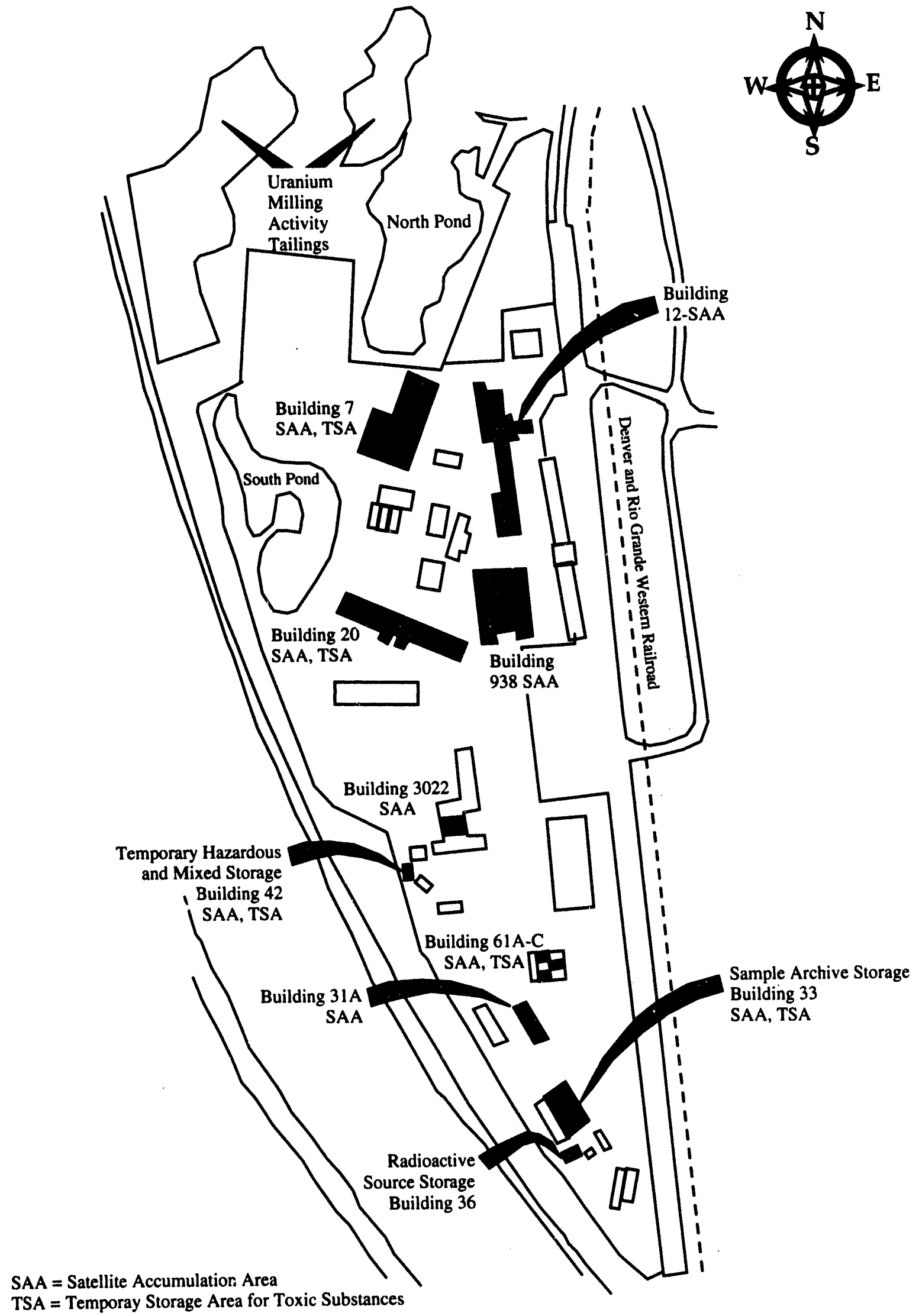




\section{INHALATION TOXICOLOGY RESEARCH INSTITUTE}

\section{ENVIRONMENTAL RESTORATION AND \\ WASTE MANAGEMENT FACILITIES}

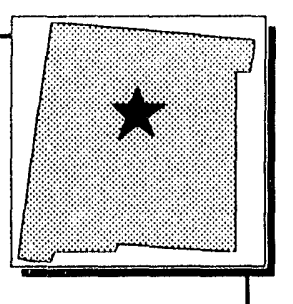

\section{DESCRIPTION}

The Inhalation Toxicology Research Institute (ITRI) occupies approximately 200,000 square feet of laboratory space on the southern edge of Kirtland Air Force Base outside of Albuquerque, New Mexico. ITRI facilities house research animals and generate sanitary, hazardous, low-level radioactive, limited transuranic, mixed, and biomedical wastes. ITRI conducts studies of the health effects of inhaling potentially hazardous airborne materials that might be found in industry, the environment, or the home. Such materials might include fission products, fuel cycle actinides, insulating materials, diesel exhaust emissions, coal combustion effluents, or other substances that might result from energy production or conservation technologies.

ITRI disposes of all hazardous wastes at EPA-permitted commercial off-site disposal sites. All radioactive wastes are disposed of at DOE-owned sites. Prior to 1992, sanitary sewage was disposed of in on-site sewage lagoons, resulting in groundwater nitrate contamination. Since May 1992, sanitary sewage has been disposed of into a municipal sewer system and the lagoons are being decommissioned. Past underground storage tank leaks have produced diesel oil contamination. Past use of small concrete-lined evaporation ponds have resulted in low-level radioactive contamination at one on-site location.

\section{AGREEMENTS}

\section{$\begin{array}{llll}\text { Statute/Type } & \text { Facilities } & \text { Parties }\end{array}$}

$\begin{array}{llll}\text { Agreement-in-Principle } & \text { DOE/NM } & \text { Completed 10/27/90 }\end{array}$

\section{FACILITIES AND PROJECTS}

Building 9252 - Treatment facility for low-level radioactive waste, includes a one-drum compacting unit.

Building 9221 - Crematory facility and compactor.

Hot Ponds - Inactive areas previously used for storage of liquid low-level radioactive waste. Assessment and remediation are ongoing.

Diesel Oil Releases - On-site locations of past leaks and spills have resulted in soil and possibly groundwater contamination. Four of five sites have been cleaned and closed. Assessment and possible remediation will be conducted on the last site.

Lagoon and Groundwater - This is a fourteen-acre area containing sewage sludge from 29 years of operation. The sludge contains primarily cesium 137 contamination. Nitrates in excess of New Mexico standards are present in groundwater 90 to 120 feet beneath the lagoons. Assessment and remediation are planned. 
INHALATION TOXICOLOGY RESEARCH INSTITUTE

Building 9222 - Low-level, mixed, and TRU waste storage.

Building 9211 - Empty drum storage facility.

Sheds 9264.9269 - Hazardous waste accumulation.

5 


\section{INHALATION TOXICOLOGY RESEARCH INSTITUTE}

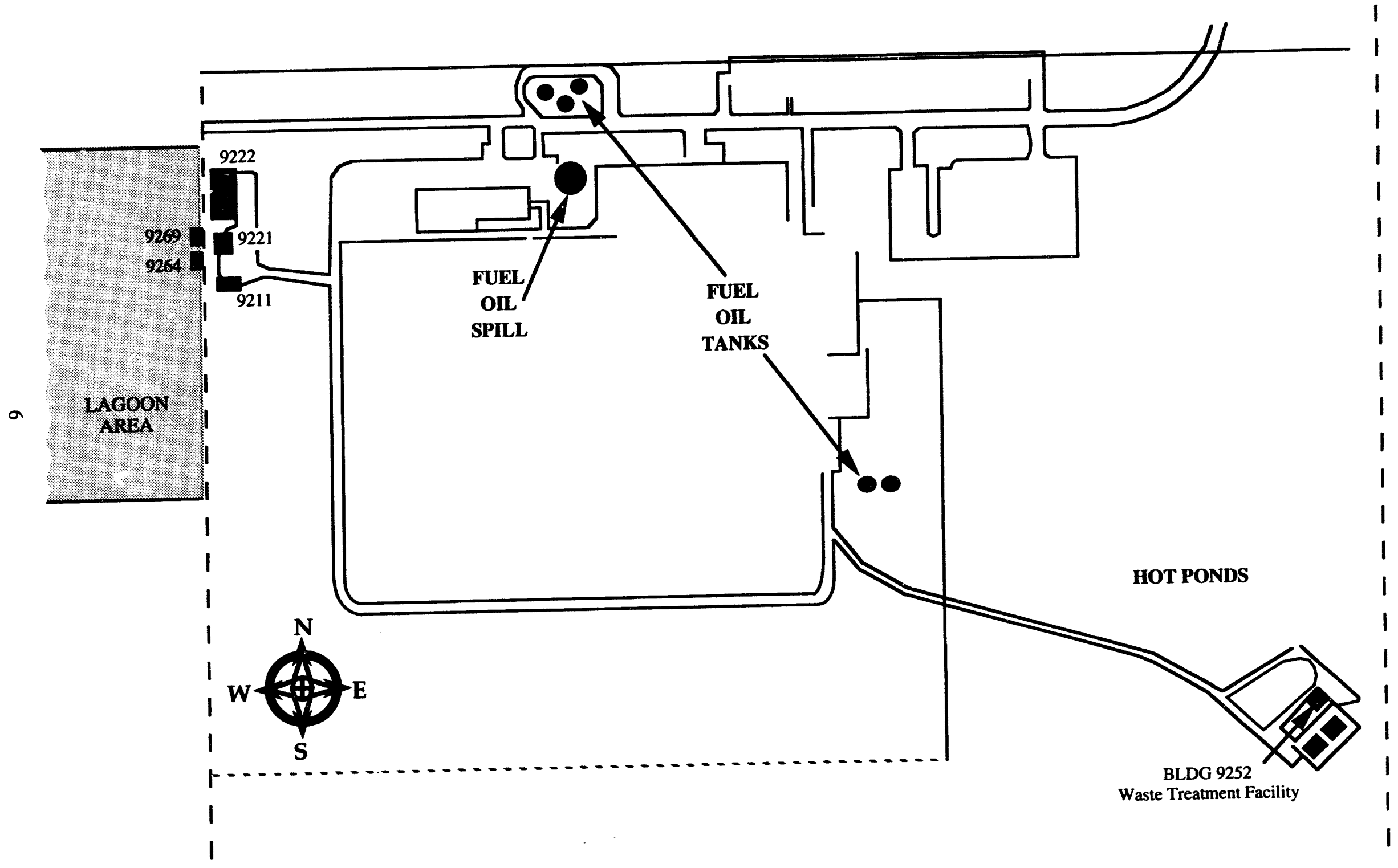




\section{KANSAS CITY PLANT}

\section{ENVIRONMENTAL RESTORATION AND WASTE MANAGEMENT FACILITIES}

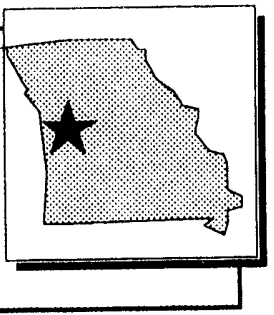

\section{DESCRIPTION}

The Kansas City Plant (KCP) is part of the Bannister Federal Complex, located 12 miles south of downtown Kansas City, Missouri. Manufacturing operations are housed in 3.2 million square feet of building space. The plant mission is the manufacture of nonnuclear weapons components involving machining, plastic fabrication, and electrical and mechanical assembly. No radioactive materials are machined or processed. Waste operations consist primarily of waste storage, off-site shipment and disposal, and on-site wastewater pretreatment for industrial process wastewaters. Thirty-seven sites are identified in the RCRA 3008(h) Administration Order on Consent for Environmental Restoration.

\section{AGREEMENTS}

\section{Statute/Type}

CERCLA Compliance

Agreement

RCRA Compliance

Agreement
Facilities

Kansas City Plant

Kansas City Plant
Parties

DOE/EPA

DOE/EPA

\section{$\underline{\text { Status }}$}

Completed 9/30/85

Completed 6/23/89

\section{FACILITIES AND PROJECTS}

\section{Tank Farm}

Curbed, concrete area for liquid hazardous waste storage housing six, on-ground storage tanks.

4-8000 gallon tanks used for oil/coolants, chlorinated and nonchlorinated solvents and PCB liquids.

2-6000 gallon tanks, one used for acid and the other used for alkaline plating waste storage.

\section{Acid Pad}

Partially covered concrete structure used for the storage of containerized acid, alkaline and cyanide wastes prior to shipment to off-site treatment, storage and disposal facility.

\section{Red-X Lot}

Covered, fenced and locked area used for the storage of mercury contaminated debris, resin, resin curing agent, paint, paint-related material, rubber compounds, adhesives and other miscellaneous ignitable materials. 


\section{L-Lot}

Concrete structure used for the storage of acid, alkaline, lead-acid batteries, returnable containers and machine turnings contaminated with water-based cutting fluids.

\section{Test Cells}

Four, enclosed, alarmed and locked concrete structures used for the segregated storage of classified hazardous waste, acidic waste, alkaline waste, and PCB waste.

\section{Reclamation Area}

Secured room used for the storage of cyanide, acid and alkaline hazardous wastes.

\section{Demolition Lot}

Curbed, partially covered, fenced concrete structure for the storage of PCB wastes, and preparation of that waste prior to transportation.

\section{Mixed Waste Facility}

Packaging and storage facility for radioactive and mixed waste used to prepare and hold materials prior to off-site disposal.

\section{IWPE}

Industrial Wastewater Pretreatment Facility used to treat various waste streams prior to discharge to the Kansas City Publicly Owned Treatment Works.

\section{Contaminated Flow Collection and Treatment System}

This project is designed to collect and treat identified toxic organic contaminated wastewater. The existing groundwater treatment system, which does not have adequate treatment capacity, will become a part of this facility. The project is currently on hold pending NEPA determination.

\section{Waste Management Building}

Waste Management Operations are responsible for all hazardous and radioactive waste management, treatment, storage, transportation, disposal, and all related handling, packaging, and administrative operations. Included in these activities are recordkeeping, reporting, permitting, waste acceptance, purchasing of containers and related supplies. Waste management also is responsible for oversight of the KCP waste generating departments.

\section{Staging Area Barrel Lot}

Area used for storage of empty containers prior to use. 


\section{ENVIRONMENTAL RESTORATION ACTIVITIES}

The listing below outlines some of the various environmental characterization and restoration activities that are ongoing at the Kansas City Plant.

1. Abandoned Indian Creek Outfall (ADS 1024) - During the 1960's and early 1970's, accidental spills of PCB heat transfer fluid entered catch basins and flowed through the storm sewer outfall and drained into Indian Creek. Although early cleanup efforts were performed, they were not thorough by today's standards.

2. Department 26 (ADS 1028) and Old Plating Building (ADS 1040) - During the early 1960's, a heat transfer fluid containing PCB's was used in the heat transfer system utilized for plastics molding operations. Although the original oil was replaced with non-PCB fluid in 1974, PCB contamination has been detected in the subsurface soils as a result of earlier piping system leakage.

3. Department 27 Inside (ADS 1029) - During the early 1960's, a heat transfer fluid containing PCB's was used in the heat transfer system utilized for plastics molding operations. Spills and leaks from the equipment resulted in contamination of the area under the equipment, through the concrete slab and possibly into the groundwater.

4. Department 27 Outside (ADS 1030) - An area outside Department 27 was the former site of a PCB distribution system. The equipment and some contaminated soil have been removed but there is still some remaining PCB contamination.

5. Miscellaneous Contaminated Sites (ADS 1032) - Refers to four sites which have been potentially contaminated with various solvents, PCB's and/or petroleum products.

6. Miscellaneous PCB Sites (ADS 1034) - A lightning strike at an electrical substation resulting in leakage of PCB containing transformer oil which contaminated concrete floors and electrical duct banks.

7. Outfall 001 Raceway (ADS 1038) - The 001 outfall is the discharge point for the 001 storm sewer which drains the north-central and northeastern portions of the site. Contamination from the Former Ponds and North Lagoon Trench Area have potentially released PCB's and VOC's to the raceway. 


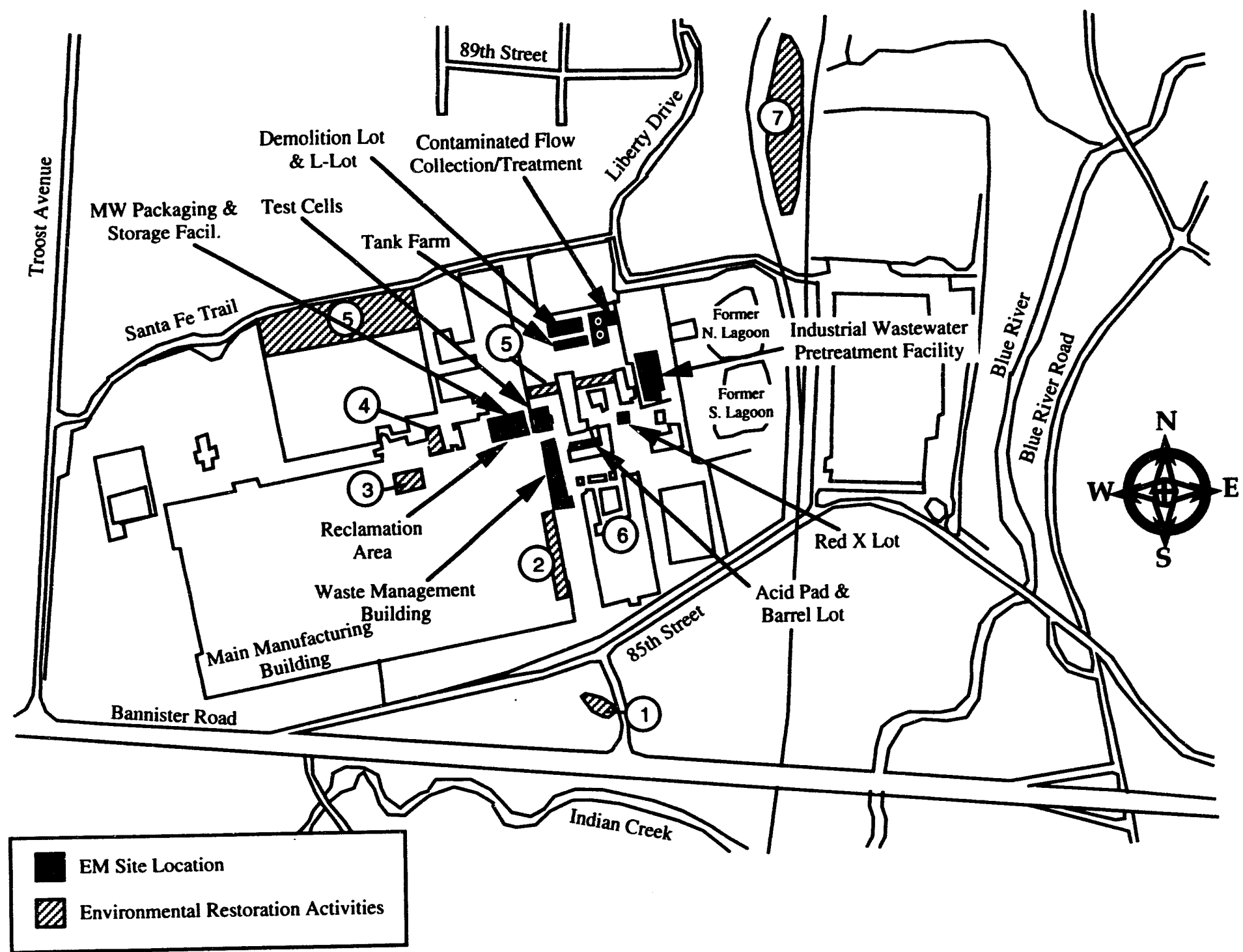




\section{LOS ALAMOS NATIONAL LABORATORY}

\section{ENVIRONMENTAL RESTORATION AND WASTE MANAGEMENT FACILITIES}

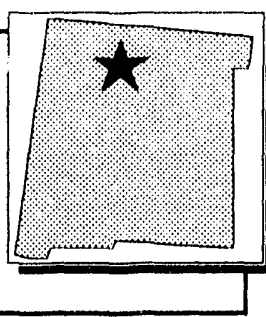

\section{DESCRIPTION}

Los Alamos National Laboratory (LANL) occupies about 43 square miles in Los Alamos County, approximately 60 miles north-northeast of Albuquerque and 25 miles northwest of Santa Fe. LANL is situated on the Pajarito Plateau, which is made up of finger-like mesas ranging in elevation from 6200 to 7800 feet. Major programs at LANL include applied research in nuclear and conventional weapons development, nuclear fission and fusion, nuclear safeguards and security, and waste management. Corrective activities include those activities necessary to bring active or standby facilities into compliance with ambient air, water, and solid waste regulations and/or agreements, and DOE requirements. Waste management is responsible for managing the hazardous, mixed, and radioactive (low-level and transuranic) wastes generated by LANL operations. Approximately 2250 potential release sites, aggregated into 24 operable units, are currently scheduled for investigation in the Environmental Restoration Program under the Hazardous and Solid Waste Amendments (HSWA) permit. Six surplus facilities are identified for decontamination and decommissioning (D\&D) in the Five-Year Plan.

\section{AGREEMENTS}

$\begin{array}{llll}\text { Statutes/Type } & \text { Facilities } & \text { Parties } & \underline{\text { Status }} \\ \text { Agreement-in-Principle } & \text { LANL } & \text { DOE/NM } & \text { Completed 10/22/90 } \\ \text { Compliance Agreement/CWA } & \text { LANL } & \text { DOE/EPA } & \text { Completed 2/13/89 } \\ \text { Compliance Agreement/RCRA LDR } & \text { LANL } & \text { DOE/EPA } & \begin{array}{l}\text { Anticipated Effective } \\ \text { Date } 1 / 94\end{array} \\ \text { HSWA Module of RCRA Permit } & \text { LANL } & & \text { Effective 5/23/90 } \\ \text { Consent Agreement/RCRA } & \text { LANL } & \text { DOE/UC/EPA } & \text { Anticipated Effective } \\ & & \text { DOE/UC/NMED } & \text { Date } 11 / 93\end{array}$

\section{FACILITIES AND PROJECTS}

\section{Technical Area 54}

Area G: $\quad$ Low-level waste disposal facility - Operations provide for the design and physical excavation of burial pits and shafts for safe and proper disposal of low-level wastes.

Solid mixed waste storage facility - Proposed 22,000 square feet reinforced concrete facility designed to receive and store contaminated liquids and solids; provide space for equipment assembly, test and storage; and, provide office and conference space. 


\section{FACILITIES AND PROJECTS (Continued)}

PCB solid waste disposal facility - All radioactively contaminated PCB waste is stored in this area. This facility also includes a compactor/baler and waste handling equipment for reducing the volume of waste and stabilizing waste for burial.

Transuranic (TRU) solid waste storage facility - Storage of uncertified and WIPP-certifiable TRU wastes in pits, trenches, shafts, under earthen cover on aboveground pads, and in self-supported fabric domes.

Building 38: TRU waste handling facility - Provides analysis of TRU wastes and verification of drum contents through nondestructive assay, real-time X-ray radiography, and other methods.

Area J: Solid waste disposal area - Administratively controlled waste, not regulated by Federal agencies, that should not be disposed of in public sanitary landfills.

Area H: Classified waste storage - Nine disposal shafts, some containing tritium, radionuclides, and high explosives.

Area L: $\quad$ Liquid mixed waste storage - Provides storage according to hazard category for mixed wastes contained in drums and boxes on an asphalt pad.

Hazardous waste storage- Permitted area that provides for the safe accumulation, packaging and storage of RCRA and TSCA-regulated hazardous wastes.

Hazardous waste staging areas and treatment tanks - Facilities for repackaging, neutralizing, precipitating and evaporating various wastes. Pads for stockpiling and transportation staging.

PCB waste storage facility - Oil, free from PCBs, is stored here for off-site incineration as a waste fuel. All soil, drained electrical equipment and other solid materials contaminated with PCBs are packaged and then shipped off-site for incineration and disposal.

\section{Technical Area 50}

Building 1: Batch waste treatment facility - Plant for pretreating and reducing concentrations of liquid radioactive wastes from the plutonium processing facility and the TRU waste size-reduction facility.

Radioactive liquid waste treatment plant - Performs primary chemical treatment and ion exchange separation processes to concentrate radioactive constituents into residues that are dewatered and packaged for storage or disposal.

TRU waste treatment plant - Treats process waste streams containing high concentrations of TRU isotopes in strong acid and caustic solutions.

Decontamination facilities - Enable waste management staff to decontaminate trucks, scrapers and other equipment. 
Building 37: Controlled air incinerator (CAI) - Used in the past to demonstrate safe incineration of TRU and mixed wastes; currently being upgraded to thermally destruct low-level mixed waste. It may subsequently be used to stabilize and reduce the volume of newly generated and stored TRU waste.

Building 69: TRU waste size reduction facility - Used for repackaging and reducing the volume of metallic wastes such as gloveboxes, process equipment and duct-work.

\section{Technical Area 21}

Building 257: Radioactive liquid waste treatment plant - Chemical treatment facility for low-level liquid radioactive wastes; treated effluent is transferred by pipeline to TA-50 for further processing. 


\section{LOS ALAMOS NATIONAL LABORATORY}

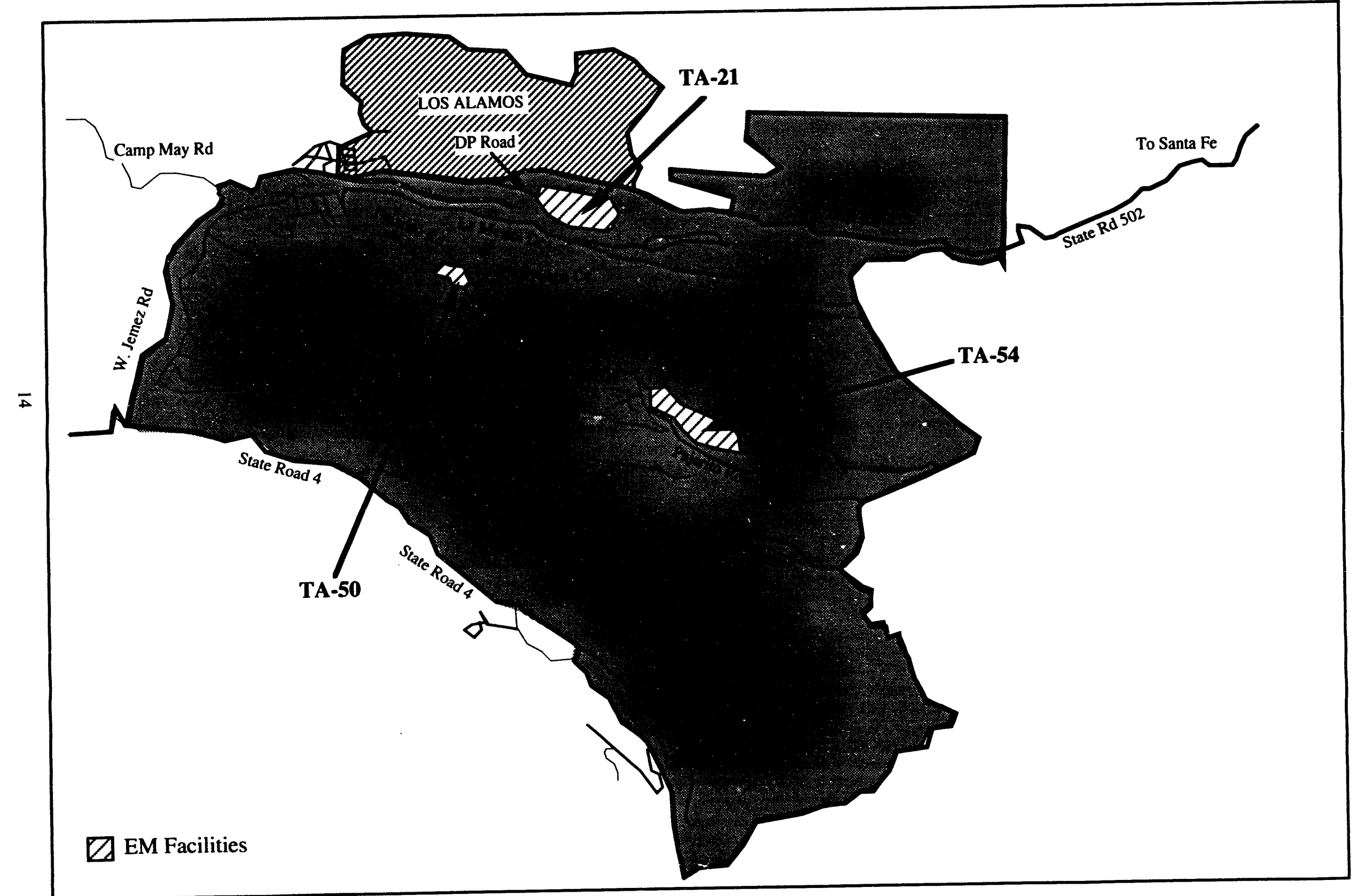




\section{LOS ALAMOS NATIONAL LABORATORY TA-54}
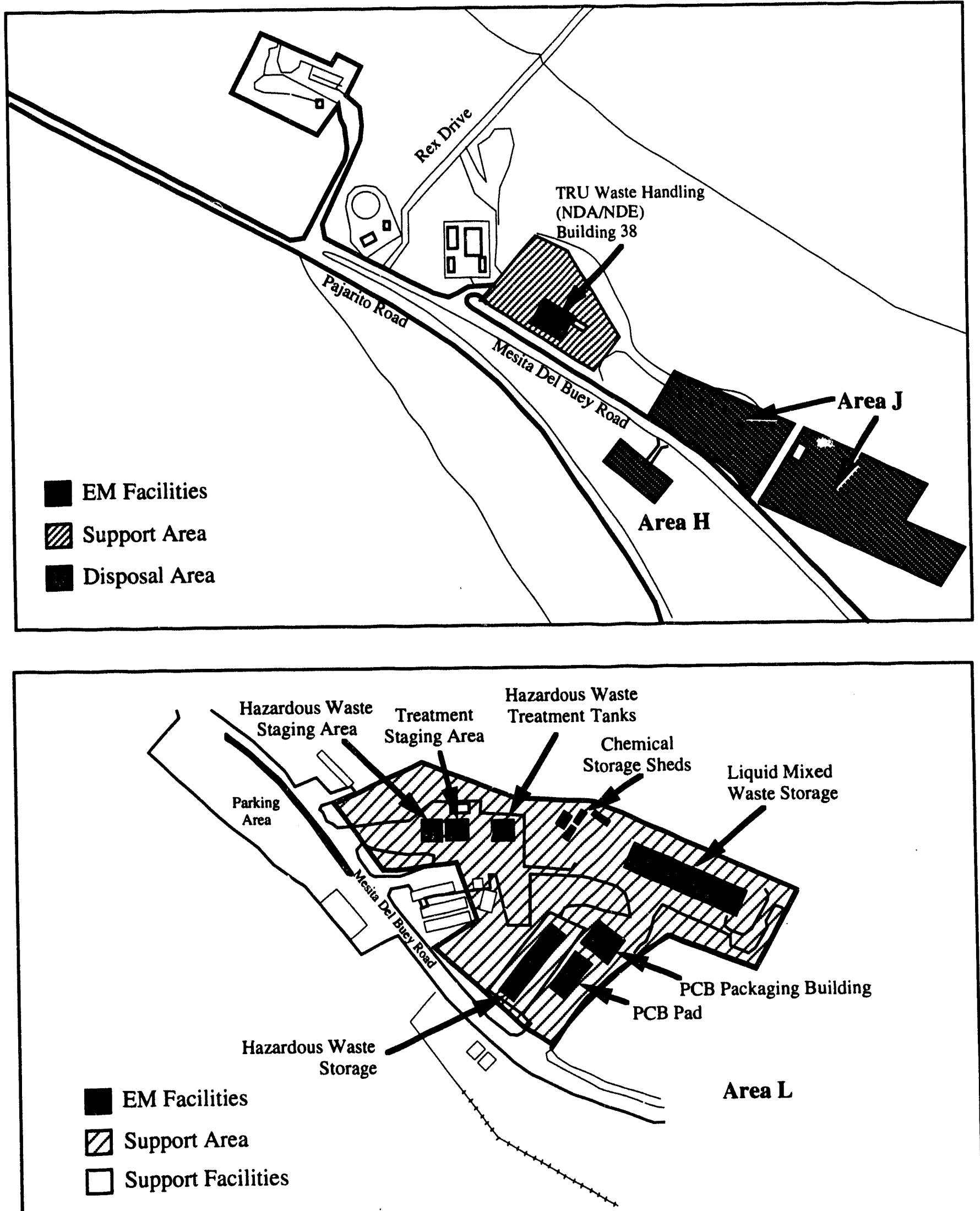


\section{LOS ALAMOS NATIONAL LABORATORY TA-54}
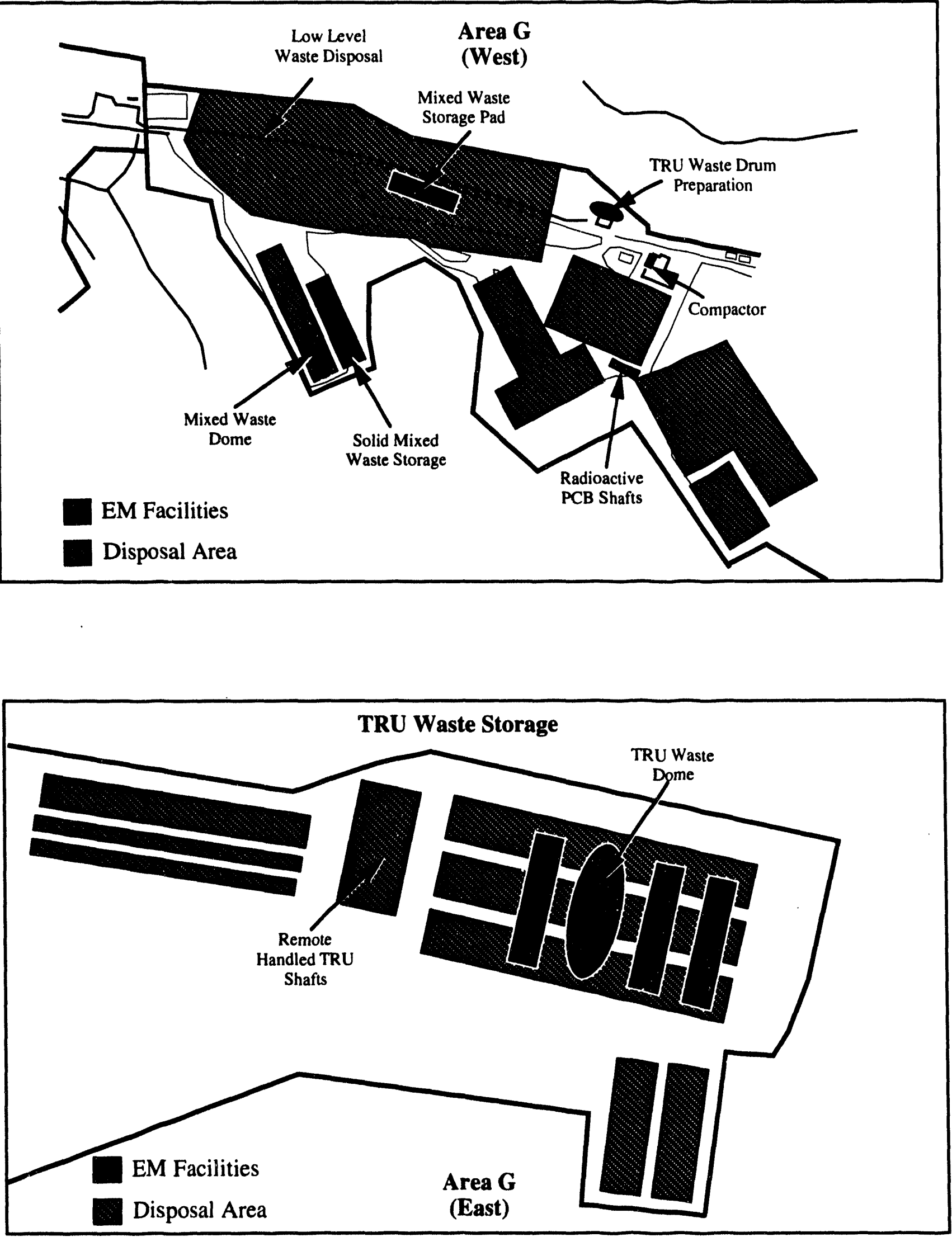


\section{LOS ALAMOS NATIONAL LABORATORY TA-50}

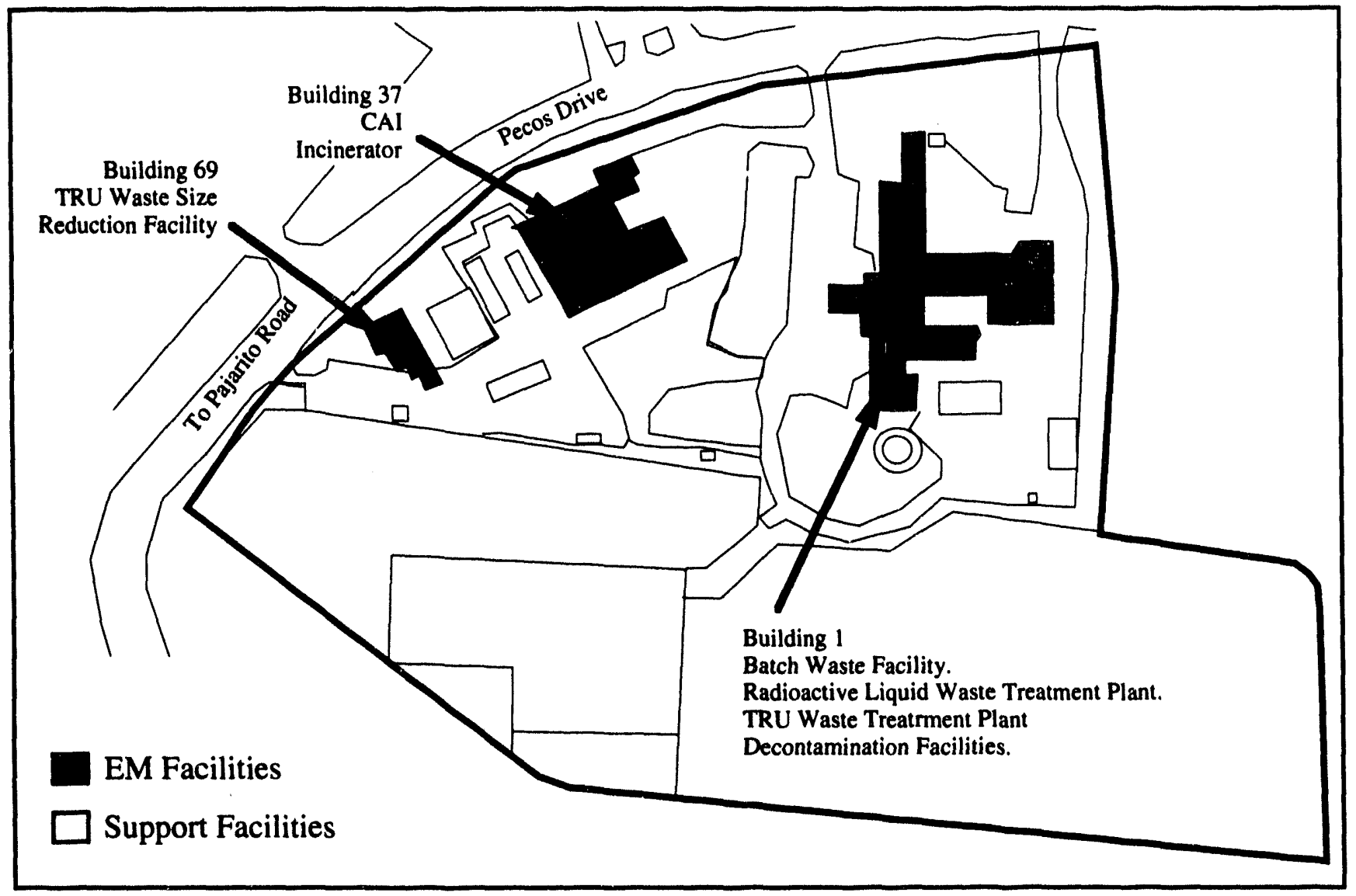

LOS ALAMOS NATIONAL LABORATORY TA-21

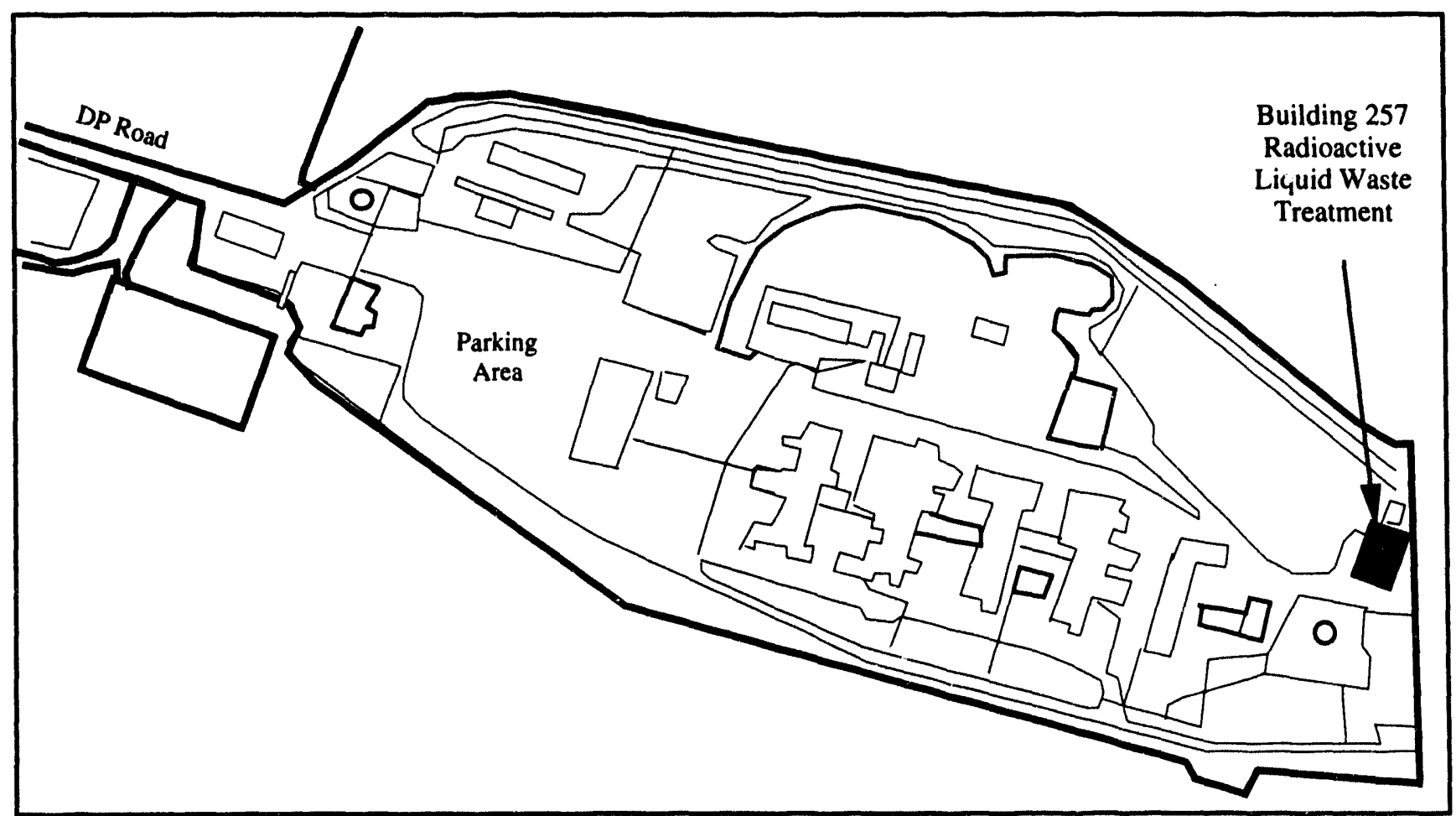




\section{MOUND PLANT}

\section{ENVIRONMENTAL RESTORATION AND WASTE MANAGEMENT FACILITIES}

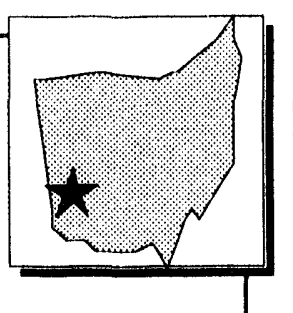

\section{DESCRIPTION}

Mound is located within the southern city limits of Miamisburg in southwestern Ohio. The plant site occupies 306 acres of land overlooking Miamisburg and Great Miami River. The Dayton metropolitan area is located ten miles northeast of the installation. Mound is an integrated research, development, and production facility operated by EG\&G Mound Applied Technologies and performs work in support of DOE weapons and energy programs. Mound manufactures nonnuclear and tritium-containing components for DOE weapons. Operations at Mound generate sanitary, hazardous, radioactive, and mixed wastes. The Mound Environmental Restoration Program includes a CERCLA cleanup program and decontamination and decommissioning (D\&D) activities. A Federal and State Facilities Agreement was successfully negotiated with EPA and the state of Ohio in July 1993.

\section{AGREEMENTS}

\section{Statute/Type}

Agreement-in-Principle

CERCLA Compliance Agreement

Federal and State Facilities Agreement Mound Plant
Parties

$\underline{\text { Status }}$

Mound Plant

$\mathrm{DOE} / \mathrm{OH}$

Under Negotiation

DOE/EPA

Completed 8/6/90

DOE/EPA/OH Completed 7/93

\section{FACILITIES AND PROJECTS}

WD Building: Inactive laboratories in the Waste Disposal Building primarily used to process plutonium-238. D\&D scheduled for approximately $25 \%$ of this 16,216 square foot building. Primary laboratories are WD-9, 10,11,13 and 110.

WDA Building: Low-level beta waste solidification facility. Building also contains glass melter thermal unit and Cyclone incinerator (not operational).

Building 23: Three-room staging area and storage facility for drummed tritiated, transuranic (TRU), non-TRU alpha and mixed wastes prior to off-site shipment.

Building 31 and 31A: Staging area for boxed tritiated, TRU and non-TRU alpha wastes prior to off-site shipment (8740 square feet).

Building 72: Principal site for hazardous waste drummed container storage facility.

Building 90: Explosives waste treatment area is equipped with a drum unit for burning explosivecontaminated material and apparatus for burning solid explosive-contaminated materials and scrap. 
Magazine 53; Explosive waste storage

Building 91: The waste management facility provides office space for Mound Plant waste management and health physics personnel.

EW Soils: Miscellaneous radioactively contaminated soil areas which total approximately seven acres comprised of 23 individual sites, the Waste Disposal (WD) Building soil, and the Sanitary Disposal (SD) Building soil.

R-Bullding: The inactive laboratory and support areas in the Research (R) Building were used primarily for research and development of plutonium-238. D\&D is scheduled for approximately one percent of this 55,003 square foot building. The primary laboratories are R-140 and R-Building overhead crawlspace.

SD Building: The Sanitary Disposal (SD) Building is an inactive sanitary waste process facility (1593 square feet) contaminated by leaks into sanitary lines from radioactive material processing areas (part of EW soils project). The SD Building is scheduled for demolition.

SM Building: The Special Metallurgical (SM) Building is a former plutonium processing facility. It is currently undergoing demolition, and is over 50 percent complete $(21,700$ square feet).

SW Building: The inactive laboratories in the Semi-Works Building were used for various radioactive material processing. $D \& D$ is scheduled for approximately 15 percent of this 43,066 square foot building. Primary laboratories are SW-8, 19, 22, 240 and Cave.

Underground Lines: There are approximately 4000 feet of inactive underground radioactive liquid waste transfer lines. (HH Building to WD Building, T-Building to Manhole No. 5, H-Building to Manhole No. 4, and R/SW Building to WD-Building). Removal of the HH-WD line is under way.

Waste Transfer Line: Removal of radioactively contaminated underground liquid waste piping and soil has been completed. Currently awaiting shipment of LSA waste.

Building 21: This surplus building, formerly used for thorium sludge storage (4069 square feet) is scheduled for demolition.

Building 33: This building was formerly the SM Building maintenance shop and currently is used for storage of D\&D supplies (1344 square feet).

Building 38: This building, a former plutonium-238 processing facility, has been 90 percent decontaminated and the remaining ten percent currently houses a RTG fuel encapsulation line and a radioactive analytical laboratory.

Building 68: This is a D\&D material storage building (1990 square feet).

Building 102: This building provides offices for Mound's D\&D Management Engineering and Support Groups (10,928 square feet). 


\section{MOUND CERCLA OPERABLE UNITS}

Approximately 125 specific sites of releases and possible releases have been documented throughout Mound's operating history. Based on type of contaminants and geographical location, these sites have been divided into groups, called Operable Units (OUs).

Operable Unit 1 - Addresses possible chemical and radiological contamination of the Buried Valley Aquifer which underlies the southwest corner of the original Mound Plant. OU1 covers four acres on-site and includes an historic landfill, the site sanitary landfill and an overflow pond.

Operable Unit 2 - Addresses the source and pathways of possible groundwater contaminants on Mound's main hill. Tritium and volatile organic compounds are contaminants of concern. The off-site groundwater seeps on Mound's north hillside are included in this operable unit.

Operable Unit 4 - Addresses contamination in and around the Old Miami-Erie Canal. The north portion of this OU is within the Miamisburg Community Park. Contaminants of concern are Plutonium-238 and tritium.

Operable Unit 5 - Addresses on-site soil areas in the southern portions of the Mound Plant known or suspected of being contaminated by radionuclides or chemicals. Available data indicate that most of OU5 is uncontaminated. However, a number of areas within OU5 are known to be contaminated with radioactive materials, principly thorium and plutonium. The areas were contaminated by disposal of contaminated soil and debris.

Operable Unit 6 - Addresses residual contaminants from Mound's on-going Decontamination and Decommissioning (D\&D) Program which removes only radioactive contamination. OU6 ensures the conduct of CERCLA verification sampling of completed D\&D projects to document that no radioactive or hazardous contamination remains in excess of allowable CERCLA levels.

Operable Unit 9 - $\quad$ Addresses the total environmental effects of contamination attributable to the Mound Plant that may be found in the air, groundwater, soils, surface water and sediments, and includes all ecological concerns. OU9 encompasses the cumulative impact of all other OUs on-site and in the off-site environment, including characterization of possible contamination in the Buried Valley Aquifer and the plant drainage system. Presently site-wide investigations encompass the entire plant and the area within a 20 mile radius of the plant. 


\section{MOUND PLANT}

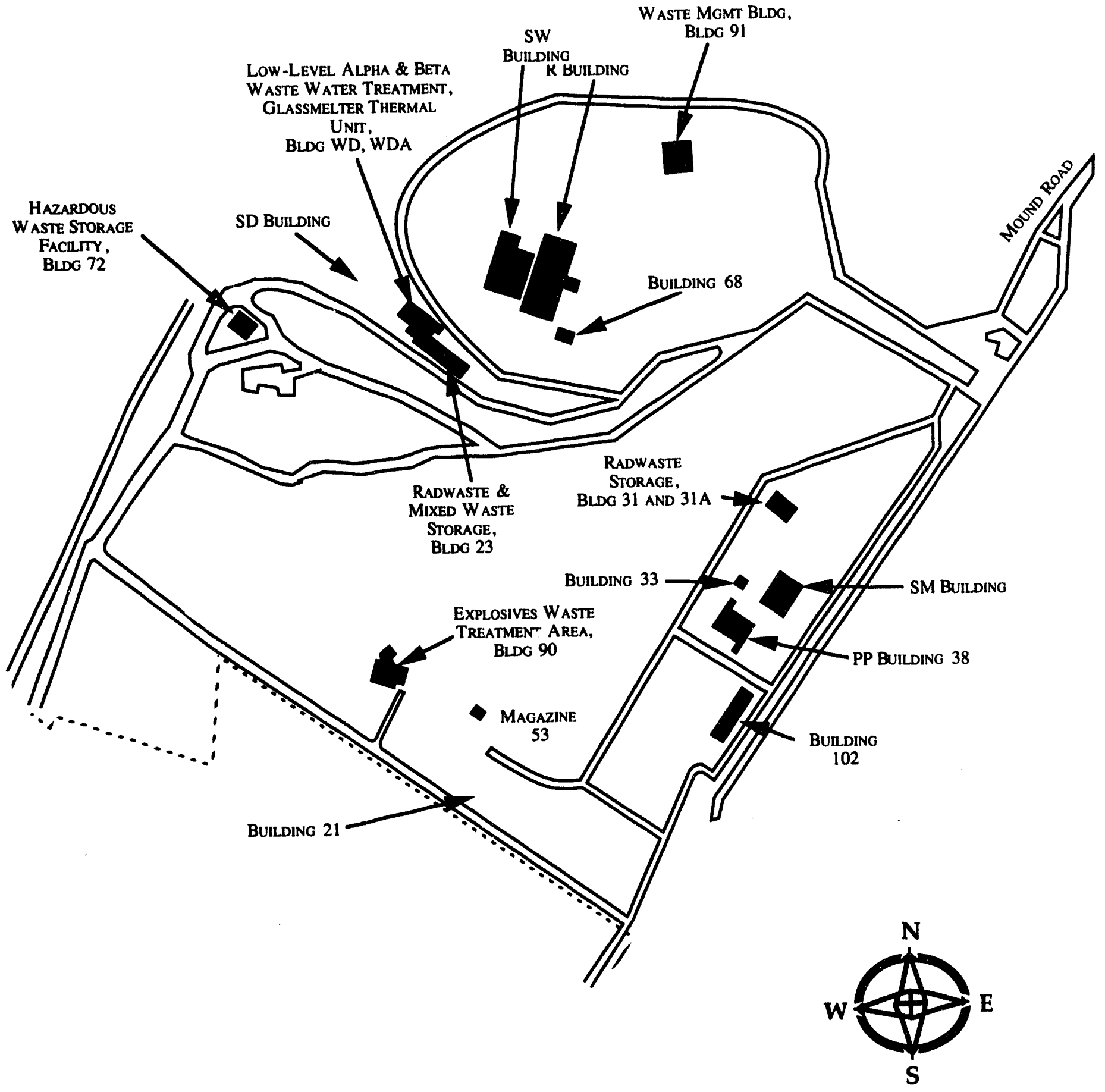




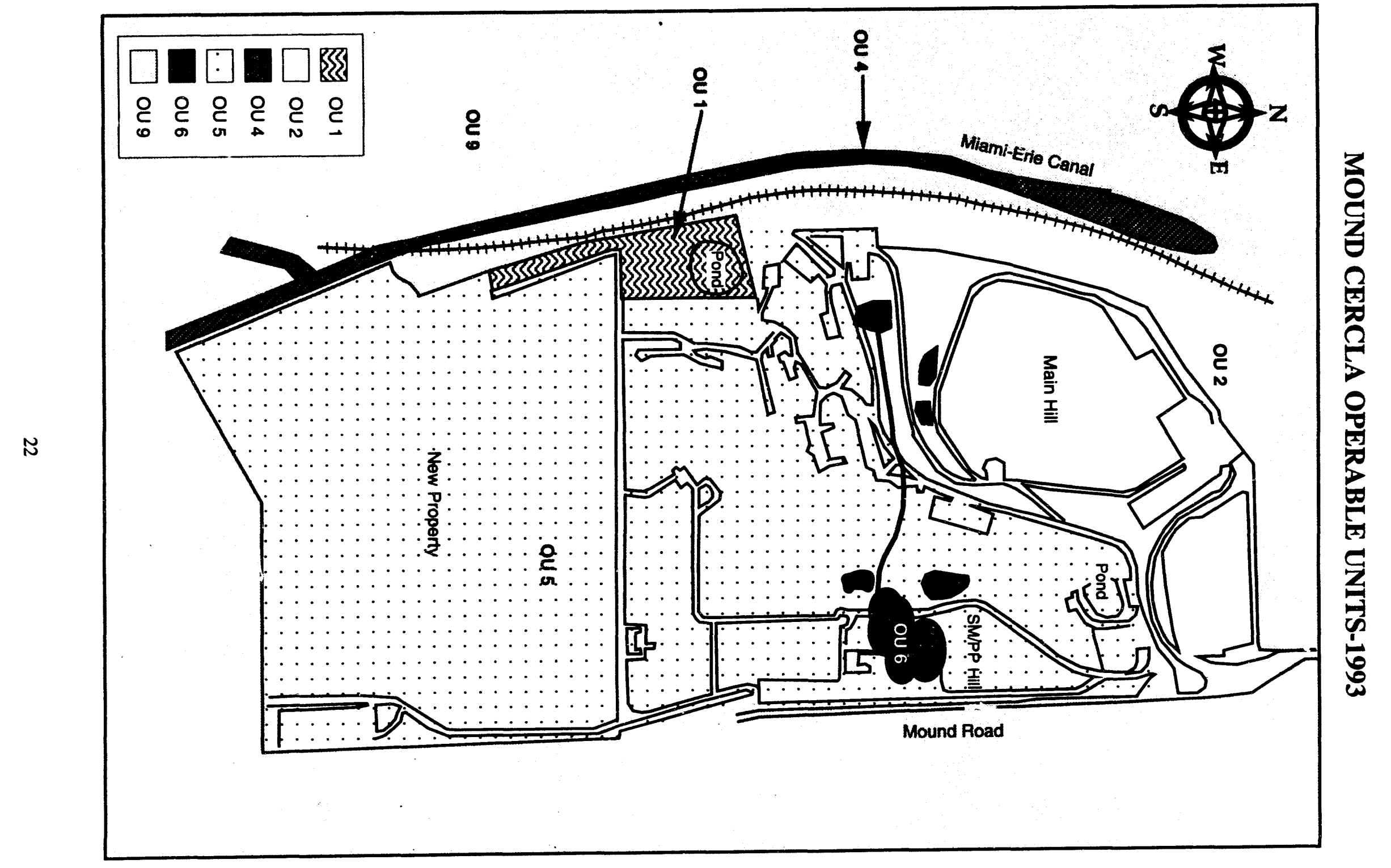




\section{PANTEX PLANT}

\section{ENVIRONMENTAI, RESTORATION AND WASTE MANAGEMENT FACILITIES}

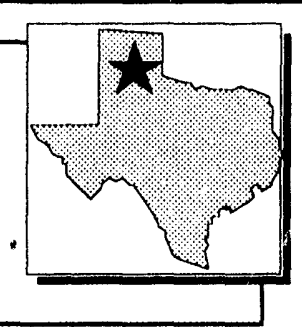

\section{DESCRIPTION}

The Pantex Plant is located in the panhandle of Texas, about 17 miles northeast of downtown Amarillo and ten miles west of the town of Fanhandle. Pantex includes a total land area of about 16,000 acres. The total population within a 50-mile radius of the plant was 259,300 in 1980 . The plant is operated to meet DOE's responsibilities for nuclear weapons assembly, stockpile monitoring, maintenance, modifications, and retirements (disassembly). Pantex conducts research and development of high explosives in support of weapons design and development and production engineering for DOE. Approximately 144 potential release sites have been identified at Pantex for investigation. Corrective activities and environmental restoration were conducted beginning in FY 1990 under the terms of RCRA Section 3008(h) Corrective Action Order of Consent and environmental restoration activities are continuing under a RCRA Part B permit jointly issued by the Texas Water Commission in April 1991 and the EPA in July 1991.

\section{AGREEMENTS}

\section{Statute/Type}

Agreement-in-Principle

RCRA Compliance Agreement

RCRA 3004(u) Permit

\section{Facilities}

Pantex Plant

Pantex Plant

Pantex Plant

\section{Parties}

DOE/TX

DOE/EPA

DOE/EPA/TX

\section{$\underline{\text { Status }}$}

Completed 7/31/90

Completed 12/10/90

Completed 4/91, 7/91

\section{FACILITIES AND PROJECTS}

\section{Waste Management Facilities:}

Burning Grounds - Numerous solid waste management units exist at the Pantex Plant Burning Grounds, including racks; an old solvent evaporation pit; a former chemical burn pit; demonstration sites; and landfills.

The outdoor burning area for high explosives (HE) includes the following sub-units:

Burning Cages - two metal mesh cages for thermal treatment of HE-contaminated, combustible solid waste.

Burning Trays - metal, sand, and fire-brick lined trays for thermal treatment of high explosives.

Burning Pads - clay pads for the thermal treatment of HE not able to be treated in burning trays.

Flashing Piss - two unlined trenches for flashing HE from metal. 
Igloo 4-50 - Storage of up to 111,300 gallons of hazardous waste in containers.

Igloo 4-19B - Now being used for Pu storage.

Igloo 4-56B - Temporary Storage of LLW in 55 gallon drums and boxes prior to shipment to Nevada Test Site for disposal.

\section{Conex Containers}

1 through 8: Storage of up to 94 cubic yards per container of hazardous solid waste.

$28,29,30,31$ : Storage of up to 94 cubic yards per container of radioactively contaminated waste.

11-7 N Pad - Concrete structure for storage of up to 33,000 gallons of hazardous waste in containers.

\section{Environmental Restoration Projects:}

Miscellaneous Chemical Spills - 16 areas where potential chemical releases may have occurred.

Landfills - 17 inactive landfills.

Fire Training Burn Pits - Two shallow, unlined burn pits formerly used by Pantex Plant firemen to ignite and extinguish fuel and/or chemical fires under a controlled environment.

Firing Sites - Seven firing sites used to test-fire configurations containing high explosives and various metals.

Cooling Tower - Former cooling tower used for cooling water from nearby HE machining operations.

Miscellaneous High Explosive/Radioactive Sites - Temporary HE burn site, a former radioactive materials staging area, and an abandoned leaching bed.

Hypalon Pond - An inactive former surface impoundment which was used to treat acid waste water from HE synthesis operations.

Ditches and Playas - Facility-wide network of man-made ditches which collect and direct rainfall runoff within closed drainage basins to one of five ephemeral lakes known as playas.

Priority Reconnaissance Sites - Five solid waste management unit groups, one area of concern, and three firing sites. All are high priority potential release sites.

Old Sewage Treatment Plant - Six sludge drying beds formerly used to treat sanitary wastes and plant operation's waste waters.

Supplemental Sites - A denuded area, three parallel depressions, an old pistol range, and several landfills.

Leaking Underground Storage Tanks - Two historic gasoline release sites.

Leaking Underground Storage Tanks at Other Locations - Five inactive tank locations requiring investigation for suspected releases. 
North Groundwater - Solid waste management unit grouping consisting of groundwater.

Wastewater Treatment - Modular unit for treatment of corrosive wastewater containing cadmium, chromium and lead; and buildings designed to treat wastewater used in the manufacture and production of High Explosive (HE) compounds and HE component parts.

\section{Future Waste Management Projects:}

Classified Waste Storage Building Project - will be designed and permitted to store containerized LLW, MW and hazardous waste in a secure area of the facility. Completion date: 10/94.

Hazardous Waste Treatment and Processing Facility Project - will be designed and permitted to treat LLW, LLMW and hazardous waste, including sanitization of metal parts and decontamination operations.

Completion date: $8 / 99$.

Hazardous Waste Staging Facility Project - will be designed and permitted to store containerized, unclassified, hazardous waste. Completion date: $6 / 94$. 


\section{PANTEX PLANT}

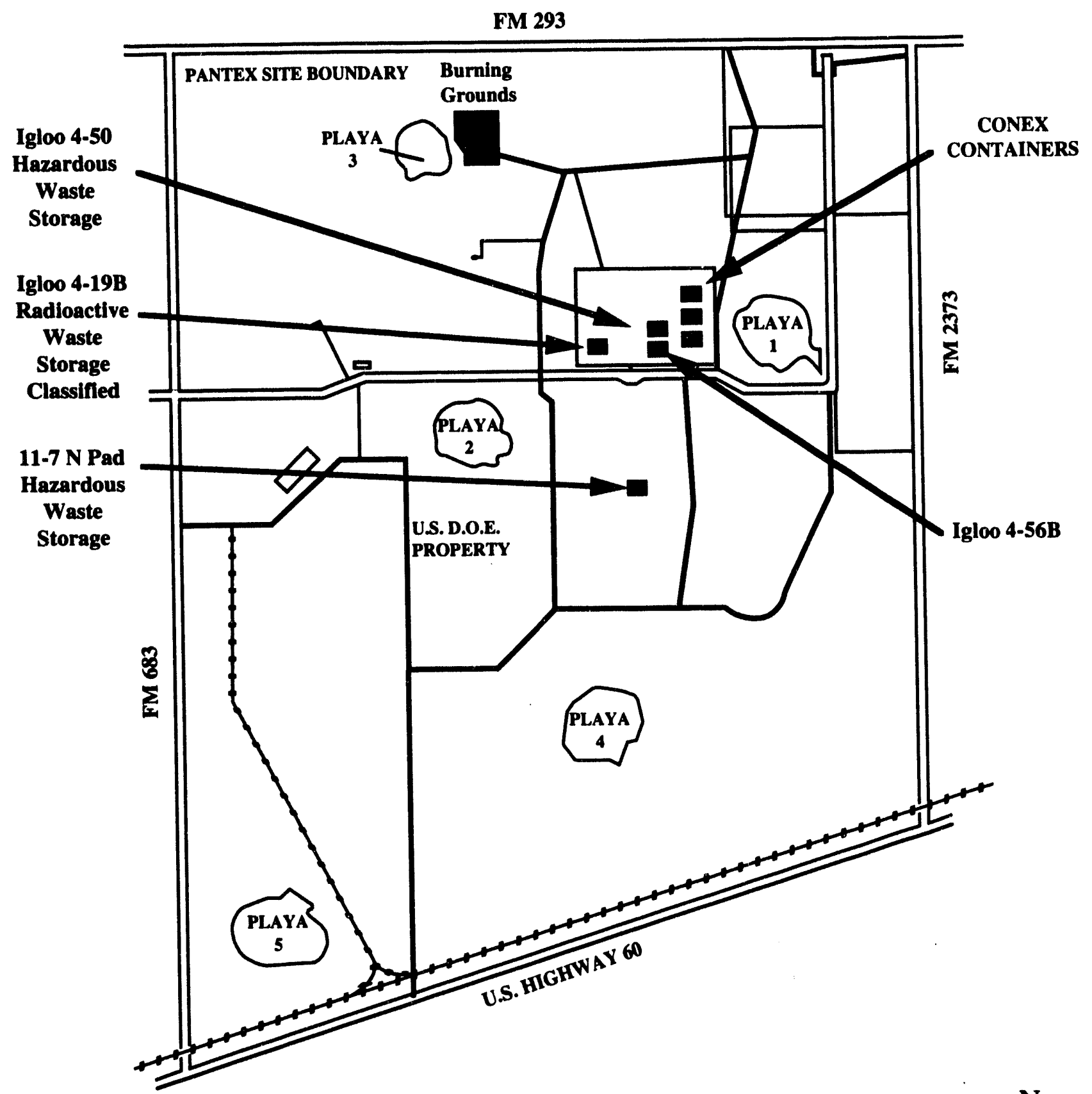

FM 293 


\section{PINELLAS PLANT}

\section{ENVIRONMENTAL RESTORATION AND WASTE MANAGEMENT FACILITIES}

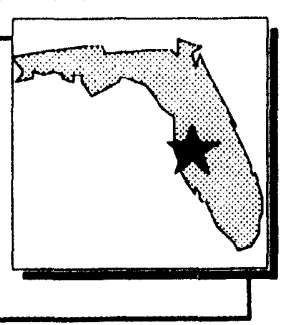

\section{DESCRIPTION}

The Pinellas Plant occupies a 99.2-acre site approximately six miles north of St. Petersburg in Pinellas County, Florida. Pinellas County is located on a peninsula bordered on the west by the Gulf of Mexico and on the east and south by Tampa Bay. The 1989 census estimated a population of 870,162 in Pinellas County. Key activities at the Pinellas Plant include the design, development, and production of special electronic and mechanical equipment for nuclear weapon applications. These products include neutron generators, specialty capacitors, thermal batteries, crystal resonators, oscillators, and clocks.

\section{AGREEMENTS}

\section{Statute/Type}

Industrial Wastewater Discharge

Permit

Hazardous Waste Operating Permit

Hazardous and Solid Waste

Amendment Permit 3004(u)

Agreement-in-Principle

\section{Facilities}

Pinellas Plant

Pinellas Plant

Pinellas Plant

Pinellas Plant
Parties

DOE/Pinellas

County

DOE/FL

DOE/EPA

$\mathrm{DOE} / \mathrm{FL}$

\section{Status}

Completed 8/28/89

Completed 1/90

Completed 2/90

Completed 9/20/90

\section{FACILITIES AND PROJECTS}

Waste Management Facilities:

Building 1000:

Building 1040:

Tank Farm:
Radioactive waste storage facility. Its capacity is approximately 100 55-gallon drums of solid LLW; 38 drums of LLMW can be stored in Bay 2, however no LLMW has been generated to date.

Hazardous waste storage facility.

Five aboveground hazardous waste storage tanks consisting of:

- Three, 5000 gallon tanks, one for storage of liquid ignitable waste, the other two are in a reserve status,

- One, 2000 gallon tank for storage of halogenated solvent waste,

- One, 500 gallon tank for storage of used oil. 
Reactive Metal Treatment:

Machine Coolant

Treatment System:

IWNE:

New Container Storage/ 90-Day Storage Facility (Bldg. 1010):
Aboveground open reaction vessel treatment facility for calcium metal, calcium bimetal, and lithium contaminated solids.

Separates heavy metal material from the machine shop coolant, allowing it to be pretreated in the Industrial Wastewater Neutralization Facility (IWNF).

Neutralizes industrial wastewater prior to discharge to the Publicly Owned Treatment Works (POTW).

Provides warehouse space for newly purchased hazardous and LLW shipping containers, and also provides storage capabilities for nonhazardous waste and new waste streams (should they be generated).

\section{Environmental Restoration Projects:}

Old Drum Storage Site:

Former Pistol Range:

Industrial Drain Leaks -Building 100:

Northeast Site including the East Pond:

\section{Incinerator Ditch:}

Diesel Fuel Spill:

Current Fire Department Training Tank:

Building 500 Spill Site:

West Pond:

Spray Irrigation Site:
Site of a storage pad, since removed, for empty drums containing waste solvents. Pad was removed in 1983.

Former small arms firing range for plant guards; removed in 1988.

Areas beneath Building 100 where potential leaks have occurred from the industrial and health physics drain system.

The Northeast Site is associated with the location of a former waste solvent staging and storage area. The East Pond received $\mathrm{pH}$-neutralized industrial waste and tertiary treated sanitary waste from 1963 to 1972 .

Ditch that formerly received incinerator scrubber water and suspected disposal of small quantities of waste solvents.

Location of diesel fuel spill that occurred in 1963.

Current location of the training tank used by plant fire department.

Former location of an oil drain associated with compressor blowdown north of Building 500. The compressor operated in Building 500 from 1964 to 1981 and was removed in 1981 .

Man-made pond that received $\mathrm{pH}$-neutralized industrial effluent and tertiary treated sanitary sewage from 197 $\varepsilon-1982$.

Land treatment site for $\mathrm{pH}$-neutralized industrial effluent and tertiary treated sanitary sewage from 1972-1982. 
Metallic Anomaly:

Trench Site:

Former Fire Department Training Tank:

Former Incineration Site:

Southwest Ditch:
Area associated with a metallic anomaly identified during an electromagnetic survey performed by the United States Geological Survey (1985).

Trenches thought to have received slurry waste from water softeners in the late 1950s.

Former location of fire training tank used by plant fire department.

Locations associated with incinerators formerly used at the Pinellas Plant.

Location of former industrial and sanitary effluent outfalls from the Pinellas Plant. The outfalls operated from the beginning of plant operations until 1968. 


\section{PINELLAS PLANT SITE LAYOUT}

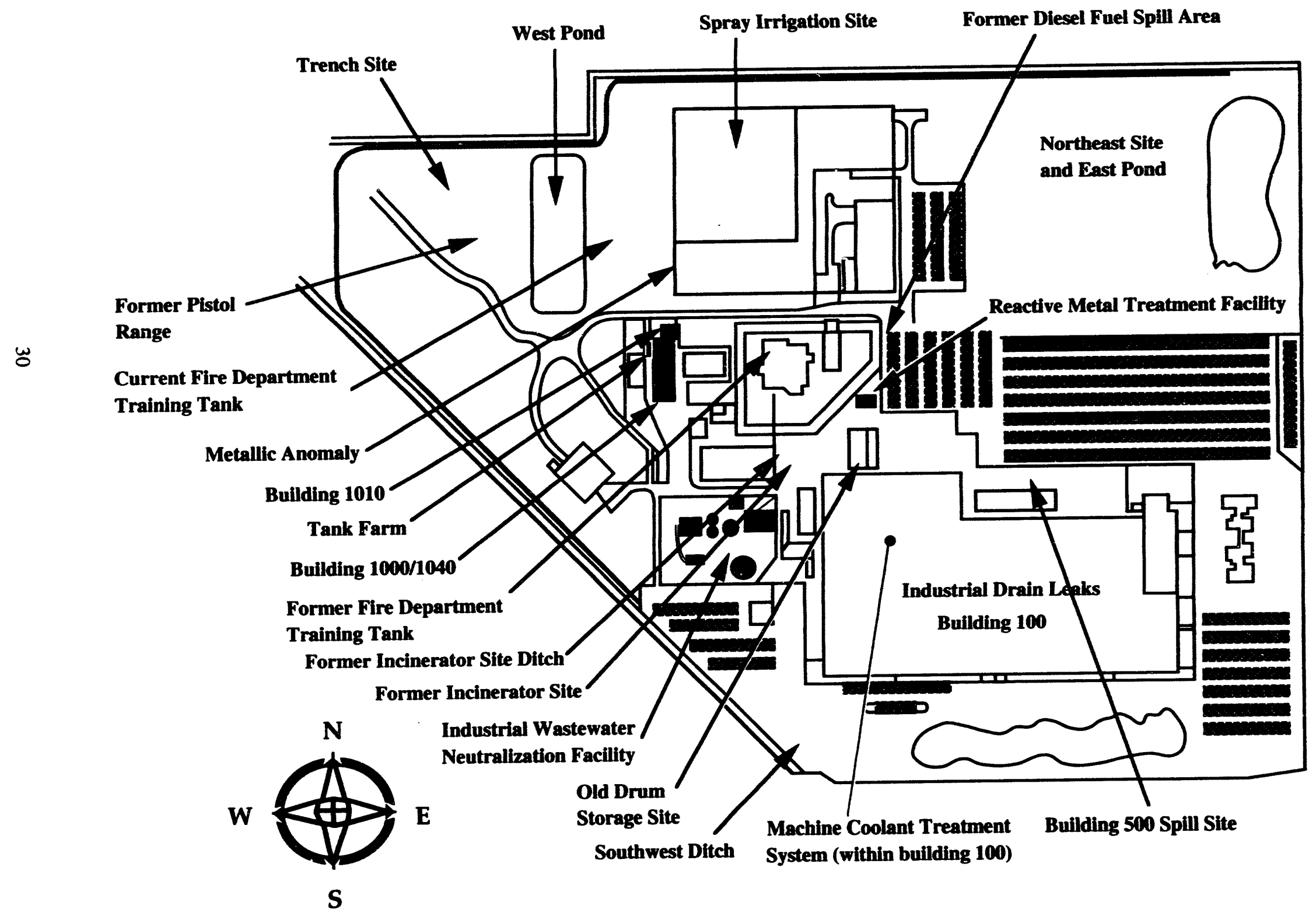




\section{SANDIA NATIONAL LABORATORIES /CALIFORNIA \\ ENVIRONMENTAL RESTORATION AND \\ WASTE MANAGEMENT FACILITIES}

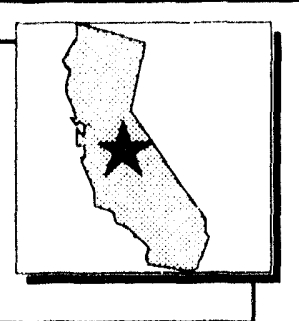

\section{DESCRIPTION}

Sandia National Laboratories/California at Livermore (SNL/CA) is located about 40 miles east of San Francisco in the Livermore Valley, approximately three miles east of the Livermore city center. SNL/CA occupies about 413 acres of land and is located only a few blocks from the edge of the city of Livermore. SNL/CA consists of research and development (R\&D) laboratories dedicated to the design and testing of nonnuclear components for nuclear weapons systems. A significant fraction of R\&D at SNL/CA is devoted to energy-related programs in the Combustion Research Facility.

\section{AGREEMENTS}

Statute/Type

California Regional Water Quality

Control Board Order 89-184

Agreement in Principle

RCRA Operating Permit
Facilities

SNL/CA

SNL/CA

SNL/CA
Parties

DOE/CA

DOE/CA

DOE/CADTSC
Status

Effective $8 / 88$

Completed 9/6/90

Effective 2/93

\section{FACILITIES AND PROJECTS}

Building 962-2: Hazardous waste storage facility.

Building 961: Radioactive and mixed waste storage facility including two compactors and other waste handling equipment.

Building 927: Classified radioactive waste storage vault.

Explosive Waste Facility designed for the disposal of energetic wastes;

Incinerator: currently undergoing Part B permitting activities. 
SANDIA NATIONAL LABORATORIES/CALIFORNIA

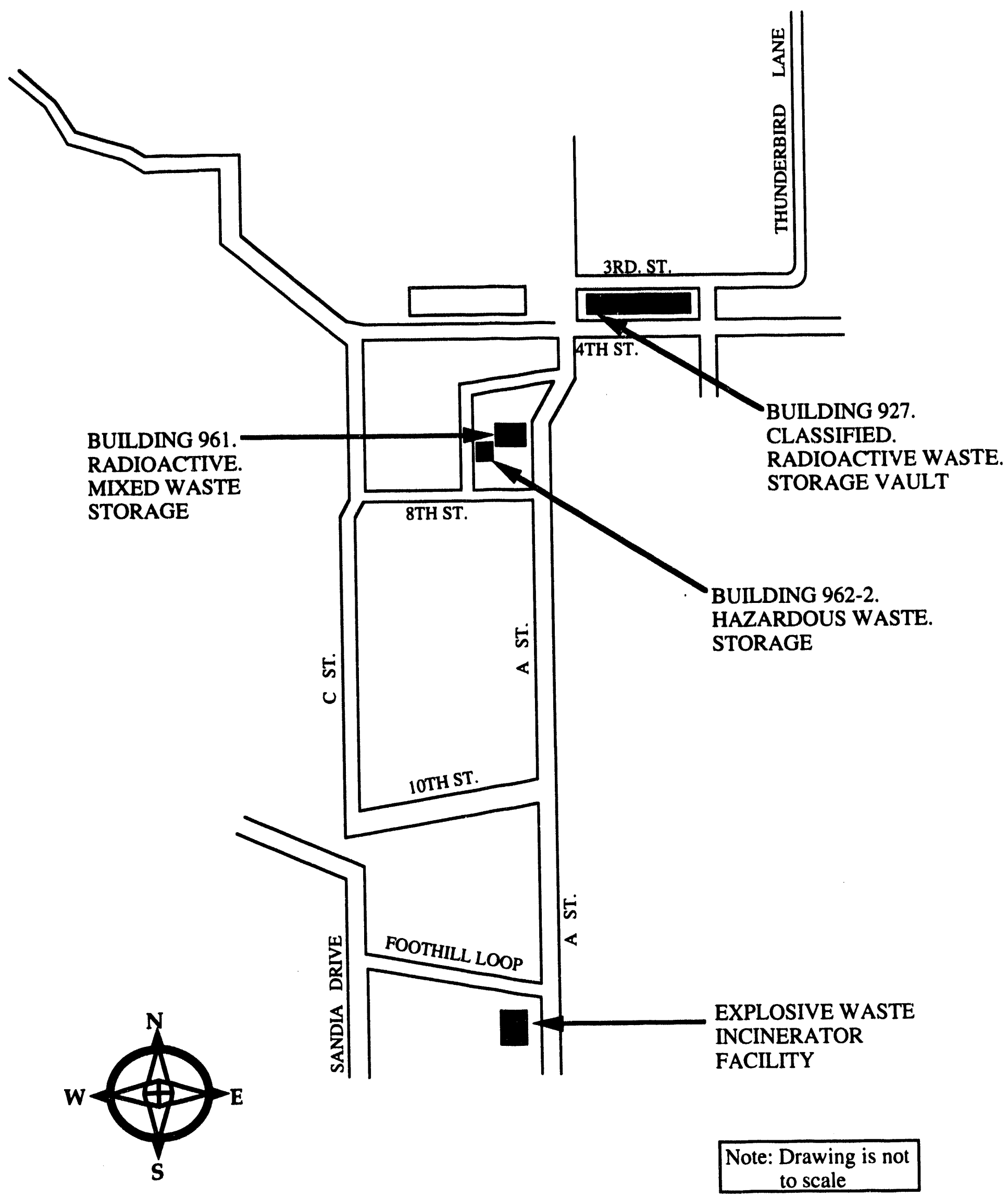




\section{SANDIA NATIONAL LABORATORIES/NEW MEXICO \\ ENVIRONMENTAL RESTORATION AND \\ WASTE MANAGEMENT FACILITIES}

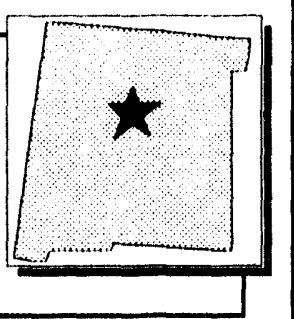

\section{DESCRIPTION}

Sandia National Laboratories/New Mexico (SNL/NM) is a research and development (R\&D) laboratory with a primary mission of development, engineering, and testing of nonnuclear components of nuclear weapons. SNL/NM's other areas of R\&D include arms control, energy, environment, and other areas of strategic importance to national security. SNL/NM occupies several parcels of land covering 2820 acres within Kirtland Air Force Base directly south of Albuquerque, New Mexico. SNL/NM is also responsible for two off-site test areas, Tonopah Test Range (TTR) and Kauai Test Facility (KTF). TTR is located in Nevada and covers 640 square miles; KTF is located in the island of Kauai within the Navy's Pacific Missile Range.

\section{AGREEMENTS}

\section{Statute/Type}

Agreement-in-Principle

RCRA Operating Permit

HSWA Module of RCRA Permit

Chemical Waste Landfill Closure Plan SNL/NM CWL

\section{Facilities}

SNL/NM

SNL/NM HWMF

SNL/NM
Parties

$\mathrm{DOE} / \mathrm{NM}$

DOE/NMED

DOE/EPA VI/

SNL/NM

DOE/NMED

\section{Status}

Completed 10/22/90

Effective $\$ / 92$

Effective 8/93

Effective 2/22/93

\section{FACILITIES AND PROJECTS}

\section{Area 1:}

Building 958/959 Hazardous Waste Management Facility: Repackaging and storage of hazardous waste.

New Building: Asbestos storage, located near Building 958/959.

\section{Area 2:}

Building 920N: PCB Storage. 
Area 3:

Environmental Restoration Landfills: Chemical waste landfill previously used for disposal of hazardous waste.

Low-level waste landfill previously used for disposal of radioactive and mixed wastes.

Building 6920 Radioactive and Mixed Waste Management Facility: Packaging, storage, and decontamination of radioactive and risixed wastes.

Building 6715: Thermal destruction facility.

Area 4:

Igloos 6000 Area: Explosive hazardous waste storage.

Area 5:

Building 6596: Mixed waste storage. 
SANDIA NATIONAL LABORATORY, NEW MEXICO

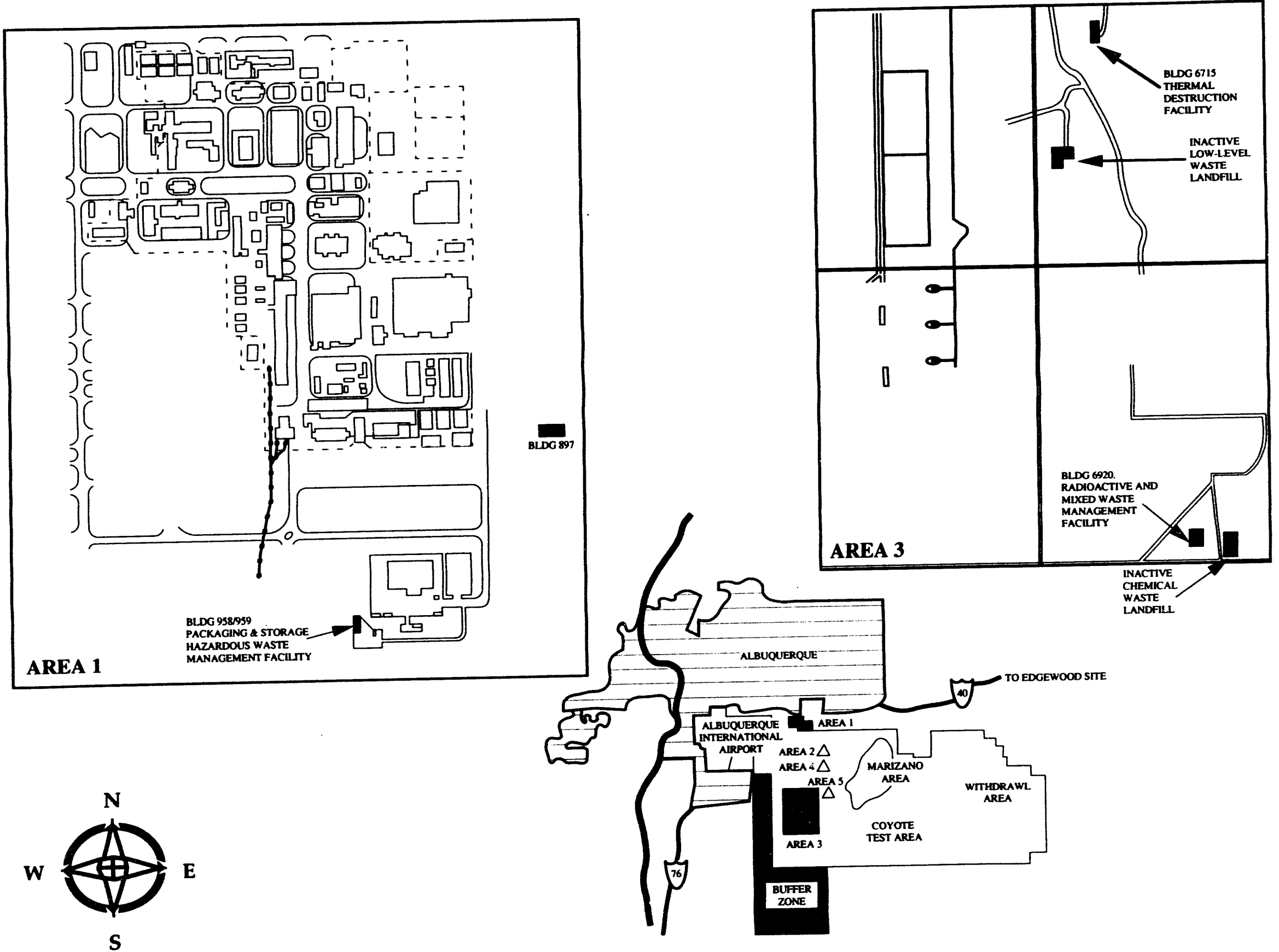




\section{SOUTH VALLEY SITE \\ ENVIRONMENTAL RESTORATION AND WASTE MANAGEMENT FACILITIES}

\section{DESCRIPTION}

The South Valley Site is the location of a facility formerly owned by the Atomic Energy Commission (AEC) and operated by ACF Industries from 1951 to 1967. From 1951 through 1967, electroplating, machining, painting, adhesives, and degreasing operations related to weapons, reactors, and space programs took place at this facility. In 1967, the U.S. Air Force took possession of the facility, which was operated by General Electric (GE) to produce jet engines. GE purchased the facility in 1984 and is the current owner.

In September 1988, EPA signed records of decision for cleanup of three operable units (OUs) in the South Valley. DOE, the U. S. Air Force (USAF) and GE were named in December 1988 as potentially responsible parties (PRPs) for two OUs: San Jose Well 6 and the GE property (Plant 83). The Record of Decision (ROD) for San Jose Well 6 called for additional studies, well abandonment, and 30 years of groundwater monitoring. The Plant 83 operable unit has volatile organic compounds (VOCs) in the soil (vadose zone), the shallow groundwater and the deep groundwater aquifers. The ROD for Plant 83 calls for additional studies, vapor extraction of solvents from the vadose zone, and pumping and treating the contaminated groundwater in the shallow and deep aquifers. DOE, USAF, and GE attempted to negotiate an agreement to fund EPA's selected remedies. Because of the failure to reach an agreement after six months, EPA issued a CERCLA 106 Unilateral Order in 1989 against GE to implement the remedies. GE is currently implementing remedial actions, and USAF and DOE are paying for approximately 91 percent of the total costs. DOE is liable for 43.2 percent of the cleanup.

\section{AGREEMENTS}

$\begin{array}{llll}\text { Statute/Type } & \text { Facility } & \text { Parties } & \text { Status } \\ \text { CERCLA Unilateral } & \text { South Valley Site, } & \text { EPA } & \text { Issued July 1989 } \\ \text { Order } 106 & \text { GE Plant 83, } & & \\ & \text { San Jose Well 6 } & & \end{array}$

\section{FACILITIES AND PROJECTS}

\section{San Jose Well 6}

This well, an Albuquerque municipal well, was closed in 1980 when investigations showed the groundwater to be contaminated with solvents. Currently, work is under way to sample the monitoring well network and other municipal and private extraction wells, and to continue the well-plugging/abandonment program. 


\section{General Electric Plant 83}

Work will continue on Plant 83 OU as required by the unilateral cleanup order issued to GE during FY 1989. As currently planned, this activity will extend, at least for monitoring activities, about 30 years. Current work activities include design of shallow zone pump and treat system, design of deep zone pump and treat system, investigating adjacent properties that may also be a source of contamination, and evaluating cleanup goals for the soil that may allow for no further soil remediation. Assessment and sampling activities are ongoing, primarily for the deep zone contamination. 


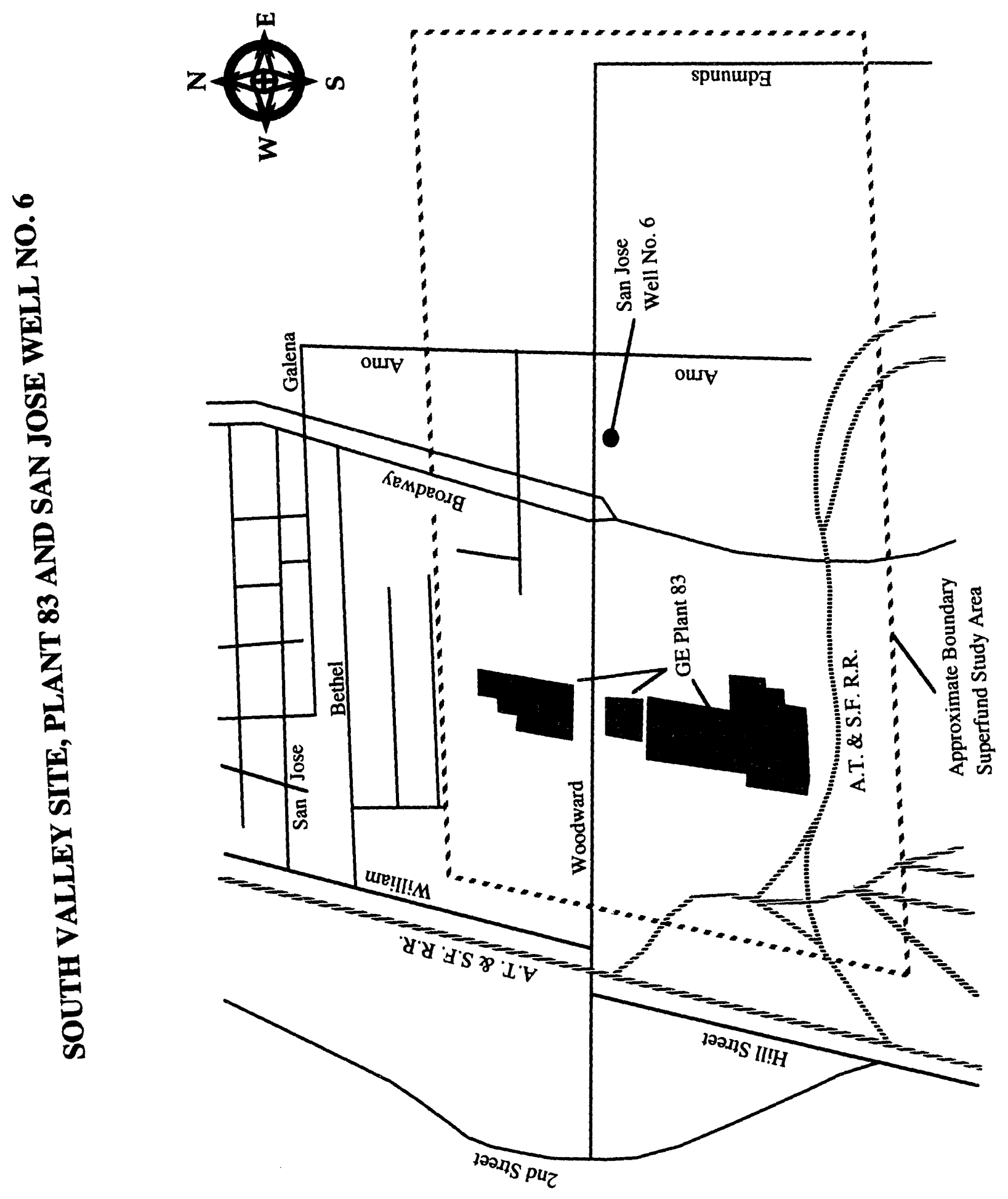




\section{URANIUM MILL TAILINGS REMEDIAL ACTION PROJECT}

\section{ENVIRONMENTAL RESTORATION AND WASTE MANAGEMENT FACILITIES}

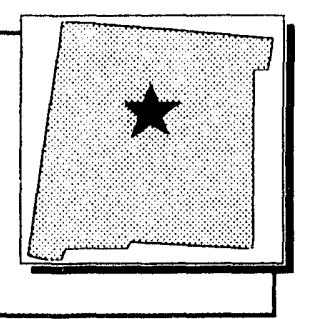

\section{DESCRIPTION}

In 1978 Congress directed DOE to remediate sandlike tailings from uranium processing located at 24 designated sites and at approximately 5000 vicinity properties in ten States and on two Indian Tribal lands. The tailings resulted from uranium production in the early 1950s through the early 1970s. The Uranium Mill Tailings Remedial Action (UMTRA) Surface Project, a Major System Acquisition Project and the UMTRA Groundwater Project, a Major Project, are treated as a single installation under the nondefense Environmental Restoration Program. Work on both projects was authorized when Congress passed the Uranium Mill Tailings Radiation Control Act (UMTRCA) of 1978, Public Law 95-604, which directed DOE to provide for stabilization and control of the uranium mill tailings from inactive sites in a safe and environmentally sound manner. The UMTRCA provides that States pay 10 percent of remedial action costs at sites within the States, while DOE pays the remaining cost. The Federal Government pays all cleanup costs for the four sites on Indian lands. The UMTRA Project Office is based in Albuquerque, New Mexico.

\section{AGREEMENTS}

1) Twelve cooperative agreements with two Indian tribes and ten states to establish responsibilities and cost sharing for remedial action at 24 cleanup sites.

2) Memorandum of Understanding with the Nuclear Regulatory Commission defining the role of the commission in oversight of the project execution.

3) Interagency agreements with the Bureau of Land Management and the U.S. Army Corps of Engineers relating to acquisition activities.

\section{FACILITIES AND PROJECTS}

\section{Ambrosia Lake, New Mexico}

The Ambrosia Lake site is located in McKinley County in northwest New Mexico approximately 25 miles north of Grants and 85 miles northwest of Albuquerque. The 2.6 million cubic yards of tailings cover 105 acres to an average height of 12 feet. Wind and water erosion has spread some of the tailings across a 570-acre area.

The Ambrosia Lake remedial action program will include cleanup of all off-site properties contaminated with tailings from the Ambrosia Lake site. These properties, called vicinity properties, are residences, commercial buildings, or open lands where tailings were used as construction materials before the potentially harmful effects of the tailings were recognized. DOE has identified three vicinity properties adjacent to the mill site where tailings were transported away from the site by wind or water erosion. Excavation and consolidation of residual radioactive materials on site started in October 1992 and will be completed in late 1995. 


\section{Belfield, North Dakota}

The Belfield site is located in southwest North Dakota, one mile southeast of the town of Belfield in Stark County. The former ashing site occupies 10.7 acres with no discernible pile remaining. The ash, produced from lignite coal that was burned in a rotary kiln, contained uranium and radium. The ash was shipped to Rifle, Colorado and Ambrosia Lake, New Mexico for further processing. Windblown stack-released ash has contaminated approximately 21 acres and requires remedial action. Approximately 58,000 cubic yards of contaminated soil and rubble are present.

Belfield vicinity property cleanup will be accomplished in conjunction with the processing site. DOE has identified eight vicinity properties for remedial action in the Belfield area.

\section{Bowman, North Dakota}

The Bowman site is approximately ten acres in size and is located in southwestern North Dakota about seven miles west of Bowman at the former Griffin siding of the Burlington Northern Railroad. The ash, produced from lignite coal that was burned in a rotary kiln, contained uranium and radium. No tailings pond or pile is present at the site because the ash product was shipped to Grants, New Mexico, for further processing. Land where windblown and stack-released ash settled became contaminated and requires remedial action. Some 128,400 cubic yards of contaminated soil and concrete rubble remain on and adjacent to the site.

The Bowman vicinity property cleanup will be accomplished in conjunction with the processing site. In Bowman, approximately 65 acres of ash-contaminated soils have been identified as needing action at this time. DOE has identified one vicinity property for remedial action in the Bowman area.

\section{Canonsburg, Pennsylvania}

The 38-acre Canonsburg site, containing more than 172,000 cubic yards of contaminated material, lies between Chartiers Creek and the ConRail tracks in the Borough of Canonsburg. It was previously known as the Canon Industrial Park. Approximately 54,000 cubic yards of contaminated material were shipped from the Canonsburg site to a nine-acre site in Burrell Township between October 1956 and January 1957. The Burrell Township site is about one mile east of Blairsville, Pennsylvania, between the Conemaugh River and the ConRail tracks. Remediation of both sites is complete (1985) and licensing is under way for both.

The Canonsburg remedial action program included cleanup of all off-site properties contaminated with tailings from the Canonsburg site. These properties, called vicinity properties, are homes, businesses, and open lands where tailings were used as construction materials before the potentially harmful effects of the tailings were recognized. DOE cleaned up 160 vicinity properties associated with the Canonsburg site. Cleanup of these properties typically consisted of transporting the contaminated materials back to the Canonsburg site for disposal with the other contaminated materials in the stabilized tailings pile.

\section{Durango, Colorado}

The former Durango uranium processing site is located just outside the city limits of Durango, La Plata County, in southwest Colorado. The site is bordered on the east by the Animas River, on the north by Lightner Creek, and on the southwest by Smelter Mountain. The designated tailings site covered about 127 acres and included two tailings piles. Prior to remedial action, the two tailings piles contained about 1.5 million cubic yards of contaminated material, and covered 10 acres of the site. The mill site and ore storage area covered about eight acres. The raffinate pond area was located nearly 0.5 miles southeast of the mill site and covered about 15 acres. 
The Durango remedial action program included cleanup of all off-site properties contaminated with tailings from the Durango site. DOE identified 129 eligible vicinity properties in the Durango area. Cleanup of these properties was initiated in 1985 and was completed in 1989. Contaminated materials from vicinity properties were transported along with the tailings remaining at the Durango site to the Bodo Canyon site for permanent disposal. The Durango remedial action was completed in 1991.

\section{Falls City, Texas}

The Falls City mill site is located in Karnes County, 46 miles southeast of San Antonio and approximately eight miles southeast of Falls City. The tailings site contains 5,764,000 cubic yards of tailings and other contaminated materials, including windblown contamination. The site consists of two parcels. Parcel A is 459 acres and contains piles $1,2,4,5$, and 7 and pond 6. Parcel B is 137 acres and contains pile 3. Parcel B is 0.9 miles east of Parcel A.

The Falls City remedial action program includes cleanup of off-site properties that have been contaminated with tailings from the Falls City processing site. DOE identified nine vicinity properties in the Falls City area. These were cleaned up in 1989, and the contaminated materials were returned to the Falls City processing site for eventual permanent stabilization with the tailings. Consolidation and stabilization of tailings at the processing site was started in early 1992, and completion of remedial action is planned for early 1994.

Grand Junction, Colorado - The Grand Junction site is located southwest of Grand Junction, Colorado on the Gunnison River. Remediation of an estimated 245,000 cubic yards of uranium mill tailings is approximately $82 \%$ complete. The companion project to clean up vicinity properties is described in the Grand Junction Project Office section of this report.

\section{Green River. Utah}

The Green River mill site and tailings pile are located in the east-central portion of Utah in Grand County. The site is one mile southeast of the City of Green River and 70 miles west of the Utah-Colorado border. Before remedial action, the tailings pile contained approximately 204,200 cubic yards of material and covered approximately ten acres to an average height of seven feet.

Cleanup of the Green River vicinity properties was accomplished in conjunction with the processing site cleanup. DOE identified 17 vicinity properties in the Green River area. Vicinity property remedial action consisted of removing the contaminated materials from the vicinity properties and transporting them back to the disposal site. Approximately 39,300 cubic yards of vicinity property contaminated material were included in the disposal. Remedial action was completed in 1989.

\section{Gunnison, Colorado}

The Gunnison mill site is a 61 -acre tract located southwest of the city of Gunnison and adjacent to the Gunnison airport. The 720,000 cubic yards of tailings cover an area of about 35 acres with a maximum height of 13 feet.

The city and the site are located in the valley of the Gunnison River at an elevation of 7600 feet and are surrounded by mountains rising to 12,000 feet. The old mill building and two other structures remain at the site.

DOE has identified 11 vicinity properties in the Gunnison area. Cleanup of these properties will typically consist of removing the contaminated materials to the final disposal site for permanent stabilization. Surface remedial action of the processing site was started in 1992. 


\section{Lakeview, Oregon}

The Lakeview mill site and tailir gs pile were located in south-central Oregon approximately 16 miles north of the California-Oregon border and 96 miles east of Klamath Falls, Oregon. The tailings pile covered some 30 acres of the 258-acre site and contained 940,000 cubic yards of contaminated material. Six evaporation ponds occupied another 64 acres. Remedial action began in June 1986 and was completed in October 1989. The remedial action involved relocating the residual radioactive material to the Collins Ranch disposal site approximately 7 miles northwest of Lakeview.

DOE identified eight vicinity properties in the Lakeview area. Cleanup of the Lakeview vicinity properties started in May 1987 and was completed in August 1988 in conjunction with the processing site.

\section{Lowman. Idaho}

The Lowman mill site is located in Boise County approximately 75 miles northeast of Boise, Idaho, in the Boise National Forest. The town of Lowman is 0.5 mile southwest of the site, which occupies 35 acres. Piles of radioactive sand were scattered over the site, covering approximately 10.1 acres and contain approximately 62,200 cubic yards of tailings. Little remains of the mill structures except foundations and debris. Other contaminated areas on the site include the mill yards, ore storage area, evaporation ponds, and windborne and waterborne contaminated material. The total amount of contaminated material on-site is about 90,980 cubic yards. The remedial action was completed in 1992.

Lowman vicinity property cleanup was accomplished in conjunction with the processing site. In Lowman, 34 vicinity properties required remedial action. The contaminated material from the vicinity properties was stabilized with other materials at the Lowman site. Vicinity property remedial action began in 1990 and was completed in 1991 . These properties contained an estimated 38,700 cubic yards of contaminated material.

\section{Maybell, Colorado}

The Maybell mill site and tailings pile cover 124 acres and are located approximately 25 miles west of the town of Craig, in Moffat County in northwestern Colorado. The site is five miles northeast of the town of Maybell. Several open pit mines surround the site. An additional 182 acres of land contain contamination deposited by wind or water erosion from the site. The total estimated volume of contaminated material at the site is $3,290,000$ cubic yards. Remedial action is scheduled to begin in 1995.

\section{Mexican Hat, Utah}

The Mexican Hat site covers 235 acres and is located at Halchita, Utah, on Navajo Nation land, about 1.5 miles southwest of Mexican Hat, Utah.

Prior to the start of remedial action, there were two adjacent tailings piles covering 69 acres and containing 2.5 million cubic yards of tailings. Windblown and waterborne contamination on and off the site covered about 162 acres with an estimated volume of 266,500 cubic yards. An additional 19 acres was contaminated in the former ore storage and mill yard areas. The total volume of contaminated material is 2.7 million cubic yards.

The Mexican Hat remedial action program includes cleanup of off-site properties contaminated with tailings from the Mexican Hat site. There are 11 vicinity properties associated with the Mexican Hat site. 


\section{Monument Valley, Arizona}

The Monument Valley site is on Navajo Nation land 13 miles east of Monument Valley Tribal Park, in Arizona. It is located 17 miles south of the Mexican Hat site and is about five miles south of the Utah-Arizona border.

The site covers approximately 98 acres. The tailings are located in two piles covering about 28 acres. The old heap-leach pile covers about 11 acres to an average height of 11 feet and contains 192,500 cubic yards of material. The new tailings pile is cone-shaped and about 65 feet high. It covers about 17 acres and contains 650,100 cubic yards, or approximately 66 percent of the total volume of tailings and contaminated materials at the site. The remaining windblown and contaminated materials on-site cover about 55 acres and contain 140,700 cubic yards of material. Little remains at the site except tailings and rubble.

There are three vicinity properties at the Monument Valley site. Contaminated material from these properties is being transported to the Mexican Hat disposal site along with other contaminated material from the Monument Valley site.

\section{Naturita, Colorado}

The former mill site is located two miles northwest of the town of Naturita, Montrose County, Colorado. The tailings were removed by a previous owner; however, the 50-acre site contains approximately 430,000 cubic yards of material with residual radioactive contamination. An additional 85 acres adjacent to the site are contaminated with 145,000 cubic yards of contaminated windblown material.

DOE identified 20 vicinity properties in the Naturita area. There are no tailings at the mill site; however, cleanup will include contaminated materials and demolition debris from the mill site area. Cleanup of the vicinity properties typically consists of removing the contaminated materials to the final disposal site for permanent stabilization.

\section{Rifle, Colorado}

The inactive uranium processing sites at Rifle lie in the Colorado River valley near the city of Rifle. The sites are about two miles apart and are referred to as the Old Rifle and New Rifle sites.

Old Rifle is a 22-acre site with a tailings pile containing approximately 333,000 cubic yards of material. It covers approximately 13 acres of land and has an additional total volume of 96,000 cubic yards of windblown contaminated material and 168,000 cubic yards of contaminated soils beneath the pile. Old Rifle is just east of the Rifle city limits in Garfield County, Colorado. It is bounded by U.S. Highway 24 on the north and the Denver and Rio Grande Western Railroad tracks on the south. The Colorado River is immediately south of the railroad tracks.

The 142-acre New Rifle site is west of the city of Rifle. It is bordered on the north by the Denver and Rio Grande Western Railroad tracks, on the south by Interstate 70, and on the east by the Colorado River. The tailings pile contains approximately $2,415,000$ cubic yards of tailings covering about 33 acres and has very steep side slopes rising to a height of about 55 feet. An additional 442,000 cubic yards of windblown contaminated materials and 375,000 cubic yards of subpile contaminants are also present on the New Rifle site.

DOE has identified 94 vicinity properties for remedial action in the Rifle area. Cleanup of residential facility properties began in April 1989. The remaining vicinity properties associat @d with the processing site are being remediated with the main remedial action work which began in 1992. Contaminated materials from vicinity properties are typically removed from the property and stored at the New Rifle site for eventual permanent disposal at the East Gulch site. 


\section{Riverton, Wyoming}

The Riverton mill site and tailings pile were both located about 2.5 miles southwest of the center of Riverton on the north side of State Highway 138 (formerly State Highway 789) in Fremont County, Wyoming. The total processing site occupied 170 acres. Before remedial action, the tailings pile occupied about 72 acres and contained 900,000 cubic yards of material at an average height of four feet. The pile was covered with 18 inches of fill material. Site remedial action began in May 1988 and was completed in September 1990. The cleanup involved relocating the residual radioactive material to the Gas Hills UMETCO Title II site.

DOE identified 41 vicinity properties in the Riverton area. Cleanup of these properties was initiated in 1985 and concluded in 1990. Contaminated materials from vicinity properties were transported along with the tailings remaining at the Susquehanna-Westem site to the UMETCO facility in the Gas Hills.

\section{Salt Lake City, Utah}

The 128-acre Salt Lake City site, known as the Vitro site, contained approximately 2.7 million cubic yards of tailings and other materials. It is located about four miles south-southwest of the center of Salt Lake City. An ore-processing mill and ore storage and transportation facilities were located on eight acres on the eastern portion of the site. Tailings occupied the remaining 120 acres in piles up to $16 \mathrm{feet}$ in height. The tailings were relocated to the Clive disposal site west of Salt Lake City, and remedial actions were completed in 1989.

DOE identified 118 vicinity properties in the Salt Lake City area. Remedial action, consisting of removing the contaminated material from the vicinity properties and stabilizing it at the disposal site, was completed in 1987.

\section{Shiprock. New Mexico}

The Shiprock site is located on a 144-acre tract of land on the Navajo Nation, south of the San Juan River and adjacent to the town of Shiprock. The tailings were located in two adjacent piles covering approximately 72 acres and containing 1.9 million cubic yards of tailings and contaminated rubble and soil. The north pile covered 26 acres and varied in height from 14 to 40 feet. The south pile covered 46 acres and was approximately 15 feet in height. The former raffinate pond area and a few buildings were located to the west of the piles. The site is about 4960 feet above sea level, and the surrounding country is arid and desert-like with low hills, steep mesas, and sparse vegetation. Remedial action was completed in 1986.

Fifteen vicinity property sites required remedial action. Cleanup of the Shiprock vicinity properties was accomplished in conjunction with the processing site. This remedial action consisted of removing the contaminated materials from the vicinity properties and disposing of them with the mill site tailings.

\section{Spook Site, Wyoming}

The Converse County mill site and tailings pile, called the Spook site, are located approximately 48 miles northeast of Casper in Converse County and 32 miles northeast of Glenrock, Wyoming. The site covers about 55 acres. The 240,000 cubic yards of tailings occupied about five acres mostly in an open pit mine which was 100 feet deep at its deepest point. The Spook remedial action program was a joint effort between the DOE UMTRA project and the Wyoming Abandoned Mine Lands Program. Residual radioactive material was stabilized in an inactive open mine pit on the site and the remedial action was completed in 1989.

Cleanup of the one Spook vicinity property was completed in conjunction with the site work. 


\section{Slick Rock. Colorado}

There are two sites at Slick Rock: the Union Carbide Corporation site (UC site) and the Old North Continent site (NC site). These two sites are about one mile apart, and are located three miles northwest of the Post Office at Slick Rock, nine miles east of the Colorado-Utah border, and 25 miles north of Dove Creek, Colorado. The sites are in the Dolores River Valley.

DOE has identified four vicinity properties in the Slick Rock area. Cleanup of three properties will consist of removing the contaminated materials and disposing of them at the preferred disposal site.

The UC site contains approximately 533,400 cubic yards of tailings on 93 acres. The NC site and assorted contaminated lands cover 43 acres with approximately 781,300 cubic yards of tailings. No buildings or foundations remain on either site. The DOE is proposing to relocate the residual radioactive material to the nearby Burro Canyon site.

\section{Tuba City Arizona}

The Tuba City site is located on part of the Bennett-Freeze District land, currently under dispute between the Navajo Nation and the Hopi Tribe. The site is $\mathbf{5 . 5}$ miles east of Tuba City in Coconino County, Arizona, and 85 miles north of Flagstaff.

The site contained about 800,000 cubic yards of material on 105 acres, of which 22 acres were covered by the tailings pile, 44 acres were former evaporation ponds, and the remaining acres were a result of windblown contamination. Remedial action was completed in 1990.

DOE has identified one vicinity property associated with the Tuba City site. Contaminated materials from the vicinity property were transported back to the tailings site for permanent disposal. 


\section{UMTRA SITE LOCATIONS}

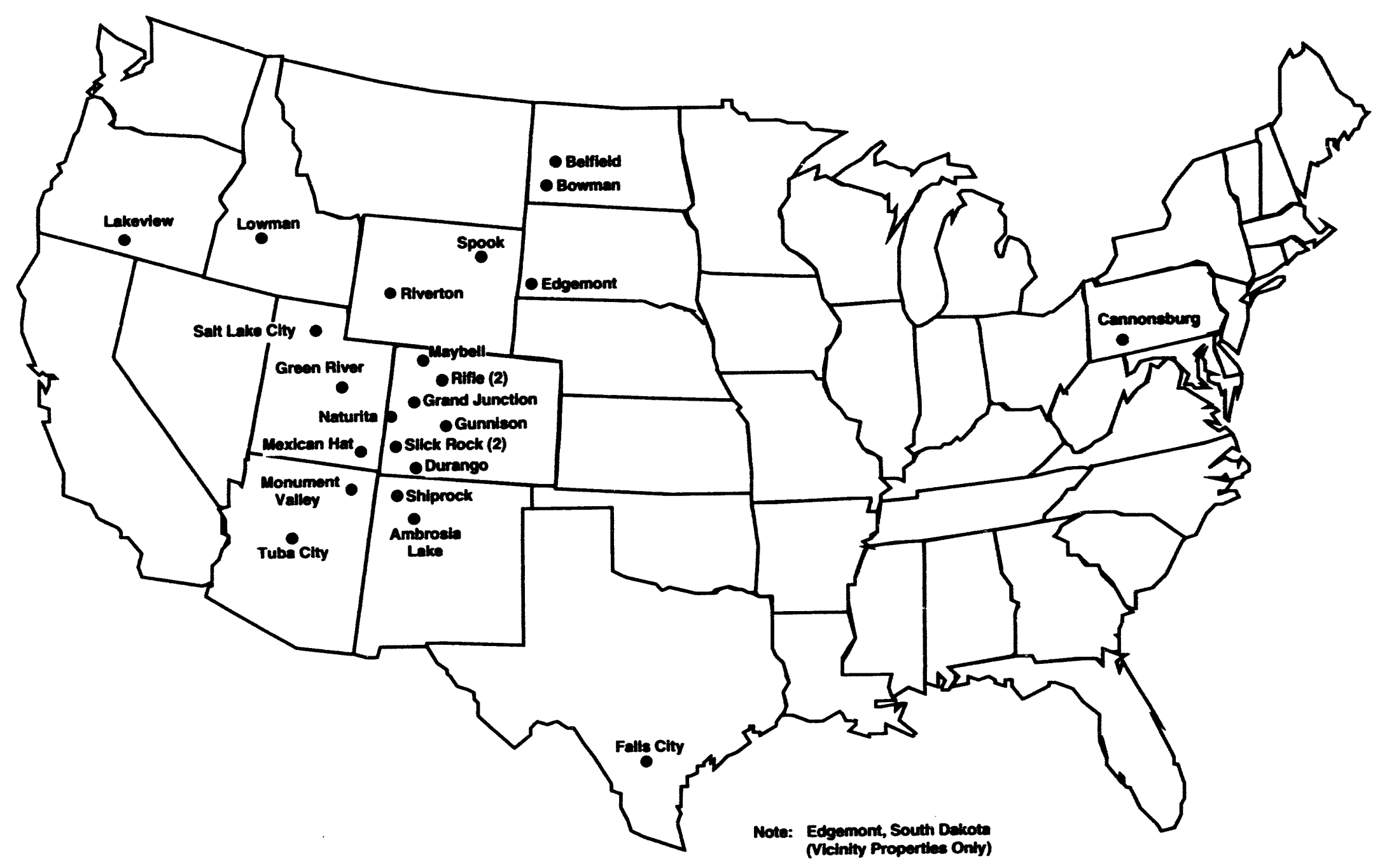




\section{WASTE ISOLATION PILOT PLANT}

\section{ENVIRONMENTAL RESTORATION AND WASTE MANAGEMENT FACILITIES}

\section{DESCRIPTION}

The Waste Isolation Pilot Plant (WIPP), located 26 miles east of Carlsbad, New Mexico, is a research and development facility with the mission of demonstrating the safe disposal of radioactive transuranic (TRU) waste resulting from U.S. defense activities and programs. The site is located on 16 square miles of land, with development plans for 2.27 square miles in the center of the site. Adequate space exists for present missions and future expansion, if required. WIPP is essential to solving the growing problems of how to safely and efficiently dispose of radioactive waste in an environmentally sound manner.

The WIPP mission can be described as comprising three major programs:

1. Provide permanent geological disposal of defense-generated transuranic (TRU) waste.

2. Provide facilities where experiments can be conducted to extend the understanding of geological nuclear waste disposal in salt.

3. Provide a contact-handled $(\mathrm{CH})$ and remote-handled (RH) TRU waste transportation fleet.

\section{AGREEMENTS}

Stipulated Agreement on Civil Action No. 81-0373 JB - This agreement, approved by the U.S. District Court was executed on July 1, 1981. The agreement assures that a binding, enforceable "consultation and cooperation" agreement will be entered into by DOE and the State and that DOE will make a "good faith effort" to resolve certain State off-site governmental concerns. The Stipulated Agreement also addresses a number of additional studies and experiments to be conducted by DOE for the Site Preliminary and Design Validation phase of the WIPP facility.

Agreement for Consultation and Cooperation - Usually referred to as the "C\&C Agreement," this agreement is contained in Appendix A to the Stipulated Agreement. It affirms the intent of the Secretary of Energy to consult and cooperate with New Mexico with respect to State public health and safety concerns.

Working Agreement for Consultation and Cooperation. Appendix B. Article IV. Revision I - This agreement, Appendix B to the Stipulated Agreement, identifies in Article IV over 11 "key events" and "milestones" in the construction and operation of the WIPP facility that must be reviewed by the State before they are commenced. Many environmental items are included.

Supplemental Stipulated Agreement Resolving Certain State Off-Site Concems Over WIPP - This agreement, dated December 27, 1992, addresses five State concerns including the need for State "verification" of the WIPP Environmental Monitoring Program. The concerns addressed are: State liability (for a nuclear incident), emergency response preparedness, transportation monitoring of the WIPP facility waste, the WIPP facility environmental monitoring by the State, and upgrading of State highways. 
Eirst Modification to the July 1.1981. Agreement for Consultation and Cooperation on WIPP by the State of New Mexice and the U.S. Department of Energy - This modification was signed November 30, 1984, wherein DOE and the State agree to address certain concerns of the State regarding: (1) the specific mission of the WIPP Project, (2) a demonstration of retrievability prior to waste emplacement, (3) post-closure control and responsibility, (4) completion of certain additional scientific testing and reports, (5) compliance with applicable Federal regulatory standards for waste repositories, and (6) a program for encouraging and reporting on the hiring of New Mexico residents at the WIPP Project.

Second Modification to the July 1.1981. Agreement for Consultation and Cooperation on WIPP by the State of New Mexico and the U.S. Department of Energy - Signed A rrust 4, 1987, wherein DOE and the State agree to address certain concerns of the State regarding: (1) surface and subsurface mining and drilling after closure of the WIPP site; (2) the disposal of salt tailings at the WIPP site; and (3) compliance with U.S. Environmental Protection Agency, U.S. Department of Transportation, and U.S. Nuclear Regulatory Commission regulations.

Environmental Oversight and Monitoring Agreement - This agreement states that DOE will provide additional technical and financial support for State activities in environmental oversight, monitoring, access, and emergency response to ensure compliance with applicable Federal, State, and local laws at several DOE facilities including the WIPP facility.

\section{FACILITIES AND PROJECTS}

The total gross permanent building square footage required to support the WIPP mission is 407,162 square feet. As of September 30,1992, the existing gross permanent building square footage is 287,423 square feet.

Permanent office space of 97,500 square feet will be needed for approximately 800 personnel. As of September 30,1992, 93,500 square feet of adjusted office space exists. Of this total 60,300 square feet are permanent and 33,200 square feet are temporary or leased.

Permanent storage space of 69,000 square feet is needed to support the WIPP mission. As of September 30, 1992, 37,800 square feet of storage exist.

The Training Building is a FY 1992 GPP construction project scheduled for completion in FY 1994. This 10,000 square foot facility will provide adequate on-site classroom facilities with mock-up capabilities for maintenance training.

One line item project is scheduled for a FY 1995 start, the Installation of Permanent Electrical Service for the WIPP. This line item project will provide adequate capacity and eliminate the impact of single contingency outages, thereby significantly improving the quality of the WIPP's electrical power supply.

Line item projects scheduled for FY 1997 starts are the Technology Research and Development Center, and the Administration Building. The 35,000 square foot Technology Research and Development Center will provide permanent consolidated facilities for the on-site scientific advisor. SNL personnel are currently housed in 13 temporary trailer facilities. This facility will include warehouse, administration, and laboratory space, allowing for the removal of all temporary SNL trailers. The 40,000 square foot Administration Building will consolidate and centrally locate an estimated seven groups that are currently scattered throughout the site. This building will allow the removal of approximately 15 temporary trailers, and allow groups currently located in town to be moved to the site. 
The line item scheduled for a FY 1998 start is the Maintenance Building. The 25,000 square foot Maintenance Building will consist of approximately 20,000 square feet of floor space for maintenance activities including areas for vehicle service, welding, instrumentation calibration, electrical equipment service and repair, and a personnel change area. Approximately 5,000 square feet will be an administrative area for maintenance support personnel.

The WIPP Project Records Center is a scheduled FY 1995 GPP construction project. The facility will consist of approximately 8,000 square feet for records storage and records administrative personnel. This project will allow the permanent records to be stored at the WIPP site.

Expanding the parking lot is scheduled FY 1995 GPP construction project. The expansion will accomodate the vehicles for the future projected site population.

The Port-A-Camp Storage Building is a scheduled FY 1994 GPP construction project. This 15,000 square foot facility will allow spare parts (e.g., waste hoist ropes) to be properly stored in a designated area. This facility will also allow re-usable materials, currently stored outside, to be environmentally protected.

Under this plan, the WIPP will be fully developed by September 30, 1999.

The following is list of permanent buildings on the WIPP Site:

\section{DESCRIPTION}

Effluent Monitoring Instrument Shed A

Effluent Monitoring Instrument Shed B

Waste Handling Building

TRUPAC Maintenance Building

Exhaust Shaft Filter Building

Monitoring Station A

Monitoring Station B

Water Chiller Facility

Support Building

Safety and Emergency Services Facilities

Warehouse/Shops

Vehicle Service Building

Auxiliary Warehouse/Maintenance

Water Pumphouse

Guard and Security Building

Core Storage Building

Maintenance Storage

Compressor Building

Telephone Hut

Armory Building

Gatehouse

Exhaust Shaft Hoist Equipment Warehouse

Sullair Compressor Building

Engineering Building Offices

\section{BUILDING NO.}

364

365

411

412

413

$413 \mathrm{~A}$

$413 \mathrm{~B}$

414

451

452

453

454

455

456

458

459

461

463

468

473

475

482

485

486 


\section{WASTE ISOLATION PILOT PLANT BUILDING LAYOUT}

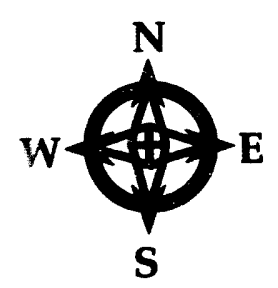

Technology Research and

Project Records Center

Install Permanent

/ Development Center FY 1995 GPP Electrical Service FY 1997 LIP 3

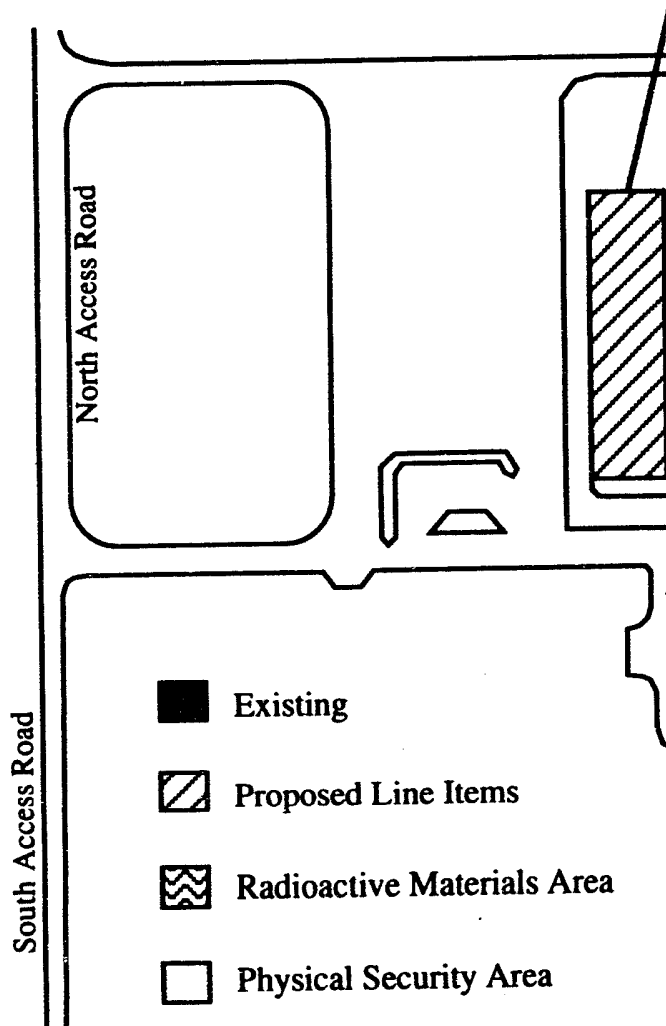
imioning

站

Physical Security Area

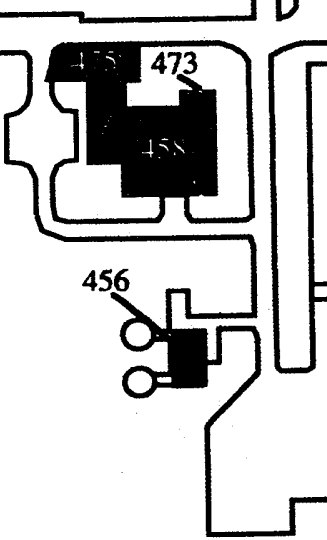

Maintenance Facility FY 1997 LIP 5

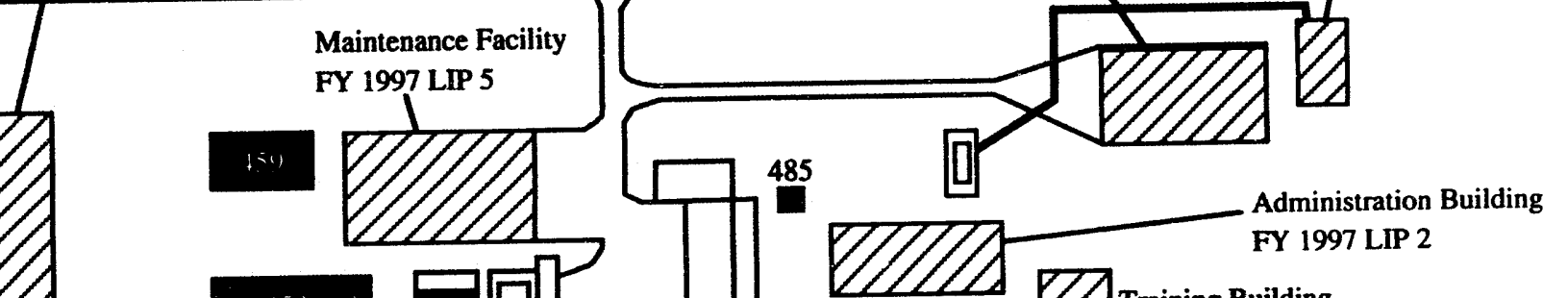




\section{WASTE ISOLATION PILOT PLANT \\ SURFACE FACILITIES}

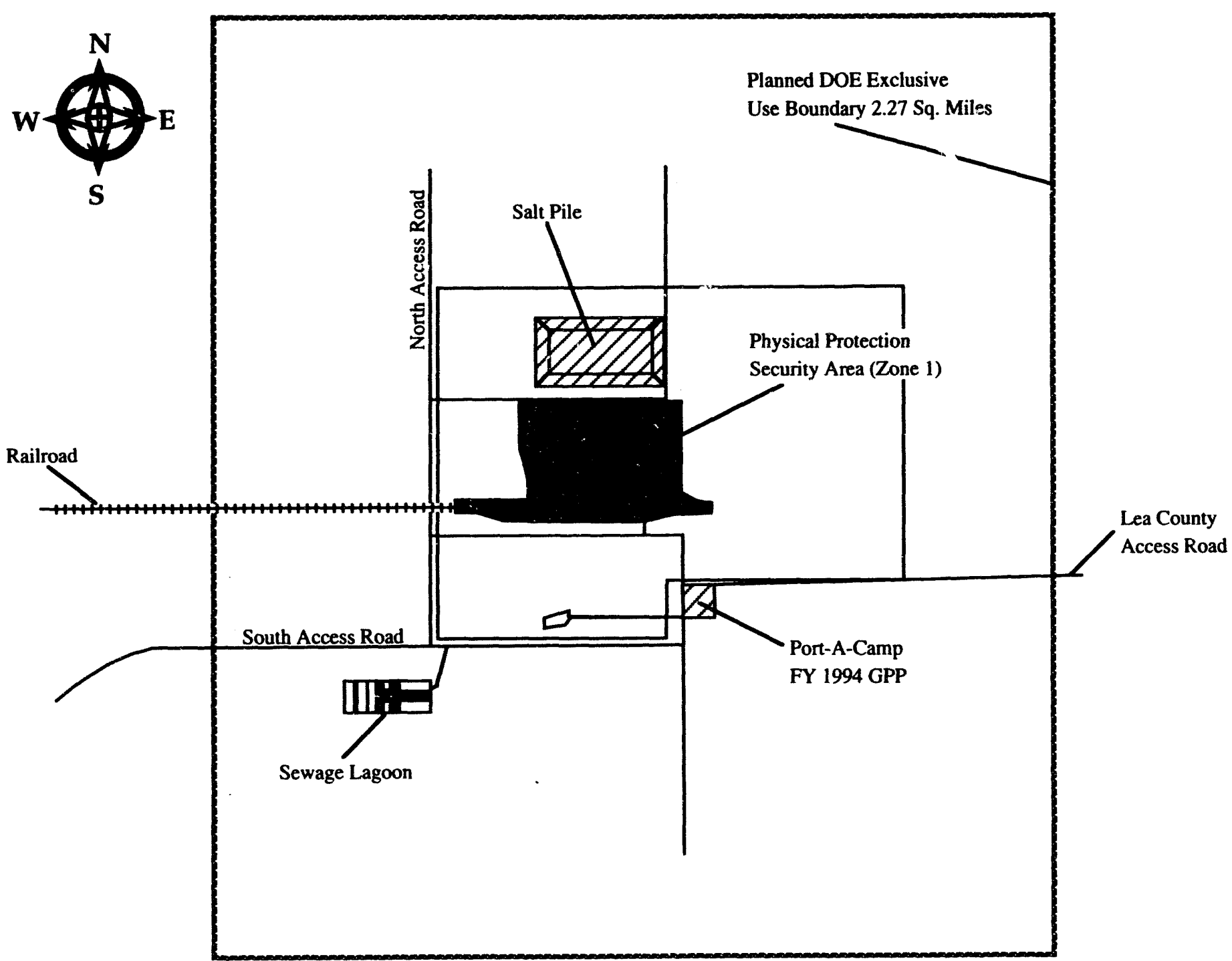




\section{WASTE ISOLATION PILOT PLANT UNDERGROUND FACILITIES}
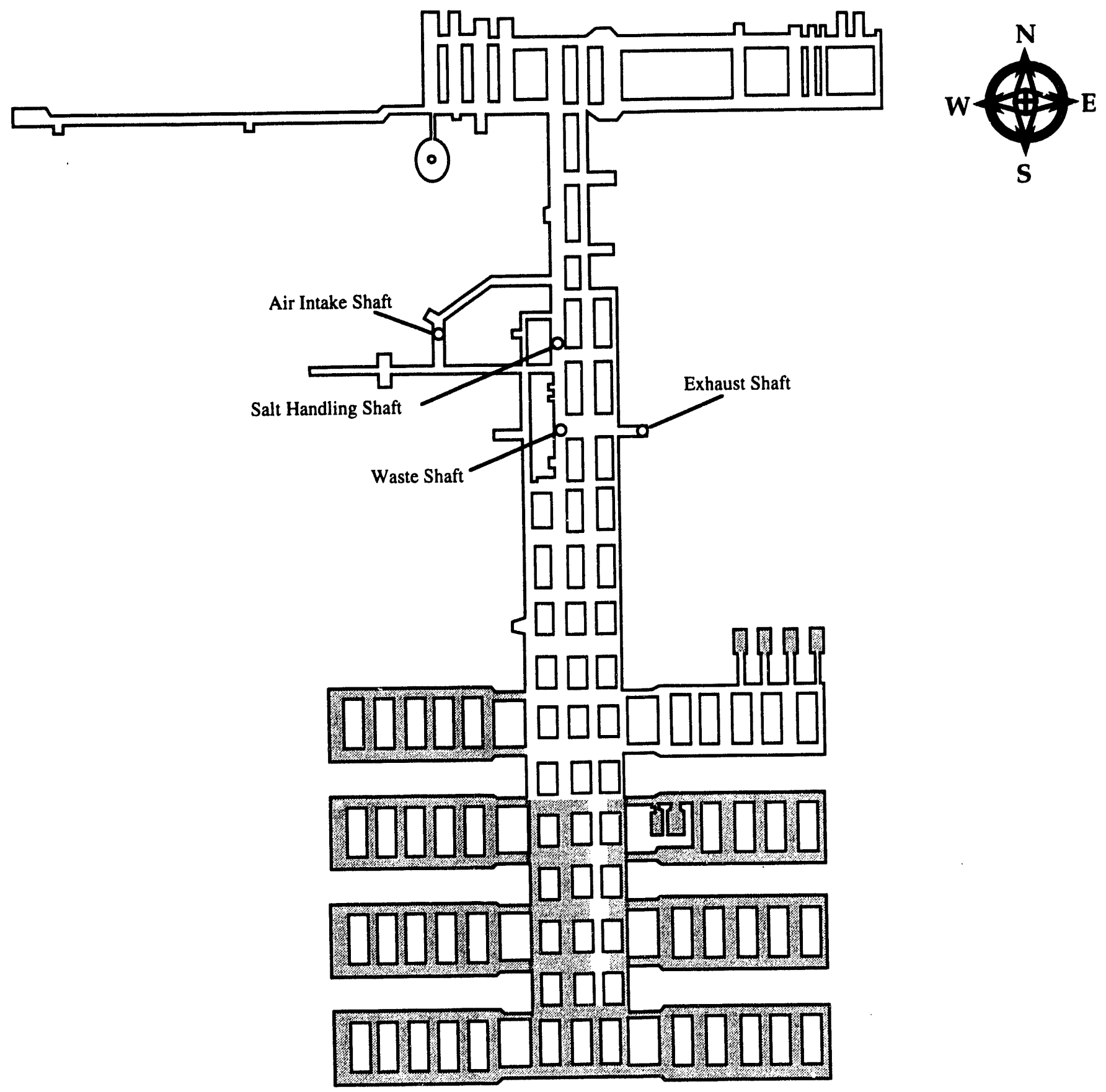

\section{Existing}

To be constructed 


\section{AMES LABORATORY \\ ENVIRONMENTAL RESTORATION AND WASTE MANAGEMENT FACILITIES}

\section{DESCRIPTION}

Ames Laboratory is located on the campus of Iowa State University (ISU) at Ames, Iowa. DOE owns twelve buildings on the campus and rents an additional 26,070 square feet from ISU. The primary missions of Ames Laboratory include basic and intermediate-range applied research in physical, mathematical and engineering sciences; material and chemical research applications pertaining to energy production and utilization; and technology transfer. Waste management activities at Ames include storage and preparation for off-site disposal of hazardous and radioactive wastes.

\section{AGREEMENTS}

None

\section{FACILITIES AND PROJECTS}

Underground Storage Tank - Assessment and remediation of contamination that resulted from an underground storage tank that leaked diesel fuel. The faulty tank was replaced 20 years ago. Assessment will include characterizing soil properties pertaining to site hydrogeology, and determining the extent of diesel fuel contamination in soil and groundwater.

Radioactive Waste Disposal Building - The Radioactive Waste Disposal Building is owned by ISU with Ames Laboratory maintaining beneficial use for packaging and preparation for shipment of all waste.

Ames Chemical Disposal Site - This site was active from 1958 through 1966. Chemical and biological wastes from routine laboratory operations were buried in nine unlined pits. Contaminants are thought to include uranium, thorium, yttrium, mercury, thallium, beryllium, pyrophoric materials, building debris, kerosene, and reactive metals such as sodium, potassium and lithium. The site will be characterized under a Remedial Investigation/Feasibility Study (RI/FS) model to fulfill requirements under the Iowa Administrative Code.

Inactive Waste Site Characterization Activities - Preliminary Assessment and Site Investigation of nine inactive sites involving areas of suspected contamination from Ames Laboratory activities conducted under the Manhattan Project and during the early years of the Atomic Energy Commission are complete. None of the sites is expected to need further remediation. 


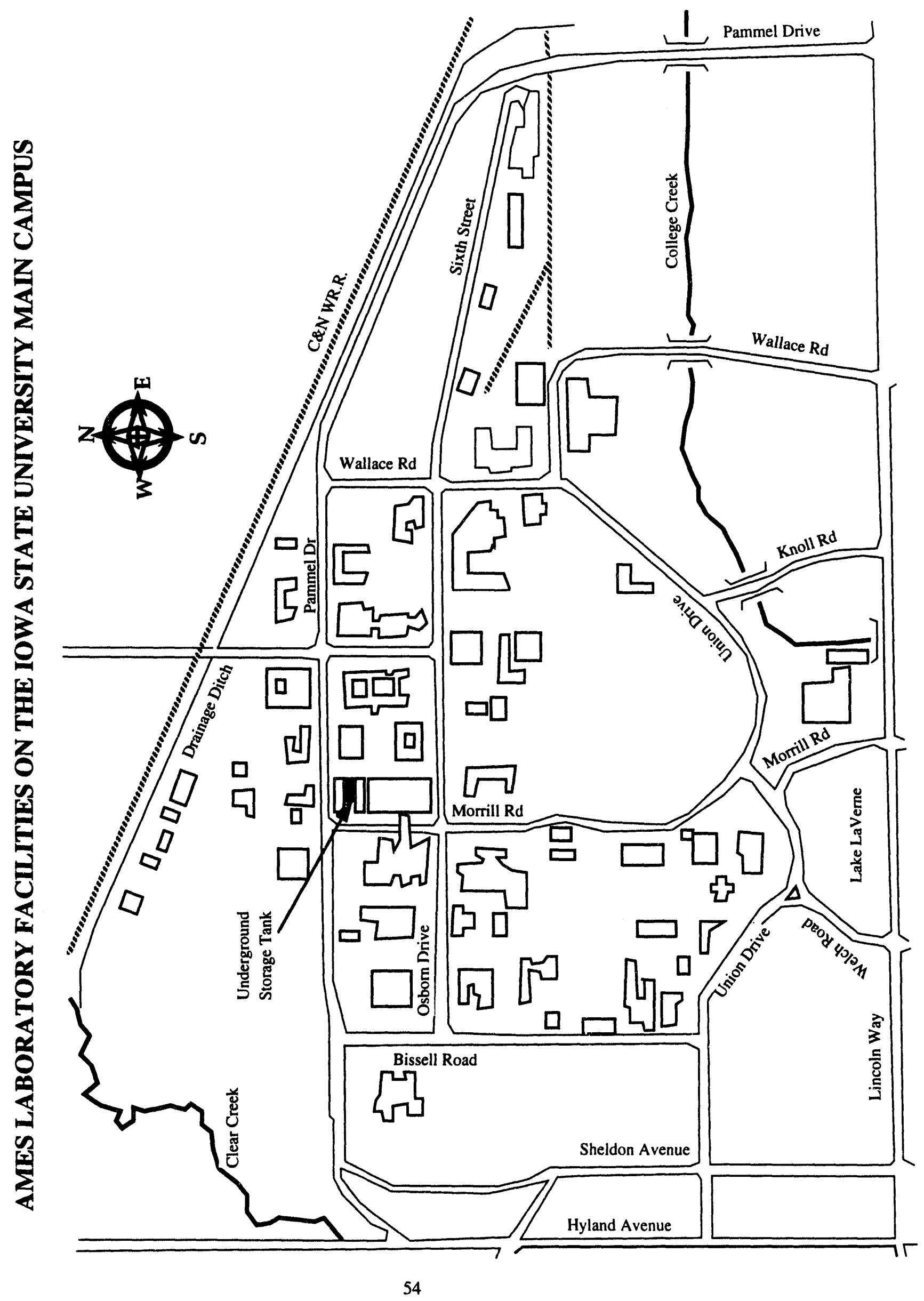




\section{AMES LABORATORY APPLIED SCIENCE CENTER}

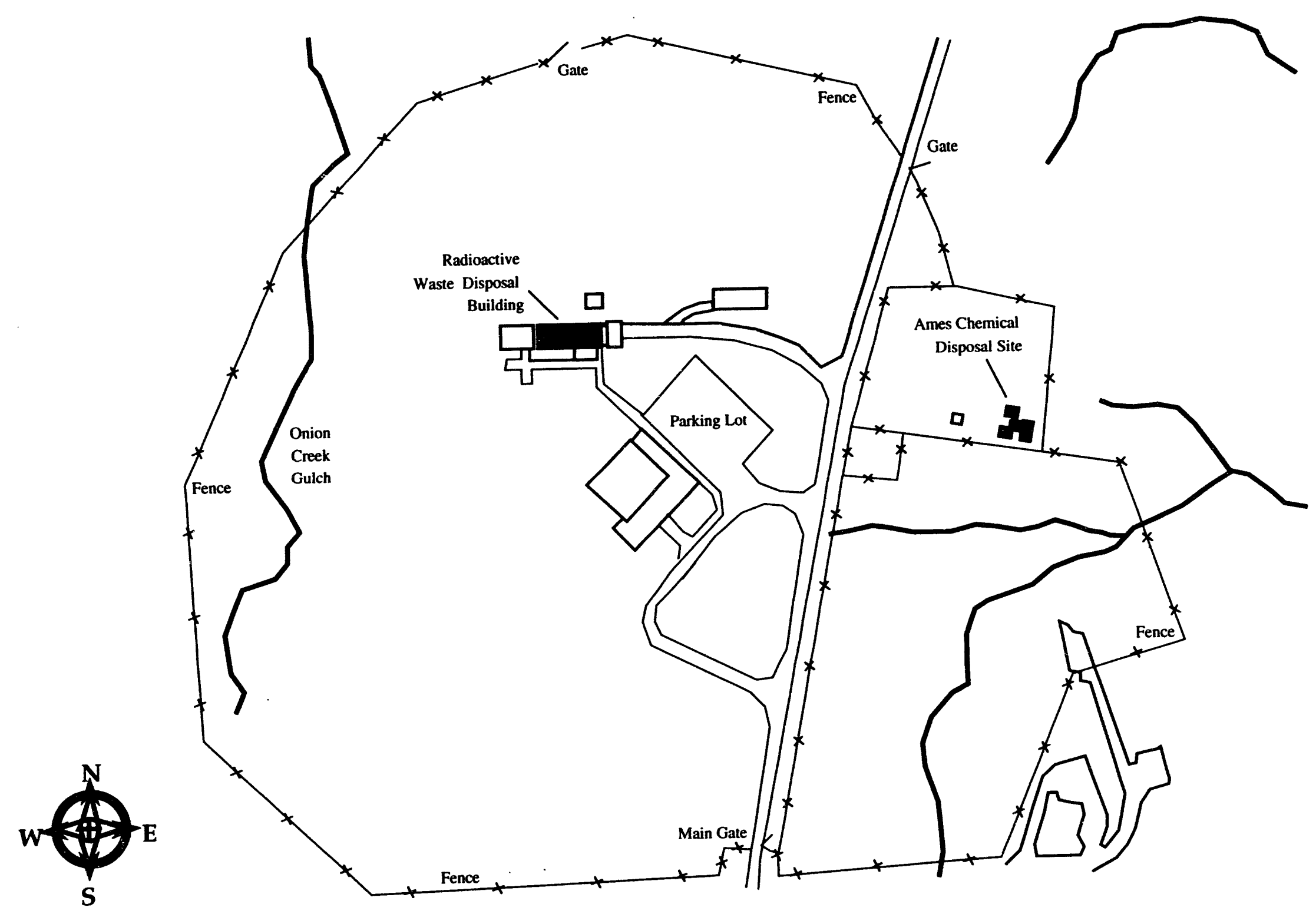




\section{ARGONNE NATIONAL LABORATORY-EAST \\ ENVIRONMENTAL RESTORATION AND WASTE MANAGEMENT FACILITIES}

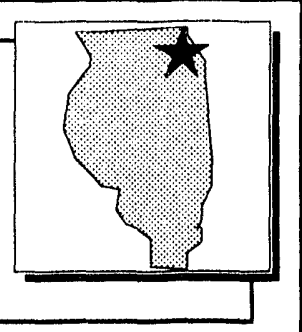

\section{DESCRIPTION}

Argonne National Laboratory-East (ANL-E) occupies a 1700-acre tract located approximately 22 miles southwest of downtown Chicago, in DuPage County, Illinois. ANL-E is a multidisciplinary research and development laboratory that conducts basic and applied research to support the development of energy-related technologies. Activities at ANL-E include nuclear reactor design, synchrotron radiation accelerator design, and environmental research programs. Specific environmental restoration activities conducted at ANL-E over the next several years will include multiple remedial action projects and several decontamination and decommissioning (D\&D) projects. Waste management work at ANL-E will include transportation, storage, and disposal of hazardous and radioactive wastes.

\section{AGREEMENTS}

None

\section{FACILITIES AND PROJECTS}

Hazardous, Radioactive and Mixed Waste Management Facilities - The Hazardous, Radioactive and Mixed Waste Management Facilities (Bldg. 306 and 306D annex) are the major waste operations facilities at ANL-E. Nearly all waste generated at ANL-E passes through these facilities. Operations include packaging, sorting, treatment with evaporator, storing, and preparation for shipment. Two line-item construction projects will rehabilitate the existing facilities and provide new storage for hazardous, radioactive, and mixed waste.

Radioactive Waste Storage Area - The Area 317 Radioactive Waste Storage Area includes open air storage of approximately 200 bins of low-level waste, and transuranic waste storage vaults. The transuranic waste vaults will be remediated upon completion of the Bldg. 306 area waste storage construction projects.

Hazardous Waste and PCB Storage - The Hazardous Waste and PCB storage facility (Bldg. 325C) consists of a small structure primarily used to temporarily house drummed PCB transformer oil prior to disposal. The facility has also been used to store minor quantities of hazardous waste. Hazardous waste storage is now primarily in Bldg. 306.

Laboratory and Sanitary Wastewater Treatment Plants - The 570 Area Laboratory and Sanitary Wastewater Treatment Plants collect and treat sanitary and laboratory wastewater in separate systems as required to meet National Pollutant Discharge Elimination System requirements. The facilities are outdated and deteriorated and will be upgraded to meet expected permit conditions.

Mixed Waste Storage - The Bldg. 329 Mixed Waste Storage facility is a small building that provides temporary storage for drummed scintillation cocktail vials. 
Canal Water Treatment Plant - This facility treats canal water and supplies cooling water to various facilities throughout the laboratory. The plant is deteriorated and will be upgraded.

Laboratory and Sanitary Sewer Rehabilitation - Laboratory and sanitary sewers on site have deteriorated and will be either replaced or rebuilt to alleviate excessive inflow and outflow from surrounding soil.

Rerouting and Plugging of Floor Drains - Approximately one-third of the floor drains tested so far discharge to storm sewers, sanitary sewers, or to the soil and need to be rerouted.

800 Area Landfill - The approximately 16-acre, unlined 800 Area Landfill was operational from 1966 to 1992 . It began closure in September 1992. The volume of waste contained in the landfill is approximately 320 acre-feet. Approximately 28,700 gallons of liquid hazardous waste were disposed of in a french drain. Known amounts of that waste are 8531 gallons of waste oil; 1875 gallons of volatile organic compounds; 533 gallons of kerosene and diesel fuel; and 110 gallons of PCBs.

East Area Sewage Treatment Plant - The East Area was the site of a number of temporary structures built in the late 1940s, some of which were used for production of reactor components and fuel assembly fabrication, as well as many other research and development activities. A small wastewater treatment facility located nearby chemically treated wastewater streams containing both radioactive and hazardous materials. The surrounding soil had been radioactively contaminated and was previously removed. Currently planned activities will address potential nonradioactive soil contamination. A preliminary characterization is being performed to determine the relative environmental risk of this area.

570 Holding Pond - The 570 Holding Pond is a small lagoon near the Argonne Wastewater Treatment Plant. The pond was used prior to 1960 for temporary storage of radiologically contaminated wastewater awaiting treatment in an ion exchange unit located nearby. The site was heavily disturbed in the 1960's by construction of additional wastewater retention tanks. Significant amounts of contaminated soil may have been spread in a surplus soils area west of the pond. A preliminary characterization is expected to be completed in 1994.

Sawmill Creek - Sawmill Creek is a small natural stream that passes through the eastern portion of Argonne and discharges to the Des Plaines River 6000 feet south of the site. Discoloration of stones and sediment in the creek was noted during an environmental survey in 1987. A preliminary characterization was completed in 1992. A preliminary site investigation and risk assessment will be completed by 1996.

317/319/ENE Area - The 317/319/ENE Area includes three separate areas used to dispose of waste. The 317 area consists of a series of underground concrete vaults used for temporary storage of transuranic waste. The facility also contains map tubes which were used for storage of reactor research materials. The 319 area was used from the mid-1950s to 1968 as the primary landfill at Argonne. The 317 and 319 areas, which are adjacent to the Waterfall Glen Forest Preserve, also were used for liquid hazardous waste disposal. ENE was used primarily for construction debris disposal from the mid-1940s to the early 1950s. Preliminary characterization and environmental monitoring indicates elevated levels of acetone, 2-butanone, chloroform, trichloroethene, 4-methyl-2-pentanone, other volatile organic compounds, and low levels of radionuclides.

100 Area - Various utility operations are located in this area, including the central boiler house and the water treatment plant. A number of activities are believed to have contaminated this area, such as storage of high and low sulfur coal in a bermed storage yard; operation of an unlined earthen wastewater lagoon; operation of an unlined lime sludge pond; past operation of large above-ground fuel oil storage tanks; past operation of a burn pit for open burning; and past operation of a small fossil fuel research and development facility equipped with an outside scrubber and wastewater retention pond. A preliminary site characterization is being performed to determine the relative environmental risk of this area. 
Outfall Areas - Over the years, quantities of hazardous chemicals have been released to several off-site locations (which originally were part of the site) through process water discharges. Some of the materials in these discharges could have accumulated in the soil and sediment downstream of the discharge points. Some of the activities and associated off-site locations are the AGS facility cooling tower flowdown discharges (chromium) which flowed through a small creek and into a large marshy area near the Des Plaines River; 317/319/ENE Area footing drain discharges and potentially contaminated stormwater runoff which flowed through a small stream and into a marshy area in the Waterfall Glen Forest Preserve; and stormwater runoff from the 800 Area which flowed into a small stream north of the site. A preliminary site characterization is being performed to determine the relative environmental risk of these areas.

Underground Storage Tanks - The current Underground Storage Tank systems are aged and ultimately will not comply with the mandatory IEPA UST regulations. This activity will remove those tanks that will not comply with regulations. The tanks are at a number of locations on site. All activities are completed.

Lime Sludge Removal - The scope of this project is to remove 100,000 cubic yards of lime sludge generated over a 30 year period by previous lime-soda softening of potable water at the water treatment plant. The lime sludge is located in an unlined lagoon adjacent to Sawmill Creek and separated from the creek by a dike. To prevent contamination of the creek and the groundwater, the sludge will be removed over a nine year period and applied to agricultural land as a soil conditioner.

Decontamination and Decommissioning of the Experimental Boiling Water Reactor (EBWR) -The EBWR was operated from 1956 to 1967 to demonstrate the use of a boiling water reactor as a heat source to generate electricity for distribution to the private sector. The current scope of this project is to remove the items inside the EBWR containment shell. As part of the final release survey, soil surrounding the containment shell periphery will be sampled to verify that it is clean. Close out is expected in 1997.

Decontamination and Decommissioning of the CP-5 Reactor - CP-5 Reactor was operated from 1954 to 1979. Initial decontamination and decommissioning began in 1990. The purpose of the project is to disassemble and remove all radioactive components, equipment, and structures. The final goal of the project is to release the facility for unrestricted use. Close out is expected in 2000.

Decontamination and Decommissioning of the Hot Cells - The purpose of this project is to decontaminate five hot cells in Building $200 \mathrm{M}$-Wing to reach restricted usage empty cell conditions; to decommission plutonium glovebox facilities in Building 212 D.Wing laboratories to unrestricted usage status by removal of all radioactive contamination; and to decommission eight shutdown hot cells in Building 301 by decontaminating the facility and demolishing the hot cells. Ninety percent of Argonne's offsite radioactive dose to the public is due to emissions from the M-Wing Hot Cells (radon 220), and completion of the project will eliminate that ninety percent. Building 200 is estimated to be completed in 1995, Building 212 is expected to be completed in 1996, and Building 301 is expected to be completed in 1998. 


\section{ARGONNE NATIONAL LABORATORY}

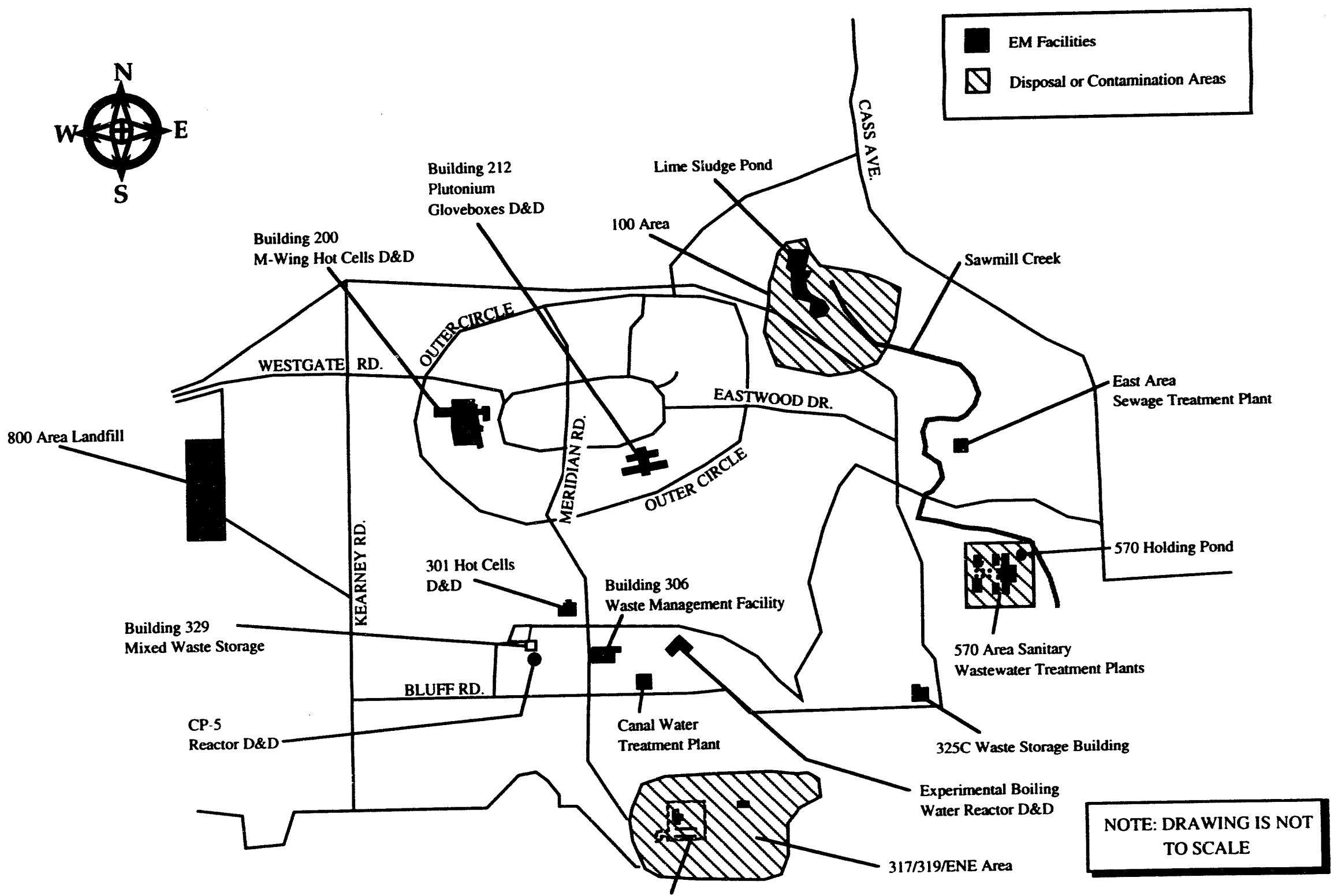

Radioactive Waste Storage Area 


\section{ARGONNE NATIONAL LABORATORY-WEST \\ ENVIRONMENTAL RESTORATION AND \\ WASTE MANAGEMENT ACTIVITIES}

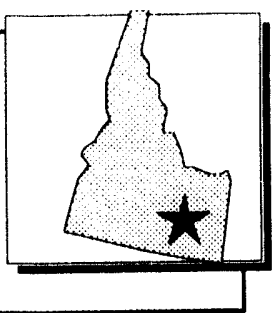

\section{DESCRIPTION}

Argonne National Laboratory-West (ANL-W) is located on the southeastern portion of the Idaho National Engineering Laboratory (INEL) near Idaho Falls, Idaho. The primary mission of ANL-W is research and development in support of the Nation's advanced reactor program. Reactor complexes at ANL-W include the Experimental Breeder Reactor II (EBR II), the Transient Reactor Test Facility (TREAT), and the Zero Power Physics Reactor (ZPPR).

\section{AGREEMENTS}

\section{Statute/Type}

Agreement-in-Principle
Facilities

INEL

INEL

CERCLA Federal Facility Agreement and Consent Order INEL

RCRA (LDR) Federal Facility Compliance Agreement INEL
Parties

DOE/ID

DOE/EPA

DOE/EPA/ID

DOE/EPA/ID

\section{Status}

Completed 5/21/90

Completed $7 / 10 / 87$

Completed 12/9/91

Under Negotiation

\section{FACILITIES AND PROJECTS}

Liner Installation - Approximately 1200 new cathodically protected liners will be installed at the Radioactive Scrap and Waste Facility (RSWF) to prevent contamination of soils.

Radioactive Liquid Waste Treatment Facility - Radioactive liquid wastes are processed in this facility through evaporation in Shielded Hot Air Drum Evaporators (SHADES).

Sodium Processing Facility - This facility will process sodium into sodium carbonate.

Future Waste Handling Facility - This proposed new facility would handle and prepare for disposal on-site generated hazardous waste, and would be used for temporary storage of low-level radioactive waste.

PCB Spill Cleanup - This activity involved cleanup of a historical PCB spill (up to $8000 \mathrm{ppm}$ ) in the EBR II transformer yard (area $20^{\prime}$ by $57^{\prime}$ ). Construction activities included removing and disposing of contaminated soil and transformer supports as necessary (approximately 505 cubic yards), and placing a two inch layer of bentonite as a moisture barrier above the rock where the decontamination goal of $25 \mathrm{ppm}$ could not be obtained. The physical cleanup was completed in June 1992. 
WAG 9 Assessment - Activities under this subproject are required under the Federal Facilities Agreement/ Consent Order (FFA/CO), and include background database development, investigation studies, and program support/database management. Two of the areas included in the investigation studies are the Industrial Waste Pond and the ANL Sewage Lagoons. The Industrial Waste Pond will be part of the ANL-W comprehensive Remedial Investigation and Feasability Study (RI/FS), and the ANL Sewage Lagoons are part of a Track 1 study of existing data.

Decontamination and Decommissioning of the Central Liquid Waste Processing Area - Use of the Central Liquid Waste Processing Area (CLPA) was discontinued in 1983 when the Radioactive Liquid Waste Treatment Facility began operations. This decontamination and decommissioning project is expected to involve approximately 5,000 cubic feet of low-level contaminated media, typically concrete, steel components, electrical wiring, instrumentation panels, and asbestos. The project is expected to take approximately two years to complete. Currently, there is no funding for the D\&D, and only on-going surveillance and maintenance is projected to occur. 


\section{ANL-W PROGRAMMATIC AND SUPPORT AREAS}

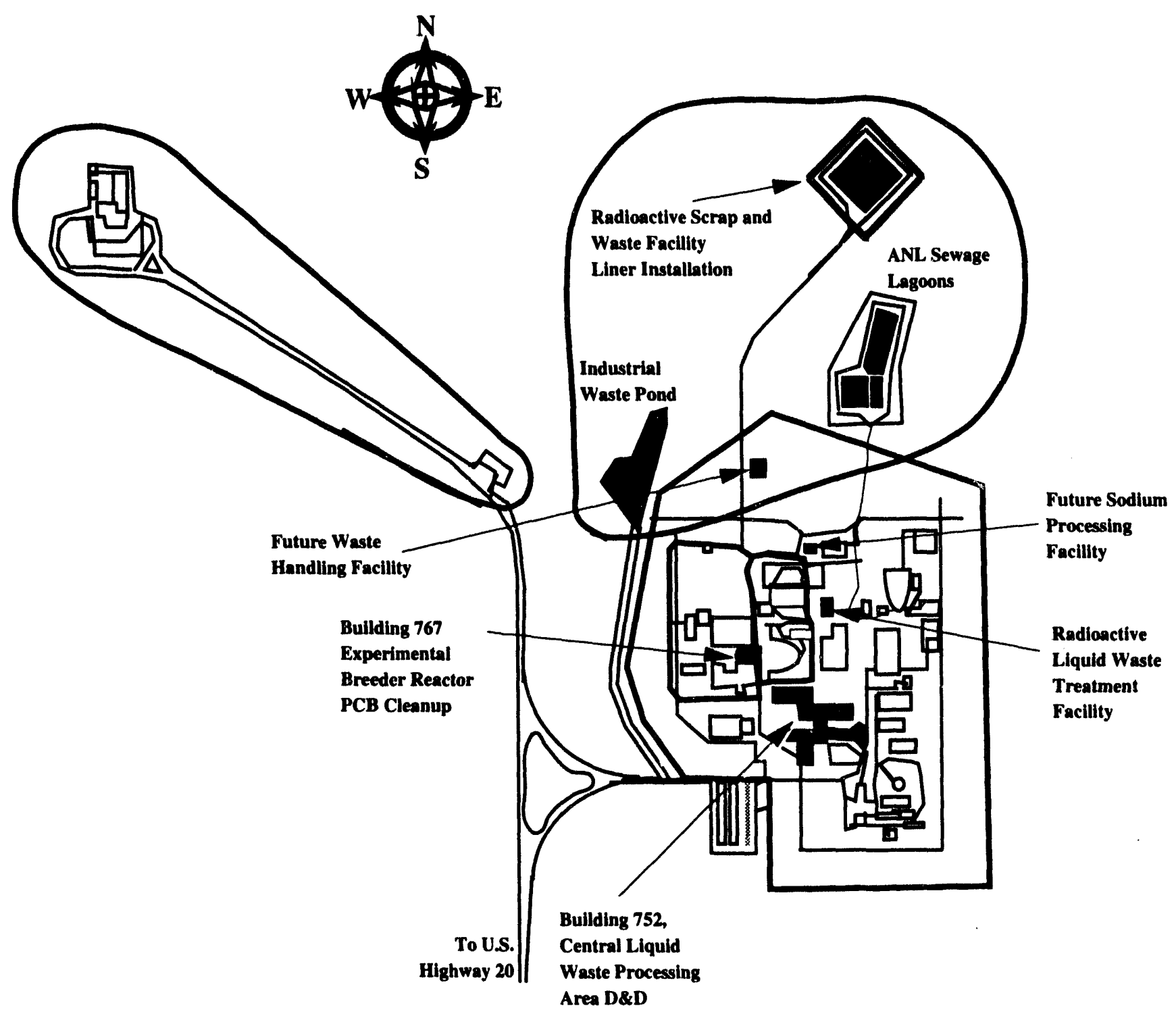




\section{BATTELLE COLUMBUS LABORATORIES}

\section{ENVIRONMENTAL RESTORATION AND WASTE MANAGEMENT FACILITIES}

\section{DESCRIPTION}

Beginning in 1943, the Battelle Memorial Institute (BMI), a privately-owned installation, performed atomic energy research and development work under contract to DOE and its precursor agencies. The Battelle facilities are located at BMI's Battelle Columbus Laboratories King Avenue site in Columbus, Ohio, and West Jefferson site at West Jefferson, Ohio. Fifteen buildings or portions thereof which became radioactively contaminated as a result of performance of work under the government contract are now being decontaminated and released to Battelle.

The type and extent of contamination varies from building to building, depending on the nature of nuclear research historically performed. Most of the contamination at the King Avenue site, for example, is due to uranium, thorium, and associated daughter products. These radioactively contaminated research facilities are located in older buildings that comprise part of the main Battelle campus across the street from Ohio State University. The immediate contiguous area can be characterized as a moderate density residential area. A river, which passes through the city, and several commercial and industrial areas are within one-half mile of the King Avenue site. The West Jefferson site consists of contaminated facilities similar to the King Avenue site, as well as a building containing a number of hot cells that are highly contaminated. The bulk of transuranic (TRU), mixed fission products, and activation product contamination is confined to the Nuclear Sciences Area of the West Jefferson site. The West Jefferson site lies in a rural agricultural setting in eastern Madison County, Ohio, which is 15 miles west of Columbus. The nearest residence is over a half mile from the site boundary.

DOE intends to return these facilities to a condition suitable for use without radiological restrictions. Actual future use of these facilities will be determined by Battelle. As a private, non-governmental entity, Battelle is responsible for maintaining its operations in full compliance with all applicable health, safety, and environmental laws and regulations. Battelle must also demonstrate compliance with NRC decommissioning requirements.

\section{AGREEMENTS}

1) D\&D is required as a close-out action for contract W-7405-ENG-92;

2) Specific requirements have been set also by the U.S. NRC pursuant to Battelle's nuclear materials license.

\section{FACILITIES AND PROJECTS}

Decontamination and Decommissioning (D\&D) is concerned primarily with safe caretaking of surplus nuclear facilities until either their decontamination for reuse or their complete removal. Buildings and adjacent grounds at Battelle are in various stages of decommissioning. 


\section{DECOMMISSIONING PROJECTS}

\section{King Street Campus}

\section{Building KA-A (Corporate Offices)}

Building $\mathbf{A}$ is the original laboratory building on the King Avenue campus, and currently houses corporate offices and a library. From 1952-1958, and at intervals in the 1960's and 1970's, work with natural uranium and thorium was conducted in different parts of the building. In the late 1970's, a decontamination effort was conducted prior to renovating the interior as office space. Current levels of contamination are low, covering $2,046 \mathrm{ft}^{2}$ in 11 rooms. Final decontamination of Building KA-A is scheduled for FY 1995.

\section{Building KA-1 (Foundry)}

This building housed a foundry with associated smelting, cutting, and grinding facilities. Historical work in the building included uranium ore benefication/extraction, melting, and casting, all resulting in widespread contamination. Approximately $14,000 \mathrm{ft}^{2}$, divided into 12 separate areas, will need to be treateed. Removal from the building of contaminated equipment will commence in FY 1994, followed by decontamination of surface areas in FY 1995.

\section{Building KA-2 (Metalworking Building)}

Building 2 contained large metal-working machinery, and was used extensively from the 1950 's to the early 1980 's to support fuel element fabrication studies, electroplating of reactor fuel, and uranium and thorium alloy testing. In addition to contamination on most of the metal working equipment, contamination also exists on highbay horizontal surfaces and in under-floor utility trenches. Removal of all equipment was completed in FY 1993. Decontamination of the remaining area is scheduled to start in FY 1996.

\section{Building KA-3 (Materials Building)}

Building KA-3 represents the most significant area of contamination on the King Avenue campus. This 2-story building housed multi-purpose laboratory areas used for research with enriched uranium, natural uranium, depleted uranium, and beryllium. Major facilities included powder metallurgy, metallography, and ceramics laboratories. Approximately $24,786 \mathrm{ft}^{2}$, or half of the building floor area, was contaminated with low levels of radioactivity. Removal of all laboratory equipment nd furnishings was completed in FY 1993. Decontamination of surfaces and excavation of contaminated drain lines is scheduled for completion in FY 1994.

\section{Building KA-4 (Radiochemistry Laboratory)}

This building once housed a radiochemistry laboratory and encapsulation facility for highly enriched uranium. Corrosion and metallurgical studies were also performed from the early 1950 's to the early 1960 's. The radiochemistry laboratory was decontaminated in 1980, but parts of the drain system are still radioactive as well as several rooms on the ground and second floors (approximately $14,000 \mathrm{ft}^{2}$ ). The schedule for decontamination of the building has been accelerated to FY 1994 to take advantage of a staff relocation by Battelle, thereby avoiding relocation costs. 


\section{Building KA-5 (Machine Shop)}

Building KA-5 contains laboratory areas and a high-bay machine shop occupying the entire ground floor. From 1951 until 1985 it was used for metallurgical studies of uranium, thorium, and beryllium. Contamination is present on and around some of the metal-working machines, as well as in ventilation hoods and ducts. A block of laboratories was decontaminated and released to Battelle for business use in FY 1991. Decontamination of the rest of the building is scheduled to start in FY 1994. Completion is targeted for late FY 1994 or early FY 1995.

\section{Building KA-6 (Chemistry Building)}

This four-story building houses laboratories devoted to analytical chemistry. Work on radioactive materials for the DOE involved alloy studies, corrosion testing, and fission gas analyses. In addition, the building housed a cobalt-60 irradiation facility. Low levels of residual contamination are known to exist in rooms, drains, and ventilation ducts in the northwest quadrant of the building (approximately 3,000 $\mathrm{ft}^{2}$ ). Decontamination of the building is scheduled to start $\mathrm{i}$ FY 1995 and be complete in mid-FY 1996.

\section{Building KA-6 (Chemistry Building)}

The building housed analytical chemistry activities in support of DOE studies from the 1950's to the early 1980 's. Radioactive contamination is present in the sinks and in the drain system on the first and third floors, as well as in certain floor areas and ventilation hoods/ducts (a total of approximately 7,000 $\mathrm{ft}^{2}$ ). Decontamination of an annex to Building 7 (KA-7A) was completed in FY 1993. Decontamination of the remainder of the building is scheduled to begin in FY 1995, with completion in FY 1996.

\section{Building KA-9 (Mechanical Engineering Building)}

This building contains a mezzanine office/laboratory area surrounding a central high bay. Between 1979 and 1984 investigations were conducted in the extrusion, bending, and shaping of tungsten-reinforced uranium and uranium composites. Three rooms were discovered to contain minor contamination and were successfully decontaminated in FY 1991.

\section{West Jefferson Site}

\section{Building.IN-1 (Hot Cells)}

The hot cells building at the West Jefferson site is the most significant challenge for the BCL Decommissioning Project. The building consists of a large high-energy cell and connecting pool for fuel assemblies, five smaller cells, and supporting facilities. The hot cell was one of the few facilities in the world capable of examination of complete reactor fuel assemblies. Extensive contamination from transuranics, fission products, activation products, uranium, thorium, decay products, and cobalt-60 exists throughout the hot cells, in the pool water, sludge, resins, filter media, and on interior cell surfaces.

Planning for decontamination and decommissioning of the hot cells is incomplete due to direction from DOE not to ship transuranic wastes to Hanford as originally planned. Lack of resolution of this issue (as well as funding constraints) has caused the completion date of the project to slip past the year 2000. The current assumed start date for decontamination efforts at Building JN-1 is FY 1997 (predicated on a transuranic waste storage site being designated by FY 1995). 


\section{Building JN-2 (Critical Assembly Building)}

Building JN-2 is a two-story office and laboratory building with attached high bay. It was designed and used for criticality studies, and also housed a plutonium laboratory and special nuclear materials vault. Contamination is minor and is found in three contiguous laboratories on the first floor, the vault, and in a drain system connecting to an underground holding tank. The building currently houses the project's radioanalytical laboratory. Because of this, JN-2 is the last building scheduled for completion, currently assumed to be FY 2000 .

\section{Building.JN-3 (Decommissioned Reactor)}

The reactor building has two above-grade floors, and one sub-grade level. The Battelle research reactor ran from 1956 to 1974 , at which time it was defuelled and decommissioned. The reinforced concrete reactor fuel storage pool was also used to test shipping cask integrity. Residual radioactivity in the structure is found in the core areas, the piping and drainage system, and the trench system at the base of the pool. The building has also been reconfigured to provide a staging area for segregation and packaging of waste generated by the clean-up of the other West Jefferson buildings. Final decontamination of JN-3 is scheduled for FY 1998.

\section{Buildings JS-1, IS-10, and JS-12}

These three buildings are located in the southern research area at the West Jefferson site. The buildings contained minor contamination resulting from material testing programs involving depleted uranium. Decontamination was completed in FY 1990. 


\section{BATTELLE COLUMBUS LABORATORIES KING AVENUE SITE}

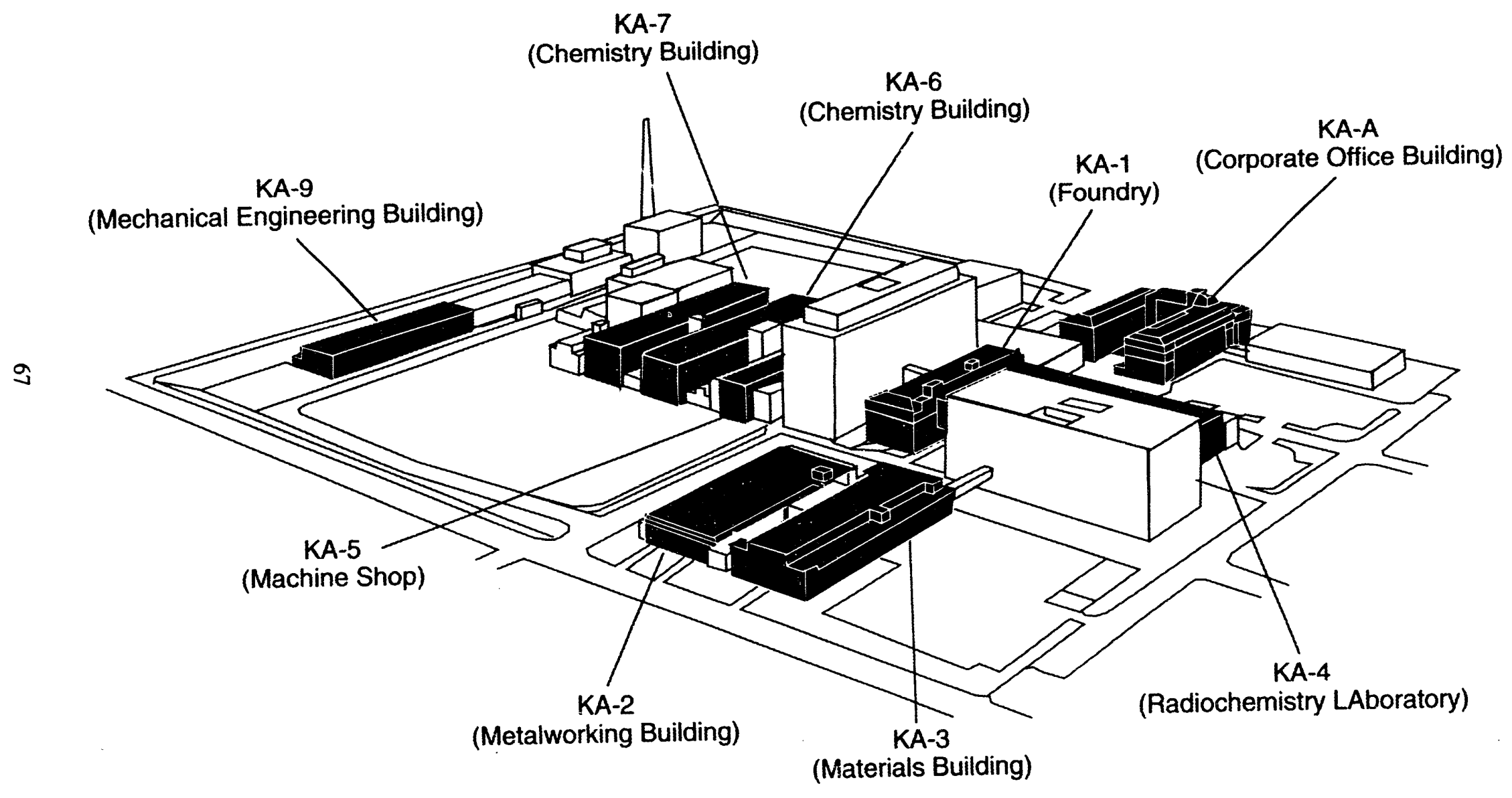




\section{BATTELLE COLUMBUS LABORATORIES WEST JEFFERSON NORTH AND SOUTH SITES}
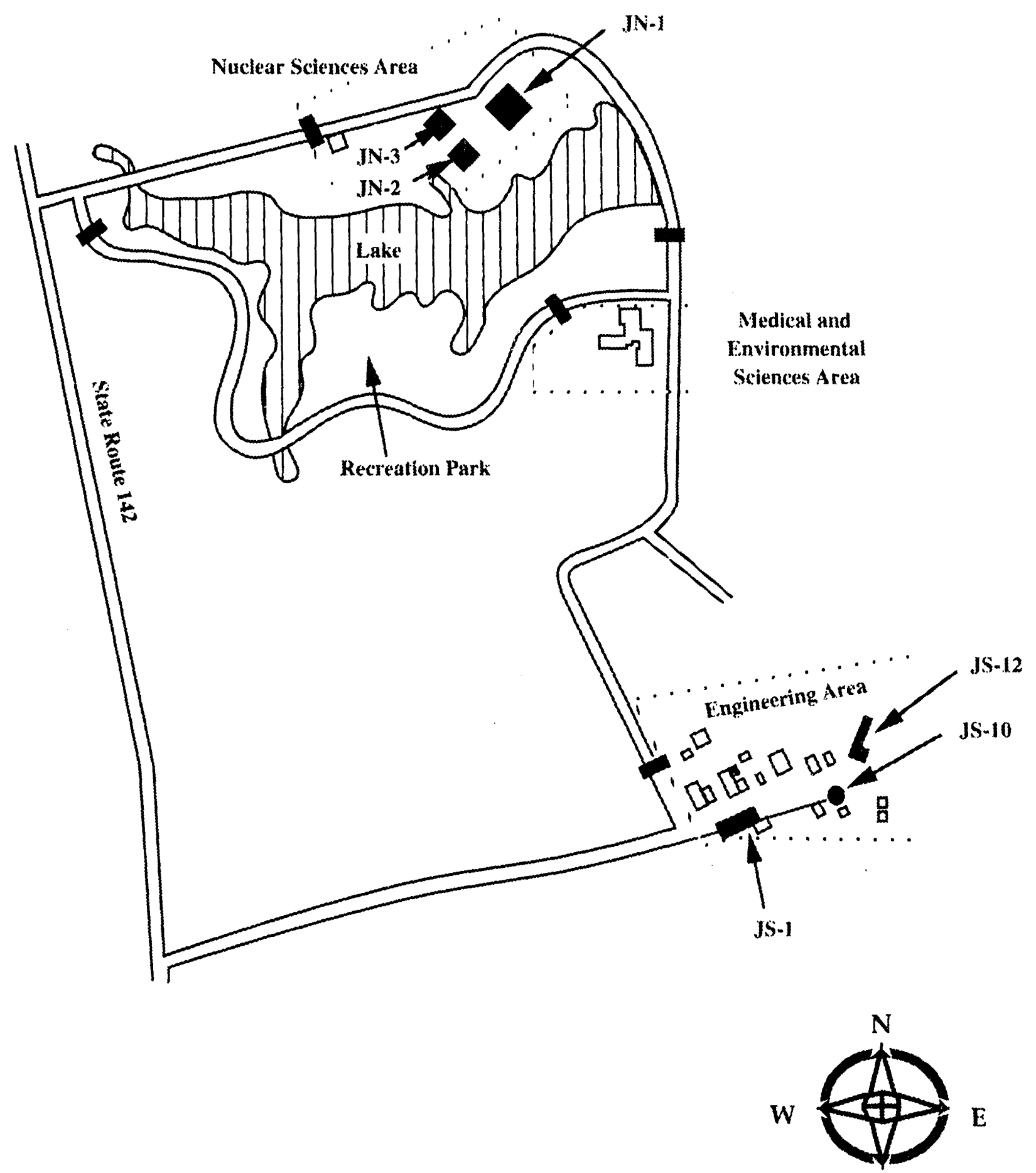


\section{BROOKHAVEN NATIONAL LABORATORY}

\section{ENVIRONMENTAL RESTORATION AND WASTE MANAGEMENT FACILITIES}

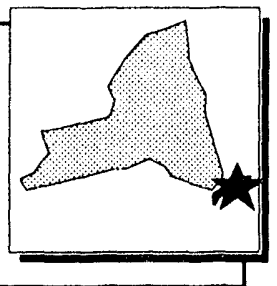

\section{DESCRIPTION}

Brookhaven National Laboratory (BNL) is a multipurpose research and development laboratory located in central Suffolk County on Long Island about 60 miles east of New York City. The site occupies about 8.3 square miles, which is mostly wooded, except for a developed area of about 2.6 square miles. To fulfill its role as a multiprogram laboratory, BNL directs scientific and technical efforts toward missions that include low-and high-energy physics, life sciences, and nuclear medicine research. To support the research programs, BNL operates the Alternating Gradient Synchrotron, the National Synchrotron Light Source, and the High-Flux Beam Reactor. The Laboratory is located over an EPA-designated, sole-source drinking water aquifer.

\section{AGREEMENTS}

\section{Statute/Type}

Toxic Substances

Control Act/Compliance

Agreement

CERCLA/RCRA Federal

Facilities/Interagency

Agreement

RCRA/TSCA Compliance

Agreement

\section{Facilities}

Brookhaven

National

Laboratory

Brookhaven

National

Laboratory

Brookhaven

National

Laboratory
Parties

DOE/EPA

DOE/EPA/NY

Completed 5/27/92

$\underline{\text { Status }}$

Completed 9/4/87

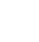

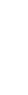

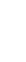

DOE/BNL/EPA Being Negotiated

\section{FACILITIES AND PROJECTS}

Waste Concentration Facility - The Building 811 Waste Concentration Facility (WCF) is used for processing of aqueous radioactive waste using blending tanks, $\mathrm{pH}$ adjustment, and an evaporator. The evaporator provides a liquid volume reduction of approximately $100: 1$. This operation annually handles 60,000 to 80,000 gallons of liquid low-level radioactive wastes from a number of BNL facilities.

Old Hazardous Waste Management Area - The Old Hazardous Waste Management Area (HWMA) complex is the principal area for on-site generated RCRA hazardous waste and radioactive waste storage, processing, and packaging. Facilities include: Building 448 , used for interim storage of slightly activated materials and scintillation waste; Building 444, used for storing and sorting nonradioactive hazardous waste; Building 446, used for sorting and compacting radioactive waste; the Work Area, Building 445, used as a worker facility; six boxcars used for bulk storage of supplies; and Building 483, used for non-radioactive, drummed hazardous materials.

Floor Drain Upgrades - This project will redirect laboratory wastewater discharges for 20 facilities from cesspools, dry wells, or stormwater systems into the existing central sewage system. The project will start in FY 1993, with completion expected in 1995. 
New Waste Management Facility - This new facility will replace the existing hazardous waste storage area. It will consist of a shielded radioactive waste storage building; a radioactive waste handling, storage and reclamation building; chemical and liquid waste handling and storage buildings; and operational buildings. The project will start in FY 1994 with completion scheduled for 1996.

Brookhaven Graphite Research Reactor Decontamination and Decommissioning - The Brookhaven Graphite Research Reactor (BGRR), which has been shut down since 1969, is scheduled to undergo decontamination and decommissioning (D\&D) in four phases. Phases I and II (above and below ground air ducts and underground lines) are already included within the EM-40 program as Areas of Concern (AOC) under the FFA/IAG and will be performed in conjunction with activities under Operable Unit (OU) II.

Operable Unit I - This operable unit consists of several locations, ranging from waste disposal sites to accidental spill areas, under the following AOCs: the Hazardous Waste Management Area (AOC 1); the Former Landfill Area (AOC 2); the Current Landfill (AOC 3); the southern component of the Offsite Tritium Plume (AOC 23); the Recharge Basin HS, (subAOC 24E); and the New Stormwater Runoff Recharge Basin, (subAOC 24F).

Operable Unit II - Operable Unit II, which encompasses the central area of Brookhaven, consists of various AOCs where radioactive materials are or were handled and stored as a result of Brookhaven operating practices. These AOCs include the BGRR (AOC 9); the Waste Concentration Facility (AOC 10); the Alternate Gradient Synchrotron (AGS) scrapyards (AOC 18); the sewerage system (AOC 21).

Operable Unit III - This operable unit encompasses the western portion of Brookhaven, and consists of locations ranging from waste disposal sites to accidental spill areas. The AOCs under this operable unit are as follows: Building 830 (AOC 11); the Bubble Chamber Area (AOC 14); potable/supply wells (subAOC 15A), consisting of nine wells (Nos. 1, 2, 3, 4, 6, 7, 10,11, and 12); and monitoring well 130-02 (subAOC 15B), the sitewide leaking sewage system (AOC 21); the TCE Spill Area (AOC 19); the Old Firehouse Area (AOC 22); process supply wells 104 \& 105 (AOC 24A); Recharge Basin HP (subAOC 24B), and Recharge Basin HN (subAOC 24C).

Operable Unit IV - Operable Unit IV is located in the eastern central portion of Brookhaven, and consists of the Central Steam Facility (AOC 5), which includes an unlined leaching pit and suspect fuel lines, and has had fuel spills; the Reclamation Area Building 650 Sump (AOC 6I), which had some inadvertent releases of slightly radioactive drainage water; supply/potable wells 1 and 3 (subAOC 15A); leaking sewer pipes in the study area (AOC 21); and Recharge Basin HO (subAOC 24D).

Operable Unit V - This operable unit encompasses the northeastern portion of Brookhaven and includes: the Sewage Treatment Plant and Satellite Disposal Area (AOC 4); the sewage system in the study area (AOC 21); and the eastern portion of the off-site tritium plume (AOC 23).

Operable Unit VI - Operable Unit VI is located in a remote eastern portion of Brookhaven. It consists of the Upland Recharge Area/Meadow Marsh (AOC 8).

Operable Unit VII - This operable unit pertains to low-level radioactive soil contaminants. It includes AOC 16, AOC 17, and the Particle Beam Dump.

Removal Activities - The five Removal Action Areas of Concern addressed under this activity are the Waste Concentration Facility (AOC 10A); Underground Storage Tanks (AOC 12); Cesspools (AOC 13); Hazardous Waste Management Facility - Spray Aeration Site (AOC 1B), and Mercury Cleanup in Building 464 (A.OC 27). 
Sitewide Activities - These activities include the Brookhaven Site-wide Hydrogeological Characterization, the Historical Site Review to identify potential other Areas of Concern, and any Preliminary Assessment/Site Inspections that may be required as a result of the Historical Site Review. 


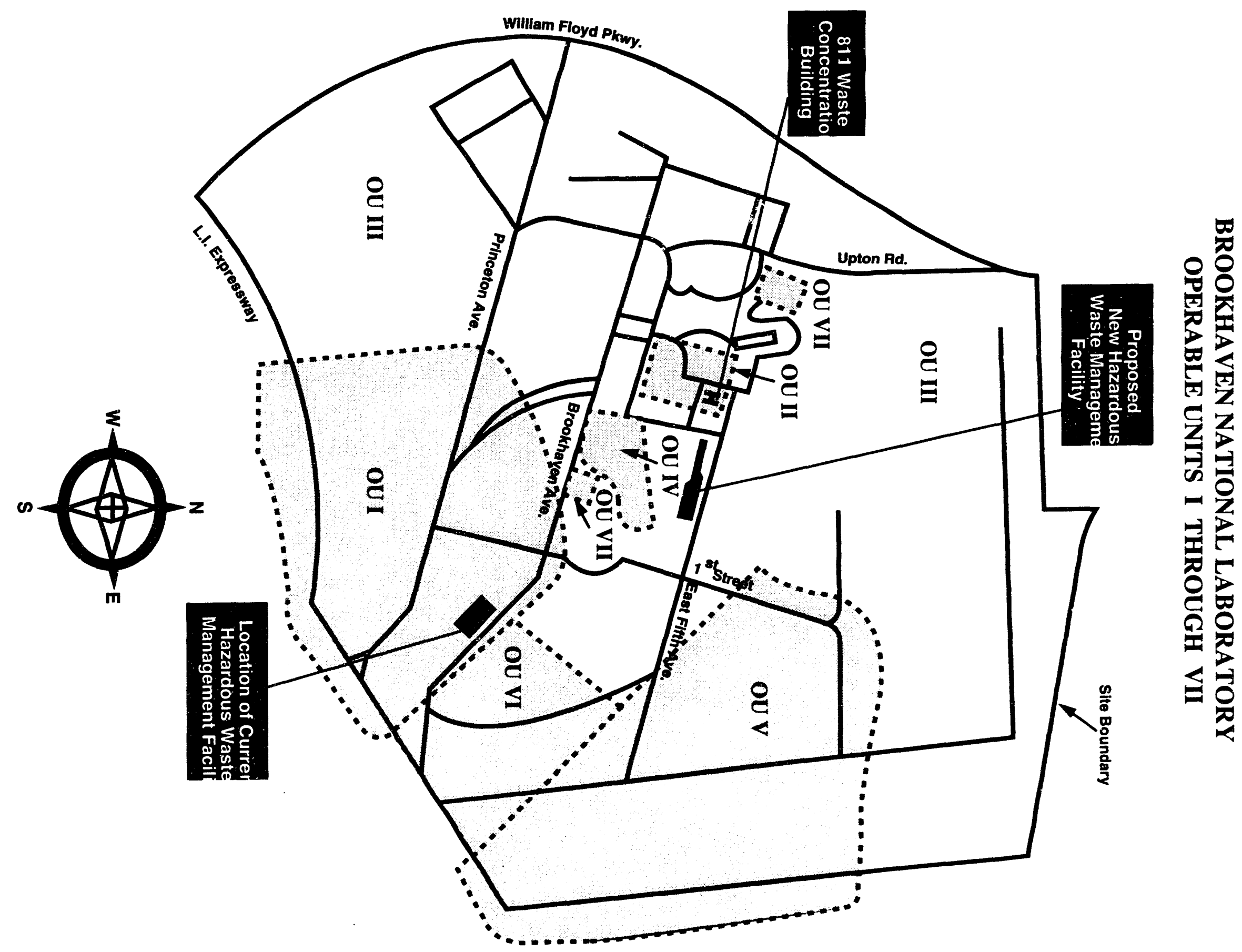




\section{FERMI NATIONAL ACCELERATOR LABORATORY}

ENVIRONMENTAL RESTORATION AND WASTE MANAGEMENT FACILITIES

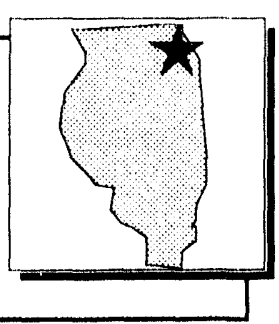

\section{DESCRIPTION}

Fermi National Accelerator Laboratory (Fermi), a 6800-acre site located in the far western suburbs of Chicago, Illinois, is a single-program installation for exploring the fundamental structure of matter using high-energy particle accelerators. Fermi operates the Tevatron, the world's highest energy accelerator in both fixed-target and colliding beam modes. The most important environmental concerns include the polychlorinated biphenyl (PCB) main ring spill cleanup and any possible cleanup required if the RCRA Facility Investigation (to be initiated in FY 94) detects any releases at solid waste management units.

\section{AGREEMENTS}

None

\section{FACILITIES AND PROJECTS}

Hazardous Waste Storage Area - The Hazardous Waste Storage Area at Site 55 consists of three buildings and one shed enclosed by security fencing. Operations include packing, sorting, storage, and material preparation for shipment. Building WS-1 is a RCRA Part B permitted facility for storage of RCRA waste.

Railhead Storage Area - The Railhead Storage Area is located on the northern perimeter of the site.

Warehousing and consolidation of radioactive and mixed waste and sorting and packing are conducted in this area. Bulk radioactive waste is stored and shipped off-site from this location. Usually one or two truckloads of low-level waste are shipped per year.

Radioactive Materials Processing and Storage Area - The radioactive materials processing area at Site 67 consists of a 70 year old barn and shed and a tent where radioactive waste is sorted, screened, packaged, compacted, solidified, and prepared for shipment.

Proposed Low-Level Radioactive Waste Sorting and Repackaging Building - This proposed facility is scheduled for construction completion in FY 1995 and will replace the present barn and tent. An Environmental Assessment is being prepared now and must be approved prior to detailed design proceeding.

Soil Contamination Cleanup - PCB contaminated soils near 24 main ring service buildings will be removed in stages through CY 2004. Cleanup of the first two service buildings is expected to be completed during the fourth quarter of FY 1993. 
Chromate Contamination Cleanup - Cooling tower blowdown containing zinc chromate was discharged to the Main Ring Perforated Pipe Field from 1974 to 1976. A preliminary assessment report has been completed and submitted to EPA. EPA placed this site on the "No Further Response Action Planned" list (see 57 FR 31758 , dated July 17, 1992). However, this same location has been identified by the Illinois EPA as a KCRA solid waste management unit. As such, additional soil and groundwater samples will be analyzed under the RCRA Facility Investigation. If necessary, the Pipe Field will be remediated. This would involve removal of approximately 150 cubic yards of material, based on past estimates.

Elgin Salvage and Supply Site - On April 19, 1993, U.S. EPA issued a Unilateral Administrative Order to Universities Research Association, contracted by DOE to operate Fermilab, requiring DOE and other "potentially responsible parties" to fund a site characterization study and cleanup, if necessary. The site study was started in July 1993 at the metals recycling facility, formerly used by Fermilab to recycle incidental quantities of metal scrap. Elgin Salvage and Supply is off-site, located 15 miles north of Fermilab. 


\section{FERMI NATIONAL ACCELERATOR LABORATORY}

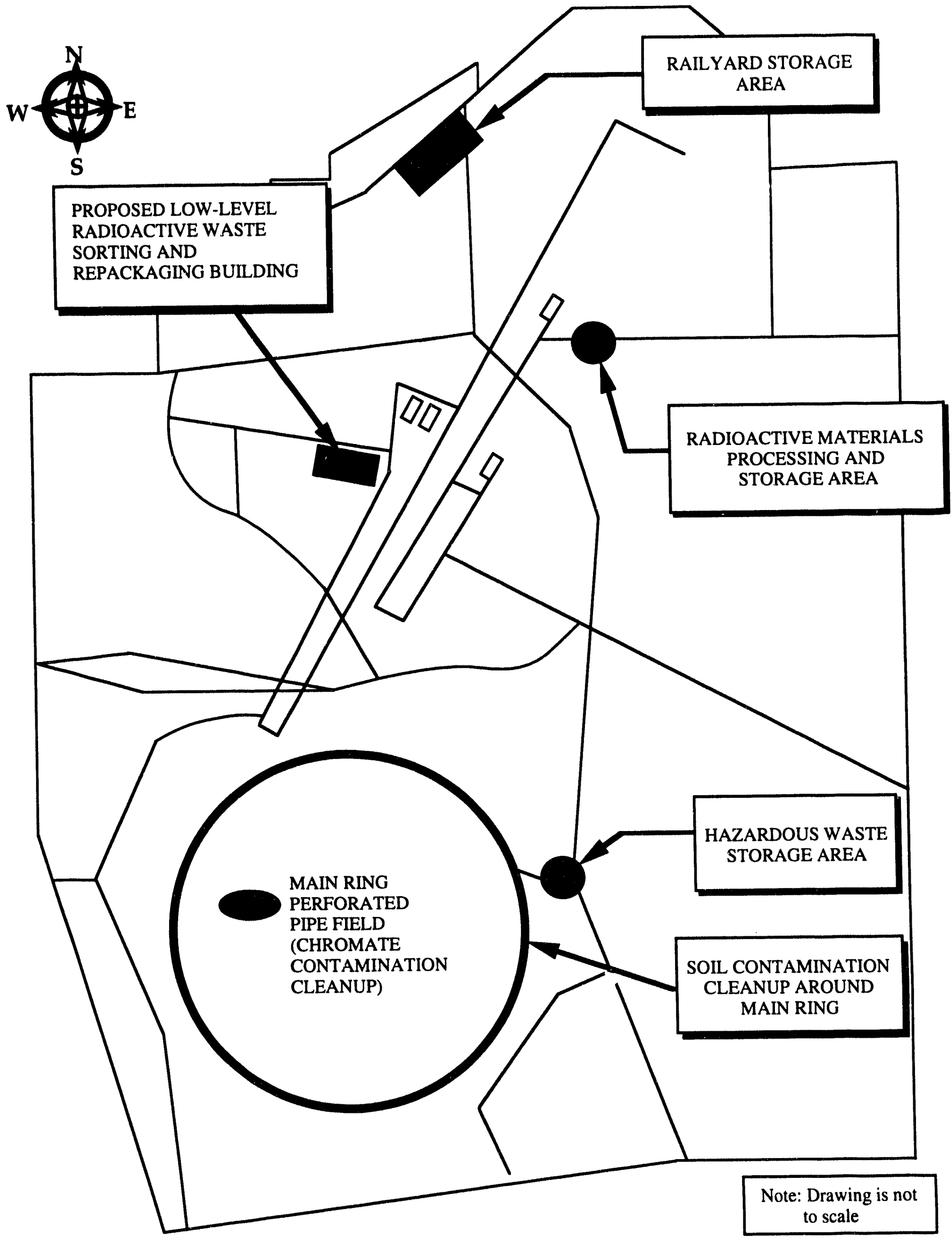




\section{PRINCETON PLASMA PHYSICS LABORATORY \\ ENVIRONMENTAL RESTORATION AND \\ WASTE MANAGEMENT FACILITIES}

\section{DESCRIPTION}

Princeton Plasma Physics Laboratory (PPPL) is located on 72 acres of land leased from Princeton University. The primary mission of the laboratory is magnetic confinement plasma physics fusion energy research. PPPL has two large tokomak devices; the Princeton Beta-Experiment-Modification (PBX-M) and the Tokomak Fusion Test Reactor (TFTR). Waste management activities include collection, storage and off-site disposal of hazardous and radioactive waste.

\section{AGREEMENTS}

None

\section{FACILITIES AND PROJECTS}

Underground Storage Tank Remediation - Underground storage tanks in several locations on the site are being removed and contaminated soils are being disposed of.

Hazmat Facility - The Hazmat Facility is a 90-day RCRA storage facility. It is scheduled for upgrade in FY 1993.

Basin Liners - The detention basin collects runoff from most of the laboratory. A liner is currently being installed.

Boneyard - The boneyard is used to store all radioactive waste prior to shipment.

Stormwater Outflow - Stormwater discharges throughout the site will be monitored and analyzed during storm events.

Groundwater Characterization/Remediation - Groundwater monitoring and soil gas investigations in 1990 and 1991 indicate that groundwater may have been contaminated by leaks from underground storage tanks and by past practices of uncontrolled chemical spills. This subproject will determine the extent and the source of volatile organic compounds contaminating the groundwater.

CERCLA Past Waste Site Investigation - This activity will consist of a survey of C and D sites of Princeton Plasma Physics Laboratory to determine if there have been any unreported releases of hazardous substances. 
PRINCETON PLASMA PHYSICS LABORATORY

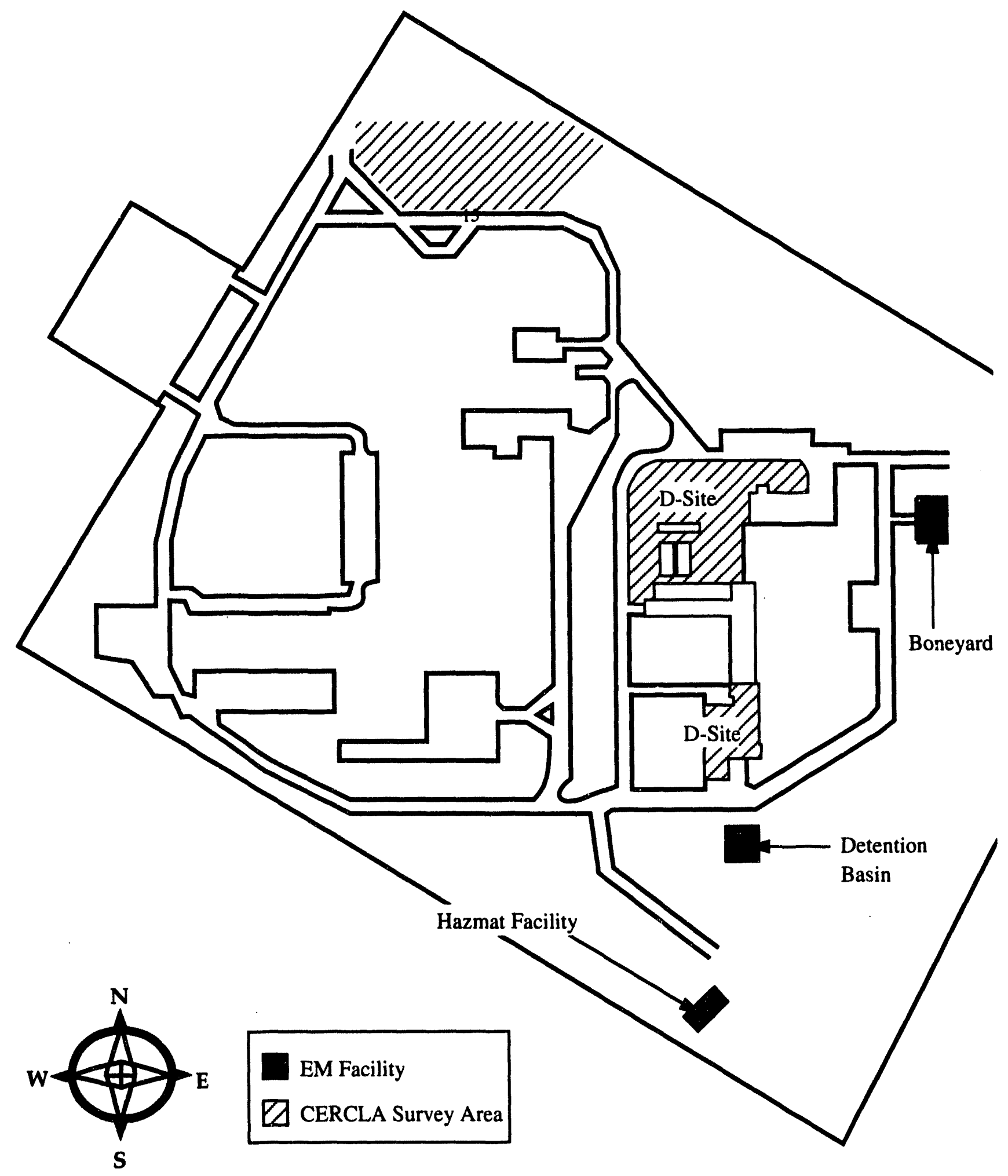




\section{FERNALD ENVIRONMENTAL MANAGEMENT PROJECT \\ ENVIRONMENTAL RESTORATION AND WASTE MANAGEMENT FACILITIES}

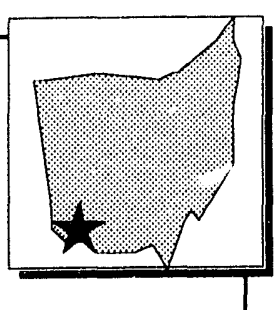

\section{DESCRIPTION}

The Fernald Environmental Management Project (FEMP) near Fernald, Ohio, located 17 miles northwest of Cincinnati, is a large-scale facility with a primary mission that has shifted from production of uranium metals and compounds to completion of environmental restoration. Cleanup of the 1050-acre site and support of the waste management and base services activities are now the major site activitics.

\section{AGREEMENTS}

\section{Statute/Type}

Agreement-in-Principle

CERCLA, RCRA, Clean Air

Act/ Federal Facility Compliance Agreement

RCRA/CWA Consent Decree

RCRA Amended Consent Decree

Clean Air Act, National

Emissions Standards for Hazardous Air Pollutants/ Federal Facilities Agreement for Control and Abatement of Radon - 222

CERCLA Consent Agreement

CERCLA Consent

Agreement-Amended

OU \#2 Settlement Agreement
Facilities

FEMP

MP

MP

FEMP

FEMP

FEMP

FEMP

FEMP
Parties

DOE/OH

DOE/EPA

DOE/OH

DOE/OH

DOE/EPA

Completed 11/14/91

DOE/EPA

Completed 6/29/90

DOE/EPA

Completed 9/91

Completed 4/93 


\section{FACILITIES AND PKOJECTS}

\section{Operable Unit 1. Waste Pit Area}

This unit includes waste pits 1-6, clearwell, burnpit, berms, liners and soil within the operable unit boundary. Pits 1 through 3 are covered with soil. Pit 4 is covered with bentonite clay and a synthetic cover. Pits 5 and 6 are lined with synthetic membranes. The burn pit was taken out of service in 1970 . The clearwell was a settling basin for stormwater runoff from a portion of the storage basin.

\section{Operable Unit 2. Other Waste Units}

This unit includes a formerly active flyash pile, other south field disposal areas, lime sludge ponds, solid waste landfill, inactive flyasin pile disposal area, berms, liners, and soil within the operable unit boundary. Operable Unit 2 contains large volumes of waste materials with relatively low concentrations of radioactive and chemical contaminants.

\section{Operable Unit 3, Former Production Area}

This unit, the former production area and other production-oriented facilities and equipment, is one of the largest and most complex of the FEMP Operable Units. There is a wide variety of former processing facilities within the 136-acre area. The primary contaminant is uranium and the main focal points of cleanups are perched groundwater, buildings, equipment, and support facilities.

\section{Operable Unit 4, Silos 1-4}

This unit includes silos 1, 2, 3, and 4, berms, decant tank system, and soil within the operable unit boundary. Silos 1 and 2 contain radium-bearing radioactive wastes resulting from the processing of pitchblende ore for its uranium content. The silos were constructed in the early 1950 s and were reinforced with an earthen berm in 1964. Other past improvements included the installation of a cap and the application of a polyurethane foam coating over the domes for weather protection. A radon treatment system was conscructed and radon gas monitors were installed around the FEMP boundary in the vicinity of silos 1 and 2. In 1991, a 1-ft. layer of bentonite clay was placed over the residues to retard radon emanation rates and to reduce the potential for releases in the event of dome failure. Silo 3 contains dried, uranium-bearing metal oxide waste. Silo 4 is empty.

\section{Operable Unit 5, Environmental Media}

This unit encompasses the environmental media at FEMP that could be impacted by the facility. The media include the groundwater, surface water, soil not included in the definitions of OU \#1-4, sediments, vegetation and wildlife. The groundwater includes the Great Miami Aquifer. 
FERNALD ENVIRONMENTAL MANAGEMENT PROJECT

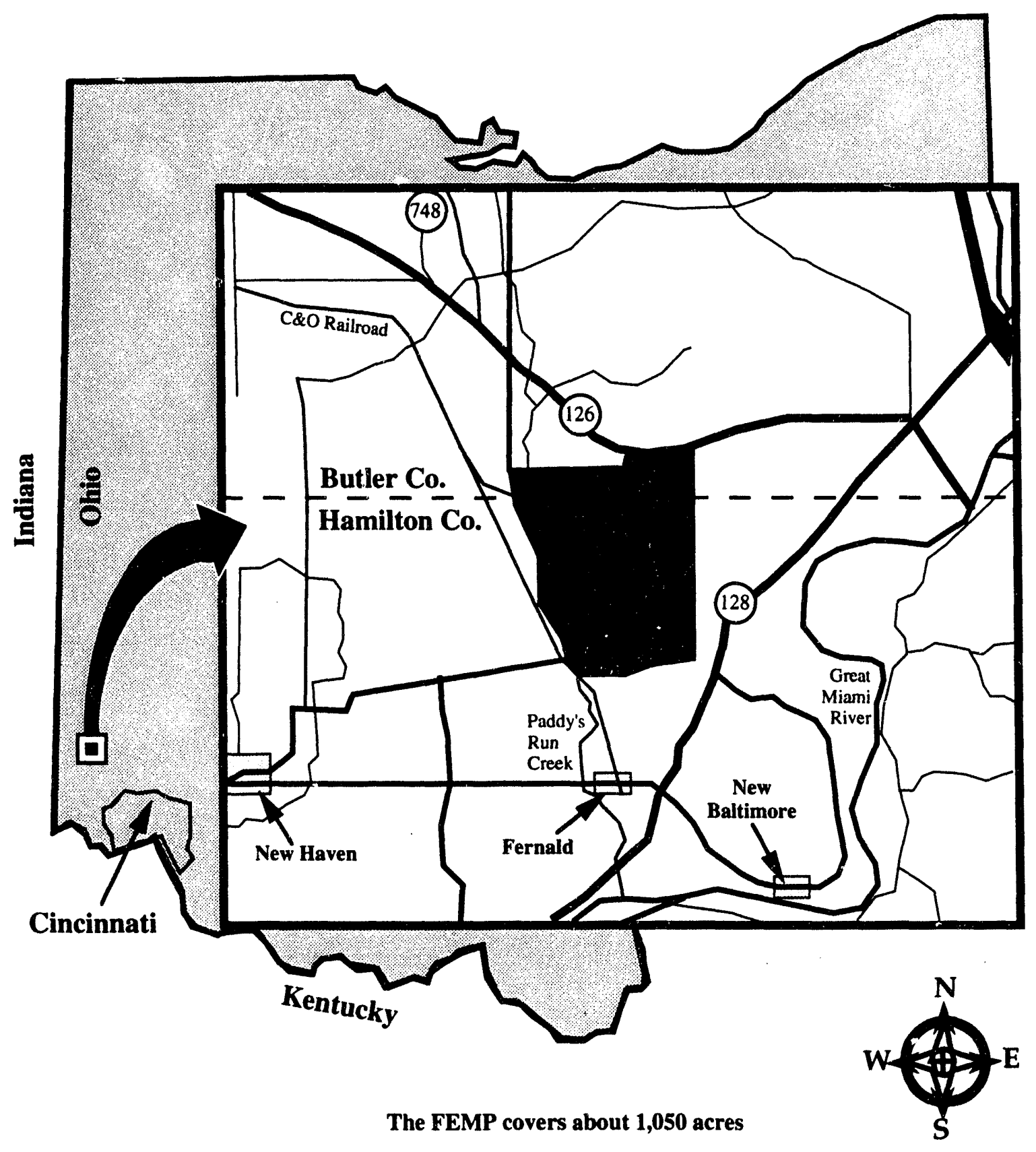




\section{FERNALD ENVIRONMENTAL MANAGEMENT PROJECT OPERABLE UNITS}

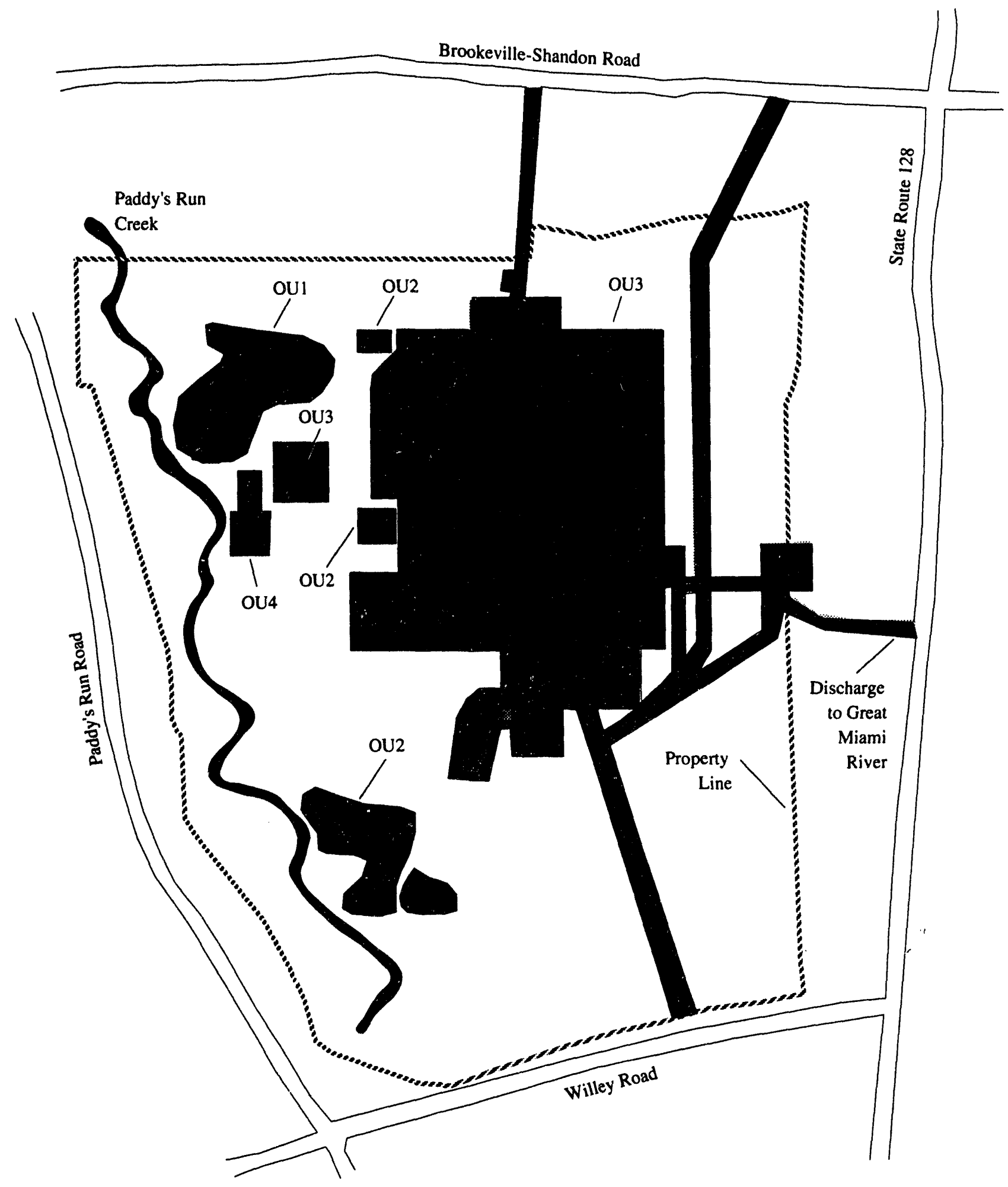




\section{IDAHO NATIONAL ENGINEERING LABORATORY}

ENVIRONMENTAL RESTORATION AND WASTE MANAGEMENT FACILITIES

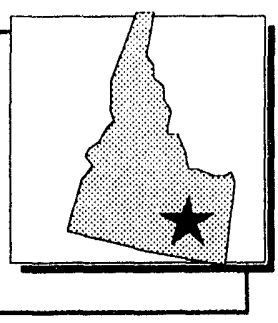

\section{DESCRIPTION}

Idaho National Engineering Laboratory (INEL) is situated in southern Idaho along the western edge of the Eastern Snake River Plains and encompasses a desert area of approximetoly 890 square miles. The nearest major community is Idaho Falls (population 46,000), located 42 miles southeast of INEL. Activities at INEL include the operation of nuclear reactors, fuel processing plants, waste management facilities, and other supporting facilities. The primary focus of work at INEL is its environmental restoration, waste management, and technology development activities.

\section{AGREEMENTS}

\section{Statute/Type}

Agreement-in-Principle

RCRA Compliance Agreement

CERCLA/RCRA Interagency

Agreement

RCRA (LDR) Federal Facility

Compliance Agreement

RCRA/Air/Water Consent Orders
Facilities

INEL

INEL

INEL

INEL

INEL
Parties

DOE/ID

DOE/EPA

DOE/EPA/ID

DOE/EPA/ID

$\mathrm{DOE} / \mathrm{ID}$ $\underline{\text { Status }}$

Completed 5/21/90

Completed 7/10/87

Completed 12/9/91

Under Negotiation

Completed 2/11/92, $4 / 3 / 92$ and $10 / 6 / 92$

\section{FACILITIES AND PROJECTS}

Waste Experimental Reduction Facility (WERF) - The mission of WERF is to act as the central INEL location for processing and handling low-level radioactive waste for disposal at the Radioactive Waste Management Complex (RWMC), and to develop and apply safe and efficient production scale methods for volume reducing and stabilizing low-level radioactive and mixed waste while transferring the technology and operating philosophy to other potential users. The following capabilities have been established at WERF:

- An incinerator capable of incinerating both low-level and mixed low-level wastes.

- A metal processing facility capable of volume reducing contaminated, non-irradiated metals through size reduction and packaging 
- A 200-ton box compactor capable of processing noncombustible materials;

- A waste stabilization system to solidify the incinerator ash residue and other waste streams;

- A capability to act as a centralized waste processing center for the INEL to sort and pack waste into containers suitable for disposal and to comply with waste class segregation requirements; and

Mixed Waste Storage Facility (MWSF) - The mission of the MWSF is to store low-level mixed waste and mixed PCBs in compliance with RCRA and TSCA (40 CFR 261 and CFR 761). Waste is stored at the facility until treatment and disposal, in compliance with RCRA and TSCA regulations, can be accomplished. The following features exist:

- A storage facility that has been retrofitted to store mixed waste in a below grade reactor pit. Waste handing capability to the pit is provided by a 12 -ton pendant controlled crane; and

- Segregated areas to accommodate storage of PCBs, corrosives, and flammables in compliance with RCRA and TSCA requirements. Special provisions for these waste forms include isolation diking and ventilation systems.

Revisions to the RCRA permit and safety analysis documents are currently being pursued to increase facility capacity to meet foreseeable storage needs. A replacement facility is in design stages. Once the new facility is operational, the MWSF will be used as a contingency storage facility.

Hazardous Waste Storage Facility (HWSF) - The mission of the HWSF is to serve as a interim storage area for nonradioactive hazardous waste. It serves as an INEL collection point for DOE-RCRA waste prior to shipment off-site for treatment and disposal. The following features exist:

- A storage facility that was a 1950 explosives burner of approximately 2000 square feet has been retrofitted to store RCRA waste. The handling operations may also include overpacking, sampling, further identification or additional documentation; and

- Divided areas to accommodate flammable storage with added safety precautions and curbed areas to segregate categories of waste and PCBs.

ICPP Waste Management Operations/Facilities - The major waste management activities at the Idaho Chemical Processing Plant (ICPP) are the storage of mixed high-level liquid waste in the tank farm, calcining of this waste to granular solids in the New Waste Calcining Facility (NWCF), and subsequent storage of these solids in stainless steel bins inside concrete vaults. The ICPP also receives and stores spent reactor fuel from the Navy and other assigned spent nuclear fuel.

The ICPP has several buildings and structures that handle the three basic waste forms - liquid, solid, and gases. Radioactive, hazardous and mixed waste are handled and treated in the safest way possible. ICPP waste management consists of eight major systems: (1) a tank farm for interim storage of mixed high-level radioactive liquid wastes; (2) a process equipment waste (PEW) evaporator system for concentrating low-level radioactive liquid wastes; (3) a service waste system for disposal of process and other waste water; (4) the New Waste Calcining Facility (NWCF) for converting the mixed, high-level radioactive liquid wastes to a free-flowing solid (Calcine); (5) bins for storage of the calcine; (6) solid waste staging areas; (7) hazardous waste staging areas; and (8) off-gas cleanup and an Atmospheric Protection System (APS) for gaseous waste treatment.

Liquid wastes at ICPP consist primarily of: (1) mixed radioactive solutions generated during fuel reprocessing; (2) decontamination solutions; and (3) waste water from utility operations, heating and cooling systems, and laboratory or other floor drains. 
Spent fuel at the ICPP is stored in two ways: (1) in water-filled basins, and (2) in a dry, shielded storage environment.

Gaseous waste includes off-gas produced from various processes and potentially contaminated ventilation air. Solid waste typically includes items such as rags, contaminated tools and equipment, and other miscellaneous items that are generated as a result of operations, maintenance, construction, and decontamination work.

Tank Farm - Mixed high-level liquid waste is temporarily stored in underground stainless steel vessels at the tank farm. This waste is eventually processed through the New Waste Calcining Facility (NWCF, CPP-659) and converted to a granular solid called calcine.

The tank farm contains two 318,000-gallon tanks (WM-180 and 181), nine 300,000-gallon tanks (WM-183 to 190 ) and four 30,000 gallon tanks (WM-103 to 106). Eight of the large tanks and all four small tanks have cooling coils to permit storage of radioactive solutions that generate large quantities of heat. All of the large tanks are contained in concrete vaults with sumps. Each tank and vault structure is covered with ten feet of earth for shielding.

One of the large tanks, WM-190, is maintained empty; it is designated at the "safety spare" and would receive waste from another tank if a leak developed. The small tanks, WM-103 through 106, are not in use since they are not contained in vaults. Authorization from DOE is required prior to emergency use of these tanks.

Interconnecting lines and valves, an airlift pit, cooling equipment, diversion equipment, instrumentation, and controls are provided within the tank farm perimeter. An impermeable membrane is installed 6 inches below grade; this membrane minimizes groundwater leakage into the tank vaults. A cathodic protection system is installed to protect underground lines against corrosion.

Four 18,400-gallon hold tanks (WL-101 and WM-100 through WM-102), equipped with cooling coils and housed in underground concrete vaults adjoining the north side of the Waste Treatment Building (CPP-604), provide short term storage of nonradioactive liquid waste prior to transfer to the tank farm. The WL-101 vessel is the holding tank for PEW evaporator bottoms; the WM-100 through WM-102 vessels can receive radioactive liquid waste from various plant processes.

Process Equipment Waste (PEW) Evaporator - The PEW Evaporator system is located in the Waste Treatment Building, CPP-604. The supporting ventilation systems are in the Blower Building, CPP-605. The majority of the CPP-604 building is underground and is constructeu of reinforced concrete. This building contains the PEW system (east end), storage tank cells and sample corridor (north end), and the Rare Gas Plant (west end).

CPP-605 is constructed of steel frame and transite siding aboveground and reinforced concrete belowground. The building houses the CP-604/605 supply ventilation fans and the main exhaust fans for the Atmospheric Protection System.

Low-level liquid wastes are collected in hold tanks at the various ICPP facilities and are then processed through one of two PEW evaporators for concentration. The PEW evaporator bottoms are transferred to the tank farm via WL-101. The overhead is condensed and sent to the Liquid Effluent Treatment \& Nisposal (LET \& D) facility, where the overheads from this facility are discharged to the air and the bottoms (nitric acid) are recycled to either the tank farm or to the NWCF process.

The WC-114 evaporator, currently located in the old Waste Calcining Facility (WCF, CPP-633), will be replaced with a new evaporator system at CPP-604 in FY 1995 (High-Level Liquid Waste Evaporatur Upgrade; Fuel Processing Facilities Upgrade Task 12). 
Service Waste System - Service waste consists mainly of cooling water, steam condensate, demineralizer and boiler blow down wastes, and nonradioactive laboratory drain liquid. The service waste system discharges all liquid to one of two percolation ponds. A new waste treatment system, Liquid Effluent Treatment and Disposal (LET\&D Fuel Processing Facilities Upgrade Task 13), began operation in FY 1993. This process will further cleanup the PEW overhead and eliminate the need to transfer the condensate to the service waste system, thereby eliminating mixed liquid discharges to the percolation ponds.

Two separate systems, west side and east site, collect service waste from ICPP facilities. Service waste is monitored and directed to the PEW system for processing if radionuclide activity above set limits is detected. Diverted service waste is temporarily stored in WM-191, an aboveground carbon steel tank located at the north end of the tank farm.

New Waste Calcining Facility (CPP-659) - High-level liquid waste from the tank farm is processed through the NWCF (CPP-659) and converted to a granular solid called calcine. The conversion of high-level liquid waste to calcine results in an approximately seven to one reduction in volume. The NWCF processes an average of 3000gallons of high-level liquid waste per day of operation.

NWCF is a concrete and steel building measuring approximately 250 -feet long and 140 -feet wide. It extends 57-feet below grade and 43-feet above grade. Systems that process large quantities of radioactive material are located below grade. The building was designed using the functional isolation and modular concept; equipment for each functional process step is isolated within a major process cell. High failure rate equipment is placed in cubicles outside the cell to allow for easier remote maintenance or removal. The building houses the waste calcination process and support systems and the ICPP decontamination facility.

Bin Sets - Calcine, which is a mixed high-level radioactive waste, is stored in bin sets located to the east and south of NWCF. These bin sets consist of partially underground, vertical stainless steel bins contained within concrete vaults. Seven solids storage facilities (i.e., bin sets) have been constructed to date. The first five facilities have already been filled and the sixth is partially filled.

Off-Gas Cleanup and Atmospheric Protection System (CPP-649/756) - Gaseous wastes resulting from ICPP operations consist of process off-gas and ventilation air. Each major process has its own primary off-gas cleanup system for removing radioactive particulate materials from these gaseous wastes. The Atmospheric Protection System (APS) provides backup air filtering and treatment facilities for some of the ICPP processes. The process off-gas (POG) is handled separately from the ventilation air in the APS. Off-gas and ventilation air from the analytical laboratories are generally vented to the atmosphere through exhaust hoods and HEPA filters, which are located within the laboratory facility.

The APS system is located in two buildings, CPP-649 and CPP-756. These buildings are located immediately west of the CPP-604/605 complex. CPP-649, the APS HEPA filter building, is 77-feet long, 33-feet wide, and 26-feet high. It is constructed of reinforced concrete and is divided into two sections, the HEPA filter area and the off-gas cleanup area. CPP-756, the APS prefilter vault, measures 40 -feet long, 90 -feet wide, and 14-feet high. It shares a common wall with CPP-649.

CPP-756 contains equipment that filters potentially contaminated ventilation air from various plant facilities. NWCF and FAST both have APS systems for filtering ventilation air. Therefore, ventilation air from those two buildings is not routed to the CPP-649/759 APS system. 
The HEPA filter area of CPP-649 contains 26 filter caissons that receive the prefiltered ventilation air from CPP-756. After passing though the APS HEPA filter system, the ventilation air is discharged to the ICPP main stack. NOx-bearing off-gases are passed through an off-gas cleanup area in CPP-649. Blowers are used to exhaust this gas to the ICPP main stack after cleanup.

CPP-601 has five off-gas cleanup systems which provide vacuum and ventilation air for the various processes. These systems also serve CPP-604, CPP-627 and CPP-640. The NWCF and FAST facilities also have their own dedicated off-gas cleanup systems. The filtered FDP off-gas can be routed to the Rare Gas Plant in CPP-604 for krypton recovery or discharged directly to the FAST stack.

Fuel Storage Area (CPP-666) - This facility consists of six water-filled storage pools that are used to store Naval spent nuclear fuel and some aluminum clad fuel. It was constructed in 1984 and is the state of the art in terms of underwater spent fuel storage.

Fuel is stored in this facility in stainless steel racks (or aluminum racks for aluminum clad fuel) which contain the fuel and maintain the proper spacing for the fuel. All Naval fuel that is currently received at the ICPP is stored in this facility.

Fuel Storage Facility (CPP-603) - This is the original fuel storage facility at the ICPP. This facility consists of three water-filled basins, constructed in the 1950s, which are used to store a variety of spent fuels and a dry storage facility, constructed in the 1970 s, that is currently used to store spent graphite matrix fuel.

The underwater basins store fuel using two basic methods: Racks are employed in one of the basins that is similar to the CPP-666 storage method. In the other basins, yokes are supported from a monorail track. Each yoke has a bucket or a hook that holds individual units of fuel. Bumpers on each yoke maintain the proper spacing between the yokes for the safe storage of fuel. These basins are scheduled to have all fuel removed from them by the year 2000.

The dry storage area in CPP-603 stores spent graphite type fuel in a shielded cell. This system is being explored to store additional types of fuel that are suitable for storage in a dry environment.

Underground Fuel Storage Area (CPP-749) - This area consists of vaults that are in the ground which hold a quantity of spent fuel. The vault and ground provide the necessary shielding for the spent fuel elements. There are several "second generation" vaults which have not been used but are capable of storing spent fuel.

Radioactive Waste Management Complex (RWMC): The mission of the RWMC is to provide waste management for the present and future needs of the INEL to retrieve, examine, and certify stored TRU waste for ultimate shipment to the DOE Waste Isolation Pilot Plant (WIPP) in New Mexico; and to initiate and support research, development, and demonstration projects that will better enable the RWMC to manage waste in a manner that is cost-effective, safe for personnel, and safe for the environment.

The RWMC is a restricted area located 7 miles southwest of the Central Facilities Area. Currently 144 acres at RWMC are used for the actual disposal and storage of waste.

Process Experimental Pilot Plant (PREPP): The mission of the PREPP was to develop and demonstrate fullscale processes to reduce the volume, stabilize and destroy hazardous constituents in uncertifiable TRU, mixed, and TRU-contaminated LLW currently stored at the INEL. The PREPP is currently on standby status, awaiting disposition decisions. 


\section{IDAHO NATIONAL ENGINEERING LABORATORY}

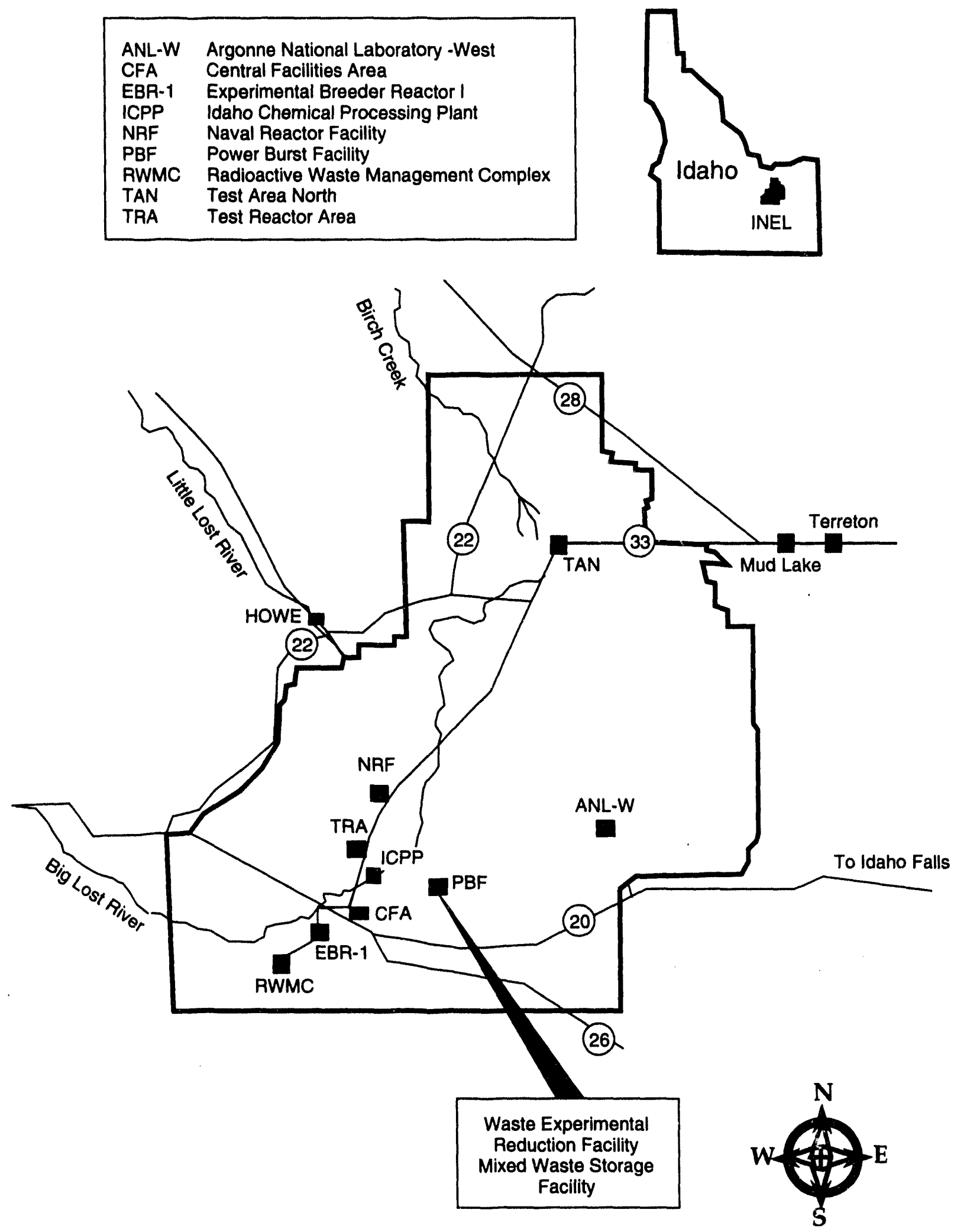




\section{WASTE EXPERIMENTAL REDUCTION FACILITY}
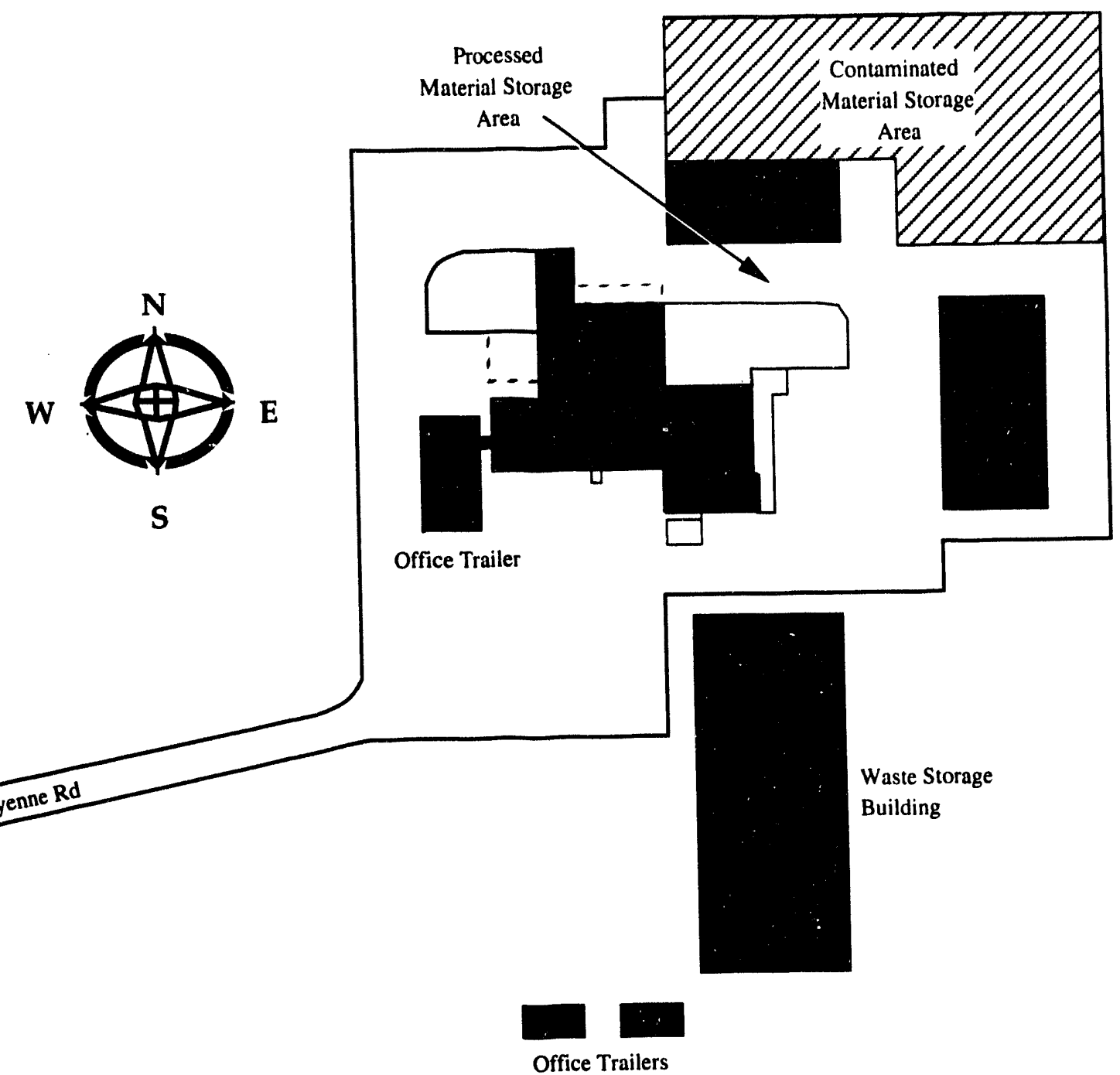

IDAHO NATIONAL ENGINEERING LABORATORY MIXED WASTE STORAGE FACILITY
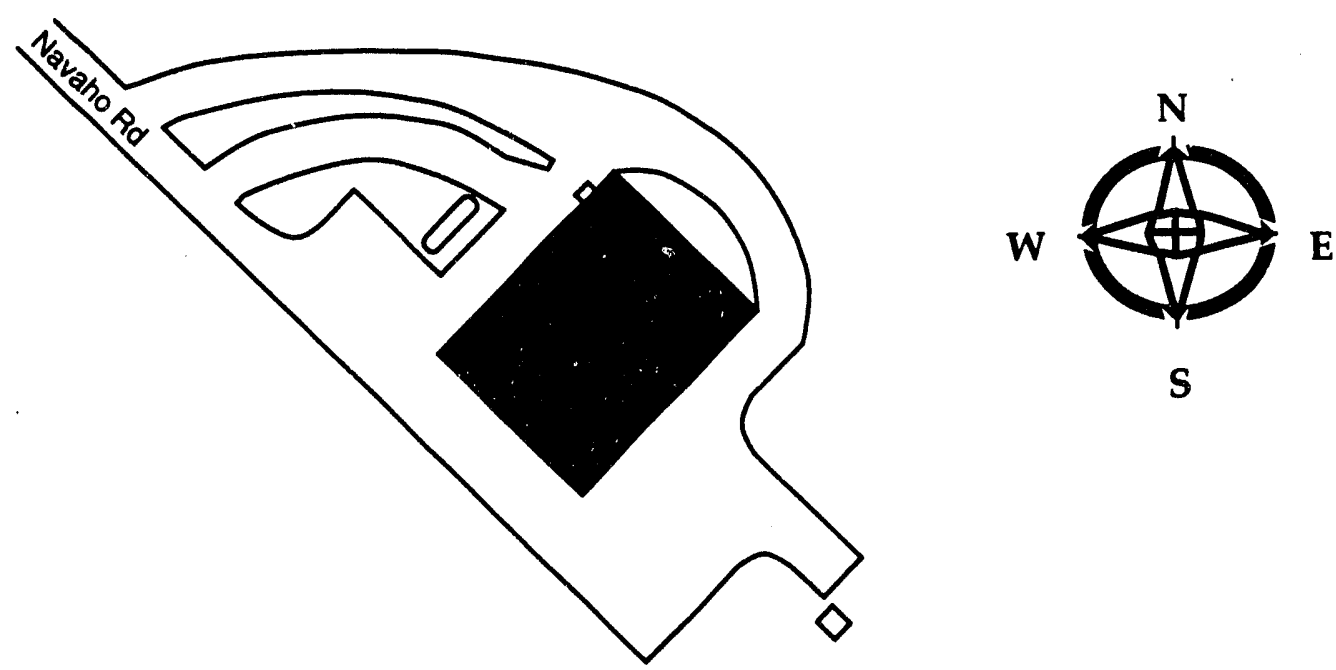


\section{IDAHO NATIONAL ENGINEERING LABORATORY ICPP TECHNICAL SITE INFORMATION}

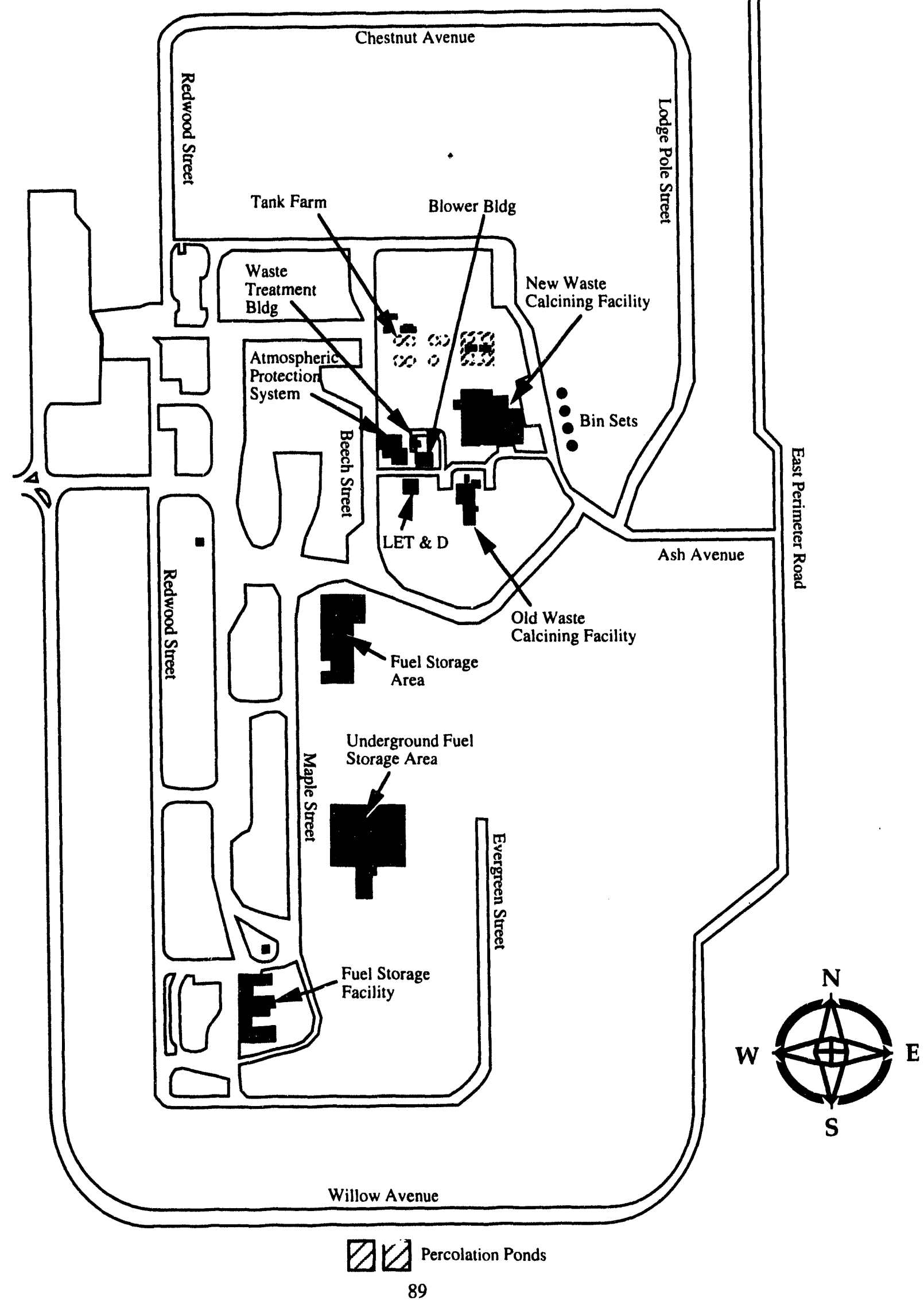




\section{IDAHO NATIONAL ENGINEERING LABORATORY}

RADIOACTIVE WASTE MANAGEMENT COMPLEX

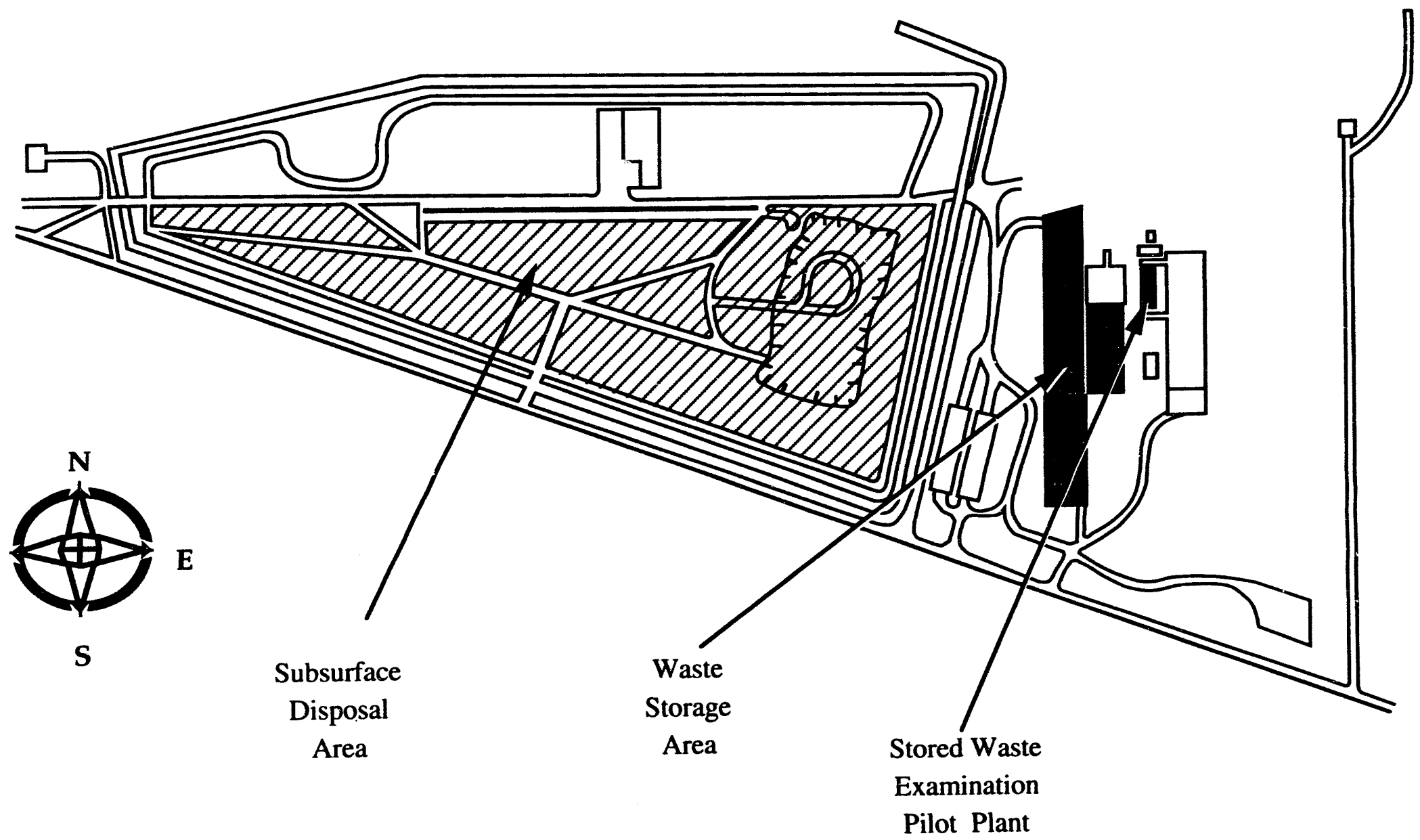




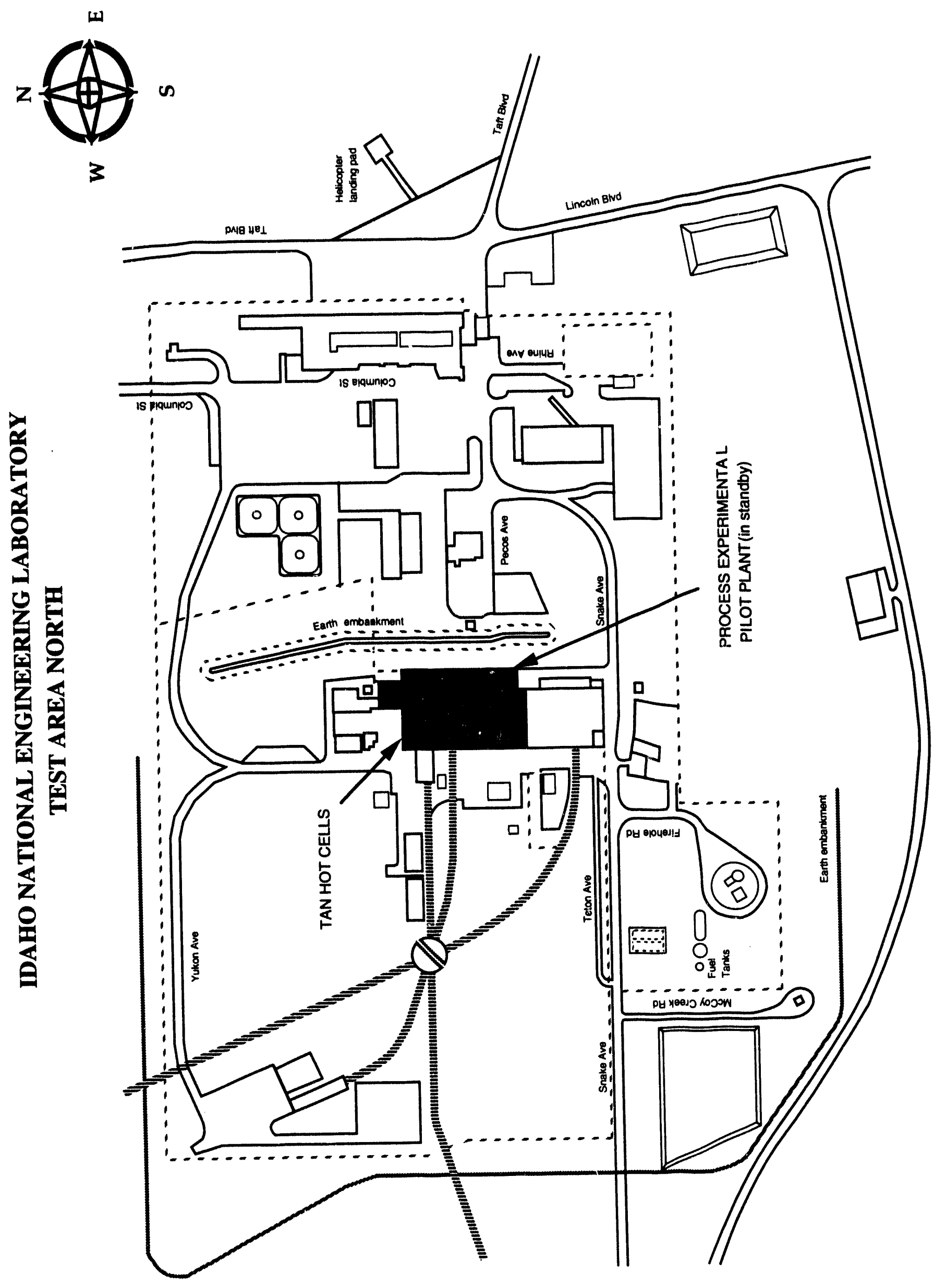




\section{WEST VALLEY DEMONSTRATION PROJECT OFFICE}

\section{ENVIRONMENTAL RESTORATION AND WASTE MANAGEMENT FACILITIES}

\section{DESCRIPTION}

The West Valley Demonstration Project (WVDP) is carried out at the Western New York Nuclear Service Center (WNYNSC) located in Cattaraugus County, near West Valley, New York. It occupies about 220 acres on the 3,300 acre site. The WVDP Act (PL 96-368) was enacted to demonstrate solidification that can be used to prepare high-level radioactive waste (HLW) for disposal. Waste management programs at the site include waste minimization, reduction, treatment, and storage. Other site activities include programs for site characterization, site cleanup, decontamination and decommissioning of facilities, and shipment of HLW to the repository. Currently the project is stressing continued waste management and waste cleanup in a safe and effective manner that protects the general public, plant employees, and the environment.

\section{AGREEMENTS}

Statute/Type

RCRA Consent Order

RCRA Federal and State

FacilityCompliance

Agreement

\section{Facilities}

WVDP

WVDP
Parties

DOE/EPA/NY

DOE/EPA/NY
Status

Completed 3/15/92

Completed 3/22/93

\section{FACILITIES AND PROJECTS}

The WVDP is responsible for demonstrating that solidification is a viable way to prepare HLW for disposal. The original facility reprocessed nuclear fuel from 1966 to 1972 . During that time, approximately 660,000 gallons of alkaline high-level waste and about 12,000 gallons of acidic THOREX waste were generated. A description of the facility follows:

- The LAG Storage Areas, which include Low-level and Transuranic Waste Storage areas and the Supercompactor Facility, provide waste classification assay equipment, a drum supercompactor, and weather-proof storage areas for packaged low-level and transuranic wastes generated from operation, decontamination, maintenance, and construction activities at the WVDP.

- The Waste Tank Farm contains four underground waste storage tanks. Two of these tanks contain the highly radioactive waste generated during fuel reprocessing. Tank 8D-2 contains approximately 660,000 gallons of alkaline high-level waste. Tank 8D-4 contains approximately 12,000 gallons of acidic THOREX high-level waste. Tanks 8D-1 and 8D-3 are spare tanks supporting Tanks 8D-2 and 8D-4, respectively. 


\section{FACILITIES AND PROJECTS (Continued)}

- The new Vitrification Facility will house the Vitrification System. The Vitrification System will be used to solidify into borosilicate glass the radioactive constituents in the high-level waste (HLW) presently stored in the Waste Tank Farm. The major functions of the Vitrification System are melter feed preparation, $\mathrm{HLW}$ vitrification, and filled canister handling and storage. The filled canisters will be transferred to the Chemical Process Cell after cooling and sealing.

- The offices house the project management, administrative and engineering offices, computer services, the emergency operations center, and the environmental monitoring laboratory.

- The lagoons are a peripheral part of the Low-Level Waste Treatment (LLWT) system and consist of one lagoon for storage of the unprocessed liquid waste and three lagoons for storage of the processed liquid wastes from WVDP activities.

- The Fuel Receiving and Storage (FRS) area was the point of entry for fuel assemblies coming into the plant for reprocessing. It contains the cask decontamination rooms, the cask unloading pool, a 90-ton capacity crane, the water-filled fuel storage pool, and the water cooling and water and air filtration systems. Current' ${ }^{\prime \cdot}$ an Environrnental Assessment is being prepared to determine available options for the long-term storage and disposal of the fuel.

- The Old Process Building contained the mechanical and chemical processing facilities for reprocessing operations. A portion of the building has been decontaminated to the extent necessary to house the Analytical Laboratory, the Mass Spectroscopy Laboratory, vessel off-gas treatment equipment, offices, the process plant ventilation supply and exhaust, and parts of the liquid waste treatment system. The Old Process Building also houses the utility room which services the steam, water, and electrical needs of the site; this room contains a diesel generator, an emergency diesel generator, boilers, plant air compressors, and plant cooling water and utility water pumps. The decontaminated Chemical Process Cell will be used as an interim storage facility for the solidified high-level waste glass canisters. The remainder of the Old Process Building remains essentially the same as when reprocessing operations took place.

Decontamination and decommissioning of these areas will be addressed in the Phase II Environmental Impact Statement.

- The New York State Licensed Disposal Area (SDA) occupies 22 acres near the middle of the Western New York Nuclear Service Center site. This burial area was used between 1963 and 1975 for the disposal of solid wastes with relatively low levels of radioactivity; the waste came from hospitals, laboratories, industrial facilities, nuclear reactors, and the Nuclear Fuel Services reprocessing plant.

- The Nuclear Regulatory Commission Licensed Disposal Area (NDA) occupies 7.2 acres adjacent to the SDA. This area was used during old plant operations to bury wastes generated during reprocessing operations. Early in WVDP life, a small amount of Class A waste was buried in the NDA, but this practice was stopped due to an out-of-court settlement (Stipulation of Compromise) in 1987.

- Two warehouse storage facilities are used on site. The main warehouse is the central shipping and receiving area for all nonradioactive materials. The second facility, the Bulk Storage Warehouse, is presently used for long-term storage of large items.

- A shielded Drum Cell Facility has been constructed for storage of low-level waste drums. Currently, 14,470 drums are being stored; the Drum Cell Facility has a capacity of 19,325 drums. These square drums are stacked remotely using a computerized crane system. 


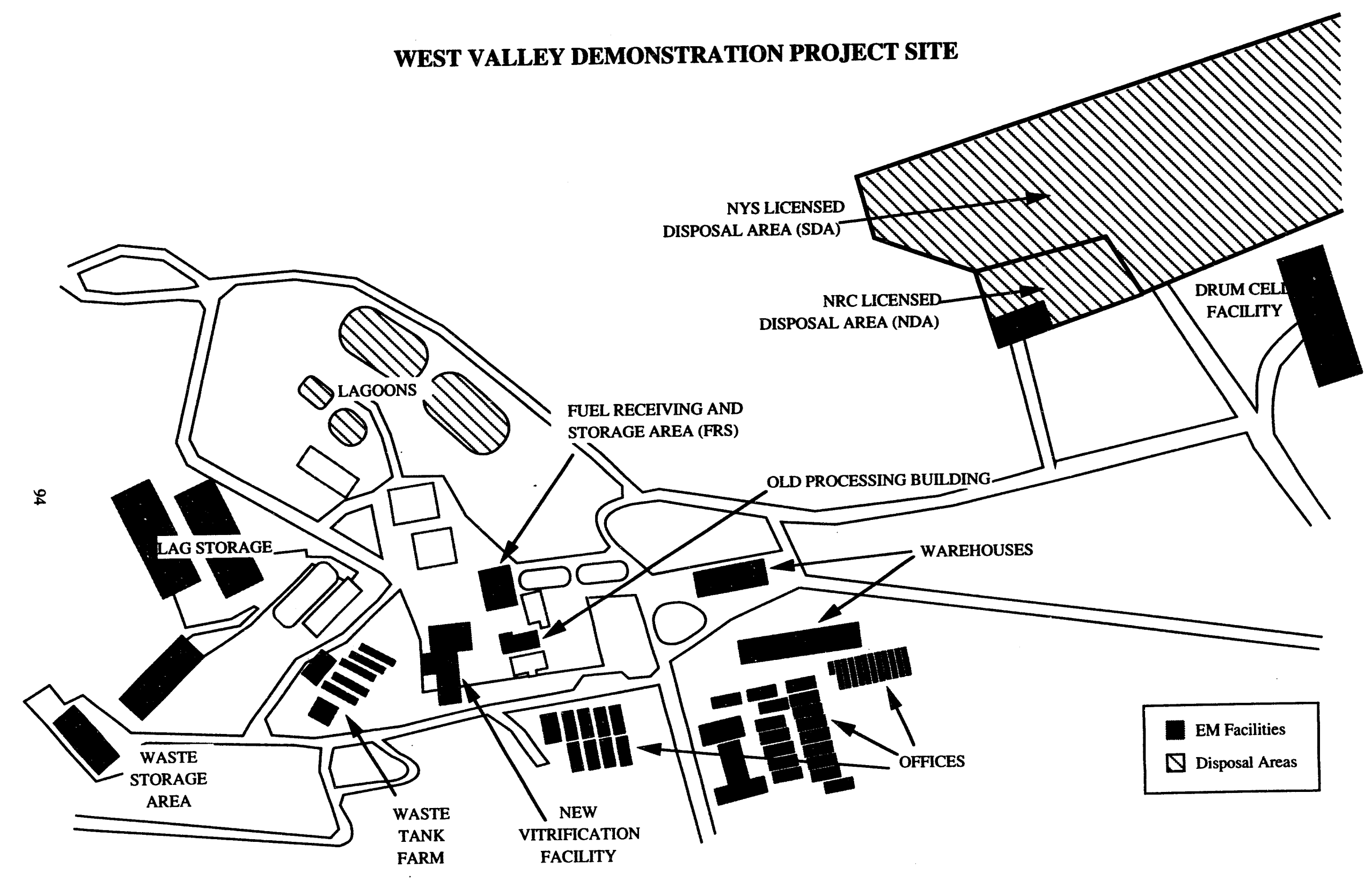




\section{NEVADA OFF-SITE LOCATIONS}

\section{ENVIRONMENTAL RESTORATION AND WASTE MANAGEMENT FACILITIES}

\section{DESCRIPTION}

Nevada Field Office (NV) manages eight off-site [i.e., off-Nevada Test Site (NTS)] locations that were used primarily for underground nuclear effects tests and experiments. The purpose of the tests conducted at these sites was to study the potential for gas field stimulation and studies related to underground nuclear test effects and warhead development. These sites are located at Amchitka Island, Alaska; the Rio Blanco and Rulison test locations near Grand Valley and Rifle, Colorado; the Gasbuggy and Gnome-Coach gas stimulation test sites near Carlsbad and Farmington, New Mexico; the Salmon Site near Hattiesburg, Mississippi; the Shoal Test Area near Fallon, Nevada; and the Central Nevada Test Site near Tonopah, Nevada. The closest site to a major population center is the Salmon Test Site, which is located 21 miles southwest of Hattiesburg, Mississippi. Pending further clarification as part of the planned negotiations with the five host States, NV considers CERCLA to be the primary regulatory authority governing any remediation of the sites.

\section{AGREEMENTS}

\section{Statute/Type}

Agreement-in-Principle
Facilities

Shoal Test Site

Faultless Test Site
Parties

Status

DOE/NV

Completed 10/4/90

\section{FACILITIES AND PROJECTS}

Under the Environmental Restoration Program, the Nevada Operations Office will characterize contaminant sources and contamination at each of the following off-site locations, determine the risks associated with each site, and implement remedial actions, as appropriate.

\section{Amchitka Island, Alaska}

Amchitka, the southernmost island of the Rat Island Group in the Aleutian chain, was the site of three nuclear detonations.

Longshot was an $80 \mathrm{KT}$ nuclear test detonated on October 29, 1965, at a depth of 2300 feet in volcanic rock and was part of the Vela program, to obtain event measurements relating to the detection of underground nuclear detonations.

Milrow was a one MT seismic calibration test detonated on October 2, 1969, at a depth of 4000 feet in volcanic rock.

Cannikan was a five MT test of the proposed warhead for the Spartan missile. It was detonated at a depth of approximately 5875 feet on November 6.1971 , in volcanic rock. 
Site deactivation and roll-up was started in February 1972, and completed in September 1973.

Amchitka is owned by the Department of Interior (DOI) and managed by the U.S. Fish and Wildlife Service (FWS). Portions of Amchitka bear secondary designations such as national wilderness area and a military reservation.

Custody of all surface facilities and structures were turned over to the FWS when the roll-up was complete in 1973. The Navy has taken over and rebuilt or replaced most of the buildings and facilities and are using the island for an "Over-the-Horizon" radar site.

The AEC [now U.S. Department of Energy (DOE)] has no responsibility for any of the facilities currently on Amchitka.

\section{Rio Blanco. Colorado}

Project Rio Blanco was a joint Government-Industry (CER Geonuclear Corporation) experiment to determine if nuclear explosives could be used to stimulate the production of natural gas. Three 30-kiloton nuclear devices were simultaneously detonated on May 17,1973, at depths of 5339, 6230, and 6690 feet, in a tight sandstone rock formation.

The experiment site in northwestern Colorado is 36 miles northwest of Rifle and approximately 52 air miles north of Grand Junction, CO.

Site restoration work was performed during the summer and fall of 1976.

Public land surface and subsurface rights to the emplacement well (RB-E-01) area and the flare stack site are administered by the Bureau of Land Management (BLM). Surface rights to the alternate re-entry well RB-U-4 and Fawn Creek Government No. 1 well areas are held by a private land owner, while the subsurface rights to these areas are held by the Federal government. These land right determinations have been established by Public Land Order 5344.

All surface facilities have been removed from the site. All excavations and ditches, not required for permanent surface drainage, have been filled. The Atomic Energy Commission (AEC)-built roads were left in their as-is condition for take over by Rio Blanco County or the BL.M. The topsoil was sloped and the land surface was returned to its natural state.

\section{Rulison, Colorado}

Project Rulison was a joint Government-Industry (Austral Oil Company) gas stimulation experiment conducted on September 10, 1969, in a sandstone rock formation. A 40-kiloton nuclear device was emplaced at a depth of 8426 feet for the purpose of increasing production in a tight natural gas formation.

The experiment site is in northwestern Colorado about six miles southeast of the town of Grand Valley and 14 miles southwest of Rifle, CO.

Site cleanup work was carried out in the summer of 1972.

Surface rights were negotiated with a deed between the U.S. Government and the official landowner, Lee Hayward. These surface rights were later sold after clean-up and now belong to a private party. The subsurface rights are controlled by the government to exercise limited drilling activity below 6000 feet. 
A 150 foot by 150 foot fenced area with a locked gate, erected by the landowner, encircles the ground zero monument with a camping trailer nearby. Telephone and electrical power lines were left in place at the request of the Rulison landowner.

All other surface facilities were removed from the site during the site clean-up operation in July 1972.

\section{Gasbuggy. New Mexico}

Project Gasbuggy was a gas stimulation experiment. A $29 \mathrm{KT}$ nuclear device was detonated on December 10, 1967, at a depth of 4240 feet in a sandstone rock formation.

The site is located about 55 air miles east of Farmington, NM, and 20 miles southwest of Dulce, NM.

Demobilization work was performed during August and September of 1978.

Through a memorandum of understanding between the U.S. Forest Service and the U.S. Atomic Energy Commission (AEC), the AEC acquired rights to use the land for testing purposes. The Bureau of Land Management (BLM) withdrew the land from all forms of public use on June 22, 1967.

Surface and subsurface operating rights to lands within the SW quarter of the described site location were reserved for the use of the Atomic Energy Commission.

After site cleanup and restoration, the land was returned to the BLM and the U.S. Forest Service (USFS) for unrestricted use of the land surface, however, drilling and excavation restrictions were imposed.

The perimeter fence and all other above-ground facilities have been removed from the site. All excavations were backfilled and the ground surface was graded to natural contours and reseeded with a grass mixture developed by the U.S. Forest Service.

\section{Gnome. New Mexico}

Project Gnome was the first underground Plowshare program event to take place outside the Nevada Test Site (NTS). It was detonated at a depth of 1184 feet in a salt bed on December 10, 1961, and had a nuclear yield of $3.1 \mathrm{KT}$.

The site is located approximately 30 miles southeast of Carlsbad, NM.

Site cleanup took place during 1968-1969 with a follow-up cleanup during the summer of 1979 .

The 680 acres of operating area for the Gnome Project were withdrawn from public domain by the Bureau of Land Management (BLM) in October, 1959, and assigned to the Atomic Energy Commission (AEC) for conducting the nuclear experiment.

After final cleanup of the site in September 1979, the surface and all remaining surface facilities were returned to the custody of the BLM.

All other surface facilities were removed from the site and the land was restored to its natural condition. 


\section{Salmon Test Site. Mississippi}

The Salmon Site was used for two nuclear detonations, Salmon and Sterling; and two nonnuclear gas detonations. These tests were used for seismic decoupling studies carried out as a part of the Vela Uniform program. Salmon was conducted at a depth of 2717 feet in the domed salt structure on October 22, 1964, and had a yield of 5.3 KT. The Sterling device was suspended in the 55 foot radius cavity formed by the Salmon detonation and was detonated on December 3, 1966, with a yield of 380 tons. The two methane-oxygen explosions, also conducted in the Salmon cavity, were detonated on February 2, 1960, and April 19, 1960.

The Salmon Site, approximately one mile in diameter is located in south central Mississippi. Following testing, there was a cleanup operation that included soil excavation and disposal, groundwater recovery, and decommissioning of facilities. The site was deactivated and decommissioned in mid-1972.

The area encompassing the Salmon Site experiments was assigned to the Atomic Energy Commission (AEC) through an agreement with the Tatum Lumber Company; and, with the completion of the project and site restoration, the land was returned to the lumber company.

Major roads on the site were left undisturbed. All surface facilities have been removed or ownership transferred to the landowner. The perimeter of the area is fenced. All work on site was halted at beginning of May 1993 because temporary access agreement expired. The DOE is in the process of purchasing the surface rights from the private landowner.

\section{Shoal. Nevada}

Project Shoal was a part of the Vela program to obtain event measurements relating to the detection of underground nuclear detonations. A $12 \mathrm{KT}$ nuclear explosive was detonated at a depth of 1211 feet on October 26, 1963, in granite rock.

The site is located approximately 28 miles southeast of Fallon, NV.

Site deactivation and roll-up was started in October 1963, and completed at the end of January 1964.

A land area around the designated test location was withdrawn by the Bureau of Land Management (BLM) from public domain in September 1962 and assigned to the exclusive use of the Atomic Energy Commission (AEC).

The Shoal site was returned to the BLM in 1970.

All surface facilities have been removed from the site. All excavations and ditches, not required for permanent surface drainage, have been filled.

The top-soil was sloped away from the emplacement shaft and drill holes and the land surface was returned to its natural state. 
Project Faultless was a one megaton seismic calibration test detonated on January 19, 1968, at a depth of 3200 feet in Drill Hole UC-1 in central Nevada in tuffaceous sediment and zeolitized tuff.

The site is in Hot Creek Valley between Tonopah and Ely in Nye County, Nevada.

Demobilization work was performed during the summer and fall of 1973.

The test area consisted of approximately 20 separate properties obtained from the Bureau of Land Management (BLM). The BLM withdrew the land from public use during 1968 and 1969. A total of about 2560 acres was involved.

After site cleanup and restoration, some of the land was returned to the BLM for unrestricted use by the general public. Areas which contain large diameter emplacement holes which were not used are still retained by DOE.

All major roads constructed by the Atomic Energy Commission were left in their as-is condition for take-over by Nye County or the BLM. Underground pipelines and telephone cables were abandoned in place. All miscellaneous materials and debris were removed from the surface of the site and disposed of in an approved manner.

The communications repeater stations were left in place and continue to be used in support of DOE operations. All other facilities were removed and the land was restored to its natural condition. 
NEVADA OFF-SITE LOCATIONS

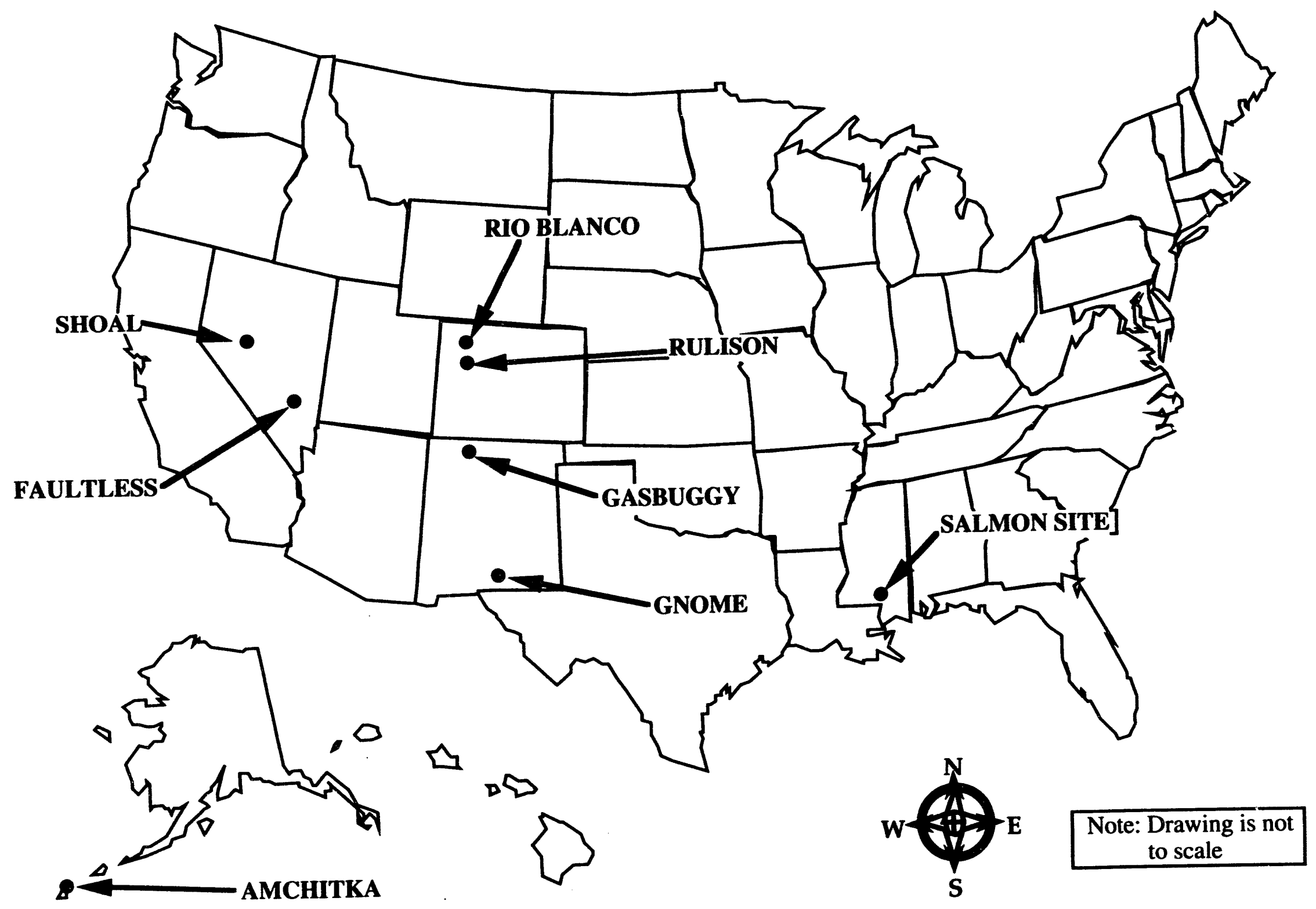




\section{NEVADA TEST SITE}

\section{ENVIRONMENTAL RESTORATION AND WASTE MANAGEMENT FACILITIES}

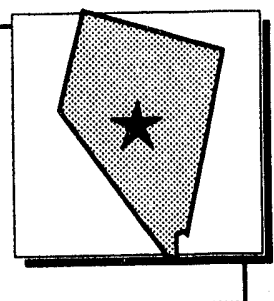

\section{DESCRIPTION}

Nevada Operations Office (NV) operates the Nevada Test Site (NTS) and historical test areas on the Tonopah Test Range (TTR) and Nellis Air Force Range (NAFR) Area 13. NTS covers approximately 1350 square miles of desert. The closest major population center is Las Vegas, about 65 miles southeast of NTS. The primary use of NTS has been for belowground nuclear tests and, historically, aboveground nuclear tests. Approximately 800 individual contamination sites have been identified that include the belowground and aboveground testing locations, ancillary waste disposal sites associated with testing activities, and areas where surficial soils were contaminated with plutonium as a result of safety tests of nuclear devices. Pending further regulatory clarification by the EPA, NV considers CERCLA to be the primary regulatory authority governing any remediation of the sites. For active tunnel ponds and muckpiles that receive waste generated during operations following nuclear tests, RCRA may be the primary regulatory authority. NTS has designated areas for disposal of low-level waste and transuranic waste.

\section{AGREEMENTS}

Statute/Type

Agreement-in-Principle

RCRA/Mixed TRU Waste

Storage
Facilities

NTS

NTS
Parties

DOE/NV

$\mathrm{DOE} / \mathrm{NV}$

\section{Status}

Completed 10/4/90

Completed 6/23/92

\section{FACILITIES AND PROJECTS}

\section{AREA 3}

U3ahat

U3ahat is the active disposal cell at the Area 3 Radioactive Waste Management Site (RWMS). It currently accepts off-site waste from the Fernald Environmental Management Pioject in Fernald, Ohio. U3ahat was created from two adjacent subsidence craters, U3ah and U3at, with a combined original volume of approximately nine million cubic feet.

\section{$\underline{\text { U3axbl }}$}

U3axbl is an inactive disposal cell awaiting closure. U3axbl contains mixed waste (MW) due to the presence of lead in the waste disposed in the cell during the past. Disposal was discontinued in January 1988. A closure plan for U3axbl has been submitted to the State of Nevada. 


\section{Support Facilities}

Two office trailers are located at the Area 3 RWMS. They are used as office space for maintaining records and for the storage of necessary survey instruments. These buildings consist of 2720 square feet of transportainer type structures.

\section{AREA 5}

\section{Waste Processing Facility}

Building 5-6, located at the Area 5 RWMS, has the approximate dimensions of $40^{\prime} \mathrm{X} 60^{\prime}$ with a metal exterior. This building contains offices, a waste compactor, and a storage room for tools, radiological survey equipment and protective clothing.

\section{RWMS Office}

Building 5-7, located at the Area 5 RWMS, has the approximate dimensions of $60^{\prime} \mathrm{X} 63^{\prime}$, with a metal exterio'. This building contains the usual office equipment in addition to laboratory equipment which includes spectroscopy equipment and gas chromatographs.

\section{Portal Monitor Building}

Building 5-10, a trailer located at the Area 5 RWMS, has the approxinate dimensions of $12^{\prime} X 32^{\prime}$. This building is not equipped with sewer or water. This building has two Tenelecs and one threshold monitor.

\section{Craft Lunch Room/Shack}

Building 5-18, located at the Area 5 RWMS, has the dimensions $8^{\prime} \times 40^{\prime}$. This structure is a metal transportainer and is not equipped with sewer or water. This building has a refrigerator, a microwave oven, and a table with some chairs.

\section{Storage and Maintenance Shed}

Building 5-21, located at the Area 5 RWMS, has the dimensions $20^{\prime}$ X 50'. This structure is a lean-to type shed and is not equipped with any utilities.

\section{Pit 4}

Pit 4 is used for the disposal of currently approved generators' low-level waste (LLW). Pit 4 was opened on June 21,1988 and is approximately one-half full. It has a depth of 20 feet and is 1000 feet long and 200 feet wide.

\section{Trench 3}

Trench 3 is open and reserved for the disposal of LLW containing asbestos. It is approximately 630 feet long, 45 feet wide, and 15 feet deep.

\section{Trench 8}

Trench 8 is an open trench reserved for LLW disposal. This trench will be used when Pit 4 has reached capacity. It is approximately 630 feet long, 100 feet wide, and 24 feet deep. 


\section{Trench TO2C}

Trench TO2C was opened in May of 1988 and is reserved for classified LLW disposal. It is approximately 254 feet long, 60 feet wide, and 20 feet deep.

\section{Trench TO4C}

Trench TO4C was opened in May of 1969 and is reserved for the disposal of classified MW. It is approximately 1133 feet long, 41 feet wide, and 20 feet deep.

\section{Pit 3}

Pit 3 was opened in January 1987 and granted interim status by the State of Nevada in September 1987. MW was received under the interim status provision until May 4, 1990. This pit is approximately 1050 feet long, 346 feet wide, and 30 feet deep. Pit 3 has approximately four million cubic feet of remaining disposal capacity. An Environmental Assessment (EA), required by the National Environmental Act (NEPA), for the continued operation of Pit 3 was prepared and a Finding of No Significant Impact (FONSI) issued.

\section{Mixed Waste Management Unit (Proposed)}

In 1988, DOE submitted a Part B Permit application to the State of Nevada for a new mixed waste management unit at the Area 5 RWMS. The State issued completeness review comments requiring additional site characterization data and a reduction in site size. Revision to the Part B Permit application and site characterization activities are ongoing.

\section{Hazardous Waste Accumulation Site (HWAS)}

The Hazardous Waste Accumulation Site consists of an impervious concrete pad with six-inch curbs to contain spillage as well as protect the pad from precipitation run-on and run-off. The HWAS provides separate curbed areas for the accumulation of noncompatible wastes. The facility has a roof to protect the wastes from precipitation and weathering effects, and a fire detection system.

\section{Transuranic Waste Storage Pad (WSC)}

Since 1974, the Area 5 RWMS has received TRU wastes from LLNL for storage. These wastes are being stored pending opening of the Waste Isolation Pilot Plant (WIPP). The WSC consists of a curbed asphalt pad. The current volume of TRU is approximately 600 cubic meters ( 1600 barrels and 57 boxes).

\section{Greater Confinement Disposal (GCD)}

GCD boreholes are used for disposal of low-level radioactive wastes considered unsuitable for near surface disposal. These wastes include those with high levels of environmentally mobile radionuclides or wastes with high external radiation levels. Each borehole is 3.0 meters in diameter and 37 meters deep. Approximately 15 meters of waste may be emplaced in a GCD hole which is then backfilled with 21 meters of soil. A 1.8 meter long concrete monument indicating the location and content of the hole is used to mark the center of each GCD hole. Of the $13 \mathrm{GCD}$ holes constructed, six have been temporarily closed. 


\section{Strategic Materials Storage Yard}

Since 1987, Strategic materials have been stored at the Strategic Materials Storage Yard in metal transportainers on a pad adjacent to the northeast corner of the Area 5 RWMS.

\section{AREA 15}

EPA Farm

Building 15-06 was utilized for environmental uptake studies. Presently the facility is being used on an intermittent basis for various other activities. Building 15-06 is a 1 floor building, 13 feet high, 60 feet in length and 40 feet wide, and constructed primarily of steel.

\section{AREA 23}

\section{Building 23-132}

Building 23-132 is located in Mercury, Nevada, off Ranger Avenue. It currently houses Waste Management Department (WMD) computer operations, support personnel, and the Special Projects Section office.

\section{AREA 25}

\section{E-MAD}

Building 3900 was utilized for the Nuclear Rocket Developinent Program. Presently $40 \%$ of the building is being utilized for warehouse storage. Building 3900 has three levels and is 60 feet in height, 180 feet length, and 144 feet wide. It consists primarily of reinforced concrete and steel.

\section{Test Cell “A"}

Building 3124, Equipment Test and Maintenance Lab, (Test Cell "A") was utilized for the Nuclear Rocket Developmicnt Program and has recently been converted for use in bench scale testing for soil/plutonium separation work. Building 3124 has one level and is 13 feet two inches in height, 70 feet in length, and 56 feet wide. It consists primarily of block/brick.

\section{Test Cell "A"}

Building 3113 was utilized for the Nuclear Rocket Development Program. Currently it has no use and is inactive. Building 3113 has one level and is 20 feet in height, 60 feet in length, and 40 feet wide. It consists primarily of reinforced concrete.

\section{Test Cell "C"}

Building 3210 was utilized for the Nuclear Rocket Development Program. Presently the facility is inactive and has no future usage. Building 3210 has three levels and is 36 feet in height, consisting of 24 feet above grade and 12 feet below grade. It is 72 feet in length and 59 feet wide. It consists primarily of reinforced concrete. 


\section{R-MAD}

Building 3110 was utilized during the Nuclear Rocket Development Program. Currently the cold storage bays are being used for warehouse storage. Building 3110 has three levels, and is 30 feet in height, 158 feet in length, and 119 feet wide. It consists primarily of reinforced concrete and steel.

\section{Jr. Hot Cell}

Building 3161 was utilized during the Nuclear Rocket Development Program. Currently the facility is inactive. Building 3161 has one level and is 12 feet in height, 20 feet in length, and 12 feet wide. It consists primarily of reinforced concrete.

\section{AREA 26 \\ Pluto Facility}

Building 2201 was utilized for the Tory 2TC Rocket Program started in 1962. Currently the facility is being used for storage and other activities. Building 2201 has two levels and is 30 feet in height, 159 feet in length, and 143 feet wide. It consists primarily of reinforced concrete and block/brick.

\section{AREA 27}

\section{Super Kukla}

Building 5420 was used as a Fast Burst Reactor facility. Currently the facility is inactive and not in use. Building 5420 has two levels and is 27 feet in height, 44 feet in length, and 24 feet wide. It consists primarily of reinforced concrete and steel. 


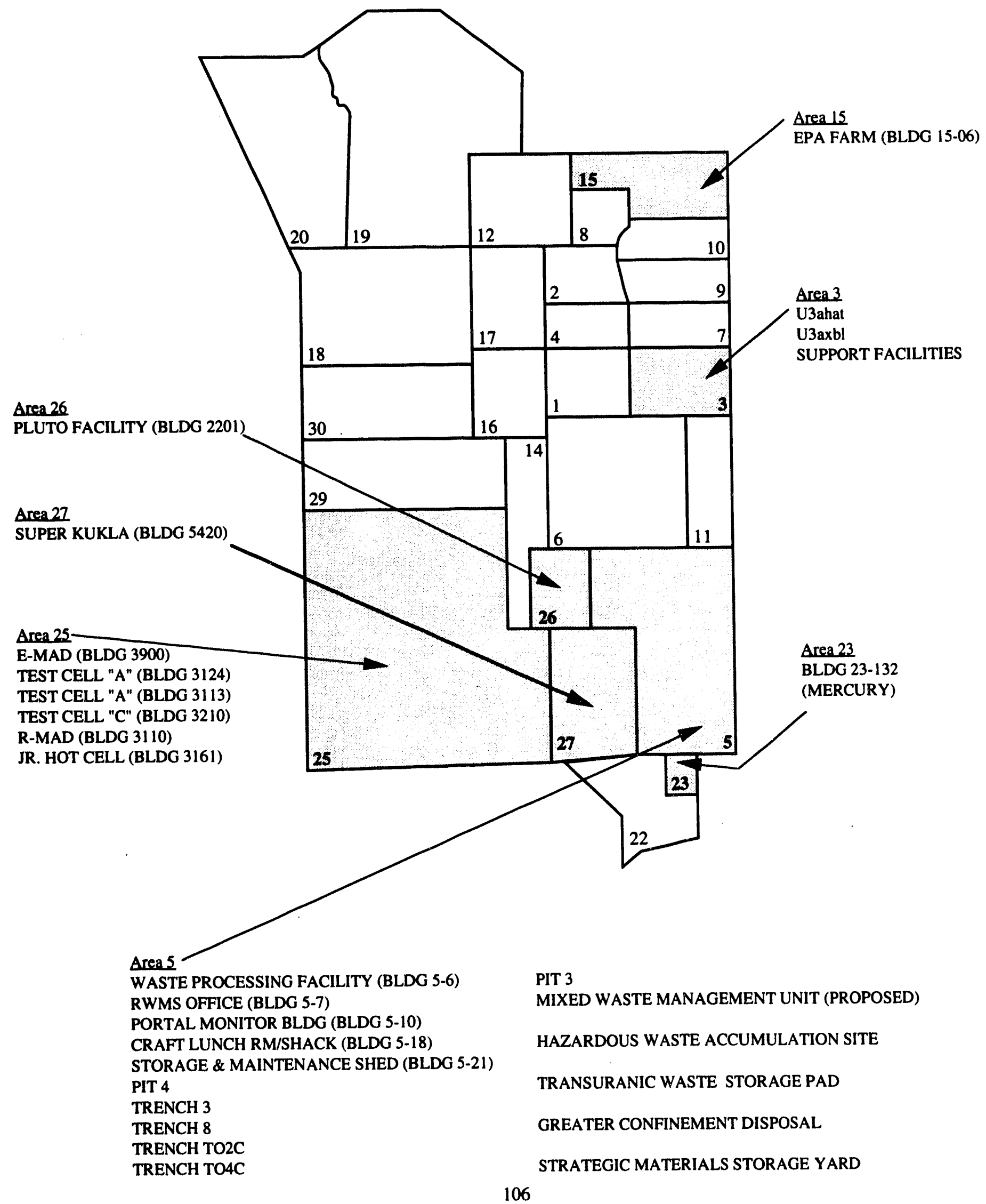




\section{FORMERLY UTILIZED SITES REMEDIAL ACTION PROGRAM \\ ENVIRONMENTAL RESTORATION AND \\ WASTE MANAGEMENT FACILITIES}

\section{DESCRIPTION}

During the 1940s, 1950s, and 1960s many sites in the United States were used by the Manhattan Engineer District (MED) and the Atomic Energy Commission (AEC) for processing and storing uranium and thorium ores. Some of these sites were owned by the Federal government; others were owned by universities or other institutions; and still others were privately owned, such as chemical plants.

As a result of those operations and the nature of subsequent cleanup activities, trace amounts of radioactive materials remain at some of the sites. Due to building demolition, construction, and erosion, some of the radioactive residues have been mixed with large quantities of soil and rubble. This has resulted in a large quantity of soil that is slightly contaminated.

Most of the sites were decontaminated and released for other uses under the regulations in effect at the time operations ceased. Subsequently, as radiological guidelines became more stringent, a number of sites were found to have residual contamination exceeding the revised guidelines.

To assess these sites and take appropriate remedial action, the Federal government initiated the Formerly Utilized Sites Remedial Action Program (FUSRAP) in 1974. FUSRAP is managed by the U.S. Department of Energy (DOE), a successor agency to the AEC.

The program presently includes 44 sites in 14 states. Of these, 39 are former MED or AEC sites that are included in FUSRAP under authority of the Atomic Energy Act of 1954 as amended. The other five sites were added by Congressional action in 1984 and 1985. Six of the sites are listed on the Environmental Protection Agency's National Priorities List (NPL). To date, DOE has completed remedial action on 13 sites, and an additional 12 sites are partially remediated. The tentative completion date is 2016 . Total estimated cost is $\$ 2.5$ billion.

\section{AGREEMENTS}

\section{Statute/Type}

CERCLA/Federal Facilities

Agreement

CERCLA/Federal Facilities

Agreement

CERCLA/SARA/RCRA/

Federal Facilities Agreement
Facilities

Maywood Interim

Storage Site

Wayne Interim

Storage Site

St. Louis and

Hazelwood, MO
Parties

DOE/EPA

Status

Completed 9/17/90

DOE/EPA

Completed 9/17/90

DOE/EPA

Completed 6/26/90 


\section{FACILITIES AND PROJECTS}

\section{University of California}

Gilman Hall is located on the University of California-Berkeley campus. Only the third floor and basement areas were associated with MED activities. Remedial action of all FUSRAP-related radiological contamination was completed in FY 1982.

\section{Seymour Specialty Wire}

The Seymour Specialty Wire site in Seymour, Connecticut, is located on Franklin Street along the west side of the Naugatuck River and just north of Route 67. Remedial action of all FUSRAP-related radiological contamination was completed in FY 1993.

\section{National Guard Armory}

Illinois National Guard Armory, located at 52nd Street and Cottage Grove, Chicago, Illinois, was leased by the Manhattan Project for storage and limited metallurgical work in the 1940s. Remedial action of radiological contamination was completed in FY 1988.

\section{University of Chicago}

In Illinois, the University of Chicago buildings associated with MED work were the new Chemistry Laboratory and Annex, West Stands, Ryerson Physical Laboratory, Eckhart Hall, Kent Chemical Laboratory, Jones Chemical Laboratory, and Ricketts Laboratory. Remedial action of radiological contamination was completed in FY 1988.

\section{W.R. Grace and Company}

W.R. Grace and Company, Davison Chemical Division, Curtis Bay, Maryland, conducted AEC work in one building at this 260 -acre facility, and the wastes were buried in a landfill-type area covering about four acres. To date, no remedial investigation or remedial action has been conducted at the site.

\section{Shpack Landfill}

The former Shpack Landfill covers about eight acres, and is located in the towns of Norton and Attleboro, Massachusetts.

\section{Ventron}

The Ventron Site, located in Beverly, Massachusetts, is currently operated by Morton-Thiokol Corporation, Ventron Division (formerly Metal Hydrides Corporation). Three buildings at the site were used in support of AEC uranium work.

\section{General Motors}

The General Motors site, located at 1450 Beecher Street, Adrian, Michigan, was formerly owned by the Bridgeport Brass Company. 


\section{Latty Avenue Properties}

The Latty Avenue Properties, Hazelwood and Berkeley, Missouri, located approximately one kilometer north of the St. Louis Airport, include the Hazelwood Interim Storage Site (HISS) and vicinity properties.

\section{St. Louis Airport Site (SLAPS)}

The St. Louis Airport Site (SLAPS), located in Hazelwood and Berkeley, Missouri, is a 21.7-acre tract located about 24 kilometers from downtown St. Louis, and adjacent to the northern boundary of the Lambert-St. Louis International Airport.

\section{SLAPS Vicinity Properties}

The SLAPS Vicinity Properties, St. Louis, Missouri, consist of former transport roads and approximately 70 adjacent vicinity properties.

\section{St. Louis Downtown Site (SLDS)}

The St. Louis Downtown Site (SLDS) facility is located in the eastern part of St. Louis, Missouri, at the intersection of North Broadway and Destrehan Streets. The site occupies about 45 acres and is currently owned and operated by Mallinckrodt, Inc.

\section{DuPont and Company}

The E.I. DuPont de Nemours and Company site is located in Deepwater, New Jersey. To date, no remedial action has been completed at the site.

\section{Kellex/Pierpont}

The Kellex Corporation site is located at the intersection of New Jersey Route 440 and Kellogg Street in Jersey City, New Jersey. Remedial action of radiological contamination was completed in FY 1981.

\section{Maywood}

The Maywood Site comprises properties in the boroughs of Maywood and Lodi, New Jersey, and the township of Rochelle Park that were contaminated by thorium processing at the Maywood Chemical Works. An 11.7 acre portion of the site, known as the Maywood Interim Storage Site (MISS) is used to store contaminated materials from cleanup of vicinity properties.

\section{Middlesex Municipal Landfill}

The former Middlesex Municipal Landfill Site, Middlesex, New Jersey, consists of approximately three acres of a 37-acre unimproved landfill. Remedial action of radiological contamination was completed in 1986.

\section{Middlesex Sampling Plant}

The former Middlesex Sampling Plant includes six buildings on 9.6 acres located just off Mountain Avenue in Middlesex, New Jersey. 


\section{New Brunswick Site}

The New Brunswick Site is the location of the former site of the New Brunswick Laboratory in New Brunswick, New Jersey. The site was used as a standards laboratory for the official assay of nuclear and nonnuclear materials used in the reactor and weapons programs.

\section{Wayne/Pequannock}

The 6.4-acre Wayne site, including the Wayne Interim Storage Site (WISS), is located at 868 Black Oak Ridge Road, about 1.2 miles east of Pompton Plains, and about 1.9 miles north of the town of Wayne in northeastern New Jersey. Contamination at the site and on several vicinity properties originated from commercial thorium processing started in 1946.

\section{Acid/Pueblo Canyon}

Acid and Pueblo Canyons, Los Alamos, New Mexico, was the location of the TA-45 waste treatment plant. Remedial action of the radiological contamination was completed in FY 1982.

\section{Bayo Canyon}

The Bayo Canyon site, Los Alamos, New Mexico, is a 1.5-acre site adjacent to the Township of Los Alamos on the west, and is about 62 miles north-northeast of Albuquerque and 25 miles northwest of Santa Fe. Remedial action of the radiological contamination was completed in FY 1982.

\section{Chupadera Mesa}

The Chupadera Mesa is part of the fallout area from the first atomic bomb test conducted for the Manhattan Engineer District on July 16, 1945 at the White Sands Proving Grounds in New Mexico. Based on a radiological survey report published in 1984, radiological remedial action is not required.

\section{Ashland 1}

Ashland No. 1, a 10.8-acre site which is currently part of the Ashland Oil Company refinery in Tonawanda, New York, was used to store waste residues from the Linde Air Products plant.

\section{Ashland 2}

Ashland No. 2, also part of the Ashland Oil Company refinery property in Tonawanda, New York, became contaminated when Ashland transported waste from the Ashland 1 property to a landfill area on Ashland 2.

\section{Baker and Williams Warehouses}

The Baker and Williams site consists of three adjacent warehouse buildings located on the west side of central New York (Manhattan), New York. During the early 1940s, these warehouses were used by the MED/AEC for short-term storage of uranium concentrates. Remedial action of all FUSRAP-related radiological contamination was completed in FY 1993. 


\section{Colonie}

The Colonie site, occupying approximately 11.2 acres in Albany, New York, includes the property formerly owned by National Lead (NL) Industries, including the Colonie Interim Storage Site (CISS), and all vicinity properties that became contaminated as a result of NL operations. The site was used by NL to manufacture a variety of products from depleted uranium.

\section{Linde Air Products}

The Linde site, located in Tonawanda, New York, was used by the AEC for uranium ore processing. This facility is owned by the Linde Air Products Division of the Union Carbide Corporation.

\section{NFSS Vicinity Properties}

The Niagra Falls Storage Site Vicinity Properties are located in Lewiston, New York. Remedial action of radiological contamination is complete.

\section{Niagara Falls Storage Site}

The Niagara Falls Storage Site (NFSS), Lewiston, New York, occupying approximately 191 acres, is used for the storage of low-level radioactive residues and by-products. Remedial action at NFSS was initiated in 1984, and remedial action of all radiological contamination on-site was completed in 1991.

\section{Seaway}

Seaway Industrial Park, Tonawanda, New York, covering nearly 100 -acres and bounded by the Ashland 1 and 2 properties, is currently operated as a landfill by Browning-Ferris Industries (BFI).

\section{Albany Research Center}

The Albany Research Center, U.S. Bureau of Mines, Albany, Oregon, was used for research on alloys of uranium and thorium, including the melting, machining, welding, and alloying of thorium. Remedial action at the site was initiated in FY 1987 and completed in FY 1991.

\section{Aliquippa Forge}

Aliquippa Forge, a 7.5-acre site located about 0.2 miles west of the Ohio River in Aliquippa, Pennsylvania, was used in the late 1940s for a uranium-rolling operation.

\section{Elza Gate}

The Elza Gate site, Oak Ridge, Tennessee, was used by the MED as a warehouse site for the storage of pitchblende and processed residues to support work at the "Clinton Laboratory". Remedial action of radiological contamination at the site was completed in early 1992.

\section{B\&L Steel}

The Bliss and Laughlin facility located at 110 Hopkins Street, Buffalo, New York, consists of a single large building, with a floor area of about 128,800 square feet. In the fall of 1952, the company performed machining and straightening operations on uranium rods which were shipped from Lake Ontario Ordinance Works. 


\section{Granite City Steel}

The Granite City Steel site is located at 1417 State Street in southwest Granite City, Illinois. The site occupant prior to the Granite City Steel division, General Steel Castings Corporation, x-rayed uranium ingots for the AEC.

\section{Madison}

The Madison site is in Madison, Illinois, northeast of St. Louis, Missouri. The site consists of a large, multisectional complex of ten interconnecting buildings with a total area under roof of approximately 1.4 million square feet. The site performed uranium extrusion and rod straightening work for the Mallinckrodt facility.

\section{Springdale}

The Springdale site is located at 644 Garfield Street in Springdale, Pennsylvania. C.H. Schnoor \& Company provided metal fabricating services and machined unbonded slugs from uranium metal rod in support of MED operations.

\section{Oxford}

The Oxford site is located at 10-14 West Rose Avenue, Oxford, Ohio. The site consists of approximately 7,000 to 8,000 square feet of former laboratory facilities. Work at the site included general machining and developmental machining of slugs for the Savannah River and Hanford reactors.

\section{Luckey}

The Luckey site, is located at 21200 Luckey Road, Luckey, Ohio. The site encompasses about 40 acres and includes structures such as production facilities, warehouses, transportation systems, and utility buildings. The site was used for the operation of magnesium reduction and beryllium production facilities.

\section{Painsville}

The Painsville site is located at 720 Fairport-Nursery Road in Painsville, Ohio and was used to operate a magnesium production facility. In July and August of 1952, Diamond Magnesium received approximately 750 tons of radioactively-contaminated scrap steel from the Lake Ontario Storage Area (LOSA) for use in controlling chlorine during the magnesium production process.

\section{B\&T Metals}

B\&T Metals is located at 425 West Town Street on the southwest side of Columbus, Ohio and consists of three buildings covering most of a city block. The site was used to extrude rods from uranium metal billets for the Hanford reactor. It is estimated that more than $\mathbf{5 0}$ tons of uranium were extruded.

\section{Baker Brothers}

The Baker Brothers site is located in Toledo, Ohio, at 2551-2555 Harleau Place. The site machined uranium rods that included most of the initial 100-ton requirement for Clinton slugs and a part of an additional 30-ton requirement for slugs. 


\section{Chapman Valve}

The Chapman Valve site is located in Indian Orchard, a suburb of Springfield, Massachusetts. The site conducted uranium operations for the AEC that were terminated on November 8, 1948. After the contract was completed, Chapman Valve had in their possession over 27,000 pounds of cortaminated metal scrap, oxides, and sweepings.

\section{Eairfield Site}

The former Pssociate Aircraft facility at 3660 Dixie Highway, Fairfield, Ohio, is still an operating machine shop with a total area of approximately 20,000 to 25,000 square feet. In 1956, the AEC and National Lead of Ohio contracted with Associate Aircraft to machine hollow uranium slugs for the Hanford and Savannah River reactors. Approximately 95,000 slugs were machined during the eight month contract period. 


\section{FORMERLY UTILIZED SITES REMEDIAL ACTION PROGRAM}

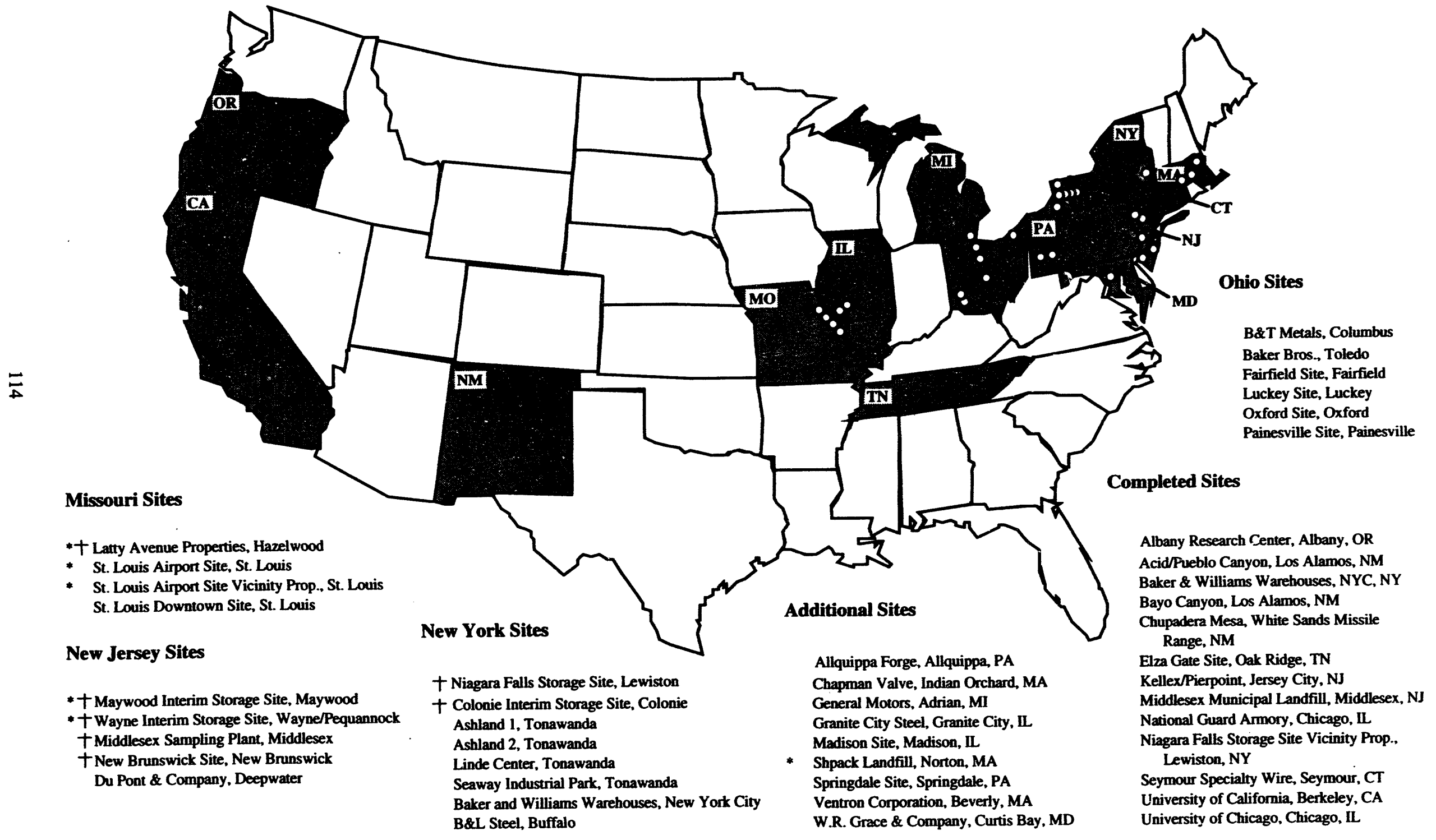




\section{OAK RIDGE K-25 SITE}

\section{ENVIRONMENTAL RESTORATION AND WASTE MANAGEMENT FACILITIES}

\section{DESCRIPTION}

The Oak Ridge K-25 Site occupies a 1500-acre area adjacent to the Clinch River, approximately 13 miles west of the city of Oak Ridge, Tennessee. The K-25 Site originally produced enriched uranium hexafluoride for defense purposes. A declining demand for enriched uranium caused the enrichment process at the K-25 Site to be shut down in 1987. The K-25 Site now serves as the location for many M\&O contractor central staff functions, EM organizations, and operating waste treatment and storage facilities. Most notably, the K-25 Site hosts the Toxic Substances Control Act (TSCA) Incinerator, a facility for the destruction of mixed wastes. A significant component of the current site mission consists of conducting investigations for identification and remediation of environmental contamination stemming from prior operations. The Oak Ridge Reservation (ORR), which includes K-25, was placed on the National Priorities List (NPL) in 1989. The site has been divided into 15 waste area groupings which will be addressed in accordance with requirements of the January 1992 CERCLA Federal Facilities Agreement signed by the State of Tennessee, DOE, and EPA. Existing facilities which are no longer in use are being systematically maintained or scheduled for decontamination and decommissioning.

\section{AGREEMENTS}

\section{Statute/Type}

Agreement in Principle

RCRA Land Disposal

Restrictions/Federal

Facility Compliance

Agreement (FFCA)

Clean Air Act, NESHAPS/Compliance Agreement

CERCLA/Federal

Facility Agreement

Toxic Substances Control Act/FFCA
Facilities

ORNL,K-25,Y-12

ORNL,K-25,Y-12

DOE/EPA

ORNL,K-25,Y-12 DOE/EPA

ORNL, K-25, Y-12 DOE/EPATN

ORNL, K-25, Y-12 DOE/EPA
Completed 6/12/92

Completed 4/14/82

\section{Status}

Completed 5/13/91

Completed 1/1/92

Completed 2/20/92 


\section{FACILITIES AND PROJECTS}

\section{Oak Ridge K-25 Waste Management Facilities}

\section{T-1: K-1232 Chemical Recovery Facility}

The K-1232 facility is used for neutralization of acids and bases.

\section{T-2: K-1407 Central Neutralization Facility (CNE)}

The Central Neutralization Facility treats all wastewater, including radioactively contaminated water, for $\mathrm{pH}$, heavy metals, and suspended solids in order to meet National Pollutant Discharge Elimination System (NPDES) discharge limits. Mechanical removal cleaning methods, among others, are used in combination with various cleaning solutions like water, steam, weak nitric acid, and sodium carbonate.

\section{K-1419: Sludge Fixation Facility}

The Sludge Fixation Facility is a modified concrete plant to fix mixed-waste sludge in a grout and concrete matrix, and is currently in a standby status.

\section{S-1: K-25 Building; Withdrawal Alleys and Vaults}

Basement vaults in Building K-25 are currently used to store LLW, RCRA mixed wastes, and PCB mixed wastes. Approximately 30 of these vaults are now in use.

\section{S-2: K-33 Process Building}

The permitted areas of operating and cell floors in Building K-33 are being used to store RCRA and TSCA mixed solid wastes and mixed waste sludges from the K-1417 Storage Yard.

\section{S-3: K-711 Hazardous Waste Storage Facility}

The Weld Training Facility in Building $\mathrm{K}-711$ is planned as storage for drums of flammable RCRA mixed waste awaiting incineration in the TSCA incinerator.

\section{S-4: K-726 Storage Building (TSCA)}

The K-726 Storage Building is being used to store drums of PCB mixed waste awaiting incineration in the TSCA incinerator.

\section{S-5: K-770 Contaminated Scrap Metal Storage Yard}

The Contaminated Scrap Metal Storage Yard is storing approximately 21,000 tons of contaminated scrap metal that is intended for eventual processing and/or decontamination for reuse.

\section{S-6: K-1025-C Hazardous Waste Storage Facility}

An 800 square foot building having six different dike systems to handle small quantities of various types of wastes. 


\section{S-7: K-1036-A Hazardous Waste Storage Facility}

A diked and covered hazardous waste storage facility with a capacity of about 600 drums.

\section{S-8: K-1202 Tank Storage Facility}

Two tanks, each having a capacity of 15,000 gallons store RCRA ignitable mixed waste that is destined for incineration by the TSCA incinerator.

\section{S-9: K-1302 Compressed Gas Cylinder Storage}

One room in this building is used to store defective compressed gas cylinders of all sizes.

\section{S-12: K-1420A Hazardous Waste Storage Tank}

The K-1420 Decontamination Facility contains tank storage (K-1420A, capacity of 30,000 gallons) for ignitable RCRA mixed waste destined for incineration in the TSCA incinerator.

\section{ORR Class I and II Disposal Facilities (future facility)}

New Class I and II solid LLW facilities are being developed on the ORR. Candidate sites for a new Class I facility include East Chestnut Ridge and West Chestnut Ridge. The facility will consist of a series of belowgrade, lined trenches with associated pumps and leachate collection systems. Each of the trenches will be designed to handle approximately $1.6 \times 10^{6}$ cubic feet of Class I waste. Sediment basins will catch and hold uncontaminated wastewater draining from the trenches. Leachate collected from the liner systems will be transferred to an on-site leachate treatment facility at $\mathrm{X}-10$ for processing before release to surface waters.

Candidate sites for a new Class II disposal facility include West Bear Creek Valley and SWSA 7. The facility will consist of groups of tumulus pads, abutted in echelon. The tumulus pads and their performance monitoring systems will be designed and constructed to be nearly identical to those for the Class II Integrated Waste Management Facility (IWMF ) proposed for ORNL. The Class II IWMF, while creating disposal capacity for ORNL during 1992-96, will serve as a prototype for the K-25 Class II disposal facility.

\section{ES-1: Oak Ridge Reservation Storage Facility (ORRSE) (future facility)}

The proposed ORRSF is designed to provide storage for large volumes of LLW, RCRA wastes, mixed wastes (both radioactive and RCRA hazardous), and TSCA wastes that are generated from waste management operations and corrective activities on the ORR, until on- or off-site treatment and disposal facilities are available. This project is being re-evaluated to reflect the updated storage strategy for the Oak Ridge Reservation.

\section{ES-2: Building K-27 Withdrawal Alleys and Vaults (WDAV) (future facility)}

Basement vaults in Building K-27 are to be used to store LLW, RCRA mixed wastes, and PCB mixed wastes.

\section{ES-3: K-31 Operating and Cell Floor (future facility)}

Building K-31's operating and cell floors are being used to store RCRA and mixed solid wastes in those areas permitted as waste piles, and TSCA wastes are being stored in diked areas. 


\section{FS-4: K-1065 A-E Pond Waste Storage Facility (future facility)}

These five buildings will be used to store the waste produced from the Pond Waste Management Project's dewatering and repackaging of 77,000 drums of waste from the K-1417 Drum Storage Yard.

\section{ES-5: K-1423 Waste Staging Facility (future facility)}

This building will be used for the initial storage of materials awaiting sample analysis for the segregation of waste into its appropriate class. This is primarily to separate radioactive contaminated material from other types.

\section{K-1024 FT-1 Filter Test Facility}

K-1024 belongs to the Site Program Organization Division; K-1024 FT-1 Filter Test Facility is located within K1024 and is still in the process of being transferred to the Waste Management Division.

\section{K-1071 Trash Compactor}

K-1071 Trash Compactor has been dismantled and remains out of service; this unit is located at K-770.

\section{K-1313-A Rubb Tent II Waste Storage}

K-1313-A Rubb Tent II is constructed of blue and white fabric membrane, measures 48 feet by 96 feet (4608 square feet), is located on the east side of $\mathrm{K}-25$ at $\mathrm{K}-310-1 /$ Vault $2 \mathrm{~A}$, and is used solely for the storage of lowlevel waste.

\section{K-1413 Treatment Tank}

Th's K-1413 facility was originally used as a tank storage and neutralization facility. It was also previously used as a back-up facility for the K-1232 WWTF. The Closure Plan (K/HS-332) has been submitted to the Tennessee Department of Environment and Conscivation for approval. Closure is expected to be completed during Fiscal Year 1993.

\section{K-1423 Y-12 Demonstration Project}

The K-1423 Y-12 Demonstration Project, conducted from late 1987 through mid-1988, involved a demonstration of a process for detoxifying mixed waste sludge. A closure plan, K/EM-4, for this project was issued May 1992. Closure certification will be submitted following approval of the closure plan.

\section{Site Operable Units}

The K-25 Groundwater Site Operable Unit (OU) includes all groundwater underlying the plant area even though discharge is to both Clinch River and Poplar Creek. The extent of groundwater contamination is not known at this time. Contaminants are primarily organics, including PC,Bs, but radioactive contaminants and some metals have also been found.

The K-1401 OU is located at Building K-1401 between 10th and 14th streets, west of Avenue D, and includes an acid line and degreasing operation. 
The K-1407 OU contains a neutralization pit, holding pond, retention basin, natural stream, two hazardous waste storage tanks, a burial ground, and soil excavated from a building project.

The K-1413 Treatment Tank OU includes a research and development building, a neutralization pit, two process drain pits, process drain lines from the pits to the K-1401 acid line, and storm drain lines that once received the facility's process discharges. Possible contaminants in the discharges include sodium and potassium hydroxides, uranium compounds, acids, and metals. Samples from the neutralization pit revealed traces of mercury.

The K-1420 OU consists of wastewater process lines, an oil-storage yard, an incinerator, and a mercury recovery room. During its histol $y$ of operations, the K-1420 facility has performed uranium, oil, and mercury recovery; cylinder cleaning; plating; decontamination of uranium enrichment process equipment; converter conditioning and recovery; feed-plant equipment cleaning and decontamination; and alumina leaching. Therefore, the K-1420 facility processes a wide spectrum of chemicals and uranium compounds, including transuranic (TRU) waste.

The K-1004 OU includes underground radioactive waste vaults, tanks, and two sets of recirculating cooling water (RCW) lines. The vaults and tanks, at one time or another, stored radioactive materials, including uranium, plutonium, neptunium, californium, technetium, and cesium. The one RCW system used a chromate/zinc/ phosphate corrosion inhibitor until 1977 when it was replaced by a phosphate treatment. The other RCW system used sanitary water treated with Dearborn 321 biocide, Dearborn 4622, and Zimmite Chemtrol 19. Both systems are now unused.

The K-1007 OU consists of an area laboratory drain, the holding pond to which it flows, and a gasoline tank. Wastes discharged into the K-1007 Area Lab Drain beginning in the 1940s are suspected to have included a wide variety of acids, organic compounds, metals, and radionuclides. The laboratory area facilities continue to operate. Beginning in the 1950s, the K-1007-P1 Holding Pond received wastes from the area lab drain, along with stormwater runoff.

The K-1064 OU is located northwest of Building K-25 on a peninsula formed by a bend in Poplar Creek, and includes two cooling tower basins and a drum storage and burn area. The cooling towers were built in the mid 1940 s and used a zinc/chromate/phosphate treatment system from the 1950 s to 1977 . Both towers were demolished in the late 1970s, but a portion of K-801-H was rebuilt and is in use. One basin is in use for firewater makeup. The Drum Storage and Burn Area was used to store and burn waste solvents in the 1950s. From 1960 to 1983, paint wastes, organic wastes, and radioactively contaminated waste oil, including PCBs, were stored at this location. Suspected chemicals used are primarily organics, radioisotopes, and metals.

The K-1410 OU includes a neutralization pit, waste paint accumulation area, and a building formerly used for uranium decontamination, process equipment recycling, and nickel plating.

The K-29 OU includes the K-27 and K-29 RCW system and switchyard, and a sewage treatment plant. The RCW lines employed a zinc/phosphate/chromate system which was used as a corrosion inhibitor.

PCB contaminated oil is the only suspected contaminant at the switchyard. Analytical data indicate that the concentrations of several metals detected in sampled sludge are above guideline values at the sewage treatment plant.

The K-33 OU includes four cooling tower basins, their RCW lines, and two switchyards. The cooling water systems used corrosion inhibitors including zinc, phosphate, and chromium. In addition, a biocide treatment used on the cooling towers likely produced a variety of zinc and copper salts. PCB-contaminated oils are the only suspected contaminants for the switchyards. 
The K-901 OU consists of a contaminated burial ground, landfarm, holding pond, two construction waste disposal areas, and underlying groundwater. The burial ground contains, among other things, uranium and thorium contaminated material. The landfarm received clay laden with concentrated acids, sludges, and other degradation products from uranium enrichment cascade oil. The holding pond received chromated, cooling-tower water blowdown and a variety of the wastes from barrels drained into the pond in the late 1950s. The waste disposal area and sanitary disposal areas received construction wastes, and small pockets of radioactive contamination have been found.

The K-770 OU consists of a contaminated scrap metal yard and contaminated debris, two buildings used as part of a thermal diffusion plant in the 1940s, and a sewage treatment plant. The scrap metal yard contains waste materials contaminated with uranium, TRUs, mercury, and asbestos. There is a building on the site which was used for storing PCBs. Suspected contaminants of concern are beryllium, mercury, asbestos, and uranium. In 1950, a transformer exploded at the switchyard, releasing PCB-contaminated oil onto the area. Sewage that may contain traces of radioactive contaminants is present at the sewage treatment plant.

The K-1070 OU includes a 22-acre burial ground and three storage dikes. Low-level radioactive and nonradioactive, nonhazardous waste materials and equipment were buried in large trenches. Wastes include hazardous chemicals and solvents, including a variety of organics. Heavy metals, including uranium and lead, were also buried at the site. The storage dikes contained various hazardous and mixed wastes during their use.

The K-25 OU consists of a dilution pit. Beginning in 1945, the pit received acid/solvent solutions from the building process drain lines that once served the instrument maintenance shops. For the $1970-1985$ period, the west wing of the building accommodated a centrifuge development laboratory operation. The contaminant of concern is uranium.

The K-1417 Drum Storage Yard OU is a RCRA-permitted waste storage area. There are 78,000 drums containing sludge from a holding pond and a retention basin. The sludge, which contains inorganic, organic, and radioactive contamination, was removed from the ponds during RCRA closure activities in 1988. The OU includes the K-1419 Sludge Treatment Facility which still contains 16,000 gallons of sludge in three tanks.

\section{Oak Ridge K-25 Site Decontamination and Decommissioning Facilities}

The K-25 Building is a steel-frame, three-floor, U-shaped building with cement/asbestos siding. It is 4,975 feet by 400 feet. It has 54 units with 2,800 stages of enrichment equipment. The abandoned process equipment contains residual uranium deposits and was used for $U^{235}$ isotope separation from 1945 until 1964.

K-27 is a steel-frame, three-floor building of 388,000 square feet with cement/asbestos siding and with dimensions of $960 \times 405 \times 58$ feet. It has nine units and 540 enrichment stages. The equipment, which was used to process $\mathrm{UF}_{6}$ for $\mathrm{U}^{235}$ isotope enrichment from 1945 until shutdown of the site in 1985, contains residual uranium and technetium deposits.

K-29 is a steel-frame, two-story building with insulated metal siding and dimensions of $560 \times 523 \times 72$ feet. It contains 300 stages of gaseous diffusion equipment, and which operated from 1949 to 1985.

K-31 is of steel-beam-on-slab construction with cement/asbestos siding. Its dimensions are $1,200 \times 622 \times 67$ feet with a 16.5-acre first floor area and 50 million cubic feet volume. It contains six units and 600 stages of gaseous diffusion equipment, which operated from 1951 to 1985 , and contains residual deposits of uranium oxide and oxyfluorides. 
K-33 is of steel-beam-on-slab construction with cement/asbestos siding. Its dimensions are $1,450 \times 970 \times 82$ feet with a 32-acre first floor and 115 million cubic feet volume. It contains eight units and 640 stages of gaseous diffusion enrichment equipment, which operated from 1954 to 1985, and contains residual deposits of uranium oxide and oxyfluorides.

The tielines for Buildings K-25/K-27, K-27/K-131, K-27/K-413, K-27/K-631, K-27/K-633, K-27/K-1131, K$31 / K-631$, and K-33/K-31 consist of multiple distribution pipes of 3 inch to 42 inch diameter and are enclosed in thermal insulated housing and vary in length from 50 to 2,000 feet. They are secured to either elevated pipe bridges or ground-level concrete piers and provided distribution of gaseous $\mathrm{UF}_{6}$ between the process buildings during operation. They were shut down in 1985 and contain residual deposits of uranium.

K-101 is a concrete block building erected in 1944. It has three floors and has a first floor area of 2,400 square feet. It initially housed $\mathrm{UF}_{6}$ feed purification equipment for the $\mathrm{K}-25$ process building. It was later used for distillation and recovery of fluorocarbon coolant and as a field maintenance shop.

$\mathrm{K}-131$ is of cinder block construction and has five floors with a first floor area of about 13,000 square feet. It was constructed in 1945 to house $\mathrm{UF}_{6}$ purification and vaporization equipment for the K-27 Building. The purification equipment was never used. The building has served as a uranium recovery facility and as a field maintenance and sludge treatment facility until shutdown in 1985.

$\mathrm{K}-413$ is a two-story clay tile structure with a ground floor area of 15,800 square feet and is 18 to 40 feet high. It was constructed in 1945 to house product-withdrawal equipment for K-27. It also functioned as a fluorine-cell maintenance shop and a fluorothene plastic production facility. It was shut down in 1985.

K-631 is two-story concrete block building with a full basement and is $315 \times 110 \times 55$ feet. It is connected by a tie line to K-27. It was constructed in 1945 to remove depleted $\mathrm{UF}_{6}$ from K27. The large volume tanks later provided surge volume for the K-1131 tails withdrawal facility and storage/feed facility for reactive gases until plant shutdown in 1987.

K-633 is a one-story steel-frame building with asbestos siding and a floor area of 18,000 square feet and 20 feet height. It was originally constructed in 1951 to provide facilities for testing $\mathrm{UF}_{6}$ gaseous diffusion enrichment process compressors, valves, and other equipment. It was shut down in 1986. The process equipment, which includes pipe loops exterior to the building, contains residues of isotonically depleted uranium.

The K-633-D test loop storage/control room facility is a trailer that provides data collection equipment for the K-633 process equipment test loop facility. It was used from the 1950s until 1986.

The K-1040 Test Loop Maintenance shop is a wood-frame building located adjacent to the K-633 Test Loop. It was built in the 1940 s as a fire house, modified to serve as a maintenance shop in 1951, and was shut down in 1986.

The K-701 boiler house is a $192 \times 147 \times 140$ foot steel frame structure with brick exterior built in 1944 . It originally housed three steam boilers for generation of variable frequency power for K-25. The boilers were removed in the 1960s. It was later used as a maintenance fabrication shop.

The K-702 turbine room is about $600 \times 100$ feet and is of steel frame construction with brick exterior. It was constructed in 1944 to house steam turbines and electrical generators for the K-25 Site. The turbines were removed in the mid 1960s, and the building was used by the Pressure Vessel Test Facility and the Pressure Thermal Shock Facility. 
The K-703 Power House Auxiliary Building is a three-story concrete/steel frame structure with brick exterior built in 1944. It provided the power house office and laboratories. An additional structure provided a coal conveyor for the boiler house. The laboratories were later used by the Molecular Anatomy Program of the Oak Ridge National Laboratory Biology Division. Maintenance and engineering used the offices in the 1980s.

The K-705-B Crib House is a wood-frame building of 900 square feet with cement/asbestos siding. It was constructed in 1944 and provided equipment below grade for channeling water from the Clinch River to the K-700 Power House. This equipment was shut down in 1962.

The K-706 Pump House is a wood-frame two-story building with cement/asbestos siding. It is $115 \times 28 \times 30$ feet and housed circulating cooling water pumps for the power house. It was constructed in 1944 and shut down in 1962. The below-grade substructure is flooded to a depth of ten feet.

The K707 Auxiliary Switch House was built in 1944 to distribute electrical power from the power house to K-25. It is a 6,540-square foot concrete block structure with brick walls. It has three floors and a basement and houses electrical switchgear that was abandoned in the 1960 s.

The nonoperational K-709 Electrical Switchyard was built in 1944 and contains surplus electrical equipment that was disconnected in 1962. The switchyard is about two acres in size and includes an oil filtering facility, a transformer oil storage tank, and a sprinkler valve house.

$\underline{\text { K-724 }}$ is a one story concrete masonry structure with a corrugated cement/asbestos roof. It was built in 1944 to support the thermal diffusion enrichment process operated by Fercleve and is now an abandoned warehouse. It has 8,000 square feet of floor space.

The K-735 Warehouse Building was a water treatment plant for the Fercleve Thermal Diffusion Plant. It was constructed in 1944. The basement level walls and ceiling are concrete; an upper level is framed with wood and covered with a corrugated metal roof and walls. The building was used for storage after shutdown in 1946.

The K-762 Switch Yard occupies about three acres. It was constructed in 1952 to receive TVA power and supply the K-3i process building. It contains $161 \mathrm{kV}$ transformers, condensers, and duct and switchgear and was shut down in 1985. K-762 Valve Vaults 1 and 2 are corrugated cement/asbestos structures of $15 \times 30$ feet. They house below-grade valves for the water-fire suppression for the electrical transformers and circuit breakers.

The K792 Electrical Switch Yard received TVA power and distributed it to the K-33 process building. It occupies 7.5 acres and contains $161 \mathrm{kV}$ transformers, circuit breakers, and high voltage cables and busses. It was built in 1954 and shut down in the 1980s. The K-792 Valve Houses No. 1, 2, 3, and 4 are $8 \times 16$ feet concrete block structures with below-grade valves for the water-fire suppression system for transformers and oil circuit breakers.

The K-832 facility is a recirculating water pump house constructed of reinforced concrete frame and clay tile interior partitions $30 \times 20$ feet. It houses seven pumps with 700-hp motors for recirculating cooling water to the K-832 tower. Two chemical storage tanks are located outside the building. The K-832 $-\mathrm{H}$ Cooling Tower was constructed in 1985 and shut down in 1987. It is $150 \times 36 \times 28$ feet and is fabricated of fir, redwood, PVC, and fiberglass. It provided cooling for the K-27 and K-29 process building recirculating water systems.

The K-862 Recirculating Water Pump House has a floor area of 6,800 square feet and is a frame building with cement/asbestos siding. Seven recirculating water pumps and one firewater pump are provided with auxiliaries such as control instruments and water treatment chemical tanks. It was built in 1951 to recirculate cooling water between the K-31 process building and the K-861 cooling towers. The K-861 Cooling Tower consists of 16 cells 
and is $385 \times 63 \times 38$ feet. It was constructed of redwood and fir in 1951 to cool the recirculating cooling water (RCW) for the K-31 process building. It was shut down in 1985. The K-861-J Cooling Tower, which provided cooling for K-31 process building RCW, was constructed of redwood and asbestos materials in 1978 and was shut down in 1985. It is $42 \times 30 \times 26$ feet.

The K-892 Recirculating Water Pump House consists of three sections. One section is a concrete frame with concrete masonry which houses water-treatment chemical tanks and feed equipment. The second section contains eleven 20,000-50,000 gpm recirculating water pumps, water piping, and valves. The third section houses electrical transformers, diesel fuel, and chemical storage tanks. The floor area is 23,000 square feet. K-892 was constructed in 1954 and shut down in 1989.

K-892-G and K-892-H counter-flow evaporative cooling towers each contain 11 cells and are supported above a 26-foot deep reservoir. The towers are $349 \times 63 \times 38$ feet. They were constructed of redwood in 1954 and were shut down in 1985.

They K-892-J tower was constructed of redwood and asbestos in 1978 and shut down in 1985 . Its dimensions are $462 \times 30 \times 26$ feet.

K-896, constructed in 1976, is a 450 square feet steel-frame building with corrugated steel siding. It houses chemical feed equipment, including pumps, motors, and so forth. It was used for treatment of toxic chromate in the recirculating cooling water system.

The K-896-A and K-896-B 40 foot diameter steel tanks were provided to support the chromate treatment facility and were installed in 1974 and 1980, respectively.

The K-1004-L UF Pilot Plant occupies 42,000 square feet and is of concrete block construction. Gaseous diffusion process barrier evaluation equipment, laboratories, and offices are housed in this building, which was constructed in 1957.

The K-1004-N cooling tower is $20 \times 20 \times 15$ feet. It is constructed of wood with asbestos siding to cool the $\mathrm{RCW}$ from the pilot plant.

$\mathrm{K}-1024$ is a one-story, wood-framed building with cement/asbestos shingle siding of 4,800 square feet. It was built in 1944 as an instrument maintenance shop to support the K-25 Building. It currently houses D\&D offices and a HEPA filter test facility.

The K-1024-B facility is a $30 \times 45 \times 10$ foot concrete block structure that was constructed in 1955 and now houses security department offices.

$\mathrm{K}-1024-\mathrm{C}$ is a $15 \times 30 \times 8$ foot wood frame building with cement/asbestos siding. It was constructed in 1955 and is now used as storage for D\&D Division operational supplies.

$\mathrm{K}-1024-\mathrm{D}$ is a $12 \times 40$ foot mobile office building. It is now used as a field office for Health Physics personnel.

K-1031 as constructed in 1945 as a maintenance support facility for K-27. It is a $76 \times 35 \times 16$-foot wood-frame, one-story building with cement/asbestos siding which has been used as a storage facility by the power/utilities department for emergency plumbing equipment. 
K-1037 Industrial Research Facility is a multi-use facility constructed in 1945 with expanded additions in 1950 and 1970. The original structure was a warehouse and later housed the barrier production facilities for all gaseous diffusion plants. It is a single-story, $820 \times 400$-foot building with a partial basement. Approximately 40 percent of the building is used by the AVLIS program and office area. The remainder of the facility houses barrier production equipment that was abandoned in 1987. K-1037-C Smelter House is a $50 \times 80 \times 20$ foot steel-frame building with concrete block siding. It housed a nickel smelter for processing barrier material. It was constructed in 1954 and shut down in 1987.

The K-1066-B UF 6 Cylinder Storage Yard has a concrete surface of 50,000 square feet and provides storage for 420 cylinders with 30 and 48 inch diameters.

The K-1066-E UF Cylinder Storage Yard has 167, 637 square feet of concrete and gravel surface. It was built in 1947 and expanded in 1970. Long-term storage of 1,717 10- and 14-ton cylinders of UF ${ }_{6}$ is now provided in this yard.

The K-1066-I Cylinder Storage Yard has a gravel surface of 62,600 square feet and provides storage for 2,300 cylinders. Approximately half of these cylinders are empty; the others contain $\mathrm{UF}_{6}$ of normal assay. The yard has been used since 1951 .

The K-1066-K Storage Yard has a concrete surface of 80,652 square feet and contains 2,949 cylinders of depleted $\mathrm{UF}_{6}$ tails. It was built in 1981 .

The K-1131 Building was constructed in 1945 as an air plant for the K-27 process building. In the 1950s it was converted to a UF 6 production facility, which was shut down in 1964. The K-25 tails withdrawal and UF feed vaporization operations were performed in this building from 1965 to 1985 . A fluorine production facility was housed in this building from 1952 to 1982 . K-1131 is a one-story steel-frame building with cement/asbestos siding ( $390 \times 110 \times 45$ feet).

The Three K-1132 sheds provide shelter for four anhydrous hydrogen fluoride storage tanks of 12,500-gallon capacity. Tank car unloading and hydrogen fluoride distribution and neutralization systems were also provided.

The K-1135 facility is a $15 \times 20$ foot, one-story building of concrete block construction. It was built in 1951 to house instrumentation to control hydrogen fluoride storage tank operations.

The K-1231 Building was constructed in 1945 to provide maintenance support for the $\mathrm{K}-27$ process building. It is a one-story, steel-frame structure with cement/asbestos siding (162 × $42 \times 40$ feet). It later housed uranium oxide pulverizing/screening equipment and chemical processing equipment, and was shut down in 1982.

$\mathrm{K}-1231-\mathrm{A}$ is an abandoned propane storage facility that has eight horizontally mounted 1,000-gallon steel tanks that are about $3 \times 20$ feet. These tanks were in service from 1955 until 1985.

$\mathrm{K}-1231-\mathrm{B}$ is an abandoned 5,000-gallon steel chemical storage tank that is six feet in diameter and 25 feet in length. It was installed in 1965 and shut down in 1985.

K-1233 is a two-story, steel-frame, metal-sided building with $100 \times 50 \times 20$-foot dimensions. It housed chemical processing equipment such as tanks, pumps, and piping, which were in use from 1976 until 1988.

$\mathrm{K}-1233-\mathrm{A}$ is a one-story, steel-frame building with steel-panel siding ( $30 \times 30$ feet). The building housed equipment for cleaning 55-gallon drums which operated from 1955 until 1985. 


\section{K-25 SITE}

The K-1251 barge unloading facility, established in 1953, has a 25-foot pier and a 27-ton boom and crane for unloading barges on the Clinch River. The facility includes a $12 \times 20 \times 9$ foot crane control house. The facility is inactive and electrically de-energized.

The K-1300 facility is an 85 foot high brick disposal stack. It was built in 1944 and shut down in 1985. Fans, exhaust housing, and underground ducts are provided which diluted and discharged fluoride emissions from buildings in the vicinity.

The K-1301 Fluorine Production Facility was constructed in 1944 of clay tile. It is a two-story building of 7,625 square feet. An air-liquefaction facility with liquid nitrogen distribution equipment was also located in this building in the 1960s. Office and personnel change houses are also provided.

The K-1302 Gaseous Fluorine Storage Facility was constructed of ten-foot concrete walls and a corrugated metal upper section. It was built in 1944 to house five nickel-clad fluorine storage tanks. It is a one-story building of 3,200 square feet. Gas distribution headers and underground ducting to the exhaust stack are provided.

K-1303 is a one-story brick/concrete structure built in 1944 to house equipment for fluorine liquefaction and vaporization in 1945. From 1947 to 1954, the building housed equipment to decontaminate diffusion process equipment and recover uranium. It later was converted to an air test facility. The building is 16,000 square feet.

The K-1401-N unit is a portion of the large 400,000 square foot maintenance shop facility that was built in 1944 . The northwest portion of the building has a $340 \times 200 \times 17$ foot basement. Abandoned converter conditioning equipment is located in this area.

The K-1410 Building was constructed in 1945 as a maintenance facility for the K-25 process building. It is a steel-frame structure with cement/asbestos siding with an 8,360 square foot area. From 1948 to 1970 it housed uranium processing and equipment decontamination facilities. Electro-nickel plating equipment was operated in the building from 1972 to 1985.

The K-1413 Engineering Laboratory is a two-story, steel-frame brick and concrete structure with 8,500 square feet of floor area. It and the attached metal building additions house chemical processing equipment used for fluoride and uranium research and development processes. It was built in 1952.

K-300-C contains 2 two-story wood frame buildings with transite siding and roof. One of the buildings is badly deteriorated and near collapse. With the exception of one coolant storage tank, all process pipe pumps and equipment have been removed. The remaining tank is open. One of the storage buildings is currently being used as a radioactive materials storage area (RMSA).

K-712 is a brick building with a concrete roof. The building was built on a concrete foundation five feet above grade. K-712 was originally an electrical substation and distribution for the Fercleve Thermal Diffusion process. There are 480 volt breakers present that supply power to K-722, K-723, and K-724.

K-734 is a two story building with first floor concrete walls and second floor transite siding. It is approximately 178 feet by 38 feet. K-734 was originally a pumphouse to support the Fercleve Thermal Diffusion process. The first level of K-734 has an open truck entrance on the north end and contains mortar and sand.

K-738 is a one story concrete building with transite roof. It has an attached, sheltered storage area of equal dimensions. K-738 was originally constructed as a chlorinator house to support the powerhouse operations. $\mathrm{K}-738$ is currently being used for compressed gas cylinder storage. The compressed gas cylinders are to be removed. All process equipment has been removed. 
K-766 is a one story wood frame structure. K-766 is formerly the powerhouse slag disposal area. The building is enclosed by a fence. The fenced area contains several B- 25 storage containers.

K-801 is a one story building with transite siding and roof. K-801 is an obsolete raw water pumping and treatment facility. The raw water intake pipes and pump are located below grade in the K-801 pumphouse. This equipment has not been operated for more than thirty years.

K-801-A is a two story concrete building. K-801-A water treatment building contains empty chemical water treatment piping and tanks on the second floor. K-801-A has a cathodic protection system for underground piping present. The K-801-B Clarifier Tank was used as part of the K-801 water treatment facility. The K-801-B is accessed by a cat-walk from the second floor of K-801-A.

$\mathbf{K - 8 3 3}$ is a one story wood frame building with transite siding and roof. It does not contain an active fire suppression system. K-833 contains a large, submersed water pump. K-833 was used as the cooling water return pumphouse for the K-27 Switchyard.

K-834 is a concrete vault with a wood building superstructure. The single story building has a transite roof. The original wood frame has asbestos/cement siding and the wood floor is deteriorated. The K-834 Building was used as a valvehouse for recirculating cooling water ( $\mathrm{RCW}$ ) from the $\mathrm{K}-832$ Pumphouse.

K-891 is a one story building with concrete masonry unit walls and a concrete roof. K-891 contains six intake water pumps, motors, and electrical switchgear. This facility was used to pump water from Poplar Creek to the K-892 Water Treatment Facility for treatment to be used as make-up in the recirculating cooling water systems.

K-1025-E is a one story building with a concrete block foundation and transite siding. K-1025-E is now empty but has been used in the past for storage of material including uranium.

K-1401-NB is the basement area of Building 1401. Part of the space is being used for offices, labs, and storage. The furnace stands located in the basement no longer have a mission.

K-1420 floors are concrete and the walls are concrete up to the 8 foot level. Above the 8 foot level is corrugated asbestos siding. K-1420 provided radiological decontamination of the K-25 Site process equipment with subsequent uranium recovery. It was also used for nickel plating operations.

K-1421 is a concrete block building structure. It has an attached, sheltered storage pad that is twice the size of the building. The storage pad has corrugated asbestos siding. K-1421 contains an incinerator with afterburner.

$\mathrm{K}-1422$ is partially enclosed with transite siding. $\mathrm{K}-1422$ is a former sheltered concrete fissile material storage area.

K-1501-E is a cinder block building with metal siding. K-1501 is made up of a coal crusher, vibrating screens, and a conveyor system constructed in the 1980s to process mine run coal and provide stroker grade coal for the $\mathrm{K}$ 1501 Steam Plant. This facility was operational until the K-1501 Steam Plant was converted to gas fuel in 1990.

\section{Oak Ridge K-25 Site Decontamination \& Decommissioning Centrifuge Facilities}

K.797 is a concrete-block, electrical-switch gear room which houses electrical distribution equipment for $\mathrm{K}-1004-\mathrm{J}$. It was erected in 1968 and has 2,750 square feet of floor area.

K-798 is a $65 \times 30 \times 13$ foot prefabricated metal building that houses a $13.8 \mathrm{kV}$ transformer and electrical switchgear for the centrifuge facility. It was built in 1975 . 
K-1004-J is a single-story, concrete block structure with 7,250 square feet of floor area. It was built in 1950 and housed laboratory chemical processing equipment for Hanford reactor fuel recovery development activity. The building was later used for centrifuge enrichment development activity.

The K-1004-Q addition to the Centrifuge Equipment Test facility was completed in 1971. It has 1,760 square feet of floor space and is of steel-frame/concrete-block construction. It was provided for testing and assembly of gas centrifuge components and has a $25 \times 25 \times 14$-foot-deep pit.

K-1010 is a one-story, stecl-frame structure with corrugated metal siding. It was built in 1972 . It has 20,000 square feet of floor area and was a gas centrifuge research facility that supported the equipment test facility activity in the K-1023 Building. Offices and a polymer laboratory are also provided in this building.

K-1023 is a prefabricated structure of 110,000 square feet which was constructed in 1971 . It is 50 feet high with an 85 -foot-high bay. The building housed gas centrifuge reliability testing equipment to support the equipment test facility. It was later renovated to provide laboratory and development equipment for the centrifuge program.

K-1045 is a one-story, concrete-block building ( $36 \times 20 \times 19$ feet). It was built in 1945 and was converted in 1982 to a centrifuge valve certification laboratory. It was later used as a storage facility for Enichment Business Services magnetic media.

The K-1052 and K-1052-B building is a $200 \times 100$-foot steel frame structure with metal siding and a high hay area. It was built in 1974 to develop, test, and demonstrate advanced gas centrifuge technology. Laboratory and office space and change houses are provided.

The K-1004-N-1 Recirculating Water Cooling Tower was built in 1972 to provide for the centrifuge plant's cooling requirements. The tower is constructed of redwood with a concrete basin. A fire-water valve house is provided in a small metal enclosure.

The $\mathbf{K}-1200$ building is a steel-frame, concrete-block structure with metal siding. It was built in 1974 and was used for centrifuge preparation and testing until 1985. Isotope research work was continued in the building until 1990. the building has a floor area of 68,400 square feet and consists of three bays that are $60 \times 400 \times 20$ feet, $60 \times 400 \times 30$ feet, and $60 \times 400 \times 80$ feet, respectively. The total area of K-1200 is over three million cubic feet.

$\mathrm{K}-1004-\mathrm{N}-2$ is a small cooling tower with recirculating pumps and water distribution piping. It was constructed in 1972 to provide cooling water to Advanced Machine Development Laboratory facility.

The K-1210 Centrifuge Test Facility structure was built in 1975. An operations control room has been converted to an office complex. Decommissioned gas centrifuge machines are installed in the operating area. The centrifuge test facility building is a high bay structure with over 25,000 square feet of floor area. It is a steel-frame structure with metal siding.

The K-1210-A structure was built in 1977 as an addition to the K-1210 Building and has approximately one-third of the floor area of K-1210. It supported the advanced Equipment Test Facility in the K-1210 Building.

K-1220 Centrifuge Plant Demonstration Facilities 1 and 2 were provided in 1982 to demonstrate the productivity and operability of equipment designed for the Portsmouth Gas Centrifuge Enrichment Plant. They contained an area of 75,000 square feet and were shut down in 1985. They were attached to the K-1210 Building by an equipment-transfer corridor. A cascade central room, cranes, and monorail were provided for centrifuge machine transport. Portions of these buildings are being used as a Physics and Laser Laboratory, a maintenance shop, and an office complex. 
The K-1600 Technology/Seismic Test Facility building is a steel-frame structure with corrugated metal siding. They has a 100 foot high hay and a 30 foot-deep pit. It was built in 1973 to support the gas centrifuge enrichment program and has a 30,000 square foot first floor. 
OAK RIDGE RESERVATION

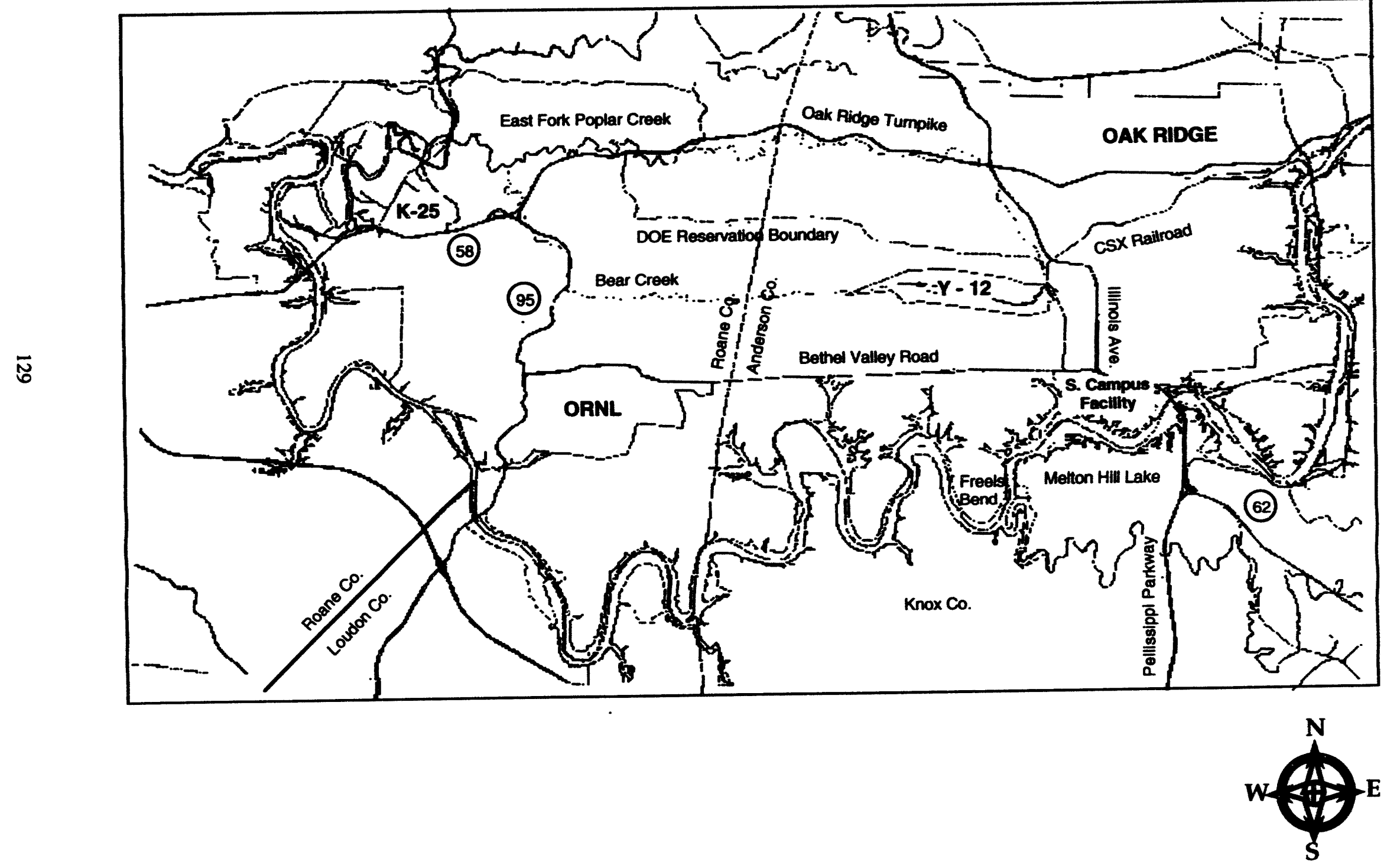




\section{K-25 SITE WASTE MANAGEMENT FACILITIES}

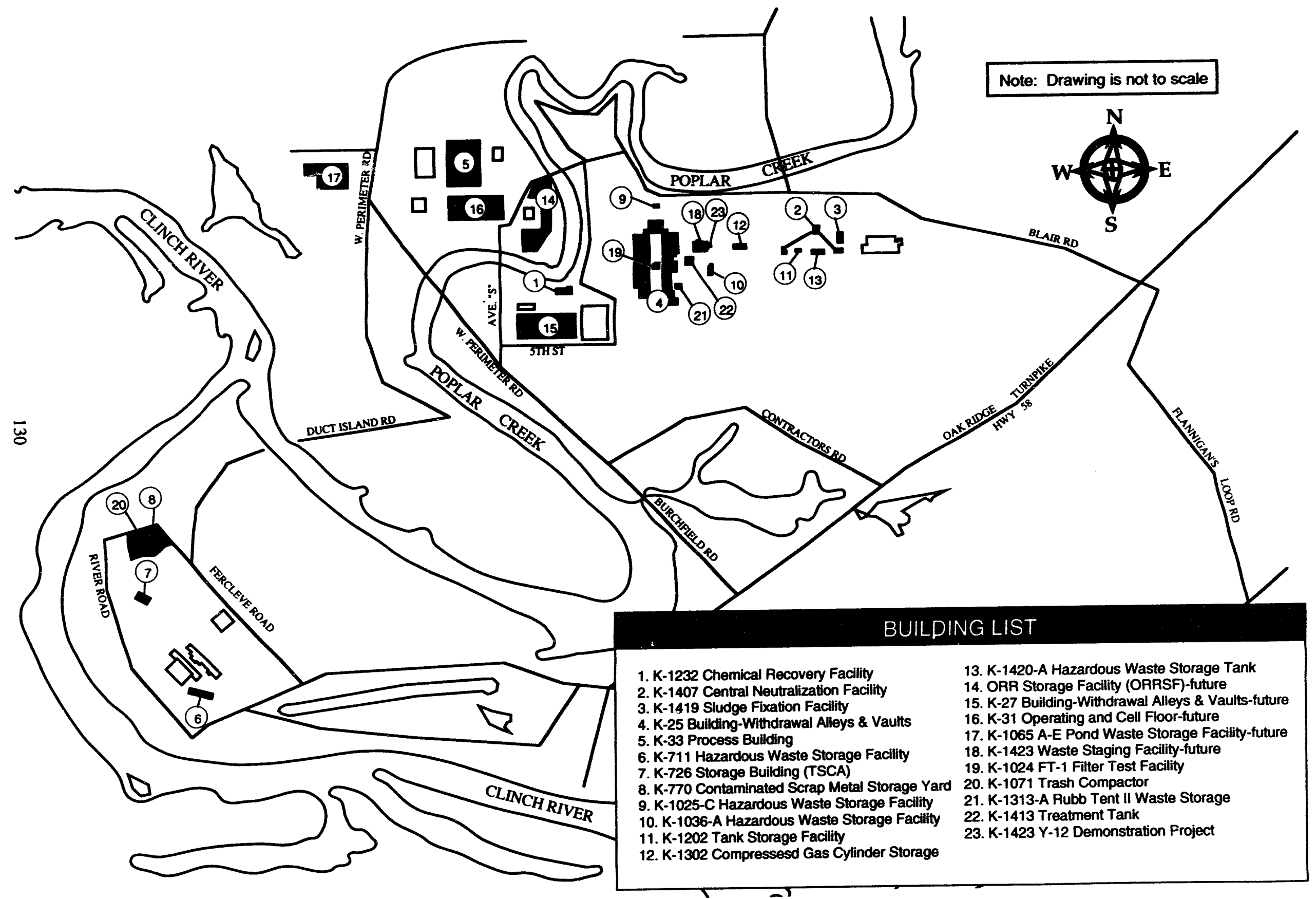




\section{K-25 SITE OPERABLE UNITS}

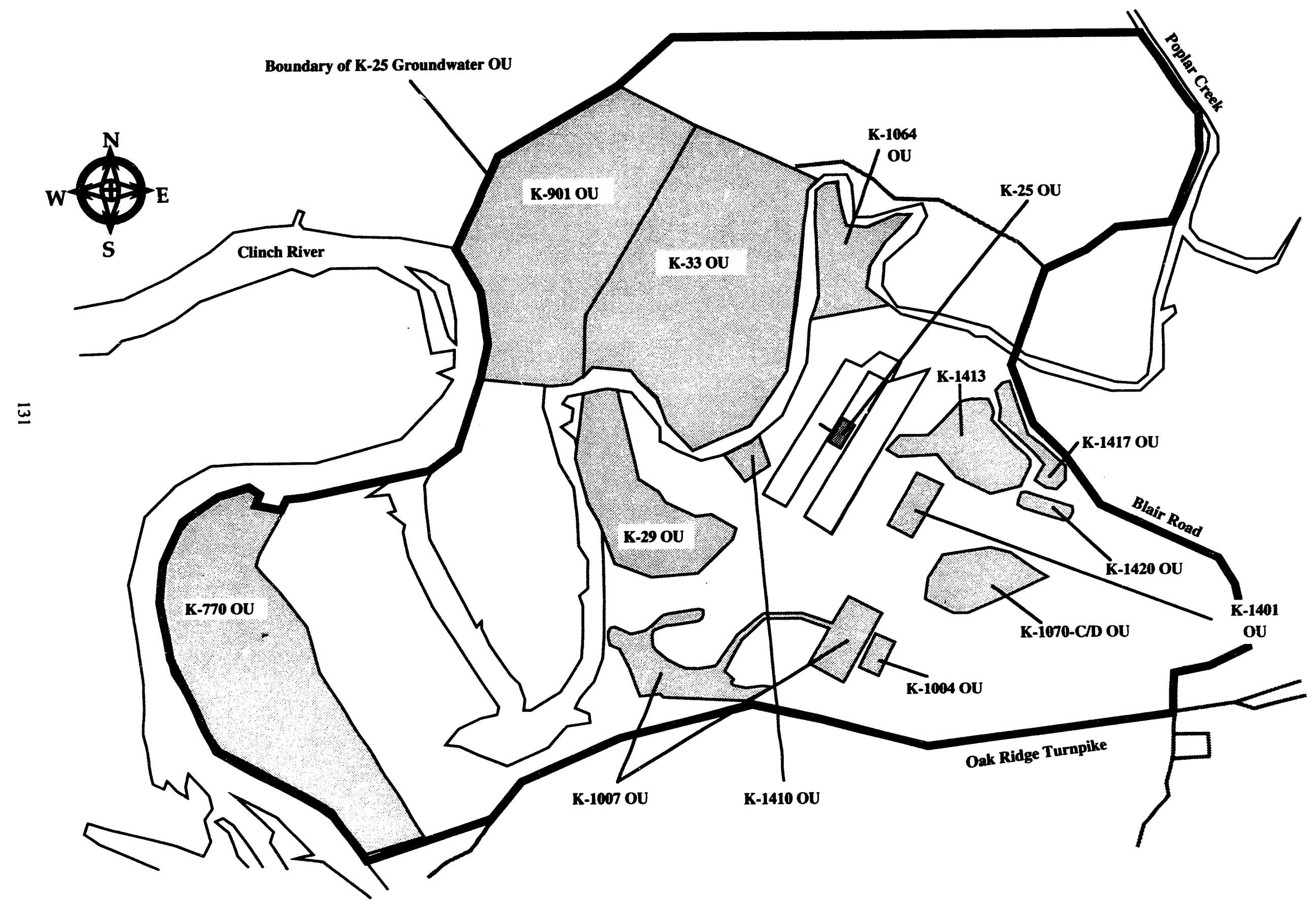




\section{K-25 DECONTAMINATION AND DECOMMISSIONING FACILITIES}

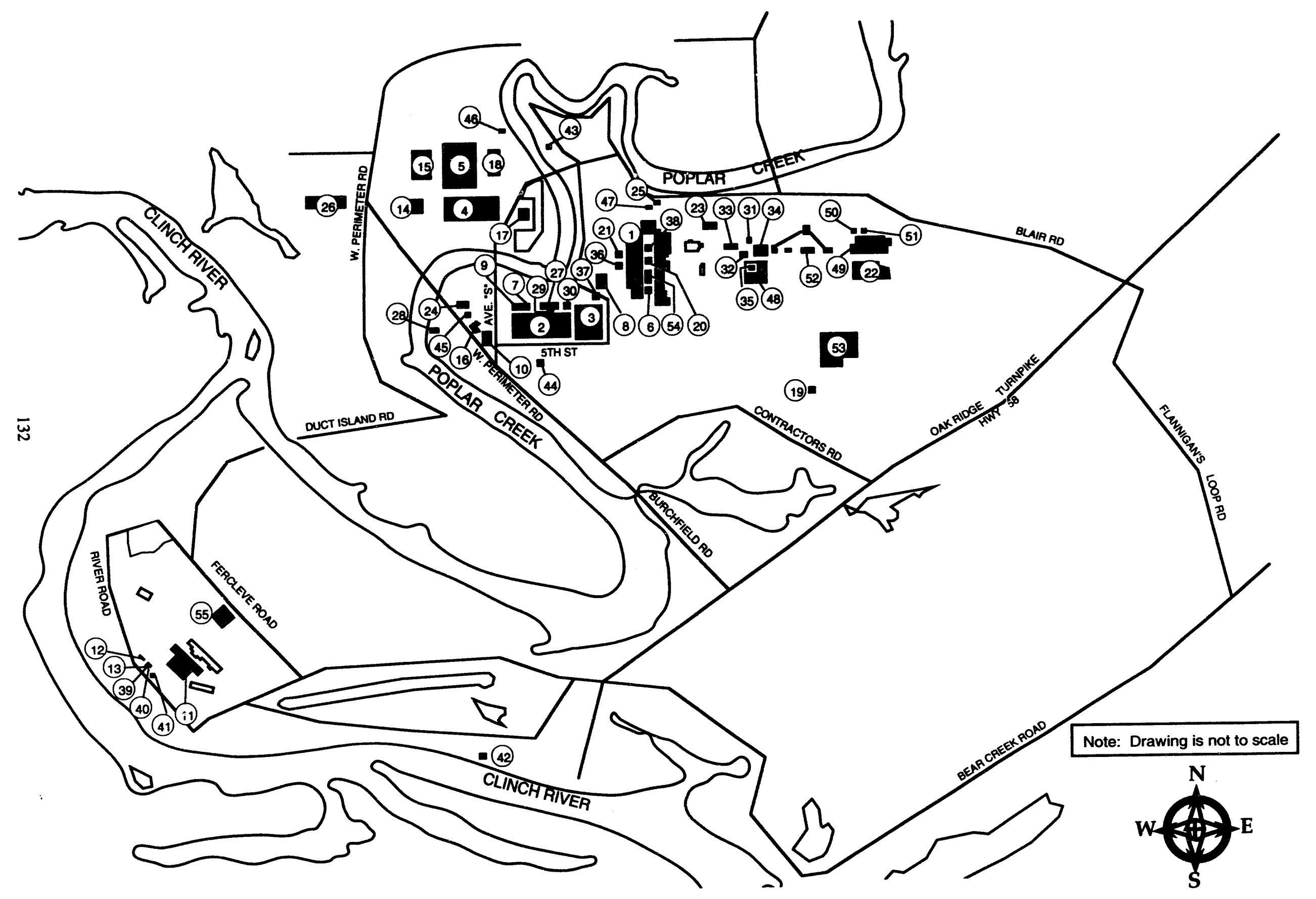




\section{K-25 SITE DECONTAMINATION AND DECOMMISSIONING FACILITIES}

\section{BUILDING LIST}

\author{
1. K-25 Building \\ 2. K-27 Building \\ 3. K-29 Building \\ 4. K-31 Building \\ 5. K-33 Building \\ 6. K-101 Building \\ 7. K-131 Building \\ 8. K-413 Building \\ 9. L-631 Building \\ 10. K-633 Building \\ 11. Powerhouse Buildings \\ K-701 Boiler House \\ K-702 Turbine Room \\ K-703 Powerhouse Auxiliary Building \\ K-705-B Crib House \\ K-706 Pump House \\ K-707 Auxiliary Switch House \\ 12. K-724 Building \\ 13. K-735 Warehouse Building \\ 14. K-762 Switch Yard \\ 15. K-792 Electrical Switch Yard \\ 16. K-832 Pump hiouse \\ 17. K-862 Recirculating Water Pump House \\ 18. K-892 Recirculating Water Pump House \\ 19. K-1004-L UF 6 Pilot Plant \\ 20. K-1C?4 Building \\ 21. K-103, Building \\ 22. K-1037 Industrial Research Facility \\ 23. K-1066-B UF 6 Cylinder Storage Yard \\ 24. K-1066E UF 6 Cylinder Storage Yard \\ 25. K-1066-J Cylinder Storage Yard \\ 26. K-1066-K Storage Yard \\ 27. K-1131 Building \\ 28. K-1132 Sheds \\ 29. K-1231 Building
}

30. K-1233 Building

31. K-1300 Disposal Stack

32. K-1301 Fluorine Production Facility

33. K-1302 Gaseous Fluorine Storage Facility

34. K-1303 Building

35. K-1401-N Maintenance Shop (NW portion)

36. K-1410 Building

37. K-1413 Engineering Laboratory

38. K-300-C Buildings

39. K-712 Building

40. K-734 Building

41. K-738 Building

42. K-766 Building

43. K-801 Buildings

44. K-833 Building

45. K-834 Building

46. K-891 Building

47. K-1025-E Building

48. K-1401-NB Maintenance Shop (basement)

49. K-1420 Building (floors \& walls)

50. K-1421 Building

51. K-1422 Building

52. K-1501-E Building

53. 1200 Complex-Centrifuge Facility K-797 Switch Gear Room

K-798 Transformer and Switch Gear

K-1004-J Chemical Processing Laboratory

K-1004-O Addition

K-1010 Research Facility

K-1023 Reliability Testing Laboratory

K-1045 Valve Certification Laboratory

K-1052 Laboratory

K-1200 Centrifuge Preparation \& Test Building

K-1210 Centrifuge Test Facility

K-1220 Centrifuge Plant Demonstration Facilities

54. K-1600 Technology/Seismic Test Facility

55. K-709 Electrical Switchyard 


\section{OAK RIDGE NATIONAL LABORATORY}

\section{ENVIRONMENTAL RESTORATION AND WASTE MANAGEMENT FACILITIES}

\section{DESCRIPTION}

The Oak Ridge National Laboratory (ORNL) occupies several sites and covers about 2900 acres in Melton and Bethel Valleys, 10 miles southwest of the city of Oak Ridge, Tennessee. ORNL's mission is to conduct applied research and development (R\&D) in support of DOE programs in fusion, fission, conservation, fossil, and other energy technologies and to perform basic research in selected areas of the physical and life sciences. Past R\&D and waste management activities at ORNL have produced a significant number of RCRA/CERCLA units contaminated with low-level radioactive and/or hazardous chemical wastes that will potentially require remediation. The Oak Ridge Reservation (ORR), which includes ORNL, was placed on the National Priorities List in 1989. The site has been divided up into 15 Waste Area Groupings which will be addressed in accordance with requirements of the January 1992 CERCLA Federal Facilities Agreement signed by the State of Tennessee, DOE, and the EPA. Existing facilities which are no longer in use are being systematically maintained or scheduled for decontamination and decommissioning.

\section{AGREEMENTS}

\section{Statute/Type}

Agreement-in-Principle

CWA/Compliance Agreement

RCRA Land Disposal

Restrictions/Federal

Facility Compliance

Agreement (FFCA)

Toxic Substances

Control Act/FFCA

Clean Air Act, NESHAPS/

Compliance Agreement

CERCLA/Federal Facility

Agreement
Facilities

ORNL,K-25,Y-12

ORNL

ORNL,K-25,Y-12

DOE/EPA

Completed 6/12/92

ORNL, K-25, Y-12 DOE/EPA

Completed 2/20/82

ORNL,K-25,Y-12 DOE/EPA

ORNL,K-25,Y-12 DOE/EPA/TN

\section{$\underline{\text { Status }}$}

Completed 5/13/91

Completed 2/12/86

DOE/EPA
Completed 5/26/92

Completed 1/1/92 


\section{FACILITIES AND PROJECTS}

\section{Waste Management}

\section{T-1: Liquid Low-Level Waste (LLLW) Evaporator Facility}

The LLLW Evaporator Facility (Building 2531) and its Evaporator Storage Tanks are used to reduce LLLW volume by evaporation. Because of limited storage capacity for LLLW, this facility is an integral component in the ORNL LLLW treatment system.

\section{T-2: ORNL Process Waste Treatment Plant (PWTP)}

PWTP treats slightly radioactive process wastewaters generated at ORNL. Radioactivity is removed from the wastewater by ion exchange, before discharge to the Nonradiological Wastewater Treatment Plant (NRWTP) $(\mathrm{T}-4)$.

\section{T-3; Waste Operations Control Center (WOCC)}

WOCC provides automated monitoring and control of liquid and gaseous waste operations for ORNL.

\section{T-4: ORNL Nonradiological Wastewater Treatment Plant (NRWTP)}

NRWTP collects and treats nonradioactive liquid waste streams, as required, to meet the discharge parameters established by the Environmental Protection Agency (EPA) and the state of Tennessee, which are intended to eliminate the discharge of untreated process wastewater into surface impoundments. Approximate facility capacity is 300 gallons per minute (gpm).

\section{T-5; 7831 Compactor Facility}

Compactable solid low-level radioactive waste is reduced in volume and is packaged at this facility for disposal in the Interim Waste Management Facility (IWMF) (D-2).

\section{T-6: Bethel Valley Process Waste Storage Tanks}

Two 350,000 gallon collection tanks function as feed and surge tanks for the PWTP (T-2).

\section{T-7: Melton Valley Solidification Facility}

This facility (Building 7877) solidifies supernatant LLLW from the Melton Valley Storage Tanks (S-2).

Solidification, performed by a private-sector contractor, reduces the total volume of stored LLLW. The solidified material is stored on site pending a decision on final disposal.

\section{T-8: Melton Valley Process Waste Collection Tanks}

These four 100,000 gallon collection tanks function as feed and surge tanks for both PWTP (T-2) and NRWTP $(\mathrm{T}-4)$. 


\section{S-1: Transuranic (TRU) Waste Storage Facilities and Certification Facility}

The TRU Waste Storage Facilities provide storage for contact-handled $(\mathrm{CH})$ and remote-handled (RH) TRU that is awaiting shipment for disposal at the Waste Isolation Pilot Plant (WIPP). The Waste Examination and Assay

Facility (WEAF) provides nondestructive examination of CH-TRU and solid LLW.

\section{S-2: Melton Valley Storage Tanks and Solidification Facility}

The 350,000 gallon Melton Valley Storage Tanks (Building 7830) store LLLW that is generated at ORNL.

\section{S-3: Storage Site for Emergency Avoidance Solidification Campaign (EASC) Storage and Liquid Waste Solidification Project (LWSP I and LWSP II)}

An interim storage facility for storing solidified waste from the 1987 EASC is located near the Mixed Waste Hydrofracture Facility (MWHF). This storage facility was designed specifically for storing cement-solidified LLLW generated by processing 47,000 gal of LLLW. This solidified waste is contained in storage casks designed to provide (1) multiple containment barriers for the solidified waste form, (2) adequate shielding for the highactivity waste, and (3) sampling capabilities for monitoring the possible presence of entrained liquids and gases.

Essentially, LWSP I and LWSP II are the second and third LLLW solidification campaigns at ORNL. LWSP I took place in FY 1992 and processed about 50,000 gallons of LLLW. LWSP II is scheduled for the 3rd quarter of 1993. The solidified waste from these additional campaigns has been stored and will continue to be stored at the same (EASC) site that was used for the first campaign, using the same storage concept.

\section{S-4: 7507 TSCA PCB Storage Facility}

Building 7507 is used to store PCB contaminated wastes. These are stored until shipment for disposal at a permitted commercial facility or at the TSCA incinerator. Storage capacity of this facility is 1000 cubic feet.

\section{S-5: Mixed Waste Storage Pad Facility}

Building $7507 \mathrm{~W}$, located within the ORNL complex, is a covered concrete pad used to store 55- and 30-gallon drums of mixed waste. The total capacity of the pad is 22,000 gallons, or 40055 -gallon drums. Wastes stored here are similar to those stored in Building 7654, consisting of scintillation counting vials that contain organic and inorganic mixtures, contaminated with low levels of radioactivity. Other wastes stored here include organic wastes, carcinogenic wastes, mercury-contaminated solid wastes, waste oils, waste solvents, and other process wastes.

\section{S-6: Chemical Hazardous Waste Storage (7600 Area)}

The 7600 area is comprised of five buildings used to store various hazardous wastes. Building 7651 contains used oil that is classified as hazardous waste. Building 7653 provides lab-pack hazardous waste storage. Building 7666 is an emergency response storage area.

Building 7652 contains hazardous wastes that have been packaged, labeled, and marked in accordance with Department of Transportation (DOT) regulations. Bulk waste chemicals are placed in DOE-approved drums, at their point of origin or after transfer to the facility. A maximum of 15,125 gallons (275 55-gallon drums) can be stored at this facility. All drums stored here are segregated according to RCRA hazard classes. When enough drums have accumulated, they are transferred to an off-site, EPA-approved TSD facility. 
Building 7654 provides long-term storage for mixed waste. The building contains five storage areas for both mixed hazardous and radioactive wastes, most of which are built scintillation fluids and scintillation vials. The majority of mixed wastes are transported to Building 7654 in 55-gallon drums. The maximum inventory of drums in storage at any given time is 300 , with a capacity of 16,500 gallon.

\section{S-7: SWSA 5}

SWSA 5 contains three solid waste management units (SWMUs); the SWSA 5 burial ground, the TRU Waste Storage Area, and the Process Waste Sludge Basin. The SWSA 5 burial ground (south area), now inactive, was opened in 1958 and, like SWSA 4, was used for burial of LLW in trenches. Auger holes were also used for disposal of higher-activity wastes and fissile materials.

The north end of SWSA 5 is used for retrievable TRU wastes. LLW, stored in stainless steel drums, is held temporarily in Building 7823 and then moved to storage in Buildings 7826 (11,000 cubic feet) and 7834 (14,000 cubic feet). Hot-cell wastes are stored in concrete casks in Building 7855 . High-beta/gamma-activity TRU waste is placed in stainless steel containers and held in stainless steel storage wells in Buildings 7827 and 7829.

The Process Waste Sludge Basin is a clay-base, polyvinylchloride (PVC)-membrane-lined basin, approximately 6400 square feet in an area with a maximum depth of 8 feet. The basin, now inactive, was used between 1976 and 1980 as a repository for sludge from the PWTP's water softening processes. The sludge consists primarily of ferrous sulfate and ferrous hydroxide, but also contains some fission products.

\section{LLW Storage Area}

The 7841 LLW Storage Area is a fenced gravel storage yard that was once used to store miscellaneous solid LLW. Official closure is pending.

\section{D-1: Central Radioactive Gas Disposal (CRGD)}

The CRGD facility (Building 3039) is the central stack through which cell ventilation air and process off-gases from the main ORNL complex are discharged. A ventilation upgrade will replace off-gas fans that discharge from Building 7920.

\section{D-2: SWSA 6 Waste Management Facility}

A new radioactive solid waste disposal facility, the IWMF, was constructed in SWSA 6 to provide disposal capability for solid LLW until long-term, line-item facilities become available in the late 1990s. Tumulusdisposal technology is being utilized, with 6 tumulus pads and their associated leachate collection systems in place. SWSA 6 is also the currently active disposal facility for fission-product LLW.

\section{Future Treatment Facilities}

\section{FT-1: Bethel Valley Low-Level Waste System Upgrade}

The Bethel Valley LLW system is to be upgraded, through a proposed line-item project, to serve major LLW facilities at ORNL. The project provides for a new underground LLW pipeline service, new local collection tanks, and new monitoring and control capabilities for discharged wastes. Also, a new Transported Waste Receiving Facility (TWRF), capable of receiving transported waste from a bulk tanker or from bottles will allow for the transfer of that waste to the existing plant LLW system. The Bethel Valley LLW system provides central monitoring and control capabilities for any new L.LW systems at the Laboratory's WOCC (T-3). 


\section{Future Storage Facilities}

\section{FS-1: Nuclear Fuel Services (NFS, Storage Facility}

This facility will store 1,000 drums of plutonium wastes from NFS. It will consist of a prefabricated metal building, approximately 80 feet $\times 50$ feet. The interior will be open with a clear interior height of 15 feet.

\section{FS-2: Waste Characterization and Certification Facility (WCCF)}

This new characterization and certification facility for CH-TRU and low-level wastes will be a 250 feet $x 150$ feet building and will contain the following: building services, a temporary waste-container storage area, a waste inspection bay, the appropriate radiation shielding for the assay and examination instruments in the bay area, automated guidance vehicles for remotely transferring radioactive packages instead of manually moving them between the temporary storage area and the instruments in the waste inspection bay, computer and control rooms, a data storage area, an office complex, and the maintenance area.

\section{ES-3: Class L-III/L-IV Above Ground Storage}

This facility will be designed to meet long-term storage and monitoring requirements for Class L-III/L-IV solid LLW. The facility will consist of above-grade concrete modules that will rest on a bench cut into a hillside on the southern slopes of SWSA 7. The concrete modules will be constructed for long-term storage and for future retrievability of the waste packages.

\section{FS-4: Bulk Contaminated Soil Facility}

This enclosed, prefabricated metal building will store up to 1200 cubic yards of contaminated soil generated by construction activities. The category 2 and 3 soil will be stored in LSA steel boxes. The building will be approximately 50 feet wide and 100 feet long and will be curbed and sumped.

\section{Future Disposal Facilities}

FD-1: Class II Disposal Facility (Will no longer be at ORNL; now included under "LLW Disposal Facilities" in K-25 site Line Item Projects).

This facility will use the tumulus concept for waste disposal. The tumulus concept consists of placing the waste in concrete casks; stacking the casks atop a reinforced concrete pad; entombing the stacked casks and pad within a multimedia, engineered cover; and monitoring the system's performance. The 20 to 40 concrete pads will be at grade. Below-grade galleries between the rows of pads will provide for performance monitoring. Each pad will be approximately 60 feet wide and 90 feet long and will accommodate the stacking of concrete casks to at least 15 feet high, allowing disposal of 30,000 cubic yards of Class II Solid LLW.

\section{FD-2: Class L-III/L-IV Retrievable Storage Facility}

This project will provide storage for an additional two-year inventory of RH LLW after the first Class L-III/L-IV Below Ground Storage Facility is filled. This facility will be located in Melton Valley near existing waste facilities and will be monitored in shielded cells. 


\section{Environmental Restoration}

\section{Waste Area Groupings (WAGs)}

ORNL WAG 1 consists of individual contaminated sites in the main plant area including low-level liquid waste collection and storage tanks; leak and spill sites and contaminated soils; ponds and impoundments; waste treatment facilities; shallow land burial and other solid waste storage areas; and other miscellaneous chemical and sanitary waste facilities.

ORNL WAG 2 contains the area encompassed by the stream channels and flood plains of White Oak Creek, and the area of White Oak Lake, White Oak Dam, and the White Oak Creek Embayment prior to confluence with the Clinch River.

ORNL WAG 3 is composed of a shallow-land burial site, the Solid Waste Storage Area (SWSA) 3, the Closed Scrap Metal Area, and the Contractor's Landfill.

ORNL WAG 4 is composed of three sites: a shallow-land burial ground containing radioactive and hazardous wastes (SWSA 4); two pilot-scale, liquid low-level waste (LLLW) seepage pits; and an inactive LLLW line.

ORNL WAG 5 is composed of 16 contaminated sites, including LLLW transfer lines and leak sites, hydrofracture surface facilities, waste storage tanks, a sludge basin and a holding pond, a shallow land burial ground containing radioactive and hazardous wastes (SWSA 5), and a TRU waste storage area. The major contaminants detected in groundwater seepage are Strontium 90 and Tritium.

ORNL WAG 6 consists of a shallow-land burial site (SWSA 6), the Emergency Waste Basin, and the Explosives Detonation Trench. This 68 -acre site is still in operation as a waste burial ground for solid low-level radioactive waste.

ORNL WAG 7 comprises 17 sites including several LLLW seepage pits and trenches, Homogeneous Reactor Experiment fuel wells, experimental hydrofracture injection areas and surface contamination, shielded transfer tanks, and a decontamination facility.

ORNL WAG 8 is made up of 27 sites which include waste collection basins, LLLW lines and leak locations, and an experimental hydrofracture injection area with associated oil contamination, LLLW collection/storage tanks, a hazardous waste storage facility, a mixed waste storage pad, a sewage treatment plant, and a silver recovery plant. Various radioactive contaminants have been used at these units, but very few releases have been reported or identified as being above background levels.

ORNL WAG 9 is made up of six sites: the Homogeneous Reactor Experiment (HRE) Pond, two inactive LLLW collection and storage tanks, a trash area, the Waste Evaporator, and the Waste Evaporator Loading Pit.

Contamination is mainly from radionuclides.

ORNL WAG 10 consists of the injection wells and grout sheets associated with two hydrofracture process experimental locations, the Old Hydrofracture Facility, and the New Hydrofracture Facility. The surface facilities themselves are associated with WAGs 5,7 , and 8.

ORNL WAG 11 is the White Wing Scrap Yard, an area of about 20 acres used to store contaminated materials from the three Oak Ridge plants. Wastes (equipment, tanks, and trucks) were rf ported to have been stored above ground. Much of the stored materials and contaminated soil was removed in 1966-1971; however, some scrap metal, concrete, and other waste remains and is being removed as an interim action. 
ORNL WAG 13 consists of a Cesium- 137 contaminated field and the Cesium-137 Erosion/Runoff Study Area. The 50-acre area was set aside to study simulated fallout of Cesium 137, which would occur in the event of a nuclear war. Cesium 137 contaminated soil is being removed as an interim action.

Bethel Valley Groundwater OU contamination is limited to waste areas in the vadose and shallow groundwater zones. There is no known contamination of the deep groundwater zone. Contaminants of concern include strontium, tritium, and organic compounds.

Melton Valley Groundwater OU contamination, with the exception of WAG 10, is limited to waste areas in the vadose and shallow groundwater zones, and in groundwater discharge via seeps to the White Oak Creek and White Oak Lake. Contaminants of concern in Melton Valley include strontium, cesium, and tritium.

\section{Decontamination \& Decommissioning Facilities}

\section{X-10 Site Bethel Valley}

The 3001 ORNL Graphite Reactor (OGR) was an air-cooled, graphite moderated and reflected, heterogenous, natural -uranium-fueled reactor. It was operated for 20 years between 1943 and 1963. The OGR facility includes the 3001 ORNL graphite reactor, 3002 OGR filter house, 3003 OGR fan house and 3018 exhaust stack (for 3003).

The 3005 Low-Intensity Test Reactor (LITR) was a water-moderated and water-cooled, beryllium and water reflected research reactor designed for use as a reflector. It was operated from 1951 to 1968. The LITR facility includes the 3005 low-intensity test reactor and the 3077 cooling tower (for LITR).

The 3042 Oak Ridge Research Reactor (ORR) was a light-water-moderated and cooled, beryllium and water reflected research reactor designed for use as a general purpose research tool. The reactor was operated for 29 years, between 1958 and 1987. The ORR facility includes Building 3042 and associated experimental facilities and ORR heat exchanger in Building 3087.

The 3505 Metal Recovery Facility (MRE) was a pilot- and small-scale production nuclear fuel reprocessing plant used for the processing of various waste solutions, scrap and miscellaneous fuel elements for the recovery of uranium, plutonium, neptunium and americium. The facility was operated from 1952 to 1960.

The 3506 Waste Evaporator Facility (WEF) received the LLW waste streams from ORNL laboratories and other processing areas for concentration prior to final disposition by shale fracture techniques. The facility operated from 1949 until 1954.

The 3515 Fission Product Pilot Plant (FPPP) was used in the fission product recovery development program for the separation of curie quantities of various radionuclides from LLW waste streams. It was operated from 1948 until 1958.

The 3517 Fission Product Development Laboratory (FPDL) was originally designed to separate kilocurie quantities of ${ }^{137} \mathrm{Cs},{ }^{90} \mathrm{Sr},{ }^{144} \mathrm{Ce}$ and ${ }^{147} \mathrm{Pm}$ from Redox- and Purex-type waste streams. The facility was modified to allow production of megacurie amounts of ${ }^{137} \mathrm{Cs},{ }^{90} \mathrm{Sr}$, and ${ }^{144} \mathrm{Ce}$, primarily for the AEC SNAP program. The facility operated from 1958 until 1975.

The 4507 High-level Chemical Development Laboratory was a laboratory and small-scale pilot plant for development studies of reactor fuel processing, separation, and recovery of transuranic materials and separation of fission products from aqueous wastes. The facility operated from 1957 until 1980. 
The Shielded Transfer Tanks were used for the shipment of ${ }^{137} \mathrm{Cs}$-loaded ion exchange resins from Richland, Washington to ORNL for processing. The resins were rinsed at the conclusion of operation and the ${ }^{137} \mathrm{Cs}$ converted to a usable form at the FPDL. The tanks still containing their resins are located at the 7819 Decontamination Facility and were used from 1958 until 1970.

\section{X-10 Site Melton Valley}

The 7500 Homogeneous Reactor Experiment (HRE) was an experimental aqueous homogeneous reactor developed for nuclear power application analysis. The reactor operated between 1957 and 1961. The HRE facility includes the 7500 Homogeneous Reactor Experiment and HRE-related facilities in other buildings: 7502 waste evaporator, 7554 cooling tower, 7557 charcoal absorber pit, 7558 waste evaporator loading pit, 7559 charcoal absorber valve pit, and 7561 decontamination pad.

The 7503 Molten Salt Reactor Experiment (MSRE) was a single-region, unclad-graphite-moderated, homogenoeous-fuel reactor built to investigate the practicality of the molten salt reactor concept for central power station applications. It was operated from 1965 to 1969 . The MSRE facility includes the 7503 building and MSRE-related facilities in other buildings: 7511 filter pit, 7512 exhaust stack, 7513 cooling tower, 7514 supply air filter house, and the 7555 diesel generator house.

The 7852 Old Hydrofracture Facility (OHE) was an experimental and operational plant for the injection of waste grout into a fractured shale formation. The plant was tested and operated during 1964 to 1980.

\section{Y-12 Site}

The Molten Salt Corrosion Loop equipment is located in Building 9201-3, Room 235 at Y-12. The facility was used for preparation and handling of fuel for molten salt reactor technology development and the MSRE. It was also used to produce fuel salts for the Molten-Salt Breeder Reactor development program. The facility operated from 1958 until 1976.

The 9201-3 Coolant Salt Technology Facility was used to support the development of molten salt reactor technology and specifically for studying the effects of injecting tritium into a flow of boron triflouride. The facility is located in Building 9201-3, second floor at Y-12. The facility operated from 1958 until 1976.

The 9419-1 Decontamination Facility was used to decontaminate equipment and materials associated with the development of molten salt reactor technology. It was from 1958 until 1976.

The Storage Tank is located in Building 9201-3 at Y-12,The tank was used as a reservoir for machine shop cutting oil during the development of molten salt reactor technology. It was used from 1958 until 1969. 


\section{OAK RIDGE NATIONAL LABORATORY WASTE MANAGEMENT SITE MAP}

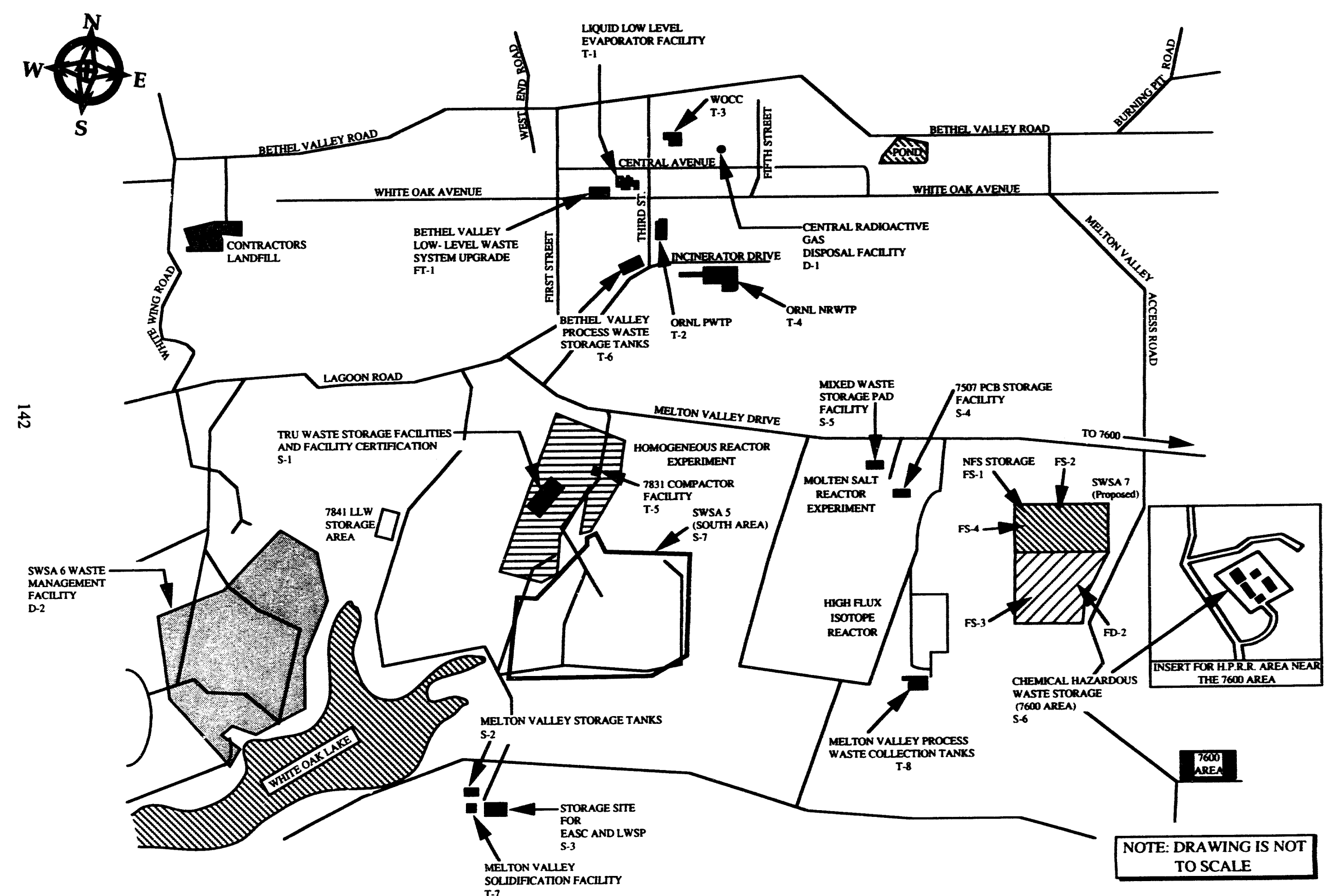




\section{OAK RIDGE NATIONAL LABORATORY}

WASTE AREA GROUPINGS

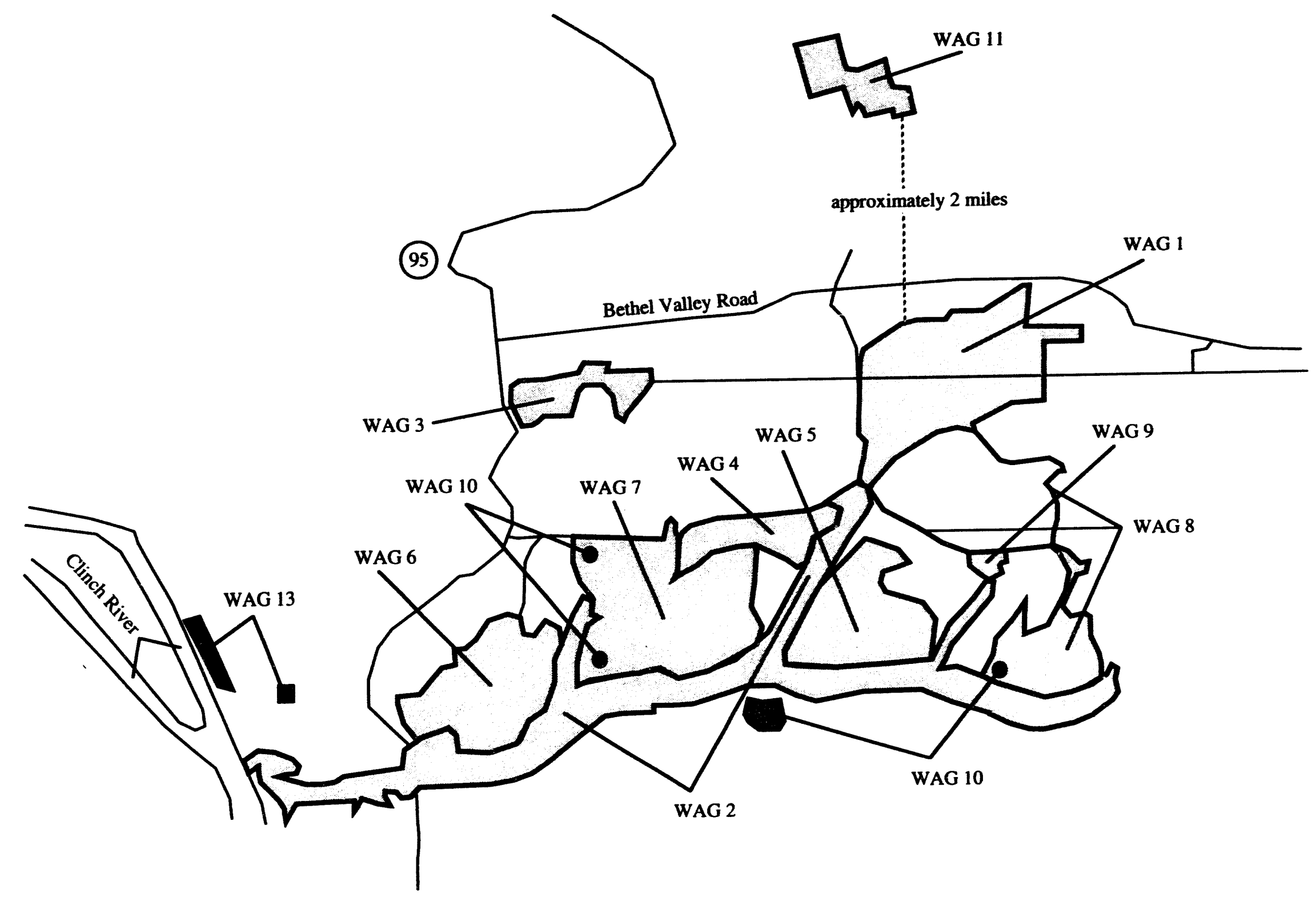




\section{OAK RIDGE NATIONAL LABORATORY}

GROUNDWATER OPERABLE UNITS

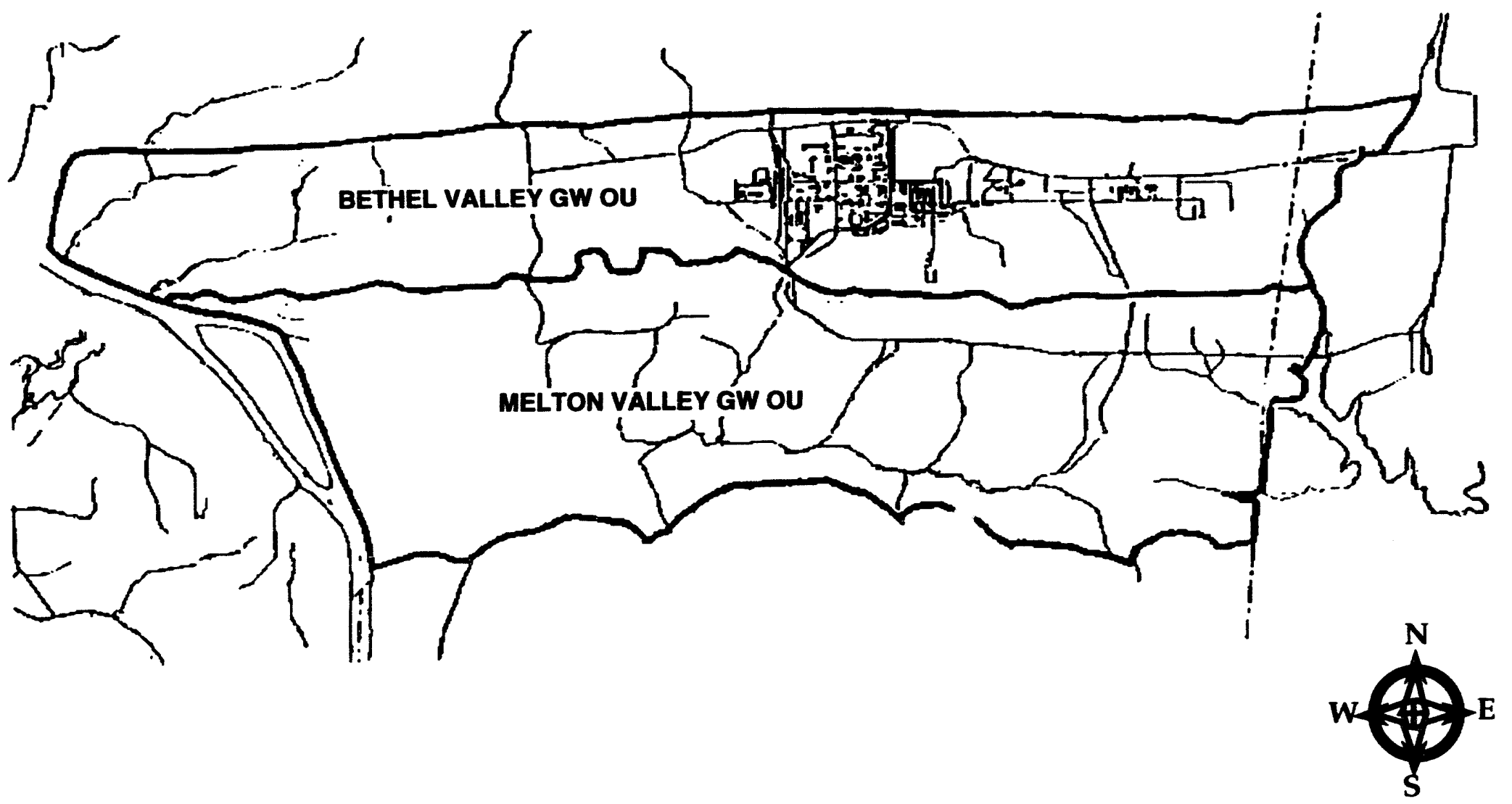




\section{OAK RIDGE NATIONAL LABORATORY \\ DECONTAMINATION \& DECOMMISSIONING FACILITIES ORNL X-10 SITE BETHEL VALLEY}

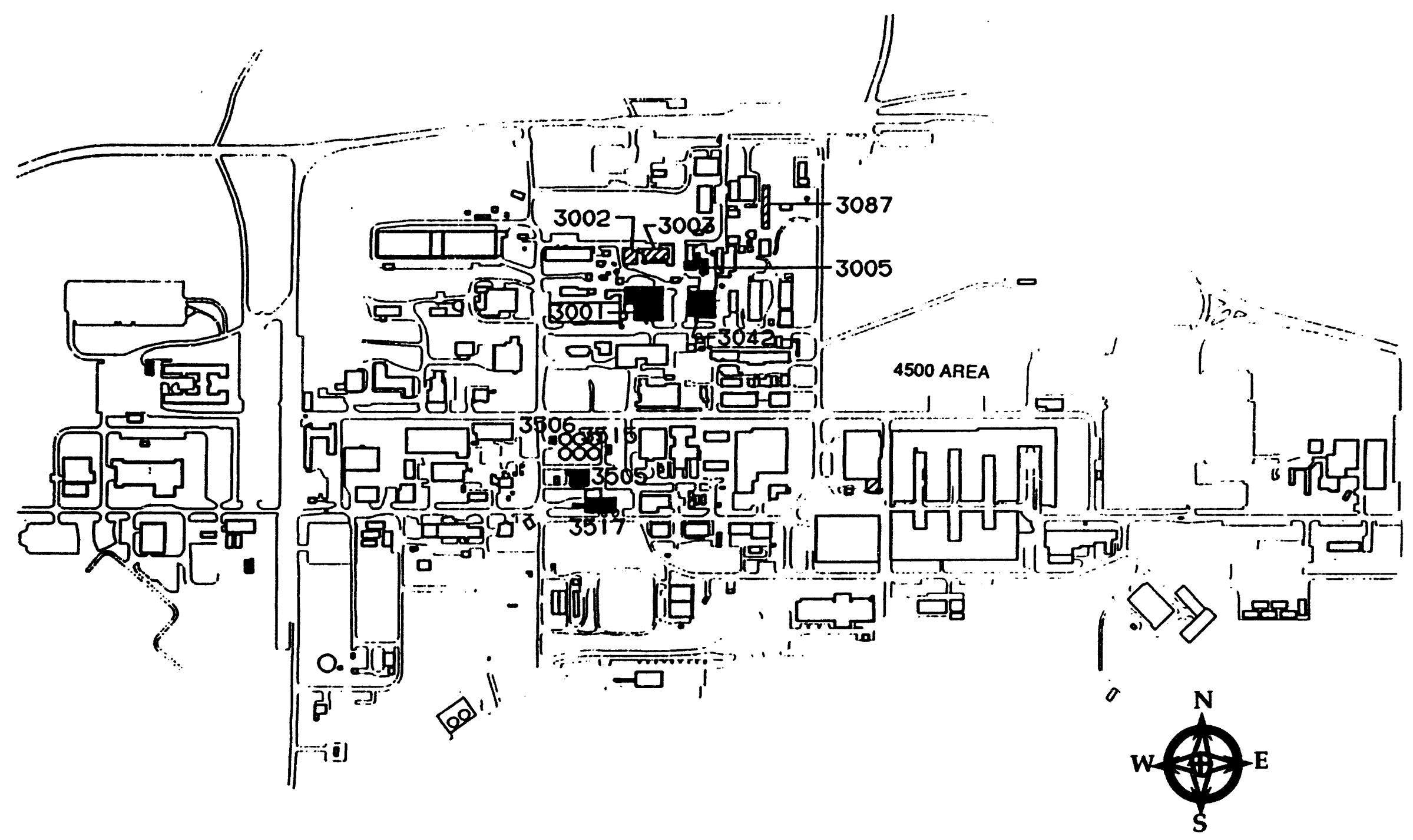


OAK RIDGE NATIONAL LABORATORY

DECONTAMINATION \& DECOMMISSIONING FACILITIES

ORNL X-10 SITE MELTOI VALLEY

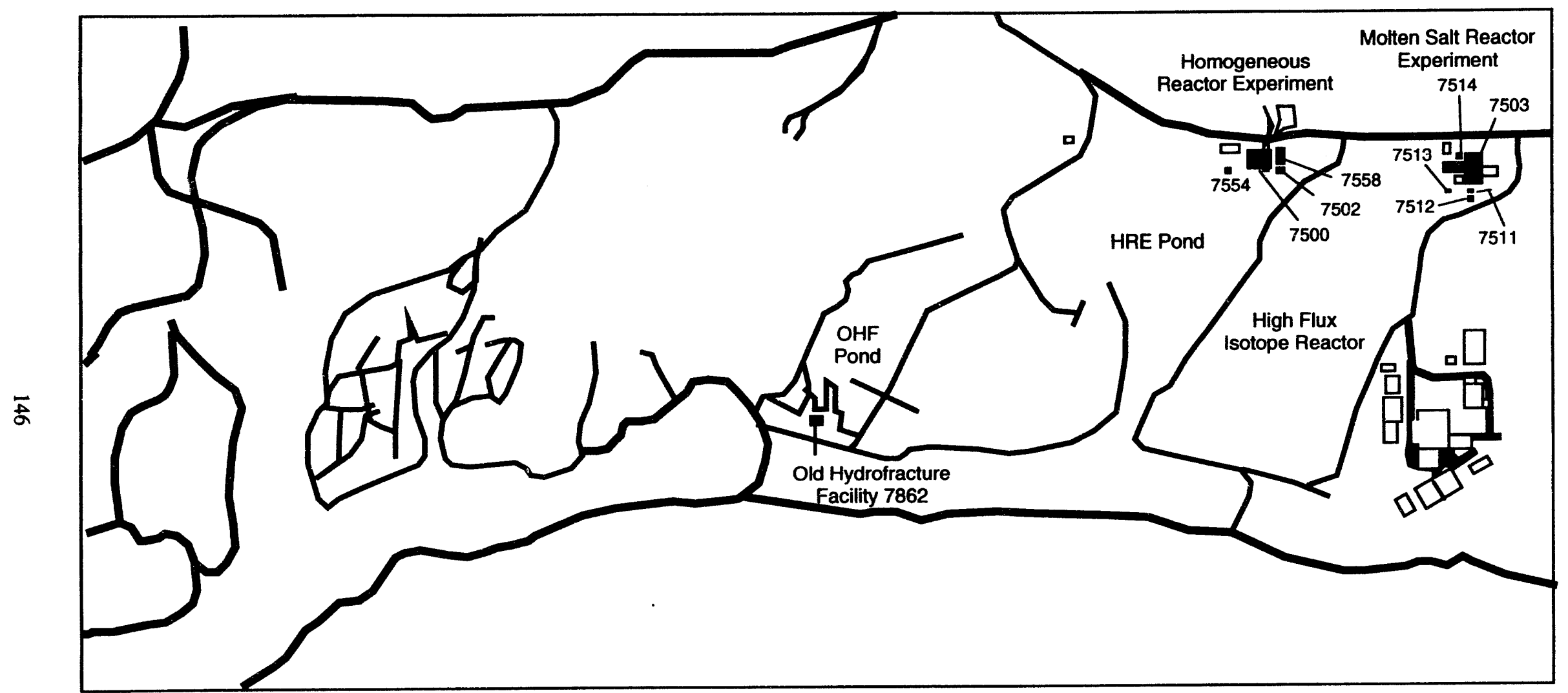

X-10 D\&D Accepted Facilities

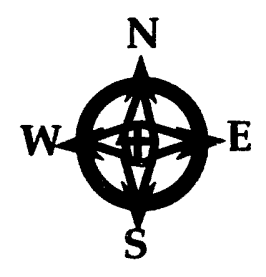


OAK RIDGE Y-12 PLANT

ENVIRONMENTAL RESTORATION AND

WASTE MANAGEMENT FACILITIES

\section{DESCRIPTION}

The Oak Ridge Y-12 Plant occupies an 811-acre site in the Bear Creek Valley about 2 miles southwest of the City of Oak Ridge, Tennessee. The site is drained by Bear Creek and East Fork Poplar Creek. The plant was established to separate uranium isotopes by an electromagnetic process. When the process was discontinued after World War II, the Y-12 Plant's mission changed to manufacturing and developmental engineering. The Y- 12 Plant contains many facilities that have been used for treating, storing, or disposing (TSD) of hazardous and radioactive materials and wastes. A significant component of the current site mission consists of conducting investigations for identification and remediation of environment contamination stemming from prior operations. The Oak Ridge Reservation (ORR), which includes the Y-12 Plant, was placed on the National Priorities List (NPL) in 1989. Y-12 has been divided into 13 operable units which will be addressed in accordance with requirements of the January 1992 CERCLA FFA signed by the state of Tennessee, DOE, and the EPA. Existing facilities which are no longer in use are being systematically maintained or scheduled for decontamination and decommissioning.

\section{AGREEMENTS}

\section{Statute/Type}

Agreement in Principle

RCRA Land Disposal

Restriction/ Federal Facility

Compliance Agreement

(FFCA)

Clean Air Act, NESHAPS/

Compliance Agreement

CERLCA/Federal Facilities

Agreement

Clean Water Act/

Compliance Agreement

Toxic Substances Control

Act/FFCA
Facilities

ORNL, K-25, Y-12

ORNL, K-25, Y-12

ORNL, K-25, Y-12

ORNL, K-25, Y-12

ORNL, K-25, Y-12

ORNL, K-25, Y-12
Parties

DOE/Tenn.

$\underline{\text { Status }}$

Completed 5/13/91

DOE/EPA

DOE/EPA

Completed 4/14/82

DOE/EPA/Tenn.

Completed 1/1/92

DOE/EPA

Completed 4/17/85

DOE/EPA

Completed 2/20/92 


\section{FACILITIES AND PROJECTS}

\section{Waste Management}

\section{Building 9616-7, West End Treatment Facility (WETF) and West Tank Farm (WTF)}

The WETF and the WTF, are designed to treat 2.7 million gallons per year of nitrate-bearing wastes from Y-12 production operations and to store the resulting sludge. The waste streams treated at the WETF and WTF consist of nitric acid wastes, nitrate-bearing rinsewaters, mixed acid wastes, and biodenitrification sludges.

Solids and sludges generated from wastewater treatment in the WETF and the WTF systems are stored in five 500,000 -gallon storage tanks until a long-term solution can be developed and approved for disposal of such mixed waste. Treated wastewaters are discharged into East Fork Poplar Creek through a National Pollutant Discharge Elimination System monitoring station.

\section{Building 9401-5. Uranium Chip Oxidation Facility (UCOF)}

The UCOF is designed to thermally oxidize, under controlled conditions, depleted and natural uranium machine chips to obtain a disposable, stable uranium oxide. Upon arrival at the facility, the chips are weighed, transported to an oxidation chamber, and emptied onto a feed table. The chips are ignited in the oxidizer and are converted into uranium oxide. After oxidation is complete, a screw conveyor transfers the uranium oxide into 55-gallon drums. The filled drums are transported to the Uranium Oxide Storage Vaults and are placed in retrievable storage.

\section{Building 9416-10. Waste Coolant Processing Facility (WCPF)}

WCPF receives, stores, and treats biodegradable, waste machine-coc'ants from machining operations in the Y-12 Plant. Typical wastes received are dilute solutions of waste machine-coolants, containing mineral oil, chlorinated paraffins, and long-chain fatty acids. Wastes are treated in an extended aeration reactor, where biological activity is allowed to proceed under conditions that maximize organic removal and that minimize sludge production. Solids are dried and packaged in drums for further treatment; liquid effluent is transferred to WETF or to the Central Pollution Control Facility (CPCF) for further treatment.

\section{Building 9623. Central Pollution Control Facility (CPCF)}

The CPCF is designed to treat annually a flow of 2.7 million gallons of non-nitrate-bearing wastewater from the Y-12 Plant. These treated wastewaters are fully analyzed, and are categorized as

(1) diluted wastewater, wastewater, or mopwater,

(2) acidic wastes,

(3) caustic wastes,

(4) hydrogen fluoride scrubber wastes, and

(5) plating rinsewaters.

These general categories of waste cover a broad range of chemical compositions and concentrations, and may include significant quantities of heavy metals, acids, bases, and organics. The treated effluent from CPCF is discharged to East Fork Poplar Creek through an NPDES monitoring station. CPCF operates as one of the two primary wastewater treatment facilities at the Y-12 Plant, and is tied to the operation of the Plating Rinsewater Treatment Facility (PRTF). 


\section{Building 9623, Plating Rinsewater Treatment Facility (PRTF)}

The part of the PRTF proces; that neutralizes incoming rinsewaters and that provides equalization volume is located in a diked, outdoor bissin across the street from Building 9401-2, the Plating Shop, which produces most of the plating rinsewaters treated at the facility, and is adjacent to the CPCF. The remainder of the process shares space with the CPCF in Building 9623. Designed to treat diluted plating rinsewaters, primarily contaminated with heavy metals like chromium, copper, nickel, and zinc, the PRTF also has unit operations to treat cyanide-bearing wastes. The annual hydraulic loading on the facility was projected to be $8 \mathrm{M}$ gal; however, since start-up in 1987 , the actual annual waste loading has been approximately one million gallons.

\section{Building 9401-4. (Compactor) Y-12 Waste Feed Preparation Facility (WFPF)}

At the WFPF, low-level waste is packaged and stored before shipment to the K-25 Site, where it is placed in longterm storage. A 200-ton capacity waste baler is dedicated to the compaction of low-level waste. The waste is brought into the facility from areas either known to generate contaminated waste or from dumpsters that have been through the Trash Monitoring Station and are found to be above acceptable limits for disposal in the sanitary landfill. Waste from dumpster pans are put through the baler for an average volume reduction of 8:1. Compacted bales are placed in B-25 boxes and are staged in an adjacent warehouse before monitoring, shipment, and storage at K-25.

\section{Liquid Storage Facility (LSF)}

The LSF is a collection of pretreatment stations for groundwater from the Bear Creek Burial Grounds (BCBG), located in the burial ground area. The final treatment processes take place at the Groundwater Treatment Facility (GWTF), located at the west end of the Y-12 Plant in an addition to the WETF building. LSF provides a final filtration step for the separation of PCB-contaminated oils and water. Located in a reinforced concrete diked area, LSF contains two 250,000-gallon storage tanks, a 100-gallon-per-minute gravity separator, duplex cartridge filters, one 6000-gallon tank, and truck transfer station. The diked area can contain a spill of the largest tank plus a 7" rainfall.

\section{Building 9616-7. Groundwater Treatment Facility (GWTF)}

The GWTF is designed to remove volatile and nonvolatile organic compounds like PCBs from water collected in the LSF, and was built under the Disposal Area Remedial Actions (DARA) restoration programs to collect and treat contaminated groundwater from BCBG and the S-3 Ponds. The two main unit operations in use are air stripping for the removal of volatile organics and carbon absorption for removal of nonvolatile organics. The effluent from the facility is released through an NPDES discharge point to Upper East Fork Poplar Creek that is separate from the WETF discharge point.

\section{Building 9720-44, Sludge Handling Facility}

Located on Chestnut Ridge, south of Y-12, this currently inactive drying facility was used to dewater sewer sludges. The facility contains a recieving tank, four multimedia drying racks, and a storage area.

\section{Building 9720-28, Y-12 Waste Material Preparation Facility}

The Waste Material Preparation Facility provides temporary storage for solid waste generated by Y-12 plant operations and waste that is compacted in Building 9104-4. The wastes consist of diversified uraniumcontaminated solid wastes from within Y-12, including paper, lumber, metal, and related items. Processing is done through the size-reduction equipment in Building 9104-4, which includes a waste baler and a strapping head. 
Building 9825-1,2, Uranium Oxide Storage Vaults

Two depleted uranium oxide storage vaults, each constructed of reinforced concrete and with a storage capacity of 32,000 cubic feet, are located on Chestnut Ridge, northeast of Building 9213. These vaults provide a retrievable storage repository for depleted uranium metal and uranium oxide. Depleted uranium metal and uranium oxide are delivered to the vaults as solid depleted uranium, on pallets or in containers, or as depleted uranium oxide powder in sealed 30- and 55-gallon drums on pallets. The containers have a weight limit of 850 pounds.

\section{Building 9720-31, RCRA Staging and Storage Facility}

The RCRA Staging and Storage Facility provides interim storage of drums and smaller containers, in preparation for off-site disposal. Seven drum-storage rooms, each with separate ventilation, store different classes of hazardous waste, and seven rooms with shelving are used for storing and preparing small containers for shipment. All rooms meet both RCRA and TSCA storage guidelines.

\section{Building 9720-25. Classified Waste Storage and Waste Baler}

Building 9720-25 was upgraded to permit storage of approximately 12,000 cubic feet of classified, low-level and mixed waste. Volume-reduction capability is provided by a waste baler.

\section{Building 9811-1. Waste Oil and Solvent Storage and Organic Liquid Storage Area (OLSA)}

Building 9811-1 is a RCRA storage facility consisting of two storage areas, one for tanks (Oil Dike [OD]-7) and the other for containers (OD-8). OD-7, a tank storage dike built several years ago, contains two 30,000-gallon tanks, one 10,000-gallon tank, two 3000-gallon tanks, associated piping and pumps, and an oil and water separator; it is being modified to contain the four tanks from the Building $9409-5$ basin. OD- 8 is an enclosed container storage area adjacent to OD-7 used for storing containerized nonflammable materials. Waste oil and waste solvent collected from production and maintenance areas of the plant are transported to OD-8 in 55-gallon drums, or in 300-gallon "tuff" tanks, for sampling and temporary storage while awaiting the results of the sample analysis, which may itself take as long as six months. Exterior walls were installed at OD-8 in the summer of 1989. Part of the project also included a general fire protection and safety upgrade to meet operational requirements.

\section{Contaminated Scrap Metal Storage (CSMS)}

CSMS is an area in the existing Y-12 Plant salvage yard that is used to store uranium-contaminated scrap metal.

\section{Building 9720-9. Mixed and PCB Waste Storage}

The western half of Building 9720-9 is designated for storage of hazardous, PCB, and mixed wastes. The capacity of the facility is about 1500 drums. Current plans are to upgrade the eastern half of the building to meet hazardous waste storage requirements.

\section{Building 9404-7, PCB Waste Storage}

The PCB Waste Storage building stores up to 200 drums of PCB and mercury waste. Currently, it contains uranium-contaminated waste awaiting disposal in the TSCA incinerator at $\mathrm{K}-25$.

\section{Building 9720-44, Low-Level Waste Storage}

A concrete pad associated with the Sludge Handling Facility (see Y-12 T-12) on which containerized LLW is stored. 


\section{Containerized Waste Storage Area (CWSA)}

The CWSA consists of three curbed concrete pads, with two movable roofs, for the storage of containerized mixed and hazardous wastes. Two of the pads are operational and each pad can store about 800 drums.

\section{East Chestnut Ridge Waste Pile (ECRWP)}

The ECRWP (under temporary closure, with a soil and grass cover) consists of a PVC-lined pit. It is a RCRApermitted facility used for storage of mixed-waste solids, and is equipped with rainwater and leachate collection systems.

\section{Organic Liquid Storage Area \#9 (OD-9)}

OD-9 is hazardous waste storage facility operating under RCRA and TSCA permits. The concrete diked area of the facility has pads to support six 40,000-gallon storage tanks, although only five tanks are currently installed.

Two of these tanks are designated for PBC storage while the other three are used for RCRA liquid wastes. Five centrifugal transfer pumps are provided for loading and unloading material from the tanks to tanker trucks at the tanker transfer station, an integral part of this facility. In addition, a diked and covered drum storage area for 65 55-gallon drums has been provided at the northeast corner of the facility. Due to the anticipated lack of disposal outlets for uranium-contaminated organic liquids, current plans are to use of this facility through the year 2010.

\section{Organic Liquid Storage Area \#10 (OD-10)}

OD-10 contains two 3000-gallon tanks for storage of recyclable solvents, and four, 6500 -gallon tanks for waste flammable liquids. These are the only tanks at Y-12 designed for storage of flammable liquid wastes.

\section{0-2, 3, 4, 5, 6, 7 Above-Grade Storage Pads (AGSP)}

AGSP is a series of above-ground, covered concrete pads for storing solid LLW. Each pad, which can contain about 440 B-25 boxes, includes a liquid collection system and a monitoring station for volume measurement and for sampling.

\section{0-41 New Salvage Yard}

The New Salvage Yard is an area of about five acres that is located west of Y-12 and north of Bear Creek Road used for managing uncontaminated scrap metal. The yard is fenced, is paved with gravel and asphalt, and also contains an operations building.

\section{Construction Spoil Area 1}

This area is a shallow land burial unit used for the disposal of uncontaminated rubble and construction spoils. This facility is not accepting waste.

\section{Industrial Landfill IV (ILF IV)}

The Classified Waste Landfill, ILF IV, provides for disposal of nonradioactive, nonhazardous solid classified wastes. The facility is operated in accordance with the Tennessee Department of Environment and Conservation (TDEC) rules and regulations for land disposal of solid wastes. Estimates have shown that approximately 30 percent of the classified wastes generated at $Y-12$ can be disposed in this landfill. However, this landfill may not meet the solid waste regulations recently promulgated by the State. 


\section{Sanitary and Industrial Landfill II (ILF II)}

This disposal site is located on Chestnut Ridge near the eastern end of the plant and serves $\mathrm{Y}-12$, ORNL, K-25, and other DOE prime contractors in Oak Ridge. The facility operates under a permit from the Tennessee Department of Environment and Conservation (TDEC) and uses shallow land burial with a large trench. The permit allows for special waste disposal including asbestos, aerosol cans, materials contaminated with beryllium oxide, glass, fly ash, coal pile runoff sludge, empty pesticide containers, and SPWTF (T-8) sludge. Requests are filed with the TDEC to allow or the disposal of additional materials as the need is identified. However, disposal space in this landfill is rapidly being exhausted with depletion being projected for FY 1994.

\section{Building 9824-4, Trash Monitoring Station}

The Trash Monitoring Station monitors solid low-level and mixed waste that is generated on-site for the presence of uranium and other radioactive isotopes. The facility uses sodium iodide detectors and multichannel analyzers for detection.

\section{Civic Center Waste Pile (Industrial Waste Landfill III)}

The East Chesnut Ridge Barrow Area Waste Pile is a plastic-lined pit with provision for collecting rainwater and leachates. It is used for the sludge of mixed waste solids.

\section{Interim Reactive Waste Treatment Unit}

The Interim Reactive Waste Treatment Unit located at the Bear Creek burial ground is utilized to treat reactive waste.

\section{0-12 Warehouse 12}

The Material Access Area Storage Warehouse (Warehouse 12) is utilized for the storage of classified waste generated at Y-12. It also houses the Crated Waste Assay Monitor (CWAM) which is being developed to perform Non-Destructive Assay of B-25 boxes.

\section{0-58 RCRA and PCB Container Storage Area (Transformer Shed)}

PCB contaminated electrical equipment (transformers, capacitors, switchgear, etc.) is stored in Building 9720-58. This building is a warehouse facility utilized to stage and store PCB-contaminated equipment and RCRA mixed waste. Waste containers received include 30- and 55-gallon drums, 330- and 660-gallon portable tanks, B-25 boxes, and self-contained PCB equipment. An overhaul of the fire suppression system is planned to meet DOE Order 5480.7 requirements. In addition, improved ventilation and diking systems will be added during 1993 to conform with RCRA and TSCA standards. The facility is about 80 percent full and is still accepting waste.

\section{Uranium Oxide Monitoring Shed}

The Uranium Oxide Monitoring Shed is the personnel monitoring station for the Uranium Chip Oxidation Facility. This station is part of the Uranium Oxide Storage Vaults. 


\section{Y-12 Plant Operable Units (OUs)}

Upper East Fork Poplar Creek (EEPC) OU1 consists of both surface water and groundwater in the hydrogeologic system covered by the industrial area of the Y-12 Plant. Creek sediments are part of this OU. Areal contamination of soils identified by sampling the storm sewer system are also included.

Upper EFPC OU 2 is the Abandoned Nitric Acid Pipeline, which was used between 1951 and 1983 to transport a waste stream made up of nitric acid and depleted uranium from Building 9215 to the S-3 Ponds for disposal.

Upper EFPC OU 3 consists of the S-2 Site; the area around Building 81-10; the Coal Pile Trench; the Salvage Yard Oil and Oil/Solvent Storage Areas, Scrap Metal Storage Area, and Drum Deheader.

Bear Creek OU 1 consists of the S-3 Ponds, Sanitary Landfill I, Boneyard/Burnyard, the Oil Landfarm, and the Bear Creek Burial Grounds, including Oil Retention Ponds 1 and 2. These units were used until the 1980s as the primary area for the disposal of various types of hazardous and nonhazardous wastes generated at the Y-12 Plant.

Bear Creek OU 2 consists of the Rust Spoil Area, Spoil Area 1, and the SY-200 Yard. The Rust Spoil Area was used from 1975 to 1983 for disposal of spoil material generated during various renovation, maintenance, and construction operations at the Y-12 Plant. Small quantities of solvent-contaminated material and material containing asbestos, mercury, and uranium may have been disposed of in this area. Spoil Area 1 contains some construction material which may have been contaminated with trace amounts of asbestos, mercury, beryllium, thorium, and uranium. The SY-200 Yard containing materials from several Y-12 and ORNL divisions including PCB transformers, leading shielding plates, and radioactively contaminated materials. Soil contamination is of primary concern.

Bear Creek OU 4 addresses contamination within the coupled groundwater/surface water system and downstream transport of Bear Creek channel deposits and flood plain sediments. The primary groundwater contaminants are nitrates, VOCs, radionuclides, and to a lesser extent, trace metals. Dense, nonaqueous-phase liquids consisting primarily of perchloroethylene, trichloroethylene, 1,1,1-trichloracetic acid, and high concentration of PCBs have been discovered at a depth of 270 feet below the Bear Creek Burial Grounds. Bear Creek has received contaminated surface water and groundwater discharges from past waste management practices. Principal contaminants remaining in floodplain soils and sediments are PCBs, uranium, and cadmium.

Chestnut Ridge OU 1 is the Chestnut Ridge Security Pits Hazardous Waste Disposal Unit which consists of a series of trenches that were used for the disposal of classified hazardous and nonhazardous wastes. Ten major categories of unclassified wastes have been identified: acids, fiberglass, beryllium, biological material, debris, heavy metals, inorganics, organics, thorium, and uranium.

Chestnut Ridge OU 2 consists of the Filled Coal Ash Pond and Upper McCoy Branch. The Filled Coal Ash Pond was constructed in 1955 to serve as a settling basin for coal ash from the Y-12 steam plant. By 1967, the pond filled, spilling sediments directly into $\mathrm{McCoy}$ Branch. Impacts to surface water, stream sediments, and groundwater from metals, including uranium and major ions, are of concern.

Chestnut Ridge OU 3 is the United Nuclear Corporation (UNC) Disposal Site which received drums of nitrate sludge fixed in cement, drums of contaminated soil, and wooden boxes of contaminated building and demolition materials. 
Chestnut Ridge OU 4 consists of Rogers Quarry and Lower McCoy Branch. The quarry was the source of construction materials in the 1940s and 1950s. It filled with water, and was abandoned in the early 1960s. Flyash and bottom ash from the Y-12 steam plant were placed into the quarry in the 1960s, and bottom ash continues to be disposed of in the quarry via a sluice pipe across Chestnut Ridge. The quarry was also used for disposal of other plant process materials. Lower McCoy Branch begins at the surface water discharge point of Rogers Quarry and ends at the McCoy Branch embayment in the Clinch River/Melton Hill Lake. Impacts to surface water, stream sediments, and groundwater from metals, including uranium and major ions, are of concern. Biomonitoring of aquatic organisms in Rogers Quarry has shown a biological impact potentially from ash disposal operations.

\section{Oak Ridge Y-12 Plant Decontamination \& Decommissioning Facility}

The large Building 9201-4 houses a former mercury solvent extraction process used for lithium isotope separation. The process equipment consists of separation columns and associated pumps, piping, trays and tanks. The process operated during the late 1950s and early 1960s. 


\section{Y-12 WASTE MANAGEMENT SITE}

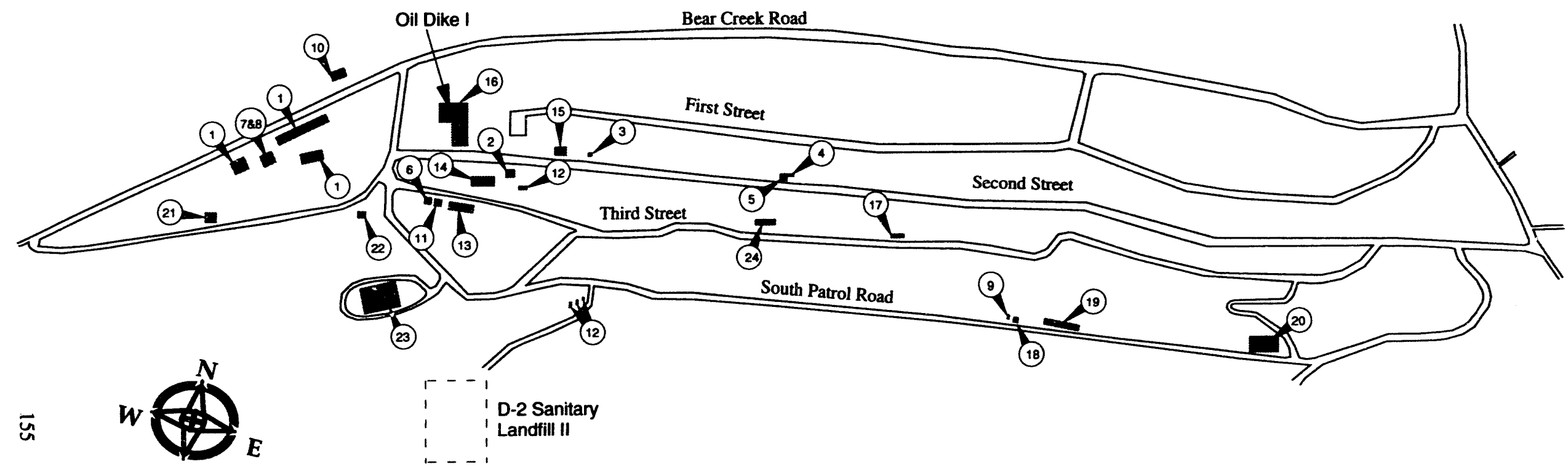

$S$

\section{MAP \# \& NAME}

1. West End TREatment Faclirty (WETF) and WESt TANK Farm

2. URANIUM ChIP OXIDATION FACIIITY

3. Waste Coolant Processing faciutty

4. Central pollution Control factlity

5. Plating Rinsewater Treatment FaCiltTy (PRTF)

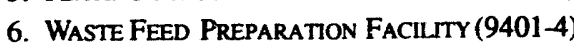

7. LIQUID STORAGE FACILITY

8. Groundwater Treatment Facility

9. SLUDGE HANDLING FACLITY
MAP\# \& NAME

10. INDUSTRIAL WASTE COMPACTION FACILTTY

11. Waste Material Preparation Faciltty

12. Uranium Oxide Storage Vaults

13. RCRA Staging \& StORAge FaCiltTY

14. Classified Waste Storage

15. Waste Oll/SOlvent Storage/Organic LiQuid STORAGE FEA \#7

16. Contaminated Scrap Metal Storage (CSMS)

17. PCB WASTE STORAGE

\section{MAP\# \& NAME}

18. LOW LEVEl WASTE STORAGE AREA

19. Containerized Waste Storage Area (CWSA)

20. East Chestnut Ridge Waste Plle (ECRWP)

21. O RGanic LiQuid STORAGE AREa

22. Construction Spoll area I

23. INDUSTRIAL LANDFILL IV (ILF IV)

24. MIXED/PCB WAsTE STORAGE 


\section{Y-12 OPERABLE UNITS}

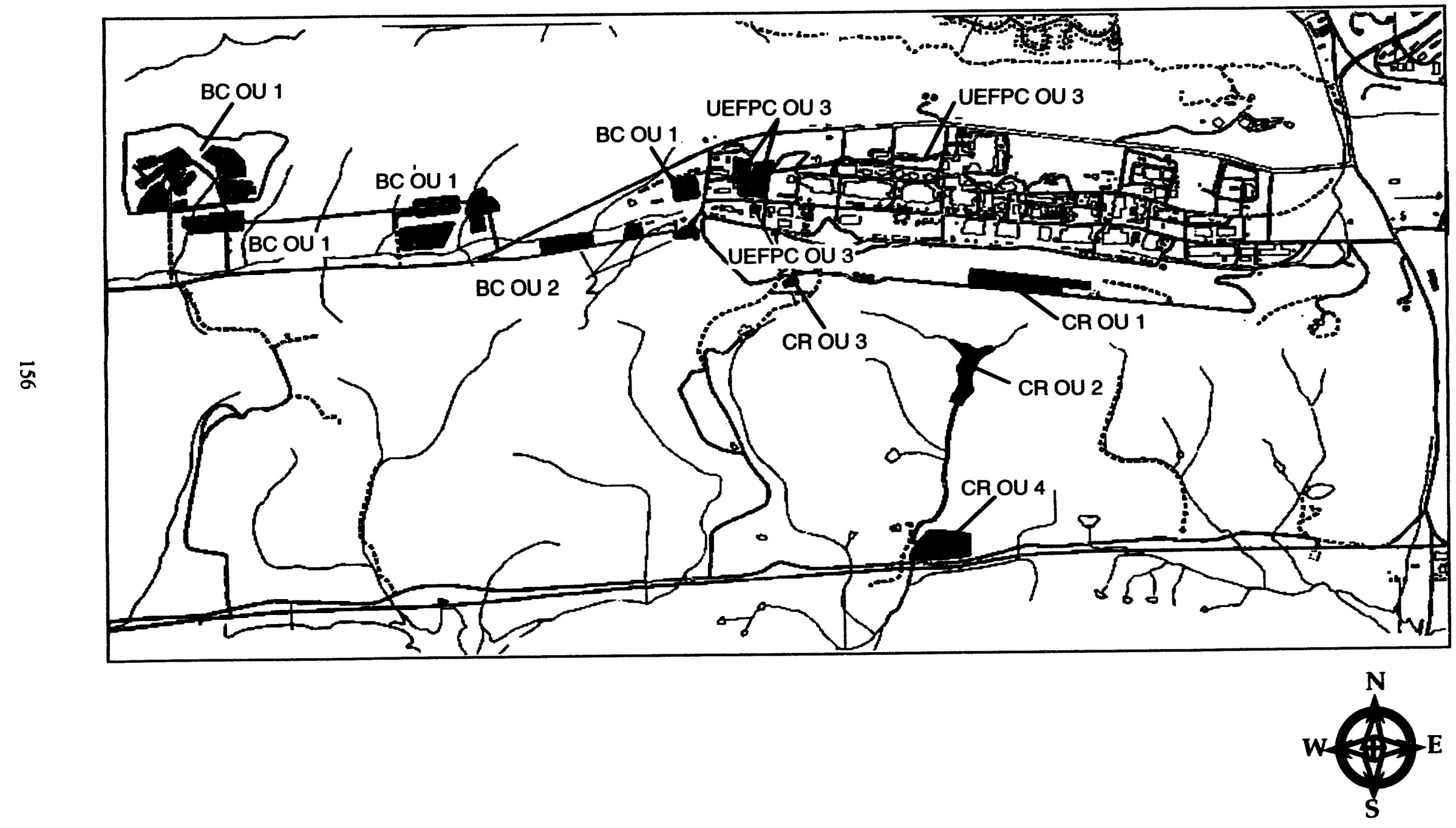




\section{Y-12 Ground water Operable Units}

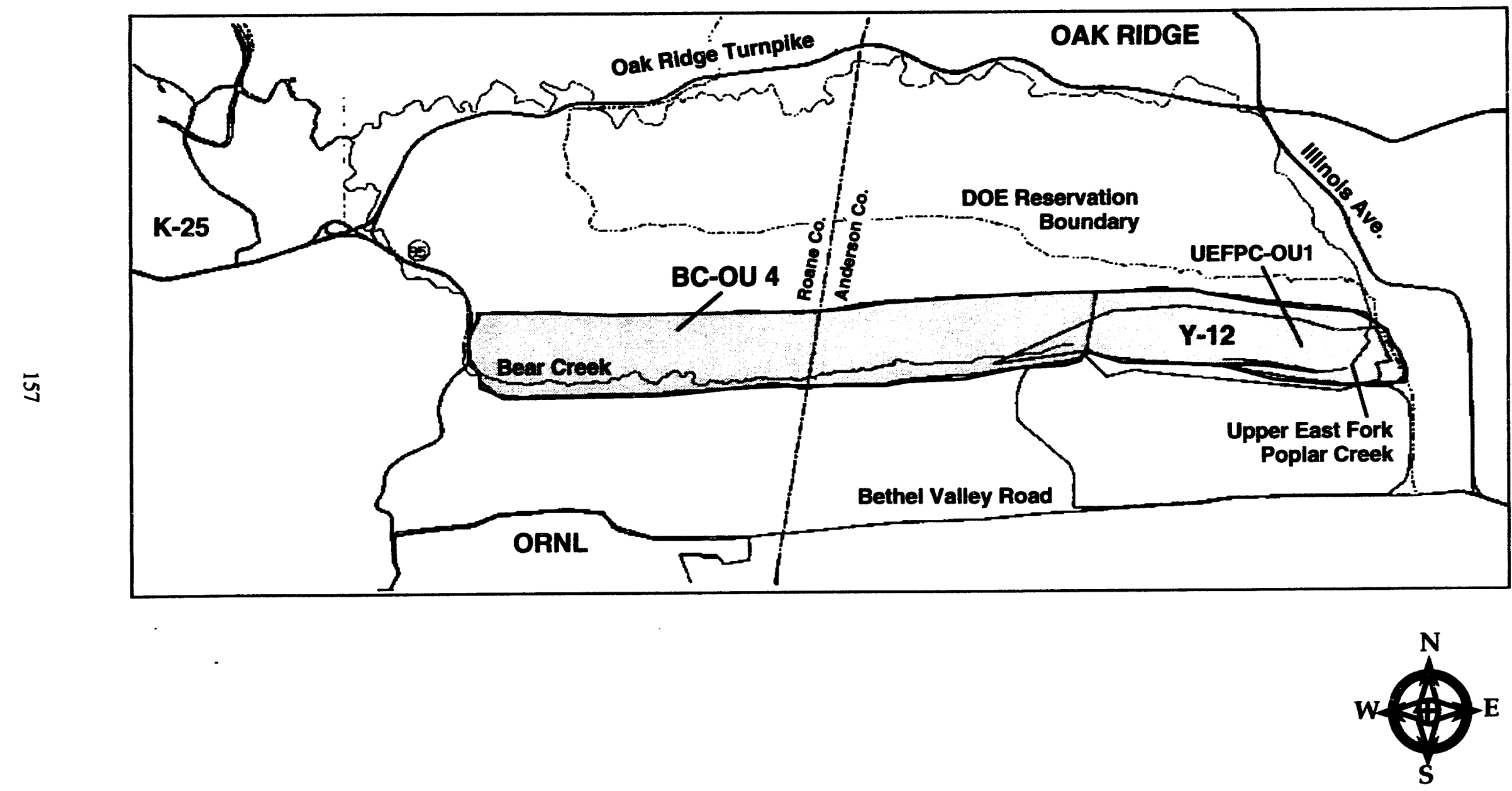



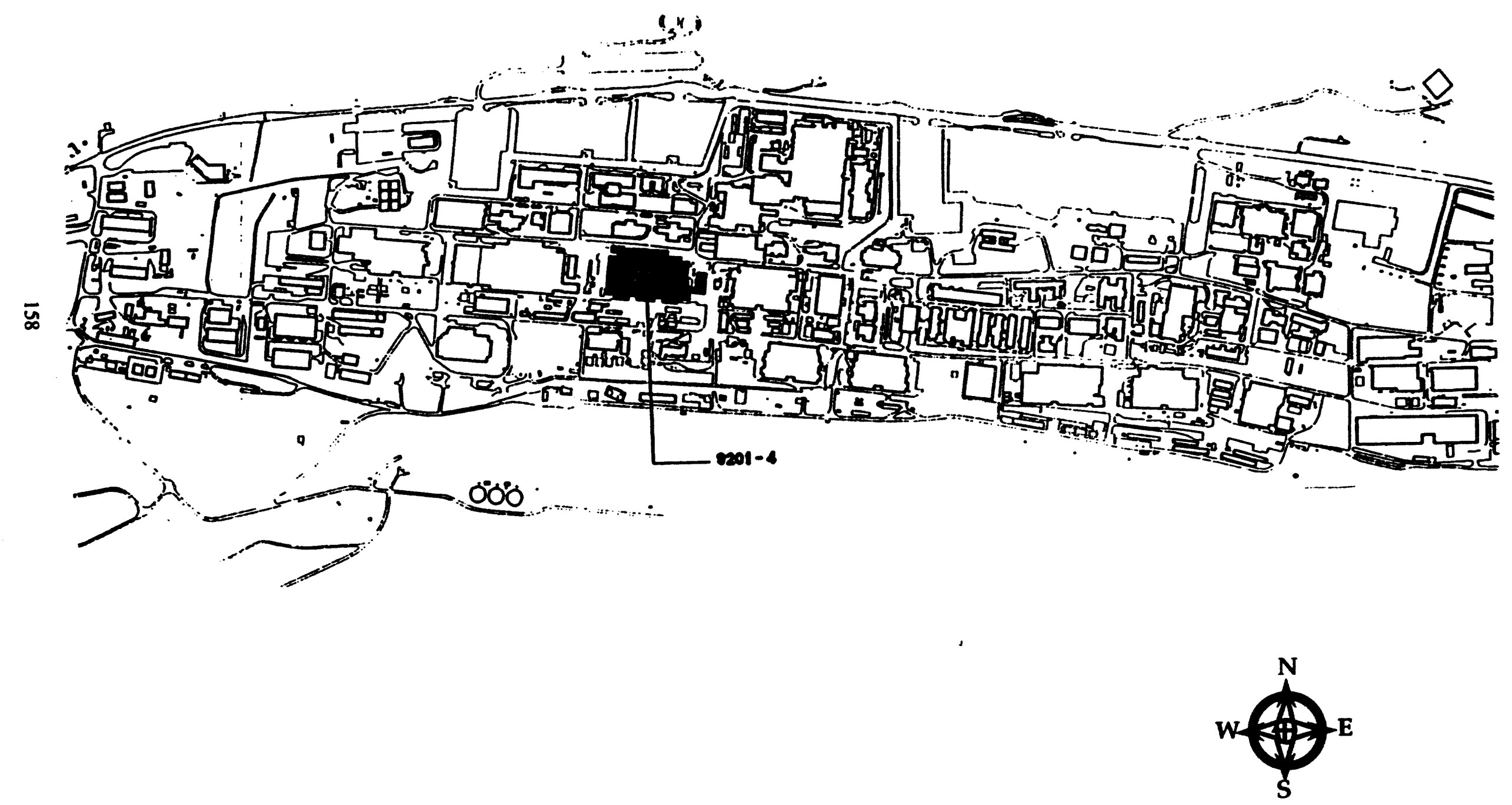


\section{OAK RIDGE OTHER SITES}

\section{ENVIRONMENTAL RESTORATION AND \\ WASTE MANAGEMENT FACILITIES}

\section{DESCRIPTION}

The DOE is currently engaged in evaluation of potentially contaminated sites within the city limits of Oak Ridge, Tennessee, and along the Clinch River. The areas under the Federal Facilities Agreement include the Clinch River/Watts Bar Branch, Lower East Fork Poplar Creek and the Oak Ridge Associated University (ORAU) sites. The ORAU campus is a research facility located in Oak Ridge, Tennessee. Since its establishment in 1945, various research and development activities involving the handling, use, and disposal of hazardous and radioactive materials and wastes have been conducted. As a result, a component of the current Site mission consists of conducting investigations for identification and remediation of environmental contamination stemming from prior activities. The lower East Fork Poplar Creek and Clinch River operable units are on the boundaries of the reservation and are receptors of contaminants transported off the reservation through the groundwater and surface water systems.

\section{AGREEMENTS}

Statute/Type

Agreement-in-Principle

CWA/Compliance Agreement

RCRA Land Disposal

Restrictions/Federal

Facility Compliance

Agreement (FFCA)

Toxic Substances

Control Act/FFCA

Clean Air Act, NESHAPS/

Compliance Agreement

CERCLA/Federal Facility

Agreement
Facilities

ORNL,K-25,Y-12

ORNL

ORNL,K-25,Y-12 DOE/EPA

ORNL,K-25,Y-12 DOE/EPA

ORNL,K-25,Y-12 DOE/EPA

ORNL,K-25,Y-12 DOE/EPA, TN
Completed 2/20/92

\section{Status}

Completed 5/13/91

Completed 2/12/86

Completed 6/12/92

Completed 4/14/92

Completed 1/1/92 


\section{FACILITIES AND PROJECTS}

\section{The Clinch River OU}

The Clinch River/Watts Bar Reservoir OU addresses the transport of water-borne contaminats beyond the Department of Energy Oak Ridge Reservation boundary. The receiving river-reservoir system encompasses 140 river miles in length and 44,000 acres in surface area. Primary areas of investigation are Melton Hill Reservoir, Clinch River, White Oak Creek Embayment, Poplar Creek Embayment and Watts Bar Reservoir. The contaminants of concern include a variety of radionuclides, metals, and organic compounds.

\section{The Freels Bend Area (FBA) OU}

The Freels Bend Area was used to support research conducted at the ORAU South Campus Facilities (SCF). Facilities were used to expose and irradiate test animals that were subsequently observed over a period of time for exposure effects. There are three reported disposal areas for animal carcasses and miscellanous wastes in the FBA. Contaminants of concern include radionuclides, organics, and metals.

\section{The South Campus Facility (SCF) OU}

The South Campus Facility is a research facility originally established in 1945 . SCF areas to be investigated include the wastewater treatment plant, ponds, various laboratories, and animal containment facilities.

Contaminants of concern include radionuclides and Target Compound List and Target Analyst List metals.

\section{The Lower East Fork Poplar Creek (EFPC) OU}

The EFPC extends from the outfall at Lake Reality at the Y-12 Plant boundary downstream to the streams confluence with Poplar Creek. As a result of the loss to the environment of contaminants associated with lithium processing operations at the Y-12 Plant, this OU became contaminated with mercury and trace levels of other metals, organics, and radionuclides. In certain instances, EFPC floodplain soils were used to provide topsoil for 10 miles of sanitary sewer constructed in 1982-83. No records were kept to document the backfill procedures and locations.

\section{The CSX Transportation Group. Inc. (CSX)}

This site is a rail spur which has been used to transport radioactive materials and wastes. The gravel ballast and soil in the railbed are being removed where they are foun . to have become contaminated. The contaminant of concern is ${ }^{137} \mathrm{Cs}$. DOE is currently developing an Engineering Analyst/Cost Assessment which will outline the most appropriate remedial response action. DOE is conducting this project as a voluntary removal action. 


\section{CLINCH RIVER OPERABLE UNIT}
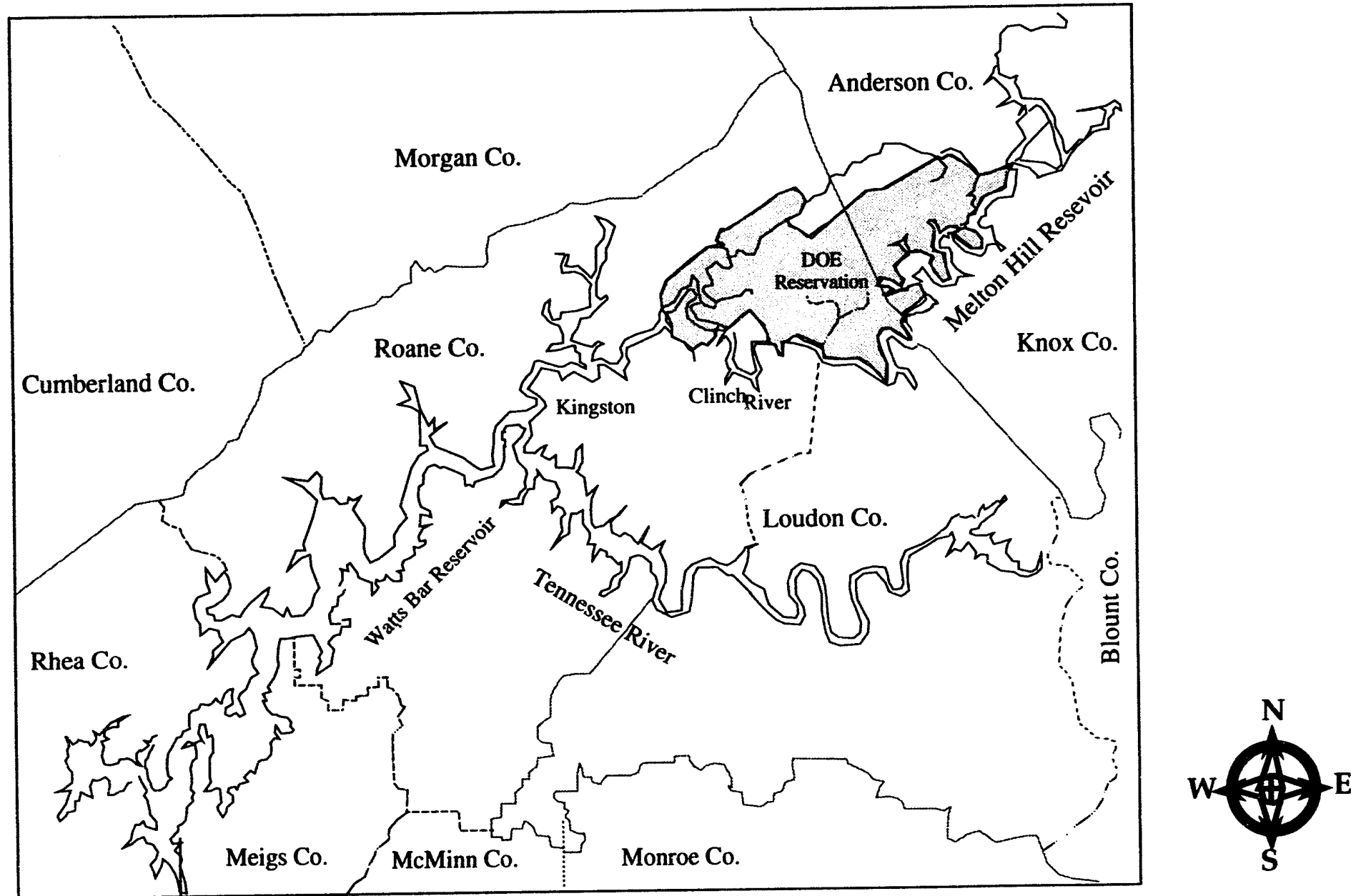
FREELS BEND AREA AND SOUTH CAMPUS FACILITY OPERABLE UNITS
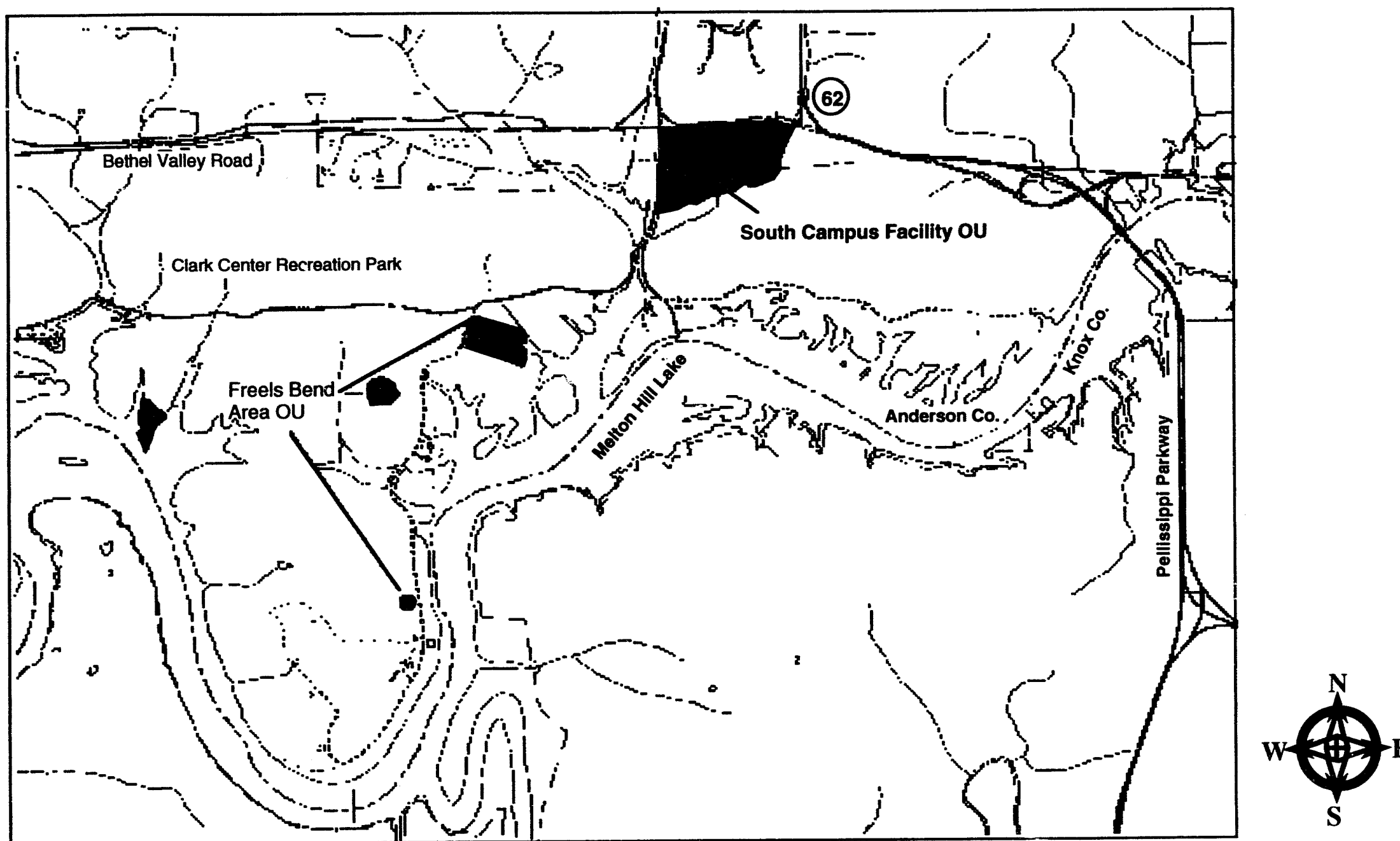
LOWER EAST FORK POPLAR CREEK

AND SEWER LINE BELTWAY OPERABLE UNITS

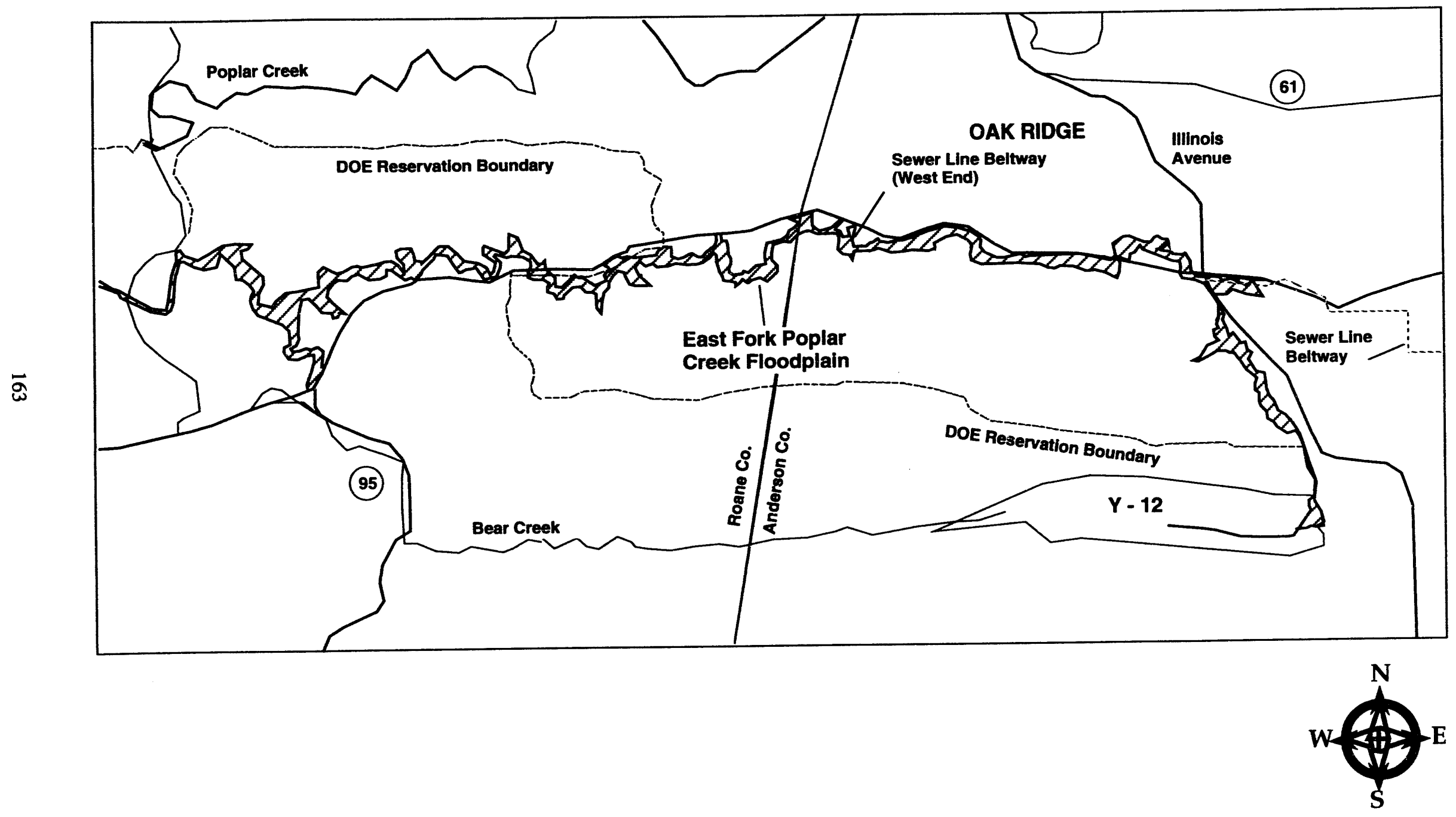




\section{PADUCAH GASEOUS DIFFUSION PLANT}

ENVIRONMENTAL RESTORATION AND

WASTE MANAGEMENT FACILITIES

\section{DESCRIPTION}

The Paducah Gaseous Diffusion Plant (PGDP) occupies approximately 750 acres on a 3422-acre site owned by DOE, located in McCracken County, approximately 10 miles west of Paducah, Kentucky. The primary mission of the site is the separation of uranium isotopes through the gaseous diffusion process. The process produces enriched uranium for use as nuclear fuel for commercial power plants. A significant component of the current site mission consists of conducting investigations for identification and remediation of environmental contamination stemming from prior operations. The site has been divided into 24 Waste Area Groupings (WAGs) which will be addressed in accordance with requirements of the EPA and the State of Kentucky. Existing facilities which are no longer in use are being systematically maintained or scheduled for decontamination and decommissioning. The PGDP has been proposed for listing on the National Priorities List, and negotiations for a Federal Facilities Agreement are now under way. A draft Site Management Plan, which defines the program for remediation of the facility, has been developed and submitted to EPA and Kentucky.

\section{AGREEMENTS}

Statue/Type

Agreement-in-Principle

RCRA Land Disposal

Restriction/Federal

Facility Compliance

Agreement (FFCA)

Administrative Consent Order

CERCLA/Administrative

Consent Order

Toxic Substances

Control Act/FFCA

CERCLA/Federal Facilities

Agreement

HSWA Permit

TSD Permit

Toxic Characteristic Leaching

Procedure/FFCA

DOE/USEC Lease Agreement
Facilities

PGDP

PGDP

PGDP

PGDP

PGDP

PGDP

PGDP

PGDP

PGDP

PGDP
Parties

DOE/KY

DOE/EPA

DOE/EPA

DOE/EPA

DOE/EPA

DOE/EPA/

KY

DOE/EPA

DOE/KY

DOE/EPA

DOE/USEC
Status

Signed 5/13/91

Signed 6/30/92

Signed 11/88

Signed 11/4/88

Signed 1/92

Negotiations under way

Effective 8/19/91

Effective 8/19/91

Signed $4 / 92$

Signed 7/1/93 


\section{FACILITIES AND PROJECTS}

PGDP WAG 1 - consists of five Waste Management Units (WMUs): the KOW burn area, KOW trickling filter and leach field, the C-615 Sewage Treatment Plant, the fire training area, and the trichloroethylene (TCE) spill site. Possible contaminants include TCE, radionuclides, waste oils, and metals.

PGDP WAG 2 - consists of the C-747 contaminated burial ground. Possible contaminants include metals and radionuclides.

PGDP WAG 3 - consists of three WMUs: the C-747-P clean scrap yard, C-746-F classified burial ground, and the C-747-B burial area. Possible contaminants include radionuclides and metals.

PGDP WAG 4 - consists of four underground storage tanks (USTs) which will require investigation under the Kentucky UST Program. Possible contaminants include gasoline and diesel fuel. One of these tanks is currently being closed as a RCRA Hazardous Waste Storage Tank after it was found to contain hazardous wastes.

PGDP WAG 5 - consists of eight WMUs including the C-746-D classified scrap yard, C-375-E5 effluent ditch, C-633 polychlorinated biphenyl (PCB) spill sites, C-632-B sulfuric acid storage tank area, C-531 and 533 switchyards C-633 pumphouse and cooling tower, and the C-745 Kellogg Building site. Possible contaminants include PCBs, chromates, and TCE.

PGDP WAG 6 - consists of six WMUs: C-400 TCE leak site, C-420 PCB spill site, C-400 basement sump, C403 neutralization tank, $\mathrm{UF}_{6}$ cylinder drop test area, and the $\mathrm{C}-400$ technetium storage tank area. Possible contaminants include TCE, PCBs and radionuclides.

PGDP WAG 7 - consists of four C-611 USTs, C-611 diesel/gasoline tank, the C-746-K landfill KOW Toluene Spill Area. Possible contaminants include diesel fuel, gasoline, metals, and volatile organic chemicals (VOCs).

PGDP WAG 8 - contains the C-337-A vaporizers, C-535 and 537 switchyards, and the C-637 pumphouse and cooling tower. Possible contaminants include PBCs and rhromates.

PGDP WAG 9 - is comprised of the C-750-D UST, C-720 compressor pit water storage tank, C-720 underground petroleum naphtha line, and the C-601 diesel spill site. C-722 acid neutralization tank, C-746-H3 Storage Pad, C616-L pipeline and vault, C-720 whiteroom sump, and the C-729 acetylene building drums. Contaminants include radionuclides, PCBs, diesel fuel, gasoline, and other petroleum products.

PGDP WAG 10 - consists of C-410-E hydrofluoric acid (HF) holding pond, C-634-B sulfuric acid storage tank, C-637 pumphouse and cooling tower, and PCB contaminated soil. Possible contaminants include PCBs, chromates, and HF.

PGDP WAG 11 - consists of the C-410.B HF neutralization lagoon, C-410-C neutralization tank, C-405 incinerator, the $\mathrm{C}-635$ pumphouse and cooling tower, and the residential/inert landfill borrow area. Possible contaminants include radionuclides, chromates, and metals.

PGDP WAG 12 - includes the C616-F Full flow lagoon, C-616-E sludge lagoon, and the C-616 chromates reduction facility. Possible contaminants include PCBs and chromates.

PGDP WAG 13 - encompasses the C-611-W sludge lagoon, C-611-Y overflow lagoon, C-611-V lagoon,C-611-4 lagoon and the $\mathrm{C}-100$ berm. Possible contaminants include PCB and radionuclides. 
PGDP WAG 14 - consists of C-400 to C-404 underground transfer line which is possibly contaminated with TCE and radionuclides.

PGDP WAG 15 - contains the C-712 acid neutralization lagoon, C-746-A inactive PCB transformer area, and the C-746-A1 and C-746-A2 USTs. Possible contaminants include PCB, gasoline, and diesel fuel.

PGDP WAG 16 - is the C-333-A vaporizer, C-333 PCB soil contamination, and C-410-E HF vent surge tank. Possible contaminants include PCB, gasoline, and diesel fuel.

PGDP WAG 17 - encompasses rubble piles possibly contaminated with radionuclides.

PGDP WAG 18 - is the plant storm sewer system. Possible contaminants include PCB, TCE, and radionuclides.

PGDP WAG 19 - consists of PCB soil contamination at C-331, C-310, C-333, C-745, C-743-T01, C-617-A, C304, Ditch 017 flume. Possible contaminants are PCBs.

PGDP WAG 20 - consists of the C-100 trailer complex soil contamination and the C-726 sand blasting facility. Radionuclides are the possible contaminants.

PGDP WAG 21 - consists of the chilled water system leak site. Chromates are the possible contaminants.

PGDP WAG 22 - consists of the C-749 uranium burial ground, C-747-A burial ground and the C-747-A burn area. Radionuclides and PCB are the contaminants of concern.

PGDP WAG 23 - consists of four PCB spill sites, two PCB staging areas, C-728 motor cleaning facility, C-728 clean waste oil tank, and C-747-C oil land farm. Possible contaminants include PCBs, waste oil, and TCE.

PGDP WAG 24 - consists of the C-747-A UF 4 drum yard, C-74\%-E contaminated scrap yard, and C-746-C scrap yard. Possible contaminants are metals.

PGDP WAG 25 - consists of Little Bayou Creek and Big Bayou Creek. Possible contaminants include metals, PCBs, and radionuclides.

\section{DECONTAMINATION AND DECOMMISSIONING FACILITIES}

The C-340 Metals Plant complex was used for the reduction of UF to $U_{6}$ and for the reduction of $U_{4}$ to uranium metal. Transfer to the program was effective in FY 1991. The complex includes the C-340-A Powder Building, the C-340-B Metals Building, the C-340-C Slag Building and the C-340-D Magnesium Storage Building, the C-342 Ammonia Dissociator, and the C-342-A Ammonia Dissociator Addition.

The $\mathbf{C}-410$ Feed Plant Complex was used for $\mathrm{UF}_{6}$ feed production. It was placed in standby in 1977 and was transferred to the program curing FY 1991. The Feed Plant consists of three major facilities as follows:

C-410 complex- The C-410 complex includes the C-410 Feed Plant, C-410-C HF Acid Neutralization Building, C-410-D Fluorine Storage Building, the C-410-F HF Acid Storage Building, the C-410-G HF Acid Storage Building, the C-410-H HF Acid Storage Building, the C-410-I Ash Receiver Shelter, and the C-410J HF Acid Storage Building.

C-411 Cell Maintenance Building

C-420 Greensalt Plant 


\section{PADUCAH GASEOUS DIFFUSION PLANT \\ WASTE AREA GROUPINGS (1-16)}

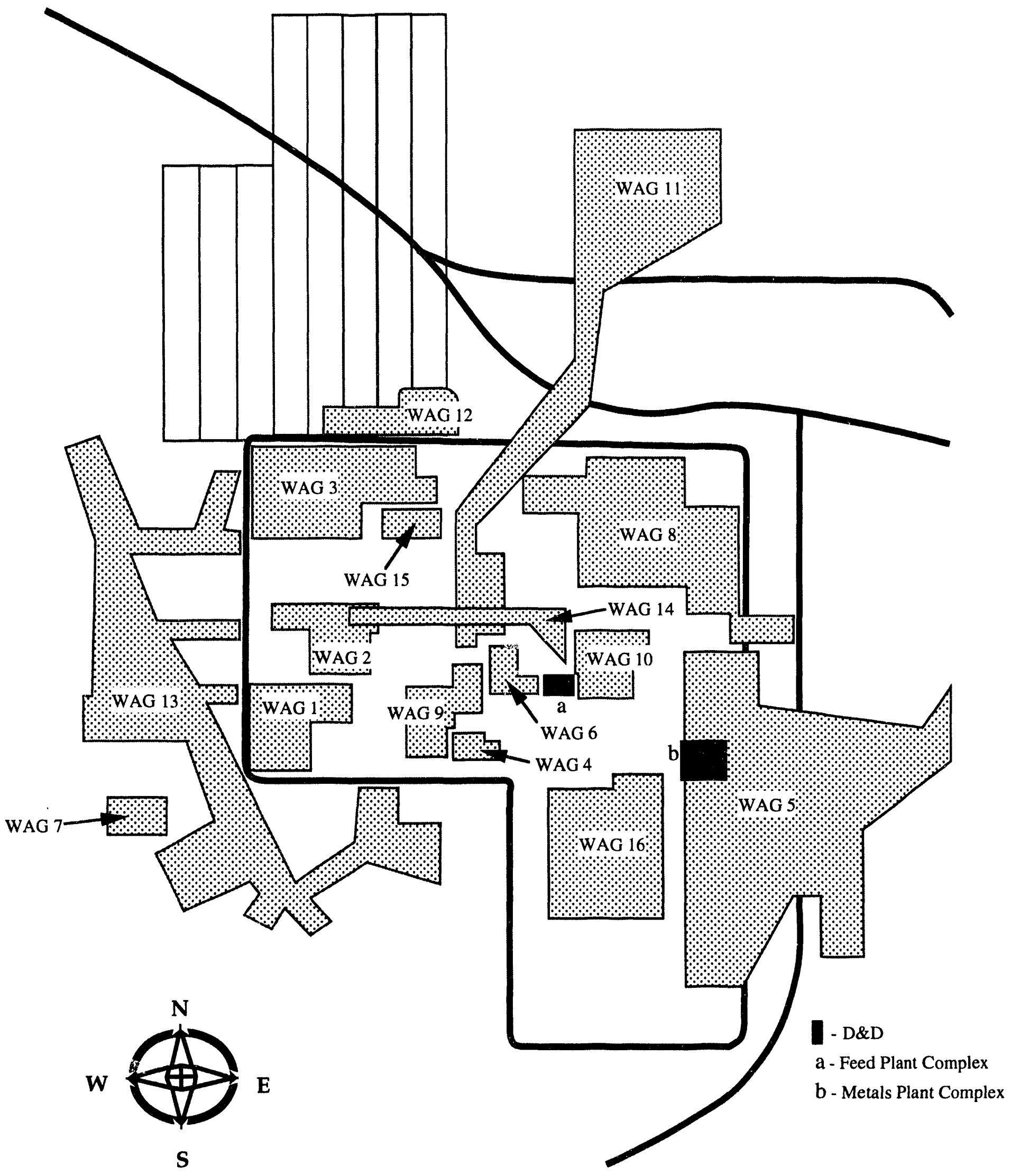




\section{PADUCAH GASEOUS DIFFUSION PLANT \\ WASTE AREA GROUPINGS (20-24)}

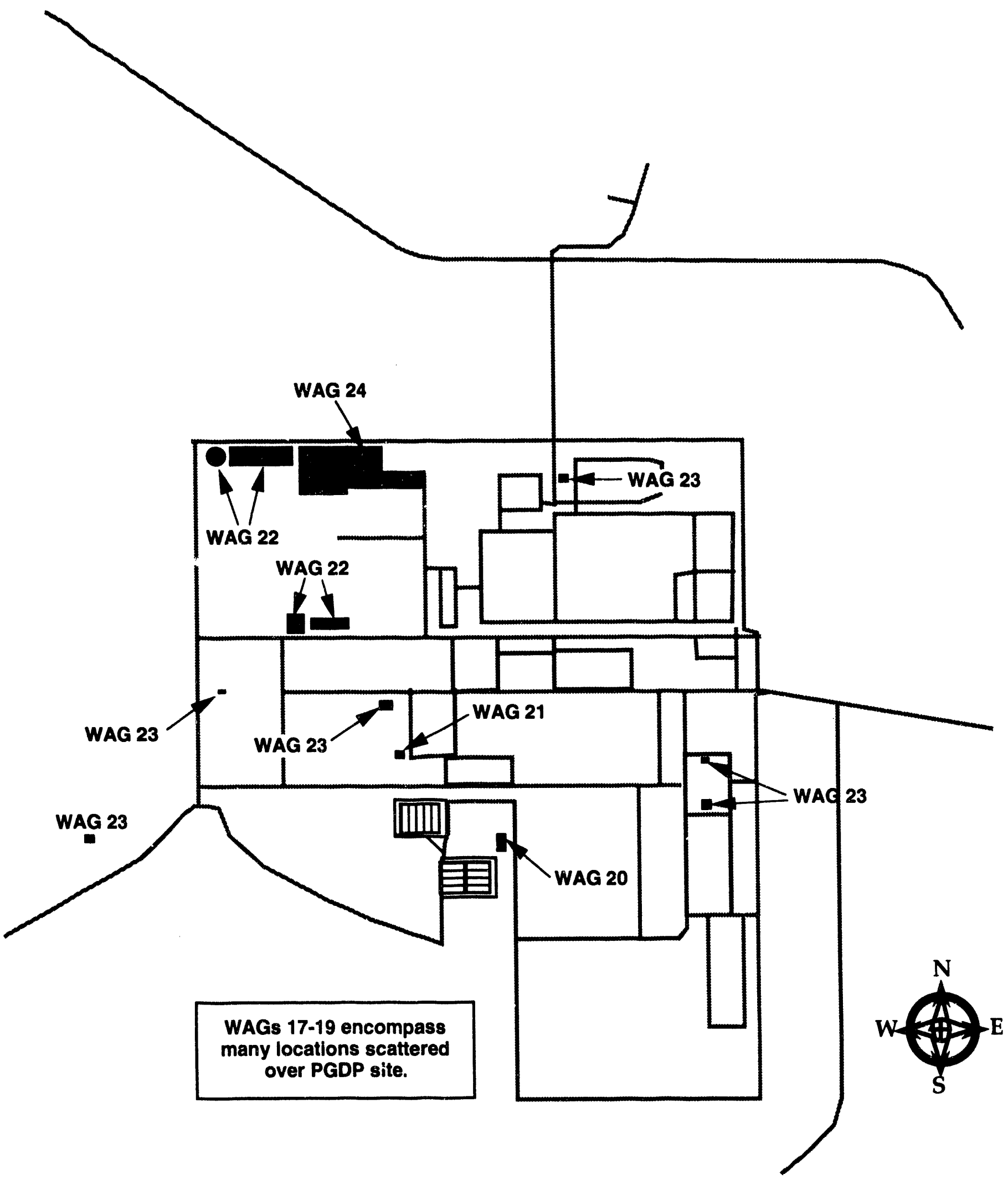




\section{PORTSMOUTH GASEOUS DIFFUSION PLANT}

\section{ENVIRONMENTAL RESTORATION AND \\ WASTE MANAGEMENT FACILITIES}

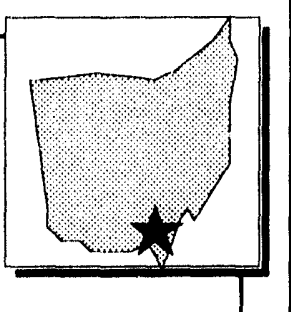

\section{DESCRIPTION}

The Portsmouth Gaseous Diffusion Plant is located in a DOE owned reservation of about 3700 acres in Pike County, approximately 20 miles north of Portsmouth and 70 miles south of Columbus, $\mathrm{OH}$. The principal mission at the Portsmouth Site is the separation of uranium isotopes by gaseous diffusion. This process produces enriched uranium which is used as fuel for commercial power plants and for military purposes. A significant component of the current site mission consists of conducting investigations for identification and remediation of environmental contamination stemming from prior operations. The site is subject to RCRA requirements outlined in an existing Administrative Order by consent with the EPA, and Consent Decree with the State of Ohio. Existing facilities which are no longer in use are being systematically maintained or scheduled for decontamination and decommissioning.

\section{AGREEMENTS}

$\begin{array}{llll}\text { Statue/Type } & \text { Facilities } & \text { Parties } & \text { Status } \\ \text { Consent Decree } & \text { Portsmouth } & \text { DOE/OEPA } & 8 / 13 / 89 \\ \begin{array}{l}\text { Administrative Order } \\ \text { By Consent }\end{array} & \text { Portsmouth } & \text { DOE/USEPA } & 11 / 1 / 89 \\ \begin{array}{l}\text { OEPA Director's } \\ \text { Findings and Orders }\end{array} & \text { Portsmouth } & \text { DOE/OEPA } & 7 / 15 / 91 \\ \text { Agreement-In-Principle } & \text { Portsmouth } & \text { DOE/OEPA } & \text { Under Negotiation } \\ \text { Lease } & \text { GDP Operations } & \text { DOE/USEC } & \text { Effective } 7 / 1 / 93\end{array}$

\section{FACILITIES AND PROJECTS}

The Northeast Oil Biodegradation Plot (NEOBP) consists of a section of land used for the disposal of lubricating oils contaminated with PCB, uranium, and technetium.

The Firing Ranges and Old Firing Ranges (X114 and X114A) constitute three SWMUs, and are areas that are used for small arms practice ranges. The soil has been contaminated with lead.

The Old Training Facility (OTF) was used for welding and metal working training. The soil in the SWMU is suspected of containing TCE contamination. 
The South Holding Pond Waste Pile (SHPWP) contains spoils dredged from the bottom of the South Holding Pond. Contaminants of concern include uranium, TCE, and PCB.

The West Construction Spoils Area (WCSA) consists of debris resulting from plant construction. The area is currently under investigation, but the possible contaminants include used lubricating oils and hydraulic fluids.

The Oil Biogradation Plots (X-231A and X-231B) were used for the disposal of used lubricating oils ladened with PCB, uranium TCE, and technetium.

The Lime Sludge Lagoon (X-611A) was previously used for clarification of treated recirculating cooling water. The primary contaminant of concern is chromium.

The Old Sewage Treatment Plant $(X-615)$ is an abandoned sewage treatment facility believed to be contaminated with radionuclides, oils, PCB, and TCE.

The Chromium Sludge Lagoon (X-616) has been closed under RCRA, but was previously used for clarification of treated recirculating cooling water. The primary contaminant of concern is chromium.

The RCRA/Uranium Tank Storage Area (X-700) has been used for the storage of mixed wastes. Contaminants of concern include TCE, uranium, and technetium.

The Neutralization Pit (X-701CP) was used in the $\mathrm{pH}$ adjustment of waste metal working fluids prior to discharge. Contaminants of concern include uranium, technetium, and TCE.

The Incinerator (X-705A) was used to burn low level radioactive waste such as paper, boot covers, and protective clothing. Radionuclides constitute the primary suspect contaminants. Has not been in operation for over five years.

The Radioactive Waste Pit and Acid Pit (X-710) received radioactive waste and acidic waste for neutralization from laboratory facilities. They are suspected of being contaminated with TCE, uranium, and radionuclides.

The Old Sanitary Landfill (X-734) was used for disposal of non-radioactive wastes. Identification of contaminants will be made during the RCRA Facility Investigation.

The Construction Spoils Areas (X-734A and X-734B) were used for the disposal of construction debris during plant construction. Suspected contaminants include used lubricating oils and hydraulic fluids.

Landfill Cells 1 through 6,15 and 16 (X-735) constitute a SWMU. Cells 1 through 6 are considered RCRA units for closure due to the presence of hazardous wastes including solvents. Cells 15 and 16 are asbestos disposal sites, and are to be closed as part of the X735 Sanitary Landfill closure.

The Waste Oil Storage Facility and Hazardous Waste Tank (X-740) are used to store waste oils suspected of contamination with PCB and radionuclides. In June 1993, facility was undergoing closure when "unexpected event" halted work. OEPA granted extension to develop revised closure concept and plan.

The Outside Low-Level Waste Storage Area (X-744Y) is a container storage lot for low-level wastes. Identification of contaminants is on-going.

The Scrap Metal Yard (X-747F) is a storage yard for scrap metals suspected of uranium and technetium contamination. 
The Contaminated Material Disposal Area (X-749) is a landfill used for the disposal of low-level wastes possibly contaminated with uranium, technetium, radionuclides, and TCE.

The Classified Materials Disposal Area (X-749A) is a landfill used for disposal of classified wastes.

Identification of contaminants is on-going. Closure is in process.

The Hazardous Waste Tank $(\mathbf{X}-\mathbf{7 5 0})$ receives used engine lubricating oils from the garage facility. Closure of the tank was completed in July 1993.

The Underground Storage Tank (X-751) is a fuel storage tank.

The Waste Storage Facility (X-752) is used for the storage of RCRA waste materials. Soils associated with this facility are also under investigation. Contractor completed all closure activities required for clean closure on June $25,1993$.

The Neutralization Pit (X-760) is used for the adjustment of the $\mathrm{pH}$ of effluents from the pilot facility. Contaminants of concern include uranium.

The R/A Building Centrifuge Equipment (X-7725) consists of radioactively contaminated equipment used in the uranium enrichment process. Facility is now permitted for storage of RCRA wastes.

\section{Decontamination and Decommissioning Facilities}

Six facilities associated with the terminated Gaseous Centrifuge Enrichment Plant (GCEP) were transferred to the program in FY 1991. The GCEP was a plant intended to enrich uranium (as UF $)$ in the $U^{235}$ isotope for use as fuel in commercial power plants. The plant was operated for a short time in 1985.

X-7727H Transfer Corridor

X-1007-AV Southeast Portal

X-2307-F Feed \& Withdrawal Portal

X-3001 Process Building

X-3012 Process Support Building

X-3344 Feed \& Withdrawal Building

There are two Surplus Gaseous Diffusion Plant Facilities in the D\&D program which are planned to be demolished.

The High Assay Sampling Area(HASA) within X-326 Building. Facility w'll be phased out with HEU shutdown.

The X-705-A Incinerator

Other Facilities

The X-623 and X-624 Groundwater Treatment Buildings

Used to maintain ERWM activities. 


\section{PORTSMOUTH GASEOUS DIFFUSION PLANT SOLID WASTE MANAGEMENT UNITS}

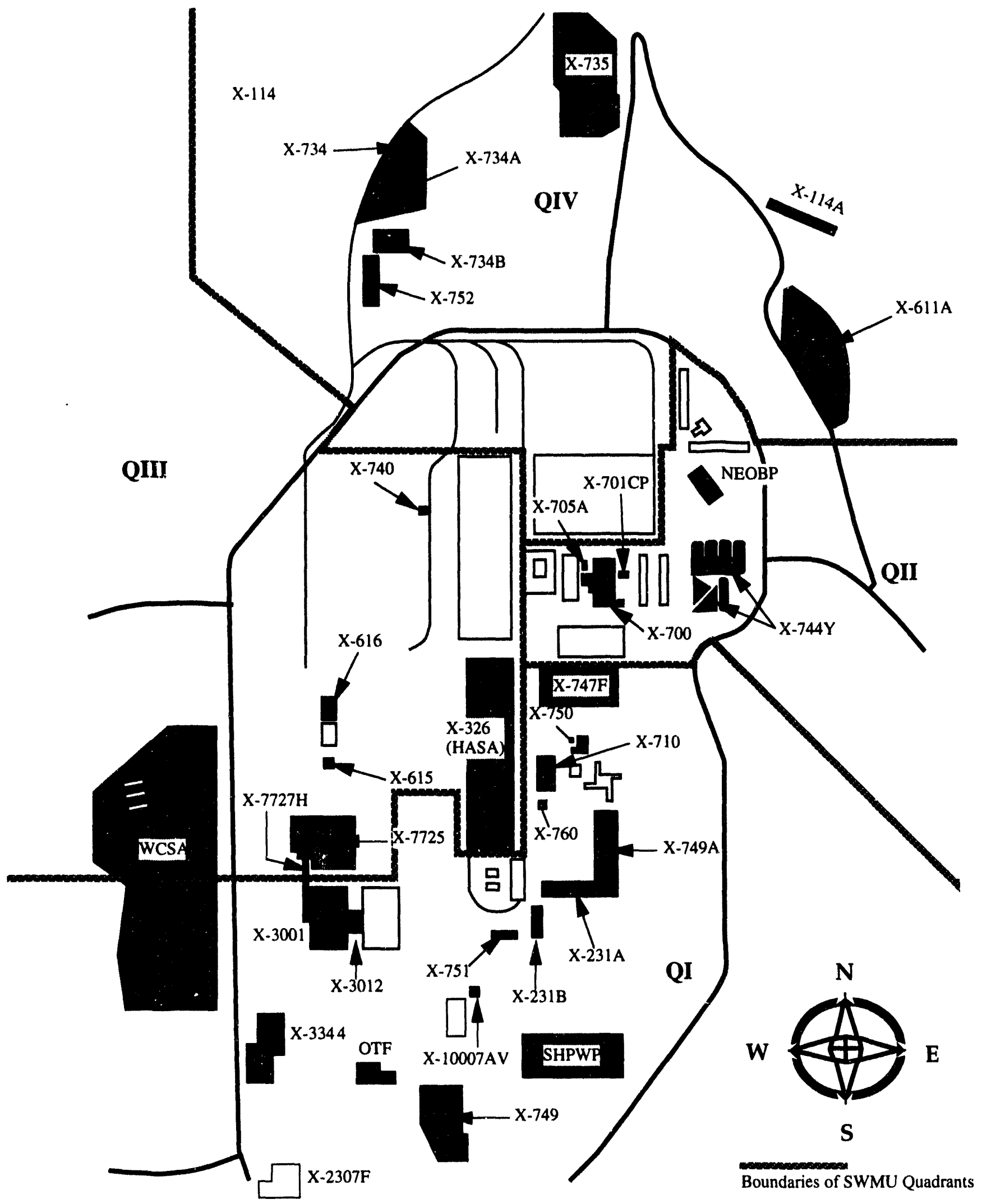




\section{WELDON SPRING SITE REMEDIAL ACTION PROJECT \\ ENVIRONMENTAL RESTORATION AND \\ WASTE MANAGEMENT FACILITIES}

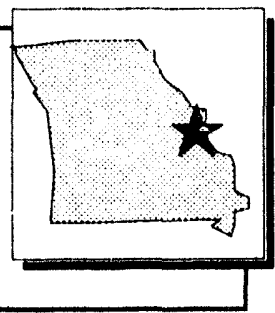

\section{DESCRIPTION}

The Weldon Spring Site, a 229-acre site located about 30 miles west of St. Louis, Missouri, was used by the Army as an ordnance works in the 1940s. In the 1950s and 1960s, the Atomic Energy Commission used Weldon Spring for processing uranium and thorium. The site is on the EPA National Priorities List, and DOE is conducting a comprehensive remedial action program, including long-term management of radiological wastes.

\section{AGREEMENTS}

\section{Statue/Type}

CERCLA/

Federal Facility

Agreement

\section{CERCLA/}

National Environmental

Policy Act

Memorandum

of Understanding

\section{Facilities}

Weldon Spring Site

Weldon Spring Site

DOE/EPA

Completed 8/22/86

Chemical Plant

DOE/Army

\section{Status}

Completed 1/28/92

DOE/EPA

\section{FACILITIES AND PROJECTS}

Conduct remedial actions at the following four areas:

Quarry - nine-acre site containing 126,630 cubic yards of radiologically contaminated soil and rubble and three million gallons of radiologically and chemically contaminated surface water.

Chemical Plant - Forty-four buildings and other structures to be dismantled with 392,129 cubic yards of contaminated soil and building material to be disposed of. This area includes the North and South Dumps, Frog Pond, Ash Pond, a coal storage area, and a spoils pile; all requiring remediation.

Rafrinate Pits - four waste lagoons, containing 407,930 cubic yards of raffinate sludges/soil and 57 million gallons of radiologically or chemically contaminated water.

Vicinity Properties - 125,250 cubic yards of contaminated soil. 


\section{WELDON SPRING SITE REMEDIAL ACTION PROJECT}

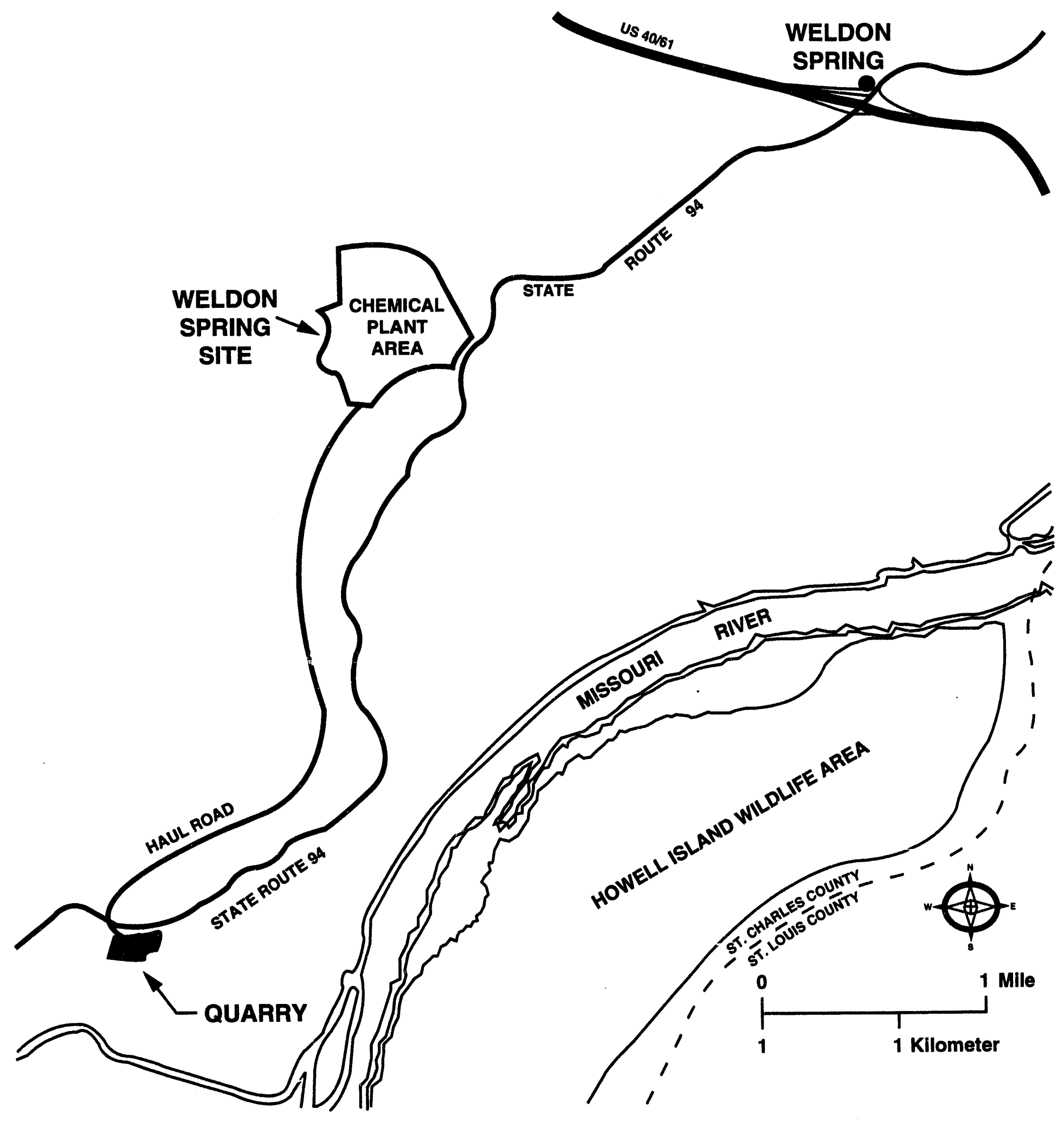




\section{WELDON SPRING SITE REMEDIAL ACTION PROJECT}

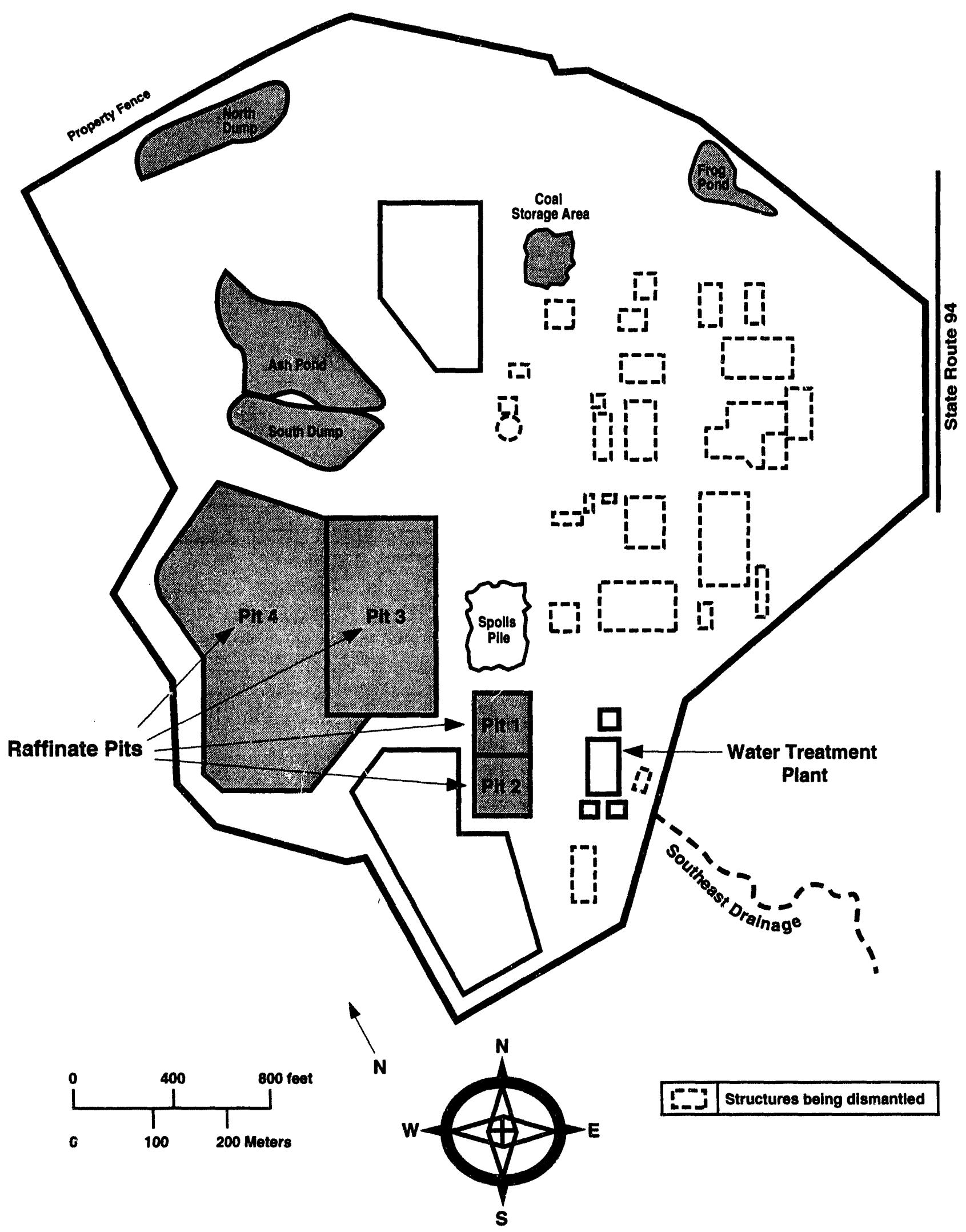




\section{HANFORD SITE}

\section{ENVIRONMENTAL RESTORATION AND WASTE MANAGEMENT FACILITIES}

\section{DESCRIPTION}

The Hanford Site covers approximately 560 square miles of semiarid land along the Columbia River in Benton, Franklin, and Grant Counties in the south-central portion of the state of Washington. The city of Richland, Washington, located at the southeastern corner of the site, is the nearest population center.

The Hanford Site is owned by the U.S. Government and managed by the U.S. Department of Energy, Richland Operations Office (RL). In early 1943, the U.S. Army Corps of Engineers selected the Hanford Site as the location for reactor, chemical separation, and related activities for the production and purification of special nuclear materials and other nuclear activities. The mission of the Hanford Site recently has focused on environmental remediation and restoration. In 1990, the site was turned over to the Office of Environmental Restoration and Waste Management (EM). Currently, only a small portion of the site facilities are not assigned to EM.

Activities on the Hanford Site are centralized in numerically designated areas. The reactors are located along the Columbia River in the northern portion of the site, in the 100 Areas. These include the Surplus Defense Production Reactor Areas 100-B/C, 100-D/DR, 100-F, 100-H, 100-K and 100-N. The reactor fuel reprocessing units are located in the 200 Areas, which are on a plateau that is approximately 7 miles south and west of the Columbia River. This portion of the site contains the irradiated uranium fuels processing and plutonium separation facilities and the major radioactive waste storage and disposal facilities. The 300 Area, located adjacent to and north of the city of Richland, Washington, contains the reactor fuel manufacturing plants and research and development laboratories. In this area, Westinghouse Hanford Company (Westinghouse Hanford) operates a fuel production facility, and Pacific Northwest Laboratory (PNL) and Westinghouse Hanford operate research laboratories. Siemens, the Kaiser Engineers Hanford Company's minor construction services facilities, and the Hanford Site transportation and stores services are located between the city of Richland and the 300 Area. The 400 Area, located in the southeastern part of the site, approximately 5 miles northwest of the 300 Area and southwest of the Washington Public Power Supply System (WPPSS), contains the Fast Flux Test Facility and the Fuels and Materials Examination Facility, which are used for testing liquid metal reactor systems. The 600 Area covers all locations not specifically given an area designation. Administrative offices are located in the 700 Area, which is in downtown Richland. Adjacent to and north of Richland, the 1100 Area contains offices and shops associated with administration, maintenance, transportation, and materials procurement and distribution. The 3000 Area, between the 1100 Area and 300 Area, contains engineering offices, administrative offices, and construction services facilities.

The waste units at the Hanford Site are grouped into four aggregate areas $(100,200,300$, and 1100) that reflect the Hanford Site listings on the National Priorities Listing (NPL). These aggregate areas are further divided into operable units containing individual waste management units that have similar characteristics and are located within the same general geographical area. Of 1494 waste management units operated by EM Programs, 1,249 are assigned to source operable units for subsequent investigation and 1 -mediation under the Environmental Restoration Remedial Action Program (ERRA). In addition, there are nine groundwater operable units: five beneath the 100 , two beneath the 200 , and one beneath the 300 and 1100 aggregate areas. The remaining waste management units are surplus facilities (123) and active RCRA units (122). 


\section{AGREEMENTS}

$\begin{array}{llll}\text { Statute/Type } & \text { Facilities } & \text { Parties } & \text { Status } \\ \text { Hanford Federal Facility } & \text { Hanford Site } & \text { DOE/EPA/WA } & \text { Completed 5/15/91 } \\ \begin{array}{l}\text { Agreement and Consent } \\ \text { Order }\end{array} & & & \end{array}$

\section{FACILITIES AND PROJECTS}

100 Areas - Between 1943 and 1962, nine water-cooled, graphite-moderated plutonium production reactors were constructed and operated within the 100 Areas along the shore of the Columbia River, upstream from the now-abandoned town of Hanford. Eight of these reactors (B, C, D, DR, F, H, KE, and KW) have been retired from service and are under evaluation for decommissioning. The ninth reactor, the $\mathrm{N}$ Reactor, was recently taken out of standby status and will be retired. In some of the reactor areas, after the reactor was retired from service, the ancillary facilities were used as laboratories for special studies or for storage or treatment purposes.

100-B/C Area - The 100-B/C Area is located in Benton County along the southern shoreline of the Columbia River in the north-central part of the Hanford Site, approximately 28 miles northwest of the city of Richland, Washington. It contains the facilities associated with the operation of the $\mathrm{B}$ and $\mathrm{C}$ plutonium production reactors, and it encompasses an area of approximately 1.2 miles. For purposes of environmental restoration, this area is divided into four source operable units (100-BC-1, 100-BC-2, 100-BC-3, and 100-BC-4) and one groundwater operable unit (100-BC-5).

100-D/DR Area - The 100-D/DR Area is located in Benton County along the southern shoreline of the Columbia River in the north-central part of the Hanford Site, approximately 31 miles north-northwest of the city of Richland, Washington. It contains the facilities associated with the operation of the D and DR plutonium production reactors, and it encompasses an area of approximately 1.2 square miles. For purposes of environmental restoration, this area is divided into three source operable units (100-DR-1, 100-DR-2, and 100-DR-3) and is part of groundwater operable unit 100-HR-3.

100-F Area - The 100-F Area is located in Benton County along the southern shoreline of the Columbia River in the north-central part of the Hanford Site, approximately 20 miles northwest of the city of Richland, Washington. It contains the facilities associated with the operation of the F plutonium production reactor, and it encompasses an area of approximately 1.1 square miles. For purposes of environmental restoration, this area is divided into two source operable units (100-FR-1 and 100-FR-2) and one groundwater operable unit (100-FR-3).

100-H Area - The 100-H Area is located in Benton County along the southern shoreline of the Columbia River in the north-central part of the Hanford Site, approximately 27 miles north-northwest of the city of Richland, Washington. It contains the facilities associated with the operation of the $\mathrm{H}$ plutonium production reactor, and it encompasses an area of approximately 0.9 square miles. For purposes of environmental restoration, this area is divided into two source operable units (100-HR-1 and 100-HR-2) and one groundwater operable unit (100-HR-3).

100-K Area - The i $w$-K Area is located in Benton County along the southern shoreline of the Columbia River in the north-central part of the Hanford Site, approximately 25 miles northwest of the city of Richland, Washington. It contains the facilities associated with the operation of the $\mathrm{KW}$ and $\mathrm{KE}$ plutonium production reactors, and it encompasses an area of approximately 1.2 square miles. For purposes of environmental restoration, this area is divided into three source operable units (100-KR-1, 100-KR-2, and 100-KR-3) and one groundwater operable unit (100-KR-4). 
100-N Area - The 100-N Area is located in Benton County along the southern shoreline of the Columbia River in the north-central part of the Hanford Site, approximately 30 miles northwest of the city of Richland, Washington. The $\mathrm{N}$ reactor was the last reactor to be constructed as a major production reactor at the Hanford Site. It differs from the other reactors at Hanford in that it was designated as a dual purpose reactor capable of producing special nuclear materials and steam. The 100-N Area encompasses an area of approximately 0.6 square miles. For purposes of environmental restoration, this area is divided into one source operable unit (100-NR-1) and one groundwater operable unit (100-NR-2).

200 West Aggregate Area - The 200 West Area is a controlled area of approximately 3.2 square miles near the middle of the Hanford Site wherein operations related mainly to nuclear fuel separation are located. This area consists of four main spent fuel processing areas: S Plant and T Plant, where processing to separate uranium and plutonium from irradiated fuel rods took place; U Plant, where "ranium recovery operations took place; and Z Plant where plutonium separation and recovery operations took place. For purposes of environmental restoration, this area is divided into 17 source operable units grouped into 5 aggregate areas and one aggregate area groundwater operable unit.

The 200 West Aggregate Area also contains nonradioactive support facilities, including transportation maintenance buildings, service stations, and a coal-fired powerhouse for process steam production, steam transmission lines, raw water treatment plants, water storage tanks, electrical maintenance facilities, general support facilities such as shops, offices and warehouses, and subsurface sewage disposal systems. In addition to these facilities, other major facilities include the laundry, evaporator, and central waste complex.

Large portions of the 200 West Aggregate Area consist of burial sites, including caissons and various types of burial trenches, which were used for disposal of solid wastes.

Major facilities in the 200 West Aggregate Area:

S Plant - The reduction-oxidation (REDOX) or S Plant (202-S) was constructed between May 1950 and August 1951 and was used to separate plutonium and uranium from irradiated fuel rods until July 1967. The associated analytical laboratory (222-S) continues to operate, supporting the B Plant operations and performing research and development in support of waste management and environmental restoration operations. It also serves as a backup to the PUREX and Z Plant analytical laboratories. The S Plant Aggregate Area includes 27 single-shell tanks and 3 double-shell tanks. The 241-S Tank Farm houses 12 single-shell tanks, and the 241-SX Tank Farm houses 15 single-shell tanks. Double-shell tanks are part of the 241-SY Tank Farm. Six ponds and one solid waste burial ground exist within the S Plant Aggregate Arta.

T Plant - The T Plant was constructed in 1944 and operated as one of the first separations facilities completed at the Hanford Site. The 221-T Building (also known as the T Plant or T Canyon Building) housed the first operational, full-scale, bismuth phosphate separations facility in the world. Separation operations in the 221-T and 224-T Buildings ceased in 1956.

The 221-T Building, presently referred to as the Containment Systems Testing Facility (CSTFO), was used for a series of testing programs from 1964 to 1990. These programs were managed by Pacific Northwest Laboratory (PNL) from 1964 to 1969 and by Westinghouse Hanford from 1976 to 1990 . Currently, operations in the 221-T Building include service in radioactive decontamination, reclamation, and decommissioning process equipment.

The 224-T Building was used to store plutonium scrap in liquid and solid forms beginning in the early 1970's. The scrap was removed from the 224-T Building in 1985 (although the building was not decontaminated) when it was officially designated the Transuranic Waste Storage and Assay Facility (TRUSAF). The sealed canyon, an old sealed processing hood, and all the piping associated with the 
plutonium separation processing, remain entombed in the building. The TRUSAF operation consists of nondestructive assay and nondestructive examination of newly generated contact-handled transuranic (TRU) solid waste packages for general compliance with the Waste Isolation Pilot Plant Waste Acceptance Criteria requirements.

The T Plant Aggregate Area includes three tank farms which comprise a total of 40 single-shell tanks, as well as three (3) ponds and two (2) burial sites.

U Plant - The U Plant was constructed in 1944 as one of the three original chemical separation plants (B, T, and U Plants) to support plutonium production during World War II. The plants were built to extract plutonium from fuel rods irradiated in the Hanford production reactors. However, U Plant was never used for that purpose because B Plant and T Plant were sufficient to meet plutonium production needs. The U Plant was used to train B and T Plant operators until 1952.

The primary U Plant building went on standby in 1958 and has not been used for fuel separations since that date.

A laboratory operated from about 1947 to 1970 and provided analytical services in support of the U Plant operations. Primary waste streams from the laboratory included process waste, used reagents, and wastewaters that were discharged to a reverse well and french drains.

A uranium reduction facility began operation in 1952. It was converted in 1955 to support plutoniumuranium extraction (PUREX) activities.

One tank farm consisting of 16 single-shell tanks, one closed pond, and two identified burial sites are included within the U Plant Aggregate Area.

Z Plant - The Z Plant began operations in 1945 as the Plutonium Isolation Facility, which concentrated plutonium nitrate solution produced by one of the separation facilities (T Plant or B Plant) and converted the concentrate to a plutonium nitrate paste for shipment to Los Alamos for further refinement. This operation took place from 1945 to 1949. The Z Plant Complex, also referred to as the Plutonium Finishing Plant (PFP), operated from 1949 to 1973 and intermittently from 1985 to 1988 . This plant processed the plutonium from the separation facilities to a plutonium metal or plutonium oxide.

The Z Plant process area also included plutonium recovery facilities: the RECUPLEX Facility which operated from 1955 to 1962, and the Plutonium Reclamation Facility which operated from 1964 to 1979 and from 1984 to 1987 . These facilities recovered plutonium from the PFP liquid waste stream. The RECUPLEX Facility was shut down after a criticality event in 1962. A process line also operated from 1949 to 1959 and 1964 to 1976 to recover americium from the PFP waste stream. This facility shut down after an explosion in 1976 in one of the recovery units. Operations in the Z Plant currently are suspended.

There are eight (8) burial grounds within the Z Plant Aggregate Area.

Hanford Central Waste Complex (HCWC) - The Hanford Central Waste Complex is being developed in the 200 West Aggregate Area northwest of the Z Plant. The HCWC will provide facilities for processing radioactive and hazardous solid waste materials in accordance with government regulations. The complex will also contain various facilities that will support waste treatment, storage, or disposal.

Decontamination Laundry - The laundry services have been privatized and this building is no longer in use. The building is scheduled for demolition in FY 1994. 
200 East Aggregate Area - The 200 East Aggregate Area is a controlled area of approximately 7.7 square miles near the middle of the Hanford Site. Operations in this area related mainly to nuclear fuel separation. There are 21 operable units grouped into four aggregate areas, including PUREX Plant, where tributyl phosphate processes separated plutonium from spent uranium fuel rods; B Plant, where bismuth phosphate processes separated plutonium from spent uranium fuel; Semi-Works, where plutoniurn separation technology was developed before full scale implementation; and 200 North, where irradiated nuclear fuel rods were stored before processing; and one aggregate area groundwater operable unit.

The 200 East Aggregate Area also contains nonradioactive support facilities, including transportation maintenance buildings, service stations, a coal-fired powerhouse for process steam production, steam transmission lines, raw water treatment plants, water storage tanks, electrical maintenance facilities, and subsurface sewage disposal systems. This area also contains the grout treatment facility, evaporator, nuclear submarine reactor disposal area, and it is the site of the proposed Hanford Waste Vitrification Plant (HWVP).

Large portions of the 200 East Aggregate Area consist of burial sites, including caissons and various types of burial trenches for the disposal of solid wastes.

Major facilities in the 200 East Aggregate Area:

PUREX - The major processes conducted at the PUREX Plant Aggregate Area have been involved with uranium and plutonium recovery. The PUREX process for recovering uranium and plutonium occurred between 1955 and 1972. After 11 years of non-operation, the plant resumed operations in November 1983; however, it is currently in a standby mode.

Other major structures in the PUREX area include the Evaporator (Waste Volume Reduction Process) and the Condenser Building.

The PUREX Plant Aggregate Area contains eight tank farms. Three, consisting of 26 single-shell tanks, are currently inactive and have undergone initial stabilization. Others, containing 25 double-shell tanks, are currently active. There are five burial grounds within the PUREX Plant Aggregate Area.

B Plant - The major processes at the B Plant Aggregate Area involved extraction of plutonium from nuclear fuels; purification, precipitation, and encapsulation of cesium and strontium from PUREX-derived waste streams; various waste handling processes, such as evaporation; and transfer of single-shell tank waste.

The primary B Plant facility began operation in 194j, ceased plutonium separation operations in 1952, and began various waste treatment operations in 1965. Several additions, such as the Waste Encapsulation and Storage Facility (WESF) and the Cask Transfer Facility, were constructed during this period. The Laboratory supported operations at several 200 Area facilities.

Waste evaporators and in-tank solidification (ITS) units have been used in the B Plant Tank Farms to minimize the volume of tanked waste.

The B Plant Area contains three tank farms, which contain 40 single-shell tanks, as well as thirteen (13) burial sites and seven (7) ponds. 
Semi-Works - The Semi-Works Aggregate Area was composed of two primary facilities, the Process Building and the Critical Mass Laboratory. The Process Building was constructed in 1949 as a pilot plant for reprocessing reactor fuel using the Reduction-Oxidation (REDOX) process. In 1954, the Process Building was converted to a pilot plant for the PUREX process and functioned in this capacity until 1956 when operations were terminated. In 1961, the Process Building was again converted, this time to recover strontium from fission product waste. The facility operated until 1967, during which time it was also used for recovery of cerium, technetium, and promethium. Decommissioning work began in 1983.

The Critical Mass Laboratory operated from 1960 to 1983, conducting criticality experiments and research. Currently, the laboratory is closed, although the administrative offices are used occasionally. There is one pond and one burial ground within the Semi-Works Aggregate Area.

Grout Treatment Facility (GTF) - GTF is an existing TSD unit located within the 200 East Area. It mixes dry cementitious solids with liquid mixed wastes (containing both dangerous and radioactive constituents) produced by Hanford Site operations. The GTF consists of the following components:

- The waste pump pits and transfer piping

- Dry Materials Facility

- Grout Processing Facility

- Grout disposal vaults.

Hanford Waste Vitrification Plant (HWVP) - HWVP currently is under construction and it will be used to vitrify high-level waste into borosilicate glass. The glass will be cast into stainless steel canisters and stored on site until they are shipped to a federal geologic waste repository. The HWVP will be located in the 200 East Area, southwest of the B Plant.

Burial Ground - This unit contains 138 trenches running north and south. As of September 1982, 27 of the trenches were completely full, two were partially filled, and the remaining 109 trenches were empty. The trenches are filled with miscellaneous waste. This area also is used by the Navy for disposal of reactor components from decommissioned nuclear submarines.

Treated Effluent Disposal Facility (TEDF) - The Treated Effluent Disposal Facility currently is under construction on the east side of the 200 Area, outside of the fence. The site is 39 acres in area and will consist of four 6.5 million gallon double-lined surface impoundments with leachate collection systems and floating covers. These impoundments will be used to store dilute aqueous waste from the Purex Evaporator.

300 Area - The 300 Area is located in the southeastern corner of the Hanford Site, just north of the city of Richland, Washington, and encompasses an area of approximately 0.4 square miles. Initial construction at the 300 Area was completed in 1943. It contains facilities associated with the fabrication of nuclear reactor fuel elements. In addition, many technical support, service support, and research and development activities related to fuel fabrication were and are carried out in this area. As the Hanford Site production reactors have been shut down, fuel fabrication activities have decreased. At the same time, research and development activities have increased, especially over the past two decades. The newer buildings in the area house, primarily, laboratory and large test facilities. Current research and development activities focus on peaceful uses of plutonium, including reactor fuels development, liquid metal technology, gas-cooled reactor development, and life science research. The 300 Area consists of three source operable units (300-FF-1, 300-FF-2, and 300-FF-3) and one groundwater operable unit (300-FF-5). Another operable unit, 300-FF-4, is located in the 400 Area. 
The 325 Hazardous Waste Treatment Unit (HWTU), located in the 300 Area, is used to receive, store, and treat small volumes of dangerous waste and radioactive mixed waste (RMW) generated by Hanford Facility Programs. The 325 HWTU is a self-contained waste processing facility located within the 325 Building, which is a concrete and steel building that was constructed in the 1950s. The HWTU occupies a small portion of the second floor of this building and is designed to be a stand-alone unit.

400 Area - The 400 Area is located in the southeastern part of the Hanford Site, approximately 10 miles northwest of the city of Richland, Washington, and encompasses an area of approximately 0.86 square miles. It contains facilities associated with the Fast Flux Test Facility (FFTF), which consists of a 400 megawatt sodium-cooled neutron fast flux reactor. This facility is designed for irradiation testing of fuels and materials and for long-term testing and evaluation of plant components and systems for the Liquid Metal Reactor (LMR) Program. The reactor and ancillary systems are operated by DOE/NE (Nuclear Energy); however, there are some facilities that are under the auspices of EM within the 400 Area. Of 96 assets listed on the Hanford Assets Master Listing for this area, 36 belong to EM, and these consist mostly of storage buildings, mobile offices, pumphouses, and the visitor center.

The Fuels and Materials Examination Facility (FMEF), located adjacent to the Fast Flux Test Facility, is a modern nuclear materials processing facility. It has six operating levels and includes over 200,000 square feet in the main process building. The FMEF was originally intended as a breeder reactor laboratory where irradiated fuel and reactor components would be analyzed. However, those plans were tied to a breeder reactor research program that was terminated by Congress. There is a nearly completed Secure Automated Fabrication (SAF) line for fuel fabrication on the sixth level. A conceptual design for a prototype LMR reprocessing plant, the Breeder Reprocessing Engineering Test (BRET) Facility, was also completed. The FMEF has been maintained in a standby condition and is ready for a mission assignment.

The 400 Area contains the 300-FF-4 operable unit.

600 Area - The 600 Area includes all land within the Hanford Site that is not otherwise within the 100, 200,300, 400 , or 1100 areas. The 600 Area consists mostly of undeveloped land and some relatively remote facilities.

700 Area - The 700 Area, located outside of the Hanford Site in downtown Richland, encompasses an area of approximately 22 acres. It is comprised primarily of administrative buildings, which are centered around the Federal Building.

1100 Area - The 1100 Area, located near the southeastern corner of the site, just north of the city of Richland, Washington, encompasses an area of approximately 90 acres. This area consists of central warehousing, vehicle maintenance, and the transportation distribution center, and it is the main portal to the Hanford Site. For purposes of environmental restoration, this area is divided into two operable units (1100-EM-1 and 1100-EM-2).

3000 Area - The 3000 Area, located near the southeastern corner of the site, is considered a part of the Hanford Site, even though it is not situated within the site boundaries. It encompasses an area of approximately 64 acres and it consists of the Kaiser Construction support facilities, as well as technical support and training facilities and fabrication and maintenance shops. This area contains the 1100-EM-3 operable unit. 


\section{HANFORD SITE}

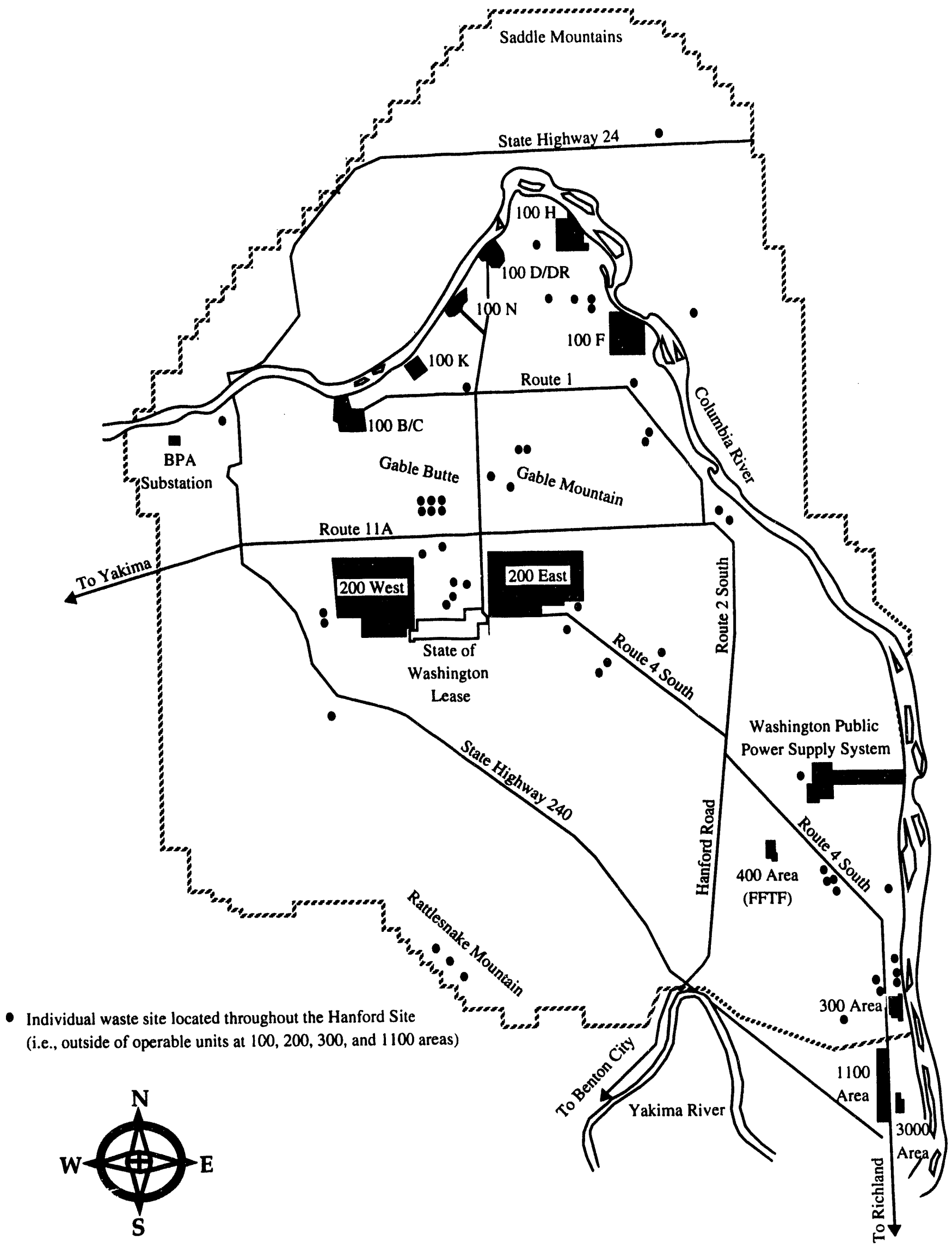


HANFORD SITE

100-B AND C AREAS

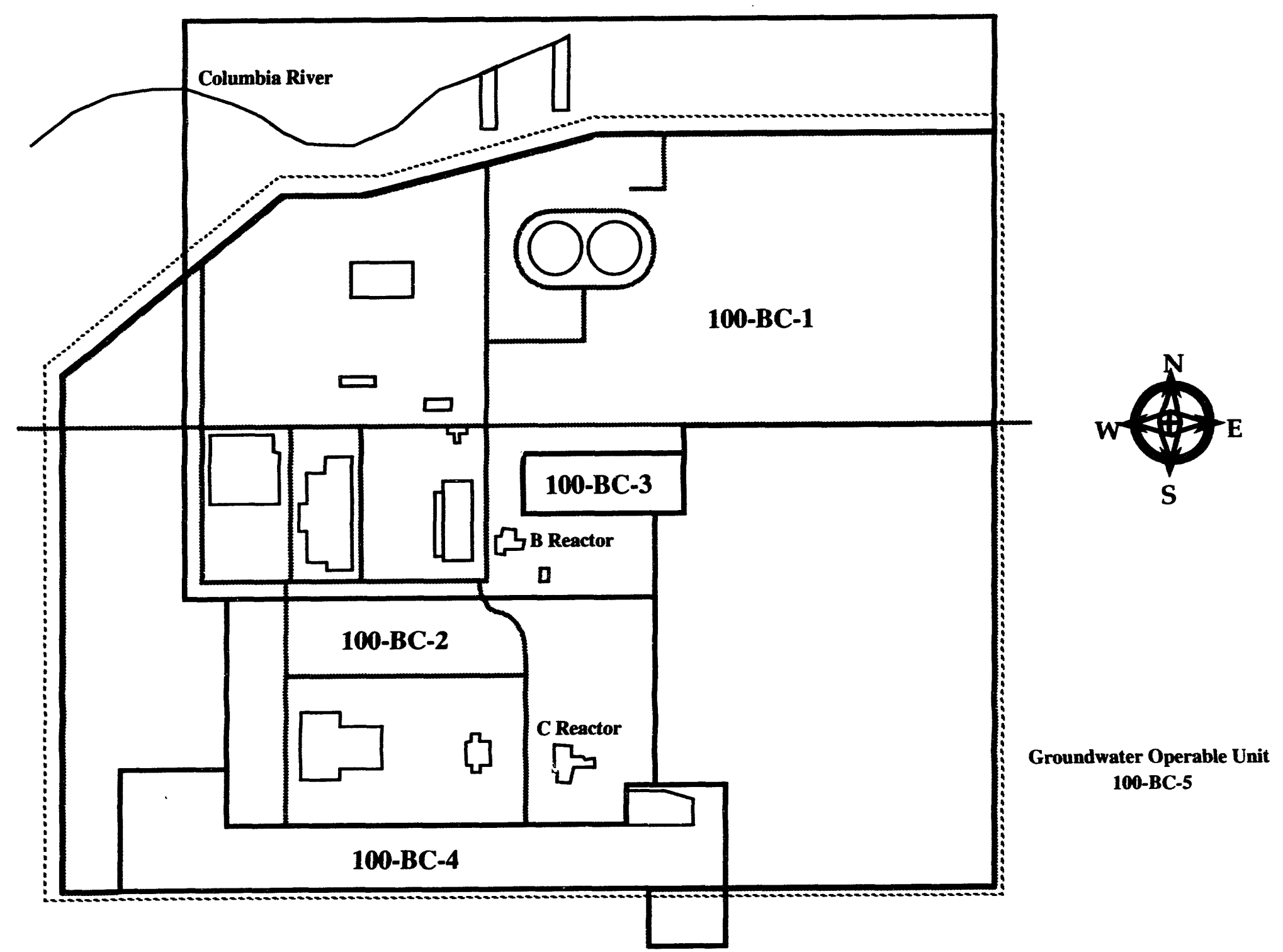



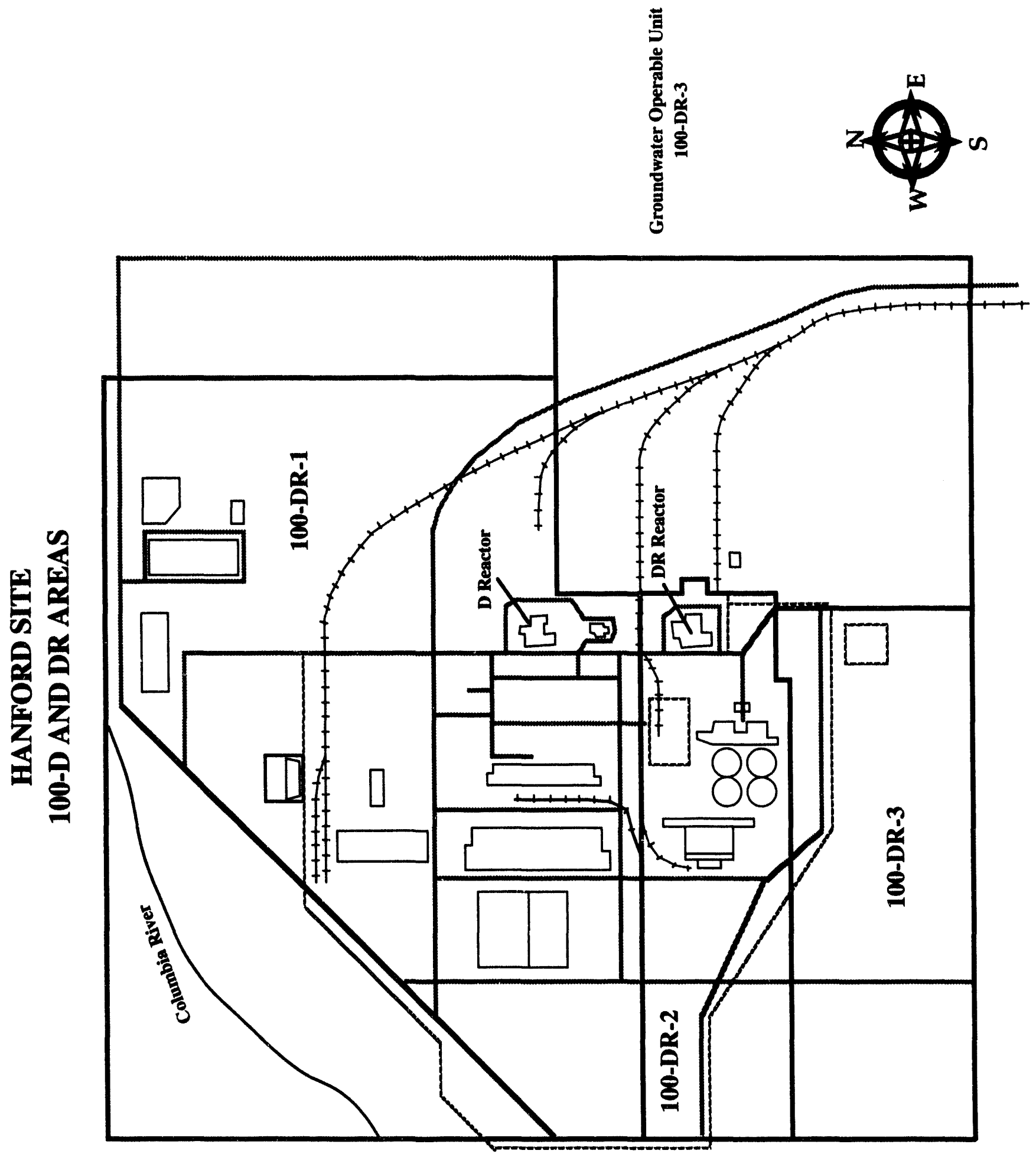
HANFORD SITE

100-F AREA

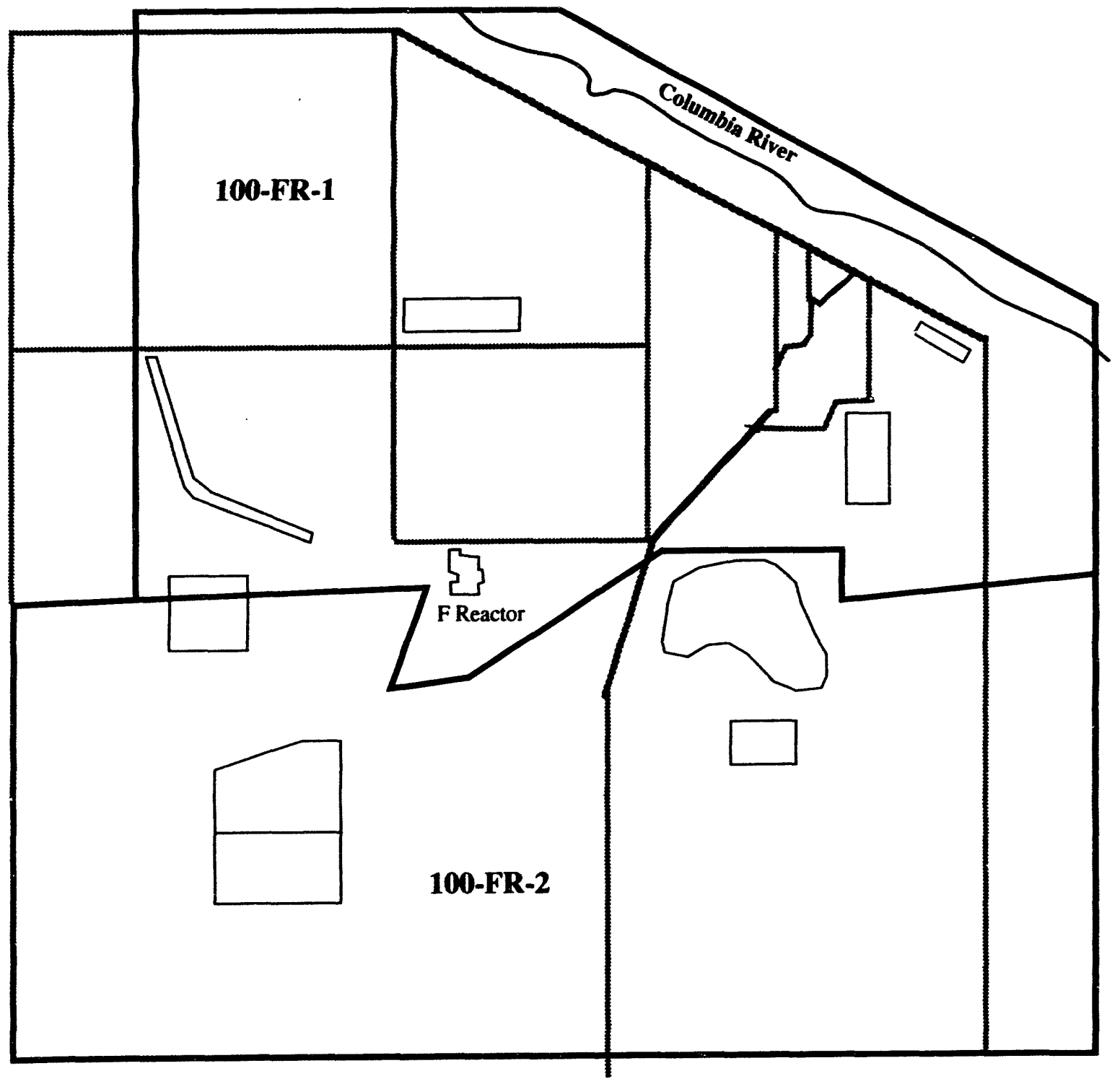

Groundwater Operable Unit 100-FR-3

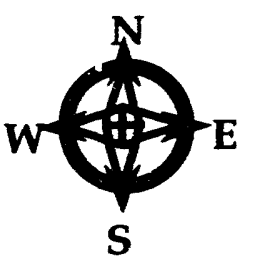


HANFORD SITE

100-H AREA

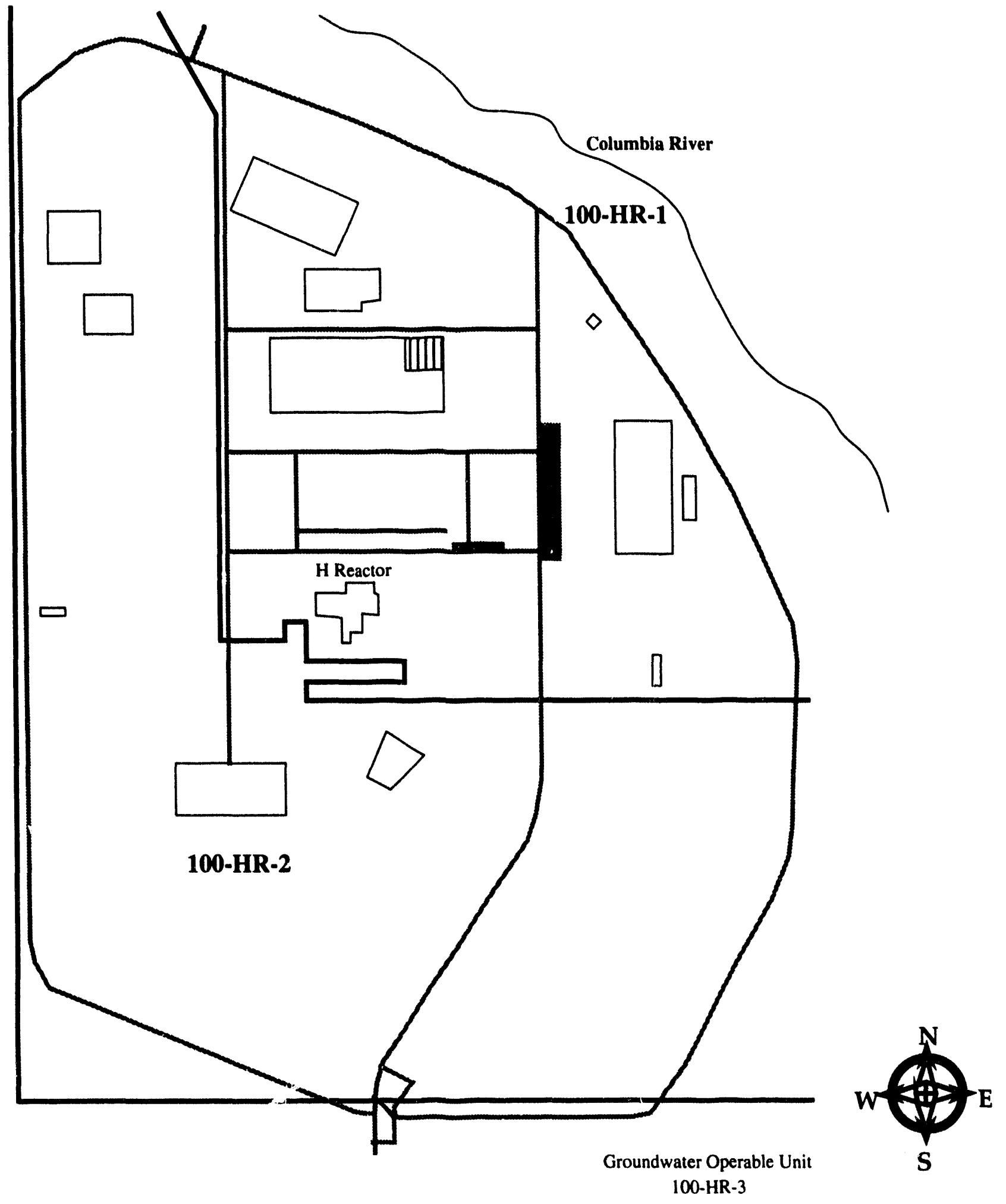


HANFORD SITE

100-K AREA

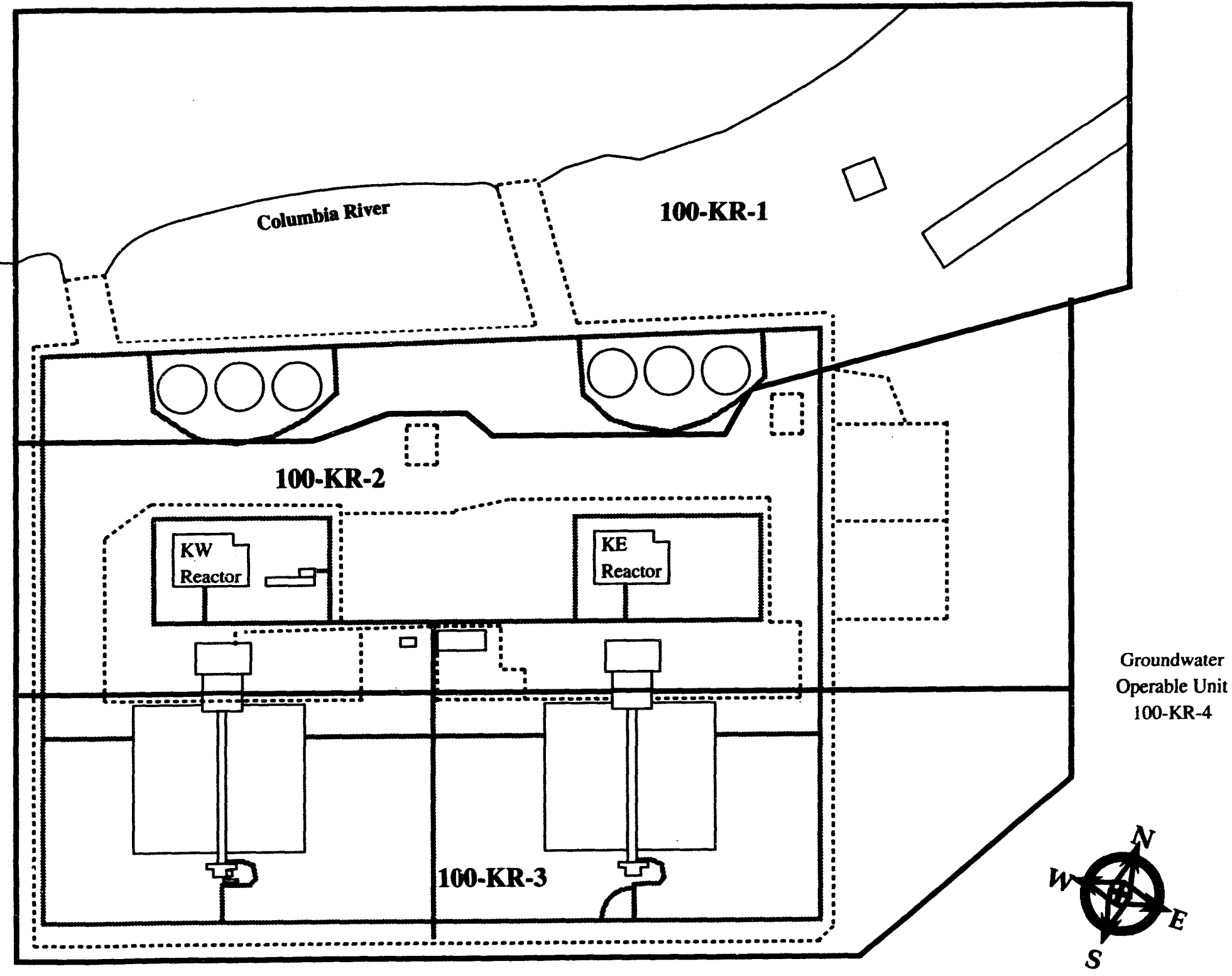




\section{HANFORD SITE \\ 100-N AREA}

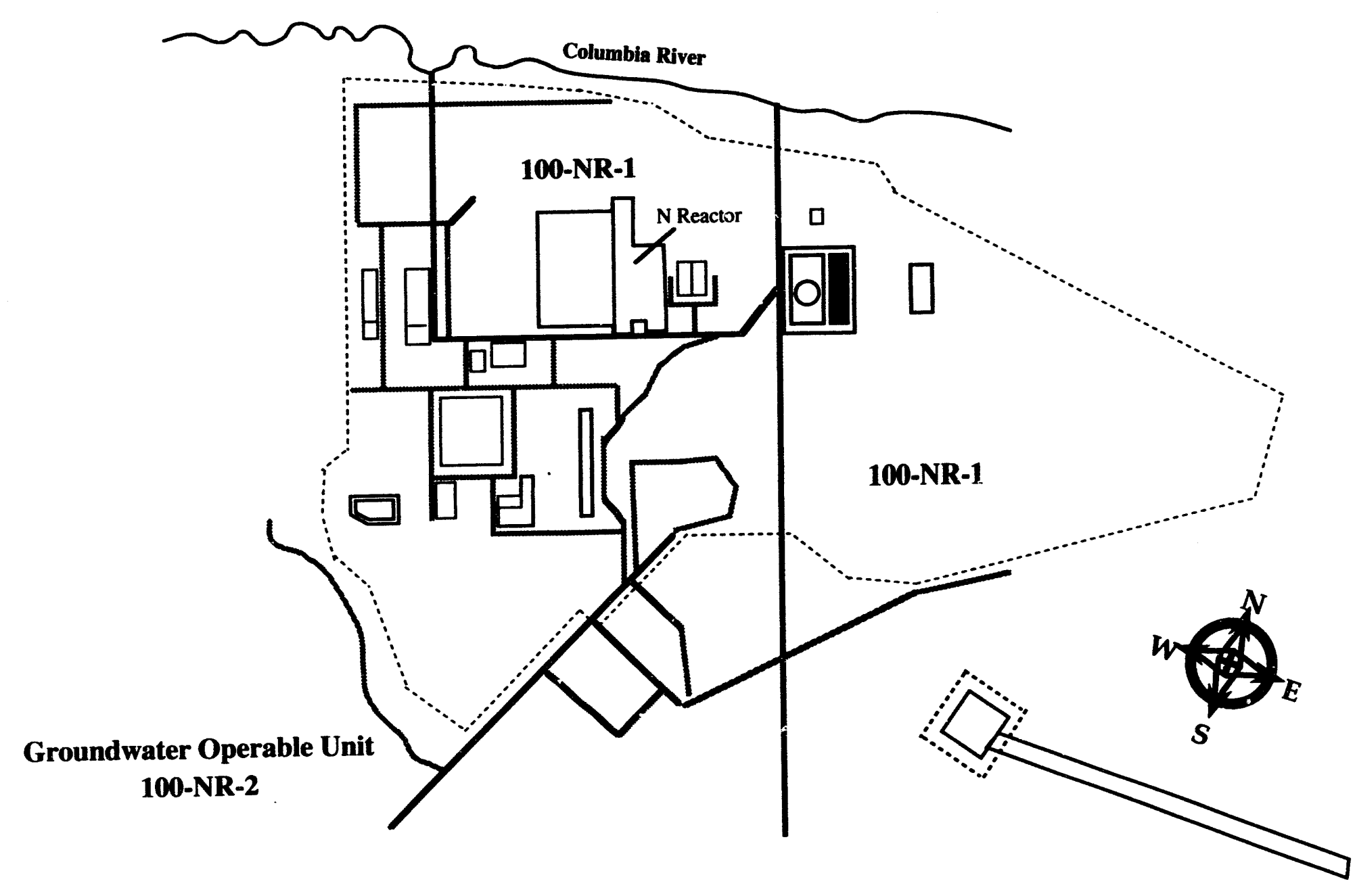


HANFORD SITE

200 WEST AREA

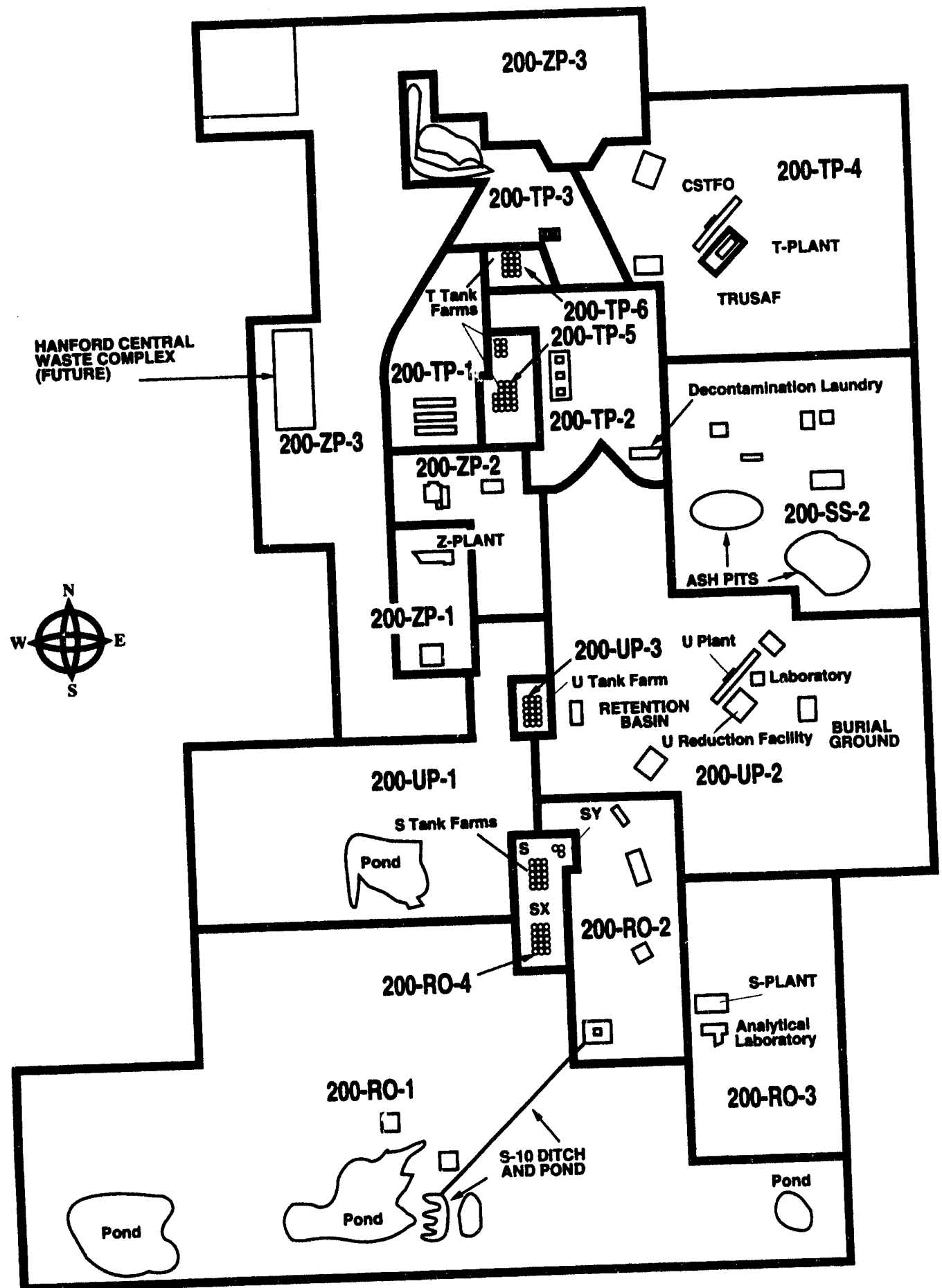

Aggregate Groundwater Operable Unit 200-W 


\section{HANFORD SITE \\ 200 EAST AREA}

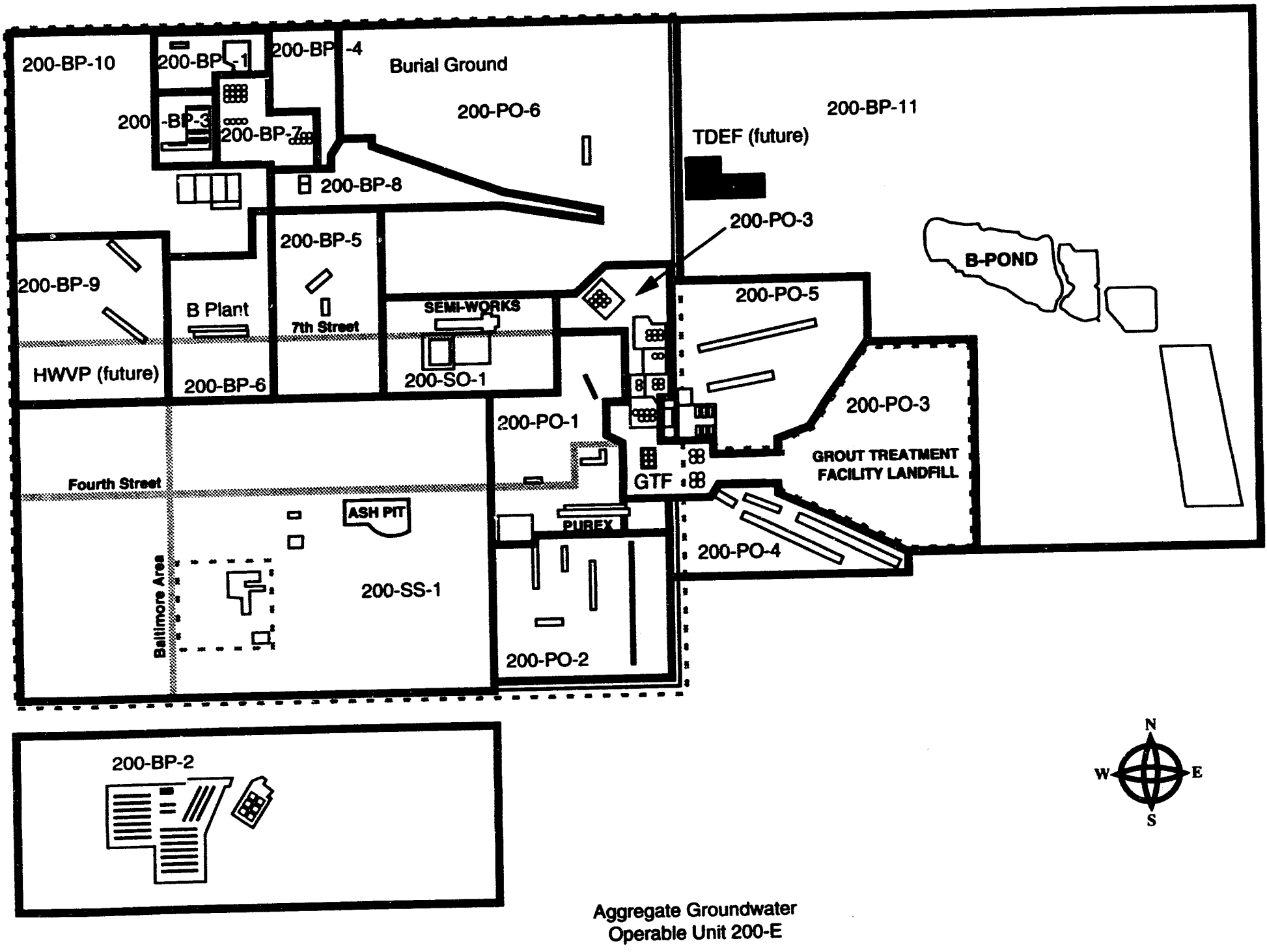



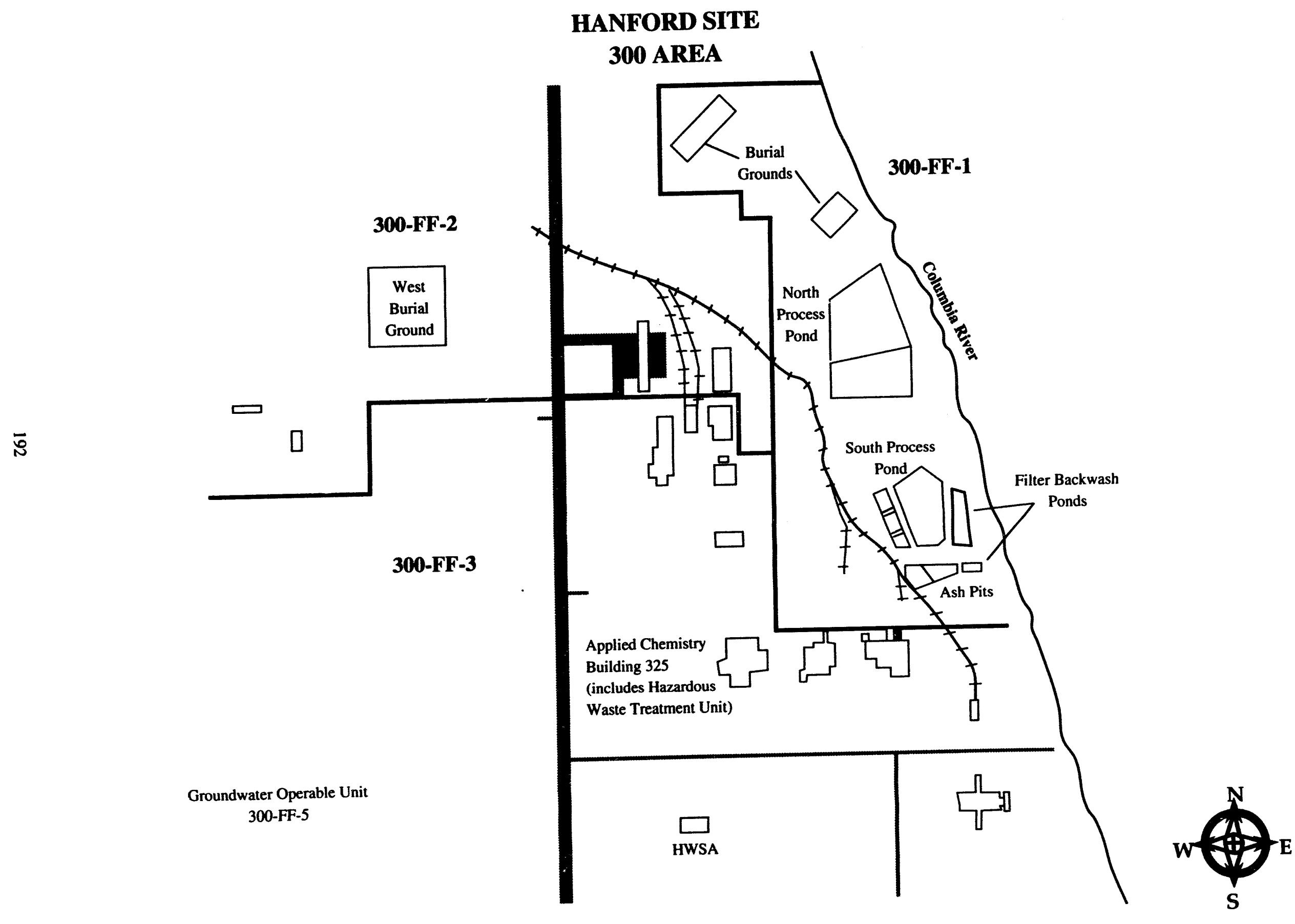


\section{HANFORD SITE}

400 Area

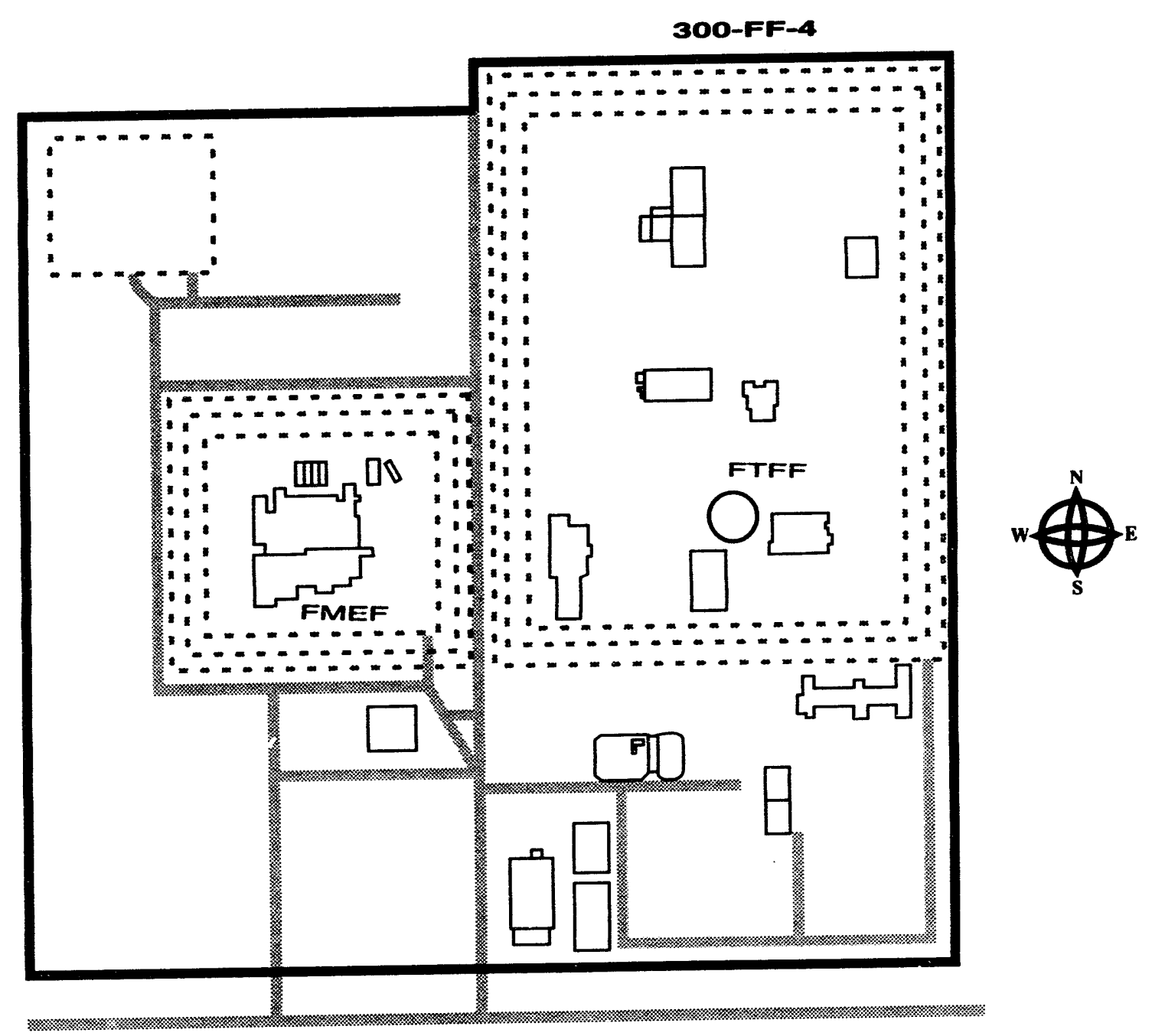




\section{HANFORD SITE}

1100 AREA

- Environmental Remediation Sites

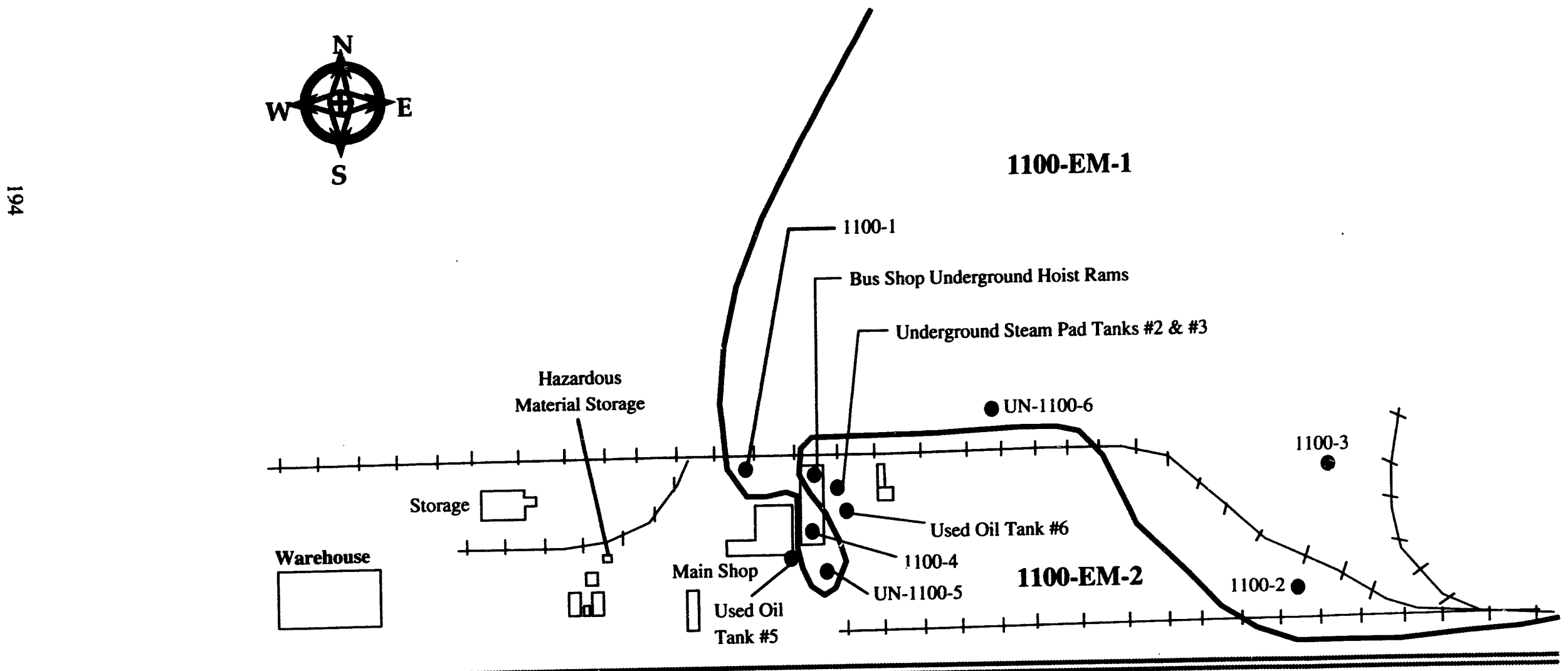




\section{Hanford Site}

3000 Area

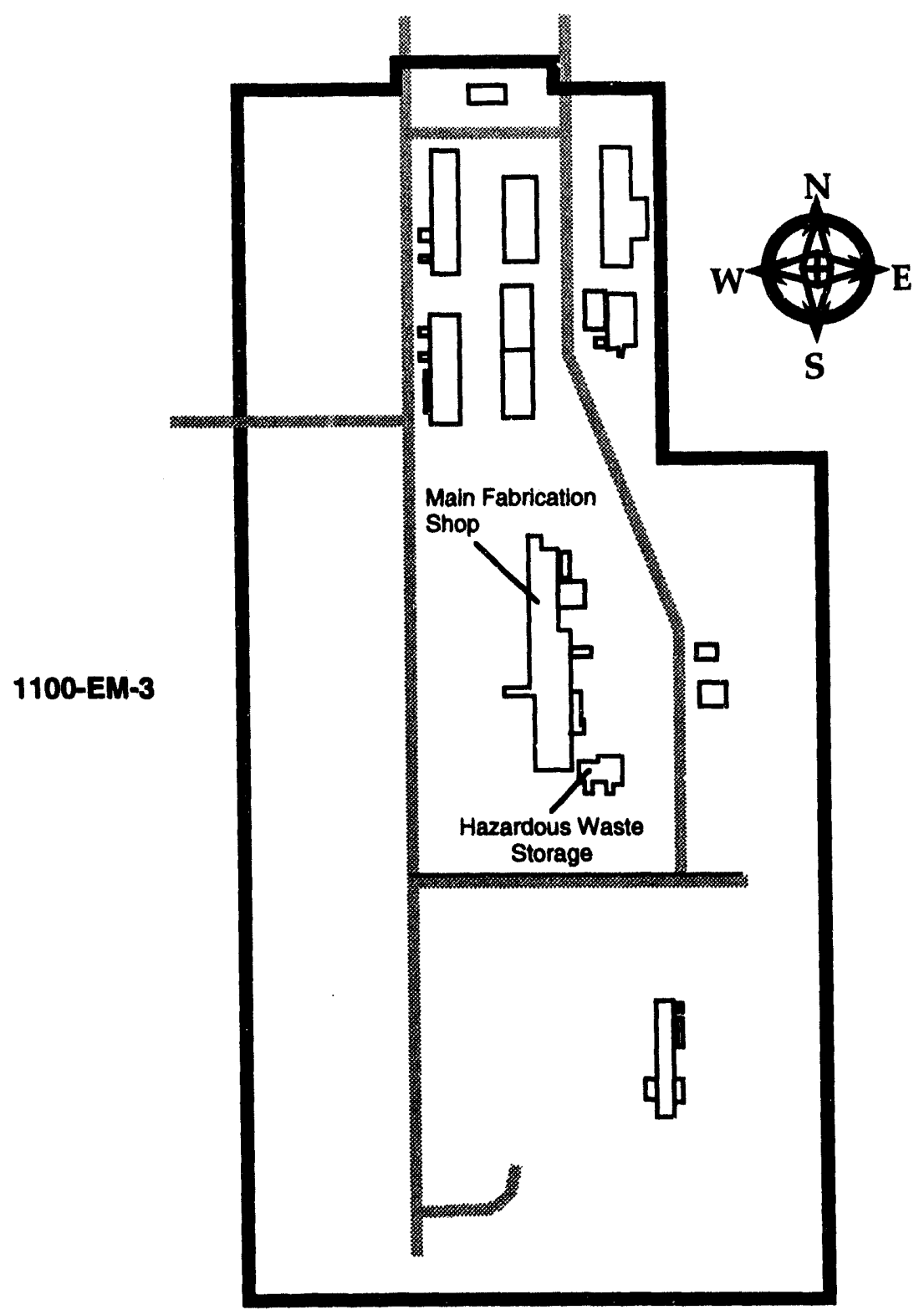




\section{ROCKY FLATS PLANT}

\section{ENVIRONMENTAL RESTORATION AND \\ WASTE MANAGEMENT FACILITIES}

\section{DESCRIPTION}

Rocky Flats Plant (RFP) is located in northern Jefferson County, approximately 16 air miles northwest of Denver, Colorado, and covers almost 11 square miles. RFP's primary mission before January 1992 was to produce nuclear weapons components fabricated from plutonium and other metals; the mission has now changed to cleanup, waste management, and decontamination and decommissioning (D\&D). Sites being investigated for possible contamination have been organized into 16 operable units (OUs), which contain individual hazardous substance sites (IHSSs) to be remediated under either CERCLA or RCRA guidelines, per the Interagency Agreement (IAG) negotiated among EPA, the Colorado Department of Health (CDH), and DOE. Waste management activities at RFP include waste treatment, packaging, storage, and transport functions. These activities are carried out in the most efficient manner possible, while maintaining strict regulatory compliance and protecting human health and the environment. Technology development is investigating the technology needed to resolve critical waste management and environmental restoration problems and issues. The transition of buildings from Defense Programs to EM, that began in FY 1993, includes interim reuse for possible economic development and final $D \& D$ activities.

\section{AGREEMENTS}

\section{Statute/Type}

Agreement-in-Principle

RCRA Compliance

Agreement

RCRA Compliance

Agreement (LDR)

CERCLA/RCRA Compliance

Agreement

RCRA Clean Air Act/

NESHAPS Compliance

Agreement

CERCLA/ RCRA

Compliance Agreement

RCRA (Residues) Compliance Agreement
RFP

Facilities

RFP

RFP

RFP

RFP

RFP

RFP
Parties

$\mathrm{DOE} / \mathrm{CO}$

DOE/EPA/CO

DOE/EPA

DOE/EPA/CO

DOE/EPA

DOE/EPA/CO

DOE/CO
Signed 5/10/91

Status

Signed 6/28/89

Signed 9/19/89

Signed 7/14/89

Signed 1/22/91

Signed 7/31/86
Signed 11/3/89 


\section{FACILITIES AND PROJECTS}

As a result of the Secretary's announcement on December 16, 1991, DOE is accelerating plans for its "preferred option" to consolidate most of its nonnuclear manufacturing activities at the Kansas City Plant. In the case of RFP, the stainless steel manufacturing work would be transferred to the Kansas City Plant and beryllium work would be relocated to the Y-12 Plant in Tennessee where similar work is currently assigned. Upon transfer of this production work from RFP, which is expected to occur by the end of FY 1994, all these nonplutonium buildings would be transferred to EM for use in fulfilling EM's mission at RFP. If the buildings are declared excess to DOE use, they may be made available for other industrial/commercial purposes.

On January 15, 1993, the Office of Environmental Restoration and Waste Management (EM) assumed the responsibility for all facilities at the Rocky Flats Plant (RFP) except for Buildings 440, 444, 460, and 883, and their support buildings.

\section{Building 371}

Description - Building 371 became operational in 1981. This facility is a four level, partially buried structure of reinforced concrete and contains approximately 186,000 square feet of floor space. This building was designed and built to withstand the damaging effects of earthquakes, tornado, wind, and fire.

Production Mission - Building 371 was originally designed for the physical and chemical operations for recovering and refining plutonium metal and was intended to replace the recovery processes in Buildings 771 and 776. In addition to the recovery facilities, Building 371 also includes analytical laboratories, standards laboratories, and storage areas. Recovery operations were eventually terminated when 371 operations failed to achieve the level of performance required to replace Buildings 771 and 776.

Current Status - Building 371 is classified as a non-reactor nuclear facility. Building 371 is currently being utilized for storage of plutonium radioactive waste, and analytical standards and laboratory support. The analytical laboratories provide services for liquid waste operations, plant utilities, the plant laundry, and for consolidation of SNM. The standards laboratories provide support to liquid waste operation, plant utilities, plant laundry and SNM consoli Jation.

\section{Buildings 374.774}

Description - Building 374 was built in the late 1970's and became operational in 1980. Total floor space area in 374 is approximately 66,330 square feet. Building 774 was constructed in 1952.

Building Mission - Buildings 374 and 774 are responsible for treatment of liquid process wastes to remove chemical and radioactive constituents. Some wastes are piped directly from the waste generating building or are transferred in various container configurations such as drums or tanks.

Current Status - Both 374 and 774 are classified as non-reactor nuclear facilities. Both of these buildings will continue to operate for the foreseeable future to support plantwide operations. Both facilities are being examined for emergency preparedness. Plans and procedure will be developed as necessary to meet the emergency preparedness requirements of DOE Order 5500.3A.

\section{Building 559}

Description - Building 559 was constructed in 1966-67 and became operational in 1968. Total area in this facility is approximately 32,890 square feet. 
Production Mission - Building 559 was originally constructed to provide a modern chemical analytical laboratory to support plutonium production operations.

Current Status - Building 559 is classified as a non-reactor nuclear facility and is identified as Category III, which restricts the total amount of plutonium in the building to 2.0 kilograms. As with all plutonium operations at Rocky Flats, activities in Building 559 were curtailed in November of 1989. After a rigorous and successful effort to implement changes that will assure operational safety, the DOE Assistant Secretary for Defense Programs and the DOE Rocky Flats Office authorized the resumption of all analytical operations in Building 559. These analytical operations provide support for a variety of plant activities, including the Waste Stream and Residue Identification and Characterization (WSRIC) Program, consolidation of nuclear materials, stabilization of plutonium, analysis and characterization of low level waste, and analysis in support of environmental restoration, waste management, and decontamination/decommissioning.

\section{Building 569}

Description - Building 569 has a total floor space of approximately 8,000 square feet and is located in the Rocky Flats Plant Protected Area.

Building Mission - Building 569 was constructed to determine the radinactive assays of waste containers. The assay measurements, which are established with radiometric scanning equipment, are utilized to determine if waste containers contain low level waste or TRU waste.

Current Status - Building 569 is classified as a non-reactor nuclear facility. This building continues to operate to support plant waste management activities.

\section{Buildings 664.964}

Description - Building 664 is currently permitted to store a total of 2,500 cubic yards of waste; Building 964 's storage capacity is 610 cubic yards.

Building Mission - Buildings 664 and 964 were constructed for the storage and shipment of radioactive waste.

Curcent Status - Both Building 664 and Building 964 are classified as non-reactor nuclear facilities. Building 664 stores low level, low level mixed, and TRU mixed wastes. Building 964 stores low level and low level mixed waste. Building 664 also contains a real-time radiography system used for assuring that waste containers comply with waste acceptance criteria.

Future Use - Buildings 664 and Building 964 will continue to operate to provide waste storage for the Rocky Flats Plant. Emergency preparedness plans will be developed and implemented to meet the requirements of DOE Order 5500.3A.

\section{Building 707}

Description - The construction of Building 707 began in 1968 and was completed in 1970. At the time of construction, 707 reflected the latest design criteria and engineering technology. Efforts to complete the construction of this facility were accelerated following the 1969 fire in Building 776, which caused extensive damage and contamination to both Buildings 776 and 777 . The main floor is divided into eight modules, with each module being dedicated to specific manufacturing processes, e.g., foundry operations, machining, inspection, etc. 
Production Mission - Building 707 was constructed to provide the weapons complex with a modern plutonium manufacturing and assembly facility with increased production capacity and up-to-date technologies and processes. Until curtailment of operations in 1989, Building 707 was the only facility in the weapons complex that was capable of producing production quantities of pit assemblies for the U.S. nuclear weapons stockpile. Plutonium components, which were produced in Building 707, were assembled with components and subassemblies produced in other Rocky Flats facilities, such as Buildings 444 and 460 . Some pit assemblies also included enriched uranium components produced by the Y-12 Plant.

\section{Building 771}

Description - Building 771 was constructed in 1951 and is a two story, structural frame building of reinforced concrete. This facility covers a surface area of approximately 300 feet by 260 feet and has a total building area of 147,910 feet.

Production Mission - Building 771 was originally constructed as a complete plutonium fabrication and recovery facility. The responsibility for plutonium fabrication operations was assumed by Buildings 776 and 777 when construction of those facilities was completed in the late 1950's. The Building 771 mission was then focused on the recovery of plutonium from manufacturing residues generated by the fabrication processes in the other plutonium production buildings. This building also contains analytical and metallurgical laboratories that supported production, recovery, and waste disposal operations.

Current Status - All production operations in Building 771 remain shutdown. Limited operations are being performed in the Analytical Laboratory and the Nondestructive Assay facility in support of waste management and safeguards requirements. Activities are in process to dispose of solutions and chemicals and to accomplish the transfer of plutonium materials to Building 371.

\section{Building 776/777}

Description - Building 776 was constructed in 1956 and became operational in 1957. Ten major modifications have been made to this building, including the addition of Building 777. The Building 776/777 complex is a two story, structural steel frame facility with a reinforced concrete slab floor. Total floor area is approximately 223,000 square feet with approximately 135,000 square feet on the first floor and 88,000 square feet on the second floor.

Production Mission - The building 776/777 complex was the major Rocky Flats plutonium fabrication and assembly facility until Building 707 became operational in 1970. Operations performed in Building 776 included casting, rolling, forming, machining, and inspection of plutonium components. The final assembly, inspection, and testing operations were performed in Building 777. Operations in the Building 776/777 complex were shut down for several months in 1969 following a major fire. Although direct fire damage was limited to Building 776, high levels of radioactive contamination spread to Building 777 . Operations in these buildings were able to resume after several months of intensive decontamination efforts.

Current Status - All production operations in Building 776/777 remain shutdown. This facility is considered to be a high hazard area due to the large amounts of plutonium currently being stored there. The building is now being used for various waste operations.

\section{Building 779}

Description - Building 779 was built in 1965. Two major additions, 779A and 779B, were completed in 1968 and 1973, respectively. A structural upgrade was completed in 1988 to provide added resistance to damage from eathquake and high winds. Total surface area of this building is 67,710 square feet. 
Production Mission - Building 779 was constructed to provide a research and development facility for the support of plutonium production and recovery processes. No significant change had occurred in this mission until operations were curtailed in 1989.

Current Status - All production-related activities remain shutdown. A minimal level of activity continues in support of non-nuclear production and for research associated with advanced cleaning technologies. Several pieces of analytical and laboratory equipment in 779 have been identified for transfer to the Los Alamos National Laboratory to support the transfer of the stockpile surveillance mission to that site.

\section{Building 788}

Description - Building 788, which is located in the Rocky Flats Protected Area, has a total floor area of approximately 5,600 square feet.

Building Mission - Building 788 was originally used for the processing of Pondcrete, which is a mixture of solar pond sludge containing low levels of radioactive contamination and Portland cement.

Current Status - Building 788 is classified as a non-reactor nuclear facility. Activities in this building are currently limited to storage of low level waste.

\section{Building 865}

Description - Building 865, which was completed in 1970, was constructed using concrete exterior walls, concrete floor, and concrete tie beams that are irtegral with the floor. This building has a total area of approximately 37,980 squar. iet.

Production Mission - Building 865 's primary mission was to provide a facility for developing new metal working processes for the production of weapons components. These processes include extrusion, spin forming, rolling, forming, casting, and swaging. The materials used in these development efforts include beryllium, uranium, stainless steel, aluminum, and vanadium.

Current Status - Because of work involving depleted uranium, Building 865 is classified as a non-reactor nuclear facility. In FY93, the responsibility for Building 865 was transferred from Defense Programs to Environmental Management. With the exception of a small amount of research work, all production-related activities have been terminated. All uranium and beryllium materials have been removed and shipped to other buildings for storage. All classified parts, tooling, and documents have been destroyed or have been transferred to other buildings for storage.

\section{Building 881}

Description - Construction of building 881 was completed in 1953. This facility is a three-story structure of reinforced concrete, with most of the building being underground. The total floor space in 881 is approximately 245,160 square feet.

Production Mission - The original purpose for the construction of Building 881 was for the processing and machining of enriched uranium (Oralloy) into finished weapons components. The Oralloy processes included chemical recovery operations and foundry equipment for supplying metal to the rolling and forming operations in Building 883. Production of Oralloy components ceased in 1967 when the sole responsibility for Oralloy production was assumed by the Y-12 Plant. In 1968, the mission assignment for manufacturing gas reservoir 
assemblies for weapons applications was transferred to Rocky Flats from a DOE facility in Albuquerque, New Mexico. Building 881 was selected as the most suitable site for the manufacture of these assemblies. This work continued in Building 881 until 1985 when this work was transferred to the newly-constructed Building 460.

\section{Building 886}

Description - Construction of Building 886 was completed in 1964. Because of the nature of the work performed in this building, construction consists of very thick concrete walls. The total floor space for Building 886 , including an adjoining modular office building, is approximately 10,360 square feet.

Production Mission - The mission of this facility was to perform criticality experiments and measurements in order to establish criticality limits and assure the safe handling and processing of fissile materials. This effort supported Rocky Flats activities and assisted the Nuclear Regulatory Commission in the setting of safety standards.

Current Status - Efforts are under way to remove the fissile materials from Building 886.

\section{Building 889}

Description - Building 889 was constructed in the early 1970's and contains approximately 5,000 square feet of floor space.

Building Mission - Building 889 was constructed to provide a facility for decontamination, waste compaction, and storage of wastes contaminated with depleted uranium.

Current Status - Building 889 is classified as a non-reactor nuclear facility. This building is not operational at this time.

\section{Building 991}

Description - Building 991, which was one of the first permanent buildings constructed at Rocky Flats, became operational in 1952 . This facility has a total area of 40,780 square feet, with 35,590 square feet on the main level and 5,190 square feet on the basement level. This building is constructed of 1 to 1.5 foot thick reinforced concrete. Tunnels and vaults in this building have reinforced concrete walls that are up to 14.5 feet thick.

Production Mission - Building 991's original mission was for the final assembly of weapons components. Finish machined components and subassemblies were received from Rocky Flats production buildings as well as from other facilities in the weapons complex and were assembled, tested, and inspected in Building 991. Transfer of assembly operations out of Building 991 was initiated when construction of Building 777 was completed. This transfer was completed by 1965. Operations remaining in Building 991 after 1965 included research and development, shipping, receiving, and storage.

Current Status - Building 991 is classified as a non-reactor nuclear facility. A variety of plantwide activities and services are currently provided by Building 991 , including supplying of certified packaging for storage and shipment of nuclear materials; offsite shipment of low level waste; performing metallurgical evaluations on weapons products and materials; evaluations of cleaning processes; and non-destructive testing (radiography and dye pe . trant) of waste containers, hoist hooks, pipe welds, and storage tanks. Building 991 also plays an important role in the Rocky Flats responsibility for storing special nuclear materials (SNM). 


\section{Building 995}

Description - Building 995 was constructed in 1952; the floor space, in the administrative areas only, is approximately 1,000 square feet.

Building Mission - Building 995 is the only sewage treatment facility at the Rocky Flats Plant. Sanitary waste generated at Rocky Flats is treated prior to offsite release.

Current Status - This facility continues to operate to provide treatment of sanitary waste generated by the Rocky Flats Plant. An assessment is currently under way to determine if radioactivity levels in the waste sludge warrant classification as a non-reactor nuclear facility.

\section{Storage Pads $-750,904$}

Description - Storage Pads 750 and 904 are outside storage facilities. Pad 750 has a surface area of approximately 130,000; Pad 904 has a surface of approximately 104,400 square feet.

Mission - These two storage pads were originally utilized as vehicle parking spaces. Use of these pads, for storage of waste boxes containing Pondcrete and Saltcrete, began in 1987.

Current Status - Storage Pads 750 and 904 are classified as non-reactor nuclear facilities. Both pads continue to operate to support plant waste management activities.

\section{Sanitary Landfill}

Description - The Sanitary Landfill is located on 25 acres, north of the Plant in the Buffer Zone. This facility has been in operation since 1968.

Mission - The landfill was established for the disposal of solid sanitary waste generated by the Rocky Flats Plant. No disposal of liquids, infectious waste, radicactively contaminated waste, or hazardous waste is permitted at the landfill.

Current Status - The existing landfill will continue in operation until the maximum capacity is reached, which is estimated to be approximately 5 years.

\section{Site Support Facilities (Security, Medical, Utilities, etc.)}

Description - A total of 224 buildings are included in the facilities that provide infrastructure support to the Rocky Flats Plant.

Production Mission - These facilities were constructed to provide a wide range of services required by the Rocky Flats Plant, including security, medical, fire protection, warehousing, utilities, garage, maintenance, fuel storage, paint shop, etc.

Current Status - All of these facilities remain operational. Because of space shortages in on-site facilities, additional offsite buildings have been leased for office and classroom space. 


\section{ROCKY FLATS PLANT}

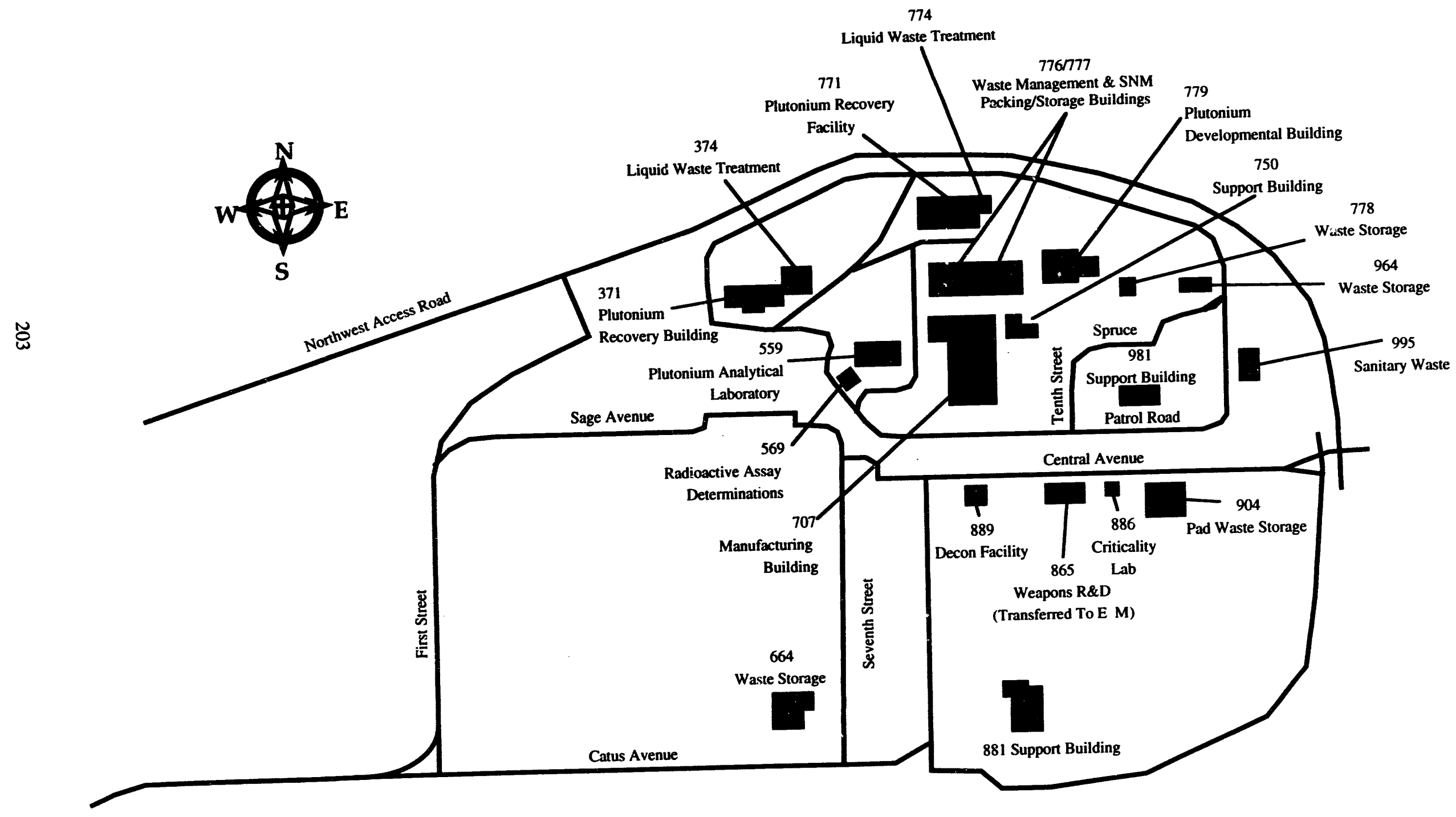




\section{LABORATORY FOR ENERGY-RELATED HEALTH RESEARCH}

\section{ENVIRONMENTAL RESTORATION AND WASTE MANAGEMENT FACILITIES}

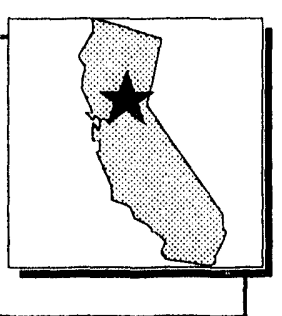

\section{DESCRIPTION}

The DOE-owned Laboratory for Energy-Related Health Research (LEHR) occupies a 15-acre site south of the main campus of the University of California at Davis (UCD). The site, leased from UCD, is surrounded by scattered campus research facilities and private farms. For more than 30 years, the laboratory was used by UCD to conduct a DOE-sponsored research program on the health effects of exposure to low levels if radiation. Research activities contaminated five buildings, outdoor dog pens and cages, and a tank trailer; and generated radioactive sludge wastes and contaminated soils in trenches and pits. Some chemical and radioactive contaminants have reached the groundwater.

\section{AGREEMENTS}

Statute/Type

Memorandum of Agreement

Agreement-in-Principle
Facilities

LEHR

LEHR
Parties

DOE/UCD

DOE/CA

\section{$\underline{\text { Status }}$}

Completed 3/13/90

Completed 9/6/90

\section{FACILITIES AND PROJECTS}

\section{Environmental Assessment. Decontamination and Decommissioning}

\section{Animal Hospital \#1 \\ Animal Hospital \#2}

These two facilities were utilized to house beagle dogs during the ingestion phase of exposure studies at the LEHR project. Beagles were fed diets supplernented with Ra226 and given Strontium 90 injections after which they were held in these facilities and studied until their excretions showed that most of the radionuclides had been excreted. In addition to cages, these facilities included food mixing areas and a surgery for diagnostic and postmortem activities. Both facilities were contaminated with strontium and radium (primarily surface) and the associated drain plumbing is contaminated. Clean up (D\&D) of both facilities was completed September 1993. 
Imhoff Facility

Imhoff Sludge Tanks

Ra 226 Seepage Pits and Leach Line

Sr-90 Leach Field

All of these "facilities" make up a sophisticated "septic tank system" which received the outflow from the cages in the animal hospitals. A separate system handled Ra226 and Sr-90 wastes although there are indications that crossover occurred. Wastes basically passed to the Imhoff Facility (septic tank) and then to the leach lines, fields and seepage pits as in an ordinary septic system except that the outflow was passed through an ion exchange system to remove most of the Sr-90. The Imhoff tanks were emptied of 36,000 gallons of sludge which had been solidified and shipped to Hanford for disposal during FY 1992. The leach fields are contaminated with radium and strontium, however there is no indication of migration.

Remediation of all of these facilities is expected to be complete by FY 1996.

\section{Dog Pens}

These outdoor pen areas housed the animals during periods when they were not excreting significant amounts of radionuclides. A limited amount of radium and strontium contamination is present in the gravel floors of these cages. Remediation of this area is planned for FY 1996.

\section{Cobalt 60 Source/Building} Cobalt 60 Annex

This facility housed (on the roof) a cobalt 60 pencil source $(140 \mathrm{ci})$, for use in direct radiation studies. The source was in a remotely operated shielded container on the roof of the building. Removal and reuse, by private industry, of this source was completed in January 1993, and the source building and support building will undergo D\&D by FY 1996.

\section{Tanker}

This is an old tank trailer that was used as an "overflow" for the Imhoff septic facility during LEHR operations. The tanker currently contains approximately 250 gallons of rainwater that is contaminated with low levels of strontium and radium. Remediation (disposal) of this tanker is scheduled for FY 1994.

\section{Remediation}

\section{Old UCD Landfills}

Two of three UCD landfills are located under portions of the LEHR Facility. These landfills received refuse from campus activities primarily. There are undocumented reports of DOE waste from the LEHR project also being disposed of in these landfills. The ländfills are known to be leaking both hazardous and radioactive materials to the groundwater. Principal contaminants identified thus far are Carbon 14, Hexavalent Chromium, and Tritium. None of these contaminants were used in LEHR studies in significant quantities. One principal objective of the current assessment activities is to determine DOE liability, if any, associated with these landfills and groundwater. The DOE baseline project does not encompass any remediation of the landfills or groundwater. 


\section{Radioactive Trench and Hole Areas (DOE and UCD)}

These indicated areas are where DOE and the University disposed of "acceptably low levels" of radioactive waste during the project years. DOE trenches are known to contain radium and strontium contaminated materials. UCD trenches are known to contain Carbon 14, and Tritium wastes. These trench areas have been roughly located from above ground evidence and records. Detailed characterization and assessment of DOE trenches are included in the CERCLA Remedial Investigation and Feasability Study (RI/FS). UCD trenches will be characterized in sufficient detail to enable determination of DOE responsibility for clean up. RI/FS is expected to be completed in late 1995.

\section{Released Facilities}

\section{Main Office Building}

Clinic

Cell Biology Laboratory

Shop

Toxic Pollutant Research

Small Animal Building

Storage

These facilities housed the office complex and non-radioactive experimental laboratories for the LEHR project. They have been surveyed, found to be clean, and released to the University of California. They are currently used for laboratory space for the Institute for Environmental Health and Toxicology (ITEH).

\section{Geriatrics 1}

Geriatrics 2

These facilities were used for receipt and quarantine of animals during the LEHR project. Neither building is contaminated and both have been released to the University of California for ongoing campus research. A portion of Geriatrics 1 has been modified for use as a waste staging area during the LEHR remediation project. 


\section{LABORATORY FOR ENERGY-RELATED HEALTH RESEARCH SITE MAP SHOWING PRIMARY AREAS OF INVESTIGATION}

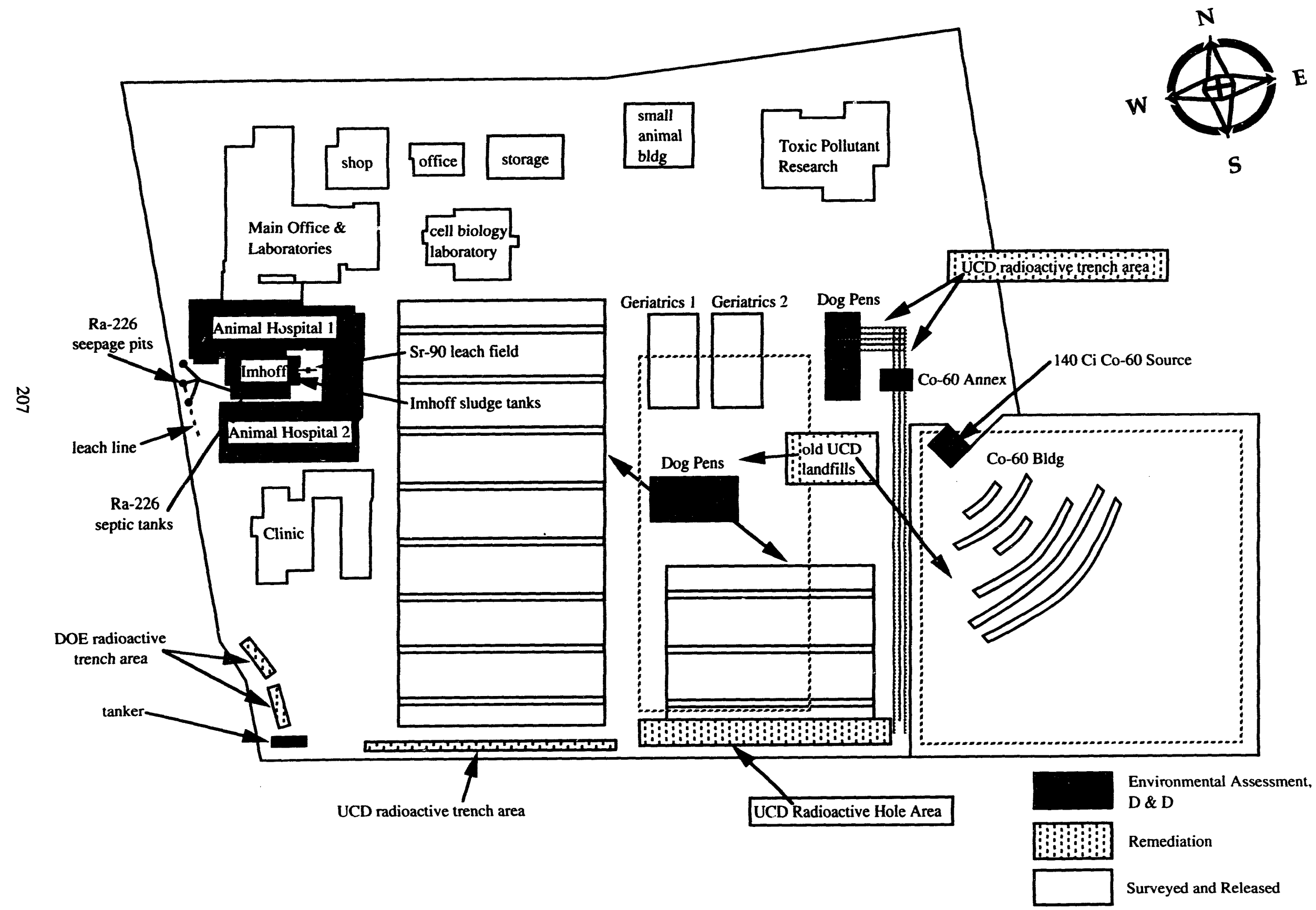




\section{LAWRENCE BERKELEY LABORATORY}

\section{ENVIRONMENTAL RESTORATION AND WASTE MANAGEMENT FACILITIES}

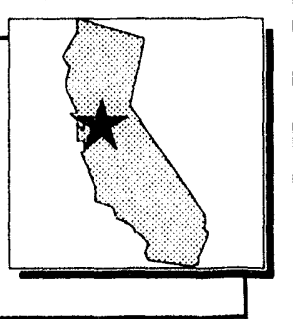

\section{DESCRIPTION}

The 130-acre Lawrence Berkeley Laboratory (LBL) site is located on the western flank of the Berkeley Hills adjacent to the University of California campus. The site is leased to the DOE by the University of California and is bordered on the north by single family residences and on the west by multiunit dwellings, student residence halls, and commercial buildings. A wide range of energy-related research is carried out using LBL facilities, such as particle accelerators, chemistry and biomedical research laboratories, and supporting facilities. Recent accomplishments in waste management at LBL include the renewal of the RCRA Part B Permit for waste handling, commencement of construction of a new and improved Hazardous Waste Handling Facility (HWHF), and continued development of Environmental Safety and Health staff to ensure the continuing safety of LBL operations and the continuing protection of the environment. The principal environmental restoration programs at LBL involve the systematic assessment of soils and groundwater contamination, the investigation of remedial alternatives, and the eventual restoration of the site to levels of cleanliness to be determined through negotiation with the State of California. Other concerns are centered on LBL's sanitary sewer system, which is thought to have been a source of past soils contamination.

\section{AGREEMENTS}

\section{Statute/Type}

Agreement-in-Principle

Part B Corrective Action

Schedule of Completion

\section{Facilities}

LBL

LBL
Parties

DOE/CA

DOE/CA/LBL

\section{Status}

Completed $9 / 6 / 90$

Approved 5/4/93

\section{FACILITIES AND PROJECTS}

Existing Hazardous Waste Handling Facility - Includes portion of buildings 75 and 75A, a yard area for loading and unloading, and a portion of building 69 which is a roofed and fenced storage area.

BEVALAC Facility - The BEVALAC is an accelerator consisting of the Super Heavy Ion Linear Accelerator (SuperHILAC) and the Bevatron Ring. This facility was used for physics research since the 1950s and was closed in 1993. The facility is to undergo Decontamination and Decommissioning following transition to EM.

Sewers - Installation of monitoring equipment.

Storage Tanks - Removal or upgrades of underground tanks.

Waste Treatment - Install and operate Deionization Regeneration Equipment for Waste Treatment.

Site Restoration - Assessment, remedial design, and remediation of soil and groundwater contamination. 


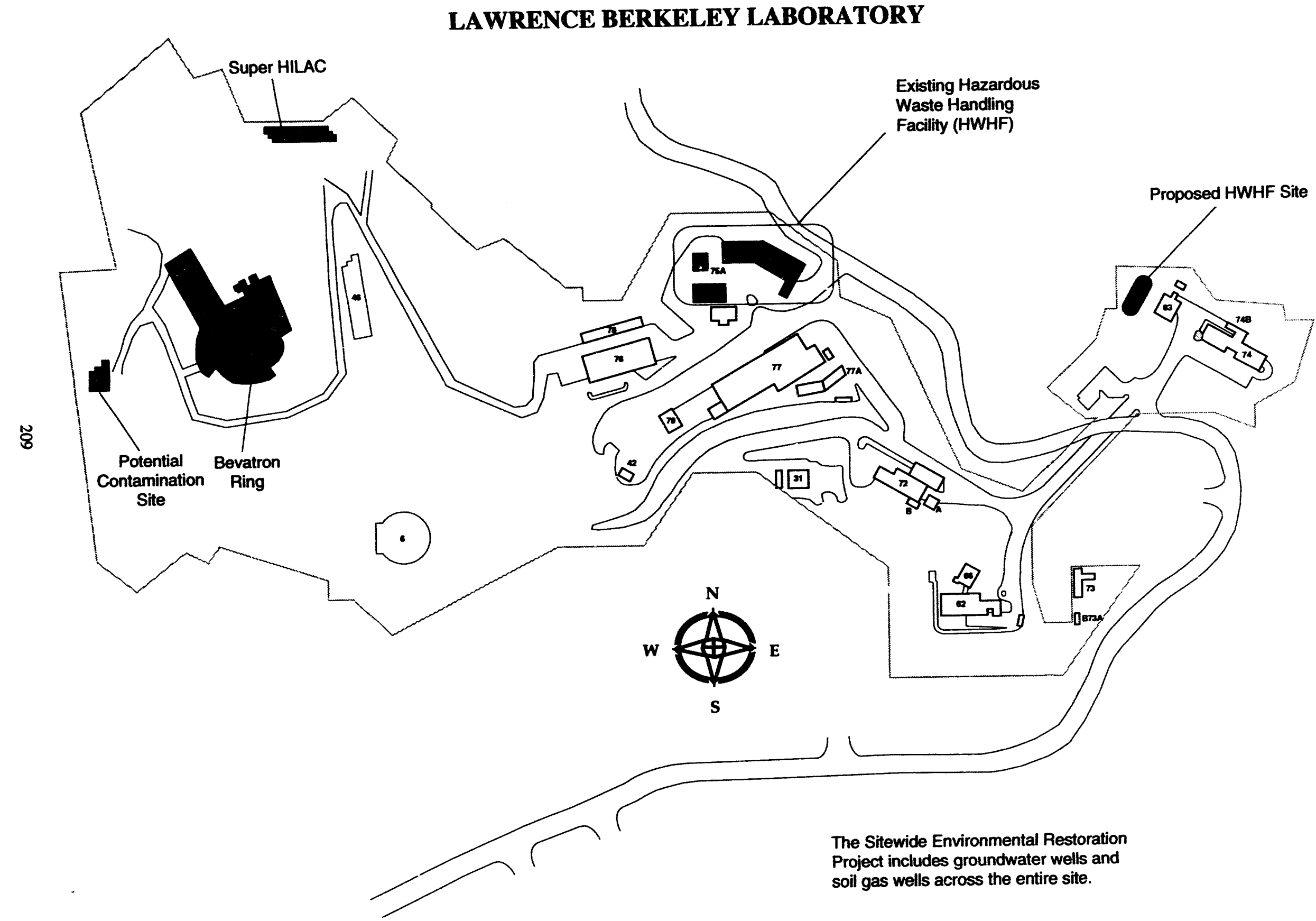




\section{LAWRENCE LIVERMORE NATIONAL LABORATORY}

\section{ENVIRONMENTAL RESTORATION AND} WASTE MANAGEMENT FACILITIES

\section{DESCRIPTION}

The Lawrence Livermore National Laboratory (LLNL) main site (Livermore Site) is a one square mile facility on flat land in the Livermore - Amadore Valley, approximately 40 miles east of San Francisco, on the eastern border of the city of Livermore. This site has an interim status Part B Permit for a Treatment, Storage and Disposal Facility (TSDF) for hazardous and low-level mixed RCRA waste. Past operation, handling, and storage of hazardous materials at the Main Site have resulted in the release and subsequent migration of contaminants into soil and groundwater. There are nonnuclear explosive test facilities at Site 300, located approximately 15 miles east of the main site. A permitted TSDF is located at this site also for the storage of hazardous waste. At Site 300 , soil and groundwater contamination is a resul of processing, testing, and deactivating high explosive materials. Both sites have aboveground and underground wastewater and petroleum tanks.

\section{AGREEMENTS}

\section{Statute/Type}

Agreement in Principle

Toxic Substances Control Act/ Compliance Agreement

California State Hazardous

Waste Law/Compliance Agreement

CERCLA/Federal Facility

hgreement

CERCLA/Federal Facility

Agreement

NESHAPS
Facilities

LLNL

LLNL

LLNL, Site 300

LLNL, Livermore Site

LLNL, Site 300

LLNL
Parties

DOE/CA

DOE/EPA

DOE/CA

DOE/EPA/CA

DOE/EPA/CA

DOE/EPA/CA
Completed 3/19/87

Completed 11/2/88

\section{Status}

Completed 9/6/90

Completed 9/25/87

Completed 6/29/93

Pending; Completion Expected 1/94 


\section{FACILITIES AND PROJECTS}

\section{Livermore Site}

\section{Waste Management Facilities}

The waste management facilities at the LLNL Livermore site are located at the Building 514 Complex, the Building 612 Complex (in the southeast corner of the LLNL Livermore site), and Building 693 (in the northeast corner of the site). There is a storage area for classified hazardous and mixed waste adjacent to Building 233.

\section{Storage Areas 514-1 and 514-2}

These areas are designated for the storage of mixed waste. They consist of epoxy-coated, covered concrete storage pads surrounded by a 12"-high berm. Although Area 514-1 is designated to store mixed waste, the area is used to store product chemicals. This is also the proposed area for new process equipment (i.e., evaporator, centrifuge, carbon adsorption unit, and blending station) to be used for processing hazardous wastes.

Storage Area 514-2 is subdivided into three areas by concrete berms in order to separate incompatible chemical wastes. The types of mixed waste stored in these areas include radioactive acid and alkaline solutions; dilute coolant with oil residue; and wastes containing low concentrations of metals, including copper, beryllium, chromium, nickel, and zinc.

\section{Storage Area 514-3}

This area is used as a portable tank and container storage area to store waste prior to treatment at the wastewater treatment tank farm. The types of waste stored in these areas include acid and alkaline solutions; dilute coolant with oil residue; and wastes containing low concentrations of metals, including copper, beryllium, chromium, nickel, and zinc. The majority of these wastes contain radioactive constituents and are consequently treated as mixed waste. The area is also used to store empty tanks. The area has a total secondary containment capacity of 17,906 gallons. The current permit limits total inventory to 17,600 gallons or 32055 -gallon drums.

\section{Building 612 Comrlex}

The Building 612 Complex consists of the following waste management units.

- Building 612: Lab packing, container crushing, container storage Building 612 houses the drum crusher for hazardous or radioactive drums and containers, the storage area that supports the lab packing of small quantities of nonradioactive waste chemicals and the bulking of corrosive materials, a mixed waste storage area, and a low-level radioactive waste compactor/baler.

- 612-1 and 612-5: Radioactive and mixed waste storage areas Area 612-1 consists of two enclosed tents constructed of plastic-coated canvas. Tent A is 49 feet $x 98$ feet with a maximum capacity of approximately 3,800 cubic yards of solid waste ( 922 cubic yards of mixed waste). The total permitted capacity for mixed waste is 995 cubic yards. The remaining capacity can be used to store low-level waste.

Area 612-5 consists of a fenced area and a tent made of plastic-coated canvas. The fenced area contains four 8 feet $\times 8$ feet $\times 40$ feet containers used to store classified solid mixed wastes. The tent is 49 feet $\times 89$ feet with an estimated storage capacity of approximately 3,445 cubic yards of waste. The total permitted capacity for mixed waste is 995 cubic yards. The remaining capacity can be used to store low-level waste. 
- 612-2: Hazardous and mixed waste storage area

Storage area $612-2$ is a 30 feet $\times 47$ feet covered area surrounded by a 6"-high concrete berm used for storage of hazardous and mixed waste. The containment capacity of the bermed area is approximately 3,700 gallons. Liquid wastes are stored in the area in 55-gallon drums or smaller containers (generally 5 gallons or less) and are placed on secondary containment pallets.

- 612-4: Receiving, segregation and storage area

Area 612-4 is the primary receiving, segregation, and storage area for most wastes generated at LLNL prior to their distribution to the appropriate treatment, processing, or disposal site. The 42 feet $x 100$ feet area is covered by a roof and has an epoxy-coated concrete floor that is subdivided into five areas by berms that provide secondary containment. Three of the areas can store 14455 -gallon drums each and the other two can store 21655 -gallon drums each, totaling 864 55-gallon drums.

- Building 614: West Cell Storage, East Cell Storage

Building 614 is divided into eight rooms or cells for long-term storage of hazardous wastes and bulking of small quantities of compatible materials. The types of waste handled and stored in these cells may vary depending on need. Only compatible wastes, however, are managed in any room at one time. Wastes stored in these cells include, but are not limited to the following: waste mercury, oxidizers, flammables, alkali and earth alkali solids, chlorosolvents and oils, caustics, acids, and compressed gases.

The four cells on the west side of the building each have a maximum storage capacity of 168 gallons of waste. These cells may also be used to store radioactive and mixed wastes. The four cells on the east side of the building each have a maximum storage capacity of 880 gallons of waste. In addition to storage, the east cells may also be used for bulking small quantities of compatible materials.

- Building 625: Container Storage

This building handles and stores transuranic and transuranic mixed wastes and wastes regulated under the Toxic Substances Control Act such as polychlorinated biphenyls (PCB) and asbestos. It has a total floor space of approximately 4,800 square feet. An epoxy-coated concrete berm inside the building separates the radioactive wastes (east side) from the nonradioactive wastes (west side) and provides a secondary containment capacity of about 17,954 gallons. Wastes are typically stored in steel drums or steel boxes.

\section{Building 693 - Chemical Waste Storage Facility}

This building will replace the hazardous waste drum/container storage area (612-3). The 80 feet $\times 120$ feet storage facility contains four bays, each 30 feet $x \mathbf{8 0}$ feet separated by walls with the floor areas surrounded by 6"-high berm for containment. The floor of each bay is epoxy lined concrete and is sloped toward the center into a separate sump to allow for detection and removal of liquids.

Each bay in the bermed storage area has a containment capacity to allow 38455 -gallon drums (assuming double stacking) or a total of 1,536 drums. Because Building 693 was intended to replace the storage area 612-3, the EPA and California Department of Health Services approval (April 1991) for this building limits storage to 74,470 gallons or 1,354 55-gallon drums, the size of the 612-3 area. When the RCRA Part B Permit application is approved, operating capacity for this building is planned to increase to 84,480 gallons.

\section{Building 233 - Classified Mixed Waste Storage Unit}

The location of this two-bay storage area is adjacent to the east wall of Building 233. The area was originally constructed as a waste accumulation area. Controlled materials stored in Building 233 include precious metals, beryllium, lithium, transuranic waste, and various other hazardous, radioactive, and mixed wastes. Precious metal wastes are also accumulated prior to being sent for recovery. 
LLNL plans to complete the 6" berm perimeter providing the north bay with adequate containment capacity to store 12855 -gallon drums. The south bay will have adequate containment capacity to store 14455 -gallon drums. Until this berm is installed, LLNL plans to store only solid waste in this area or to use secondary pallets that provide adequate containment.

\section{Closed Facilities}

There are three treatment and storage facilities that have been shut down or closed. The three facilities are Building 419, a radioactive and mixed waste decontamination and treatment facility, Storage area 612-3; and the Building 624 incinerator.

\section{Building 419}

Building 419 was previously used for equipment decontamination and size reduction as well as solidification of mixed wastes. This building is not being used because of seismic concerns about building design and construction. LLNL is conducting an engineering evaluation to determine the feasibility of bringing the facility up to seismic standards; however, the facility is no longer used to handle and/or treat radioactive, hazardous, or mixed wastes.

\section{Area 612-3}

The drum/container storage area, Area 612-3, was being used on an interim basis to store packaged hazard waste materials while awaiting shipment to a licensed treatment, storage, and disposal facility. The closure plan for this area and the permit to operate Building 693 as a hazardous drum/container storage area was approved in April 1991 by the EPA and the California Department of Health Service, allowing LLNL to close this area.

\section{Building 624}

Building 624 was the waste incinerator complex. LLNL has withdrawn its permit application for incinerating wastes, and the closure plan to dismantle the unit has recently been approved by the EPA and the California Department of Health Services. The storage area associated with the unit (Area 612-2) will continue to be used to store hazardous and mixed wastes.

\section{Decontamination and Decommissioning Facilities}

\section{Building 212}

Building 212 is the Tanden Accelerator Building. It formerly housed a machine shop, plating shop, and an electronics fabrication shop. It is likely that solvents were used in machine and electronics work. PCE has been detected in wells nearby, but at low level. TCE has been detected at a concentration of $150 \mathrm{ppb}$ in ground water.

\section{Building 281}

Building 281 is the Nuclear Chemistry Building. Both radioactive and non-radioactive hazardous wastes are generated in nuclear chemistry operations. Between 1982 and 1987, these wastes were stored at the Container Storage Area pending removal to the Waste Yard Receiving Area.

\section{Building 292}


Building 292 is the RTNS II Building. Inside the building, there was a Machine Shop consisting of a structure with 2 covered tanks and one open sink. The covered tanks contained chromic and nitric acid, separately. Metal parts were cleaned by dipping in tanks followed by subsequent rinsing. Rinse water may have been discharged to the sanitary sewer.

\section{Building 412}

Building 412 is the Environmental Research Building. A portion of the building was previously used for Hot Cell Research. Inside the building, at the east end, there was a container storage area. Two adjacent concrete pits with a shared wall were used to store radioactive waste drums.

\section{Environmental Remediation Projects}

\section{Treatment Facility A (TFA)}

This facility is a ground water treatment facility located just north of Arroyo Seco near Vasco Road in the southwest part of the LLNL Livermore Site. Its purpose is to treat ground water containing VOCs. Ground water in the TFA vicinity is being pumped to hydraulically control the southwestern portion of the groundwater plume. The primary contaminants in the ground water at this location are PCE at about $100 \mathrm{ppb}$ and 1,1-DCE at $9 \mathrm{ppb}$. In addition, TCE, Freon 113, 1-1-DCA, 1,1,1-TCA, and chloroform are also present in influent ground water, each at concentrations of $4 \mathrm{ppb}$ or less. TFA consists of a commercially available ultraviolet light/hydrogen peroxide ground water treatment unit and an air stripper. The treated groundwater is discharged via a pipeline to a recharge basin, and it is used onsite at LLNL in cooling towers and/or for landscape irrigation.

\section{Gasoline Spill Area}

This area housed LLNL's automotive garage and fuel-dispensing facility until November 1986 . Located near the southern boundary of LLNL, this area overlaps a portion of the Southeast Corner Area. From 1952 through March 1979, approximately 17,500 gallons of leaded gasoline may have been lost from the southernmost of four underground fuel tanks in the area. However, this amount includes unrecorded removal of gasoline at the selfserve pumps for government vehicles. A slow-moving plume of fuel hydrocarbons is present beneath this area and extends south of East Avenue onto DOE property occupied by Sandia National Laboratory.

\section{Site 300}

LLNL Site 300 is a remote explosives testing ground for the theoretical and developmental weapons work performed at LLNL. Located approximately 15 miles southeast of the LLNL Livermore site, LLNL Site 300 occupies approximately 7,000 acres in Alameda and San Joaquin counties. The terrain varies from rolling hills to canyons, from 525 to 1,750 feet above sea level. Current facilities are located in six areas: the firing area, a physical and dynamic test area (Building 833), an environmental test complex (Building 834), a high explosives process area, a pit area, and the general services area.

\section{East and West Firing Areas (EFA/WFA)}

The total Firing Area comprises over 5 square miles; contains 27 buildings, 4 High Explosive (HE) magazines, 6 above ground water tanks, and 9 pits. The majority of activities in the EFA/WFA involve testing of conventional explosives assemblies that can be used to detonate nuclear devices. No actual fissionable material is used in these hydrodynamic tests. Until 1988, debris from the tests were disposed of in landfill pits within the boundaries of the EFA/WFA. 


\section{LAWRENCE LIVERMORE NATIONAL LABORATORY}

Facilities within the EFA/WFA include the Hydrodynamics Diagnostics Facility and Complex, housing an electron beam linear accelerator; the Dynamic Test Complex, for vibration and shock testing; and the Materials Management Storage Facility. Other experiments related to weapon testing were performed with the Advanced Testing Accelerator. The plumes of contaminants in groundwater contain tritium, TCE, and Freon 113.

\section{Building 833 Area}

The Building 833 Area covers about 141 acres in the southeastern portion of Site 300, bordering on the General Services Area (GSA), the HE Process Area, and the Building 834 Complex. Facilities for physical properties testing, dynamic testing, and long-term thermal testing are included, along with several HE storage magazines.

\section{Building 834 Complex}

The Building 834 Complex covers 326 acres in the southeast end of Site 300, adjacent to the General Services Area. The dominant topographical feature is an east-west-trending ridge. The Building 834 complex is located at the northern end of the ridge. To the southeast of the ridge is a valley that contains the Building 832 Complex, Building 831, and Building 838. A total of 21 permanent buildings are included in the Environmental Test Complex. The complex is used primarily for the thermal testing (cycling, shocking, and soaking ) of test specimens which may contain explosives, radioactive or toxic materials, and mock high explosives.

\section{High Explosives Process Area}

The HE Process Area occupies approximately 934 acres in the southern and southeastern portions of Site 300 . It lies in an area of steep, hilly terrain with deep northwest-southeast trending ravines that lead to Corral Hollow Creek. The HE Process Area was constructed to chemically formulate HE compounds and to mechanically press and machine those compounds into shaped detonation devices. HE shavings and debris were washed into concrete lined rinsewater drainage trenches. A clarifier removed particulate matter for destruction, and the filtered rinsewater was discharged into unlined lagoons. Later, double-lined HE rinsewater surface impoundments were commissioned, where sunlight can break down the HE compounds and evaporate the remaining water. Low to moderate concentrations of $\mathrm{HE}$ compounds have been detected near the unlined lagoons and in perched groundwater. TCE has also been detected in soil/rock, soil vapor, and two groundwater-bearing zones.

There are a total of 48 buildings, $22 \mathrm{HE}$ storage magazines/magazettes, and 2 trailers that presently support the HE Process Area and western GSA.

\section{Pit Area}

The Pit 6 Area covers 1504 acres in the southwest corner of Site 300. There are three previously used solid waste disposal sites in the southem part of the Pit 6 Area: the pit 6 landfill, Paper Canyon, and the gate 110 debris trench. The Carnegie area, in the southeast portion, was once a mining and industrial area; scattered metal debris has been found there. The only LLNL buildings located there are east of pit 6 and are used to support firearms training operations.

\section{General Services Area (GSA)}

The GSA covers 83 acres and is located in the southeast corner of Site 300 . It contains a cluster of 11 buildings, including administration offices and equipment fabrication and repair shops and encompasses the sewage treatment pond and an overflow pond. Remedial investigations also cover adjacent private property along Corral Hollow Creek. 


\section{LA WRENCE LIVERMORE NATIONAL LABORATORY LIVERMORE SITE}

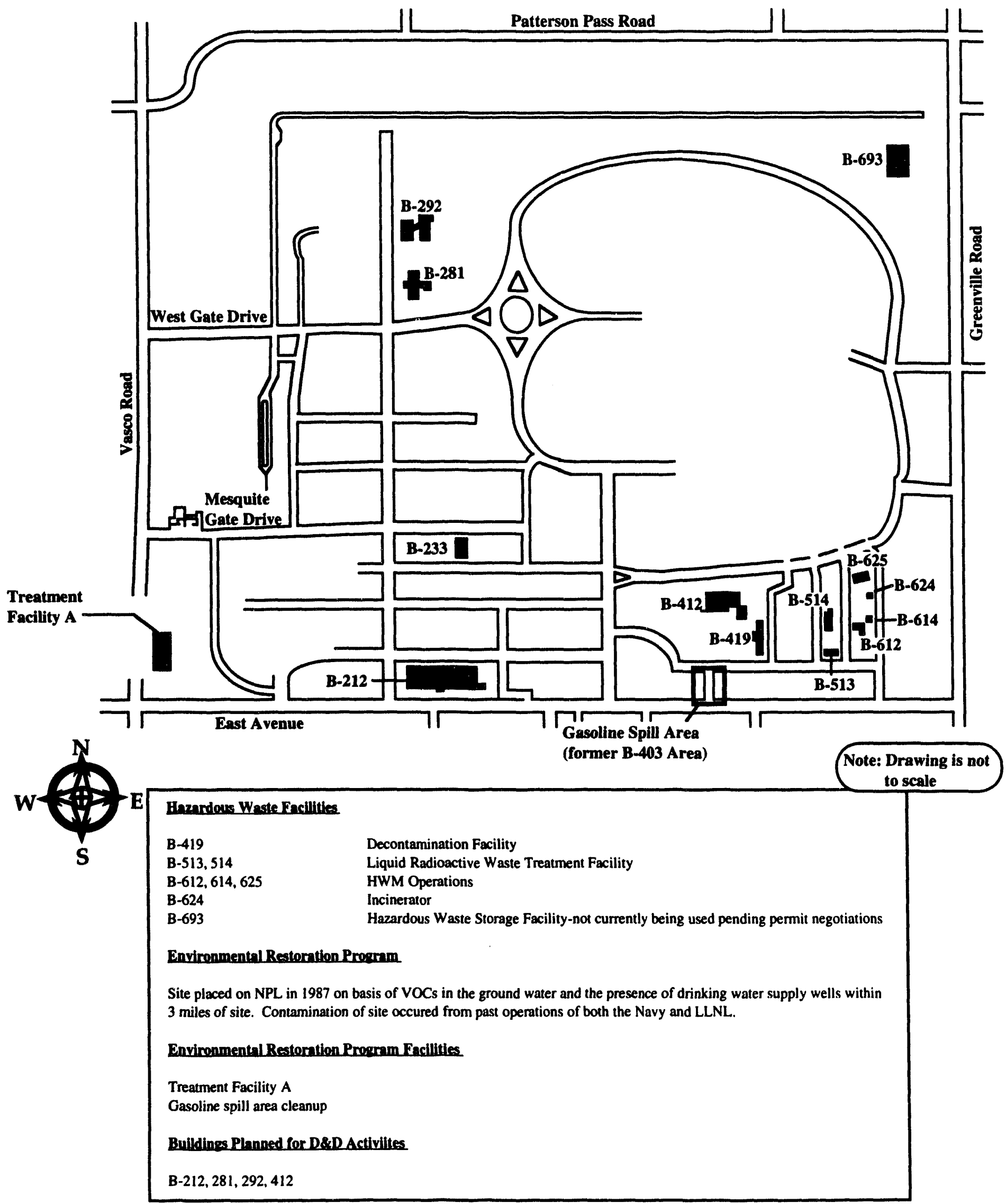




\section{LA WRENCE LIVERMORE NATIONAL LABORATORY \\ SITE 300}

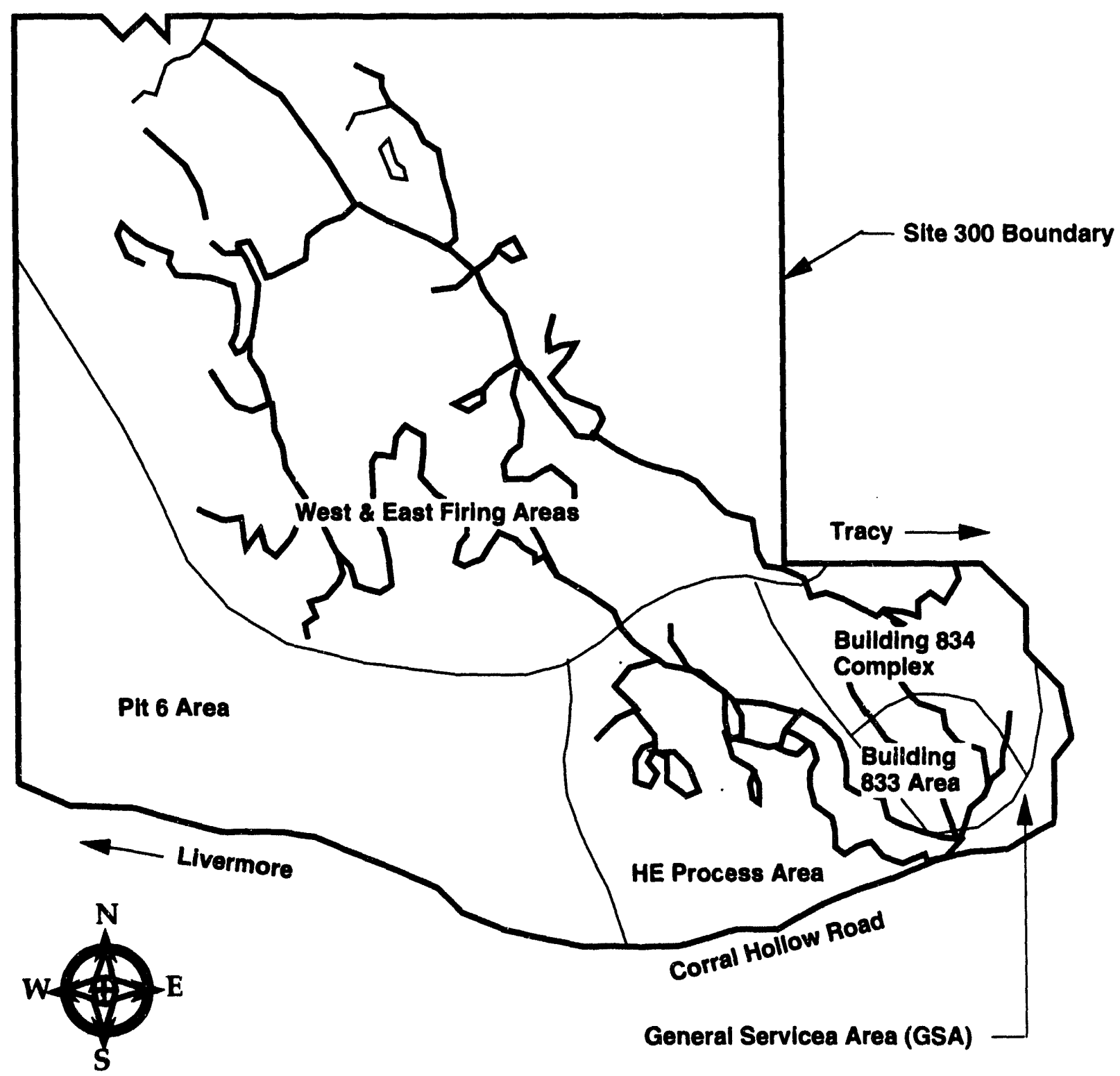




\section{SANTA SUSANA FIELD LABORATORY}

\section{ENVIRONMENTAL RESTORATION AND WASTE MANAGEMENT FACILITIES}

\section{DESCRIPTION}

The Santa Susana Field Laboratory (SSFL), consisting of a total of 2700 acres, is located in the Simi Hills of Ventura County, approximately 30 miles northwest of downtown Los Angeles, California. DOE operations are conducted in Rockwell International-owned and DOE-owned facilities on a 290-acre site. The Energy Technology Engineering Center (ETEC) portion of the SSFL consists of government-owned buildings on a 90-acre site. The Rockwell facilities include former fabrication facilities, a hot cell, a reactor test building, a storage vault, an on-site transport cask, and other radiologically contaminated support laboratories and areas. The ETEC facilities are used to test systems and components for use in energy, power conversion, and liquid metal development programs. At SSFL, outside of ETEC, DOE is funding the decontamination and decommissioning (D\&D) of a Rockwell-owned, Nuclear Regulatory Commission-licensed hot cell that was used for DOE activities. Corrective actions, waste management, and environmental restoration activities are ongoing at a number of facilities and areas at the site. An Agreement-in-Principle is in place with the State of California. This establishes State oversight to ensure environmental compliance at DOE facilities in California.

\section{AGREEMENTS}

$\begin{array}{llll}\text { Statute/Type } & \text { Facilities } & \text { Parties } & \text { Status } \\ \text { Agreement-in-Principle } & \begin{array}{l}\text { Energy Technology } \\ \text { Engineering Center }\end{array} & \text { DOE/CA } & \text { Completed 9/6/90 }\end{array}$

\section{FACILITIES AND PROJECTS}

Building 020 "Rockwell Hot Lab" - This four cell hot lab is owned and was operated by Rockwell in support of reactor post-mortem activities and more recently fuel decladding efforts for DOE/Defense Programs. The D\&D of this facility, which will result in demolition and green fielding, is now approximately $70 \%$ complete. Although the majority of contamination has been removed, funding priorities will delay final completion to FY 1998.

Building 005 - This facility was formerly a fuel fabrication facility in support of early reactor development efforts. A small amount of radioactive contamination remains in isolated sections of ductwork. D\&D of this facility is complete. Release will occur in mid 1994.

Building 029 - This facility is a RCRA permitted storage area for hazardous wastes. Currently alkali metal wastes are stored here awaiting treatment in Building 133.

Building 133 - This facility houses a thermal decomposition unit for treatment of alkali metals, primarily sodium. The facility is permitted by the Ventura County Air Pollution Control District and the California Department of Health Services. Basically the sodium is oxidized and then water is used to convert the oxide to sodium hydroxide. The sodium hydroxide is utilized for acid neutralization by Rockwell. 
Building 024 - This facility formerly housed the test reactors for the Space Nuclear Auxiliary Power (SNAP) Program. The reactors and all contaminated equipment have been removed from the building. The concrete reactor chambers exhibit activation from reactor operations at extremely low levels $(<0.5 \mathrm{mr})$. Restricted access is being maintained for the facility and studies are under way to determine whether a feasible means exists to remove the contamination to "unrestricted use" levels short of demolition of the structure.

RD33 and RD34 - These numbers refer to two each of three well clusters immediately off-site of the Rockwell property. These well clusters were drilled to determine the extent, if any, of groundwater contamination. The RD33 cluster showed VOC contamination at approximately $50 \mathrm{ppb}(\mathrm{mcl}$ is $5 \mathrm{ppb}$ ), and trace contamination of tritium in the shallow well. RD34 showed VOC contamination at $6 \mathrm{ppb}$, also in the shallow well, and no tritium. These wells will continue to be monitored and additional wells off-site may be required.

Building 059 - This facility housed a series of test reactors for the SNAP program. D\&D of this facility has been completed in FY 1993 and it will be released in FY 1994. Groundwater monitoring adjacent to this facility has indicated tritium, presumably as the result of water in-leakage to the reactor vessel area. Groundwater monitoring will continue as part of the site-wide RCRA Facility Investigation.

Building 064 - This facility was formerly used as a nuclear materials storage area, and most recently used to store contaminated soil prior to shipment for disposal. Remediation of soil adjacent to the facility was completed in FY 1993. This facility will be released for unrestricted use in FY 1994.

Sodium Disposal Facility - This facility (Building 886) is an area of approximately two acres that was used in the past to wash sodium from test articles with water. Surveys of the area indicated that it was contaminated with volatile organics and low levels of radioactivity. Groundwater adjacent to the area is contaminated with volatile organics. This area has been the subject of a Closure Order by the Regional Water Quality Control Board. Remediation of this facility will be complete in the 1st Quarter of FY 1994.

RMDF - The Radioactive Material Disposal Facility (RMDF) is a collection of several buildings which together comprise a permitted treatment, storage and disposal facility. This facility is used for decontamination, size reduction, and packaging of radioactive materials from $D \& D$ operations on site. As such, this will be the last facility to be released under the EM program. A phased D\&D is scheduled to start in FY 1995 and continue through FY 1998.

Building 100 Trench - This area was formerly utilized for the disposal of construction debris. Preliminary assessment has determined that limited areas of hazardous material contamination are present. Remediation is scheduled for FY 1995. 


\section{SANTA SUSANA FIELD LABORATORY, AREA IV}

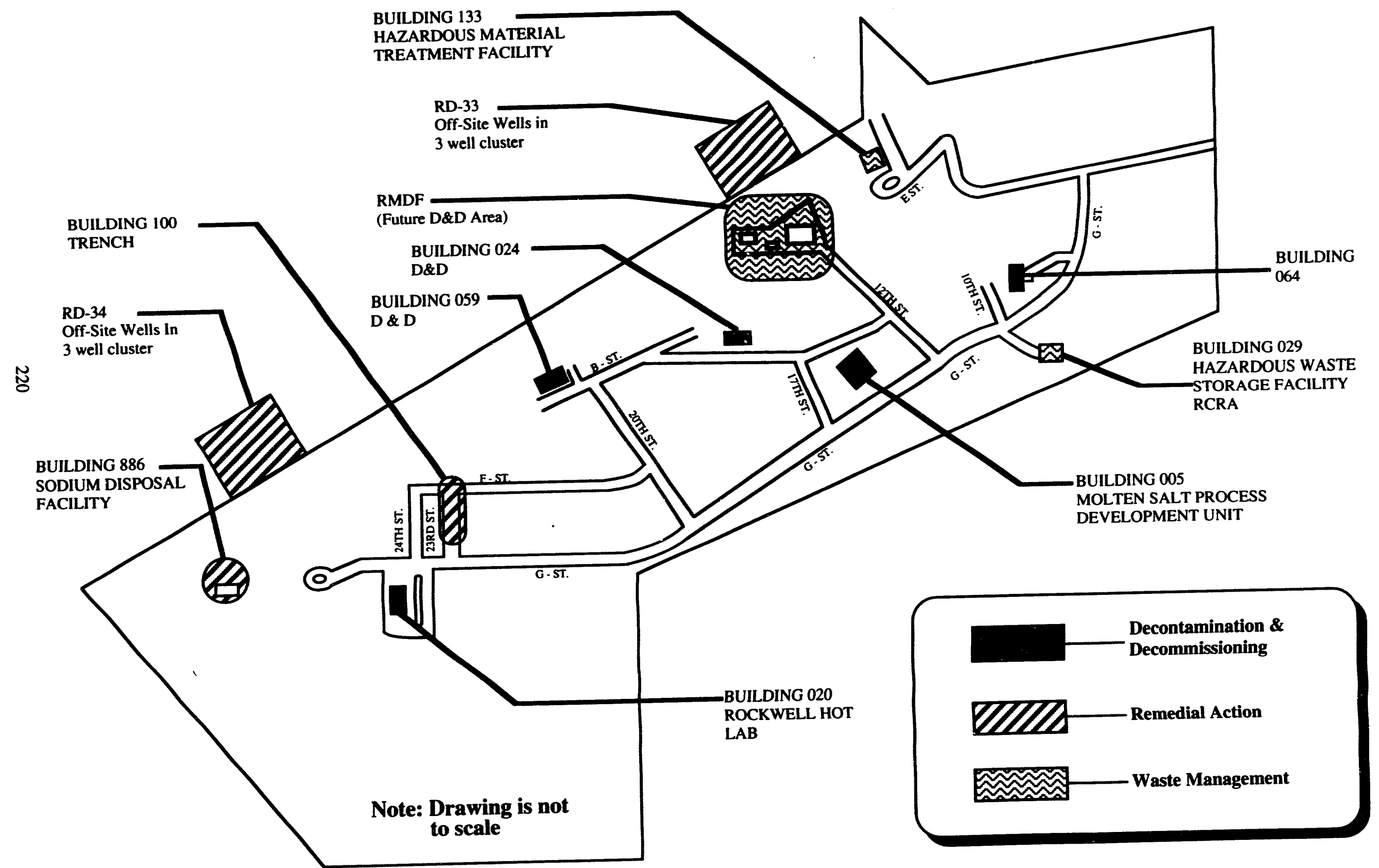




\section{STANFORD LINEAR ACCELERATOR CENTER}

\section{ENVIRONMENTAL RESTORATION AND} WASTE MANAGEMENT FACILITIES

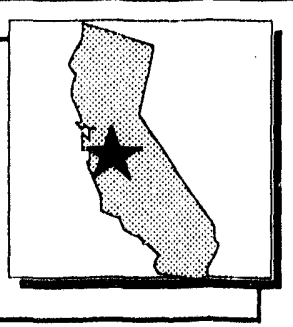

\section{DESCRIPTION}

The Stanford Linear Accelerator Center (SLAC) is operated by Stanford University under contract to DOE. The 426-acre site is located on the San Francisco Peninsula between San Francisco and San Jose, California. SLAC, established in 1962, is an energy research facility dedicated to research and development of new techniques for high-energy accelerators and experimental apparatus.

Past waste management practices and facility operations have resulted in polychlorinated biphenyl (PCB) contamination of soils and volatile organic compound contamination of groundwater, which will require assessment and remediation.

\section{AGREEMENTS}

Statue/Type $\quad$ Facilities $\quad$ Parties

$\begin{array}{lll}\text { Agreement-In-Principle SLAC DOE/CA Completed 9/6/90 } & \text { D }\end{array}$

\section{FACILITIES AND PROJECTS}

Underground Solvent Tank - The first of three sites at SLAC of known groundwater contamination. Site is being monitored quarterly by order of the San Francisco Regional Water Quality Control Board. The Preliminary Assessment/Site Investigation (PA/SI) phase has been completed.

Plating Shop Chemical Storage Building - The second site at SLAC of known groundwater contamination by solvent. Characterization activities are scheduled to commence in FY 1992/1993. PA/SI phase has been completed.

3.0 MW Power Supply - Former PCB spill and cleanup project. Site of twin PCB transformers now drained and pending removal scheduled in FY 1992. Site characterization scheduled for FY 1994. PA/SI phase has been completed and PCB contamination of asphalt and soils has been measured as high as $510 \mathrm{ppm}$.

Substation 505 Power Supply - Soils slightly contaminated with PCBs, at about the State of California Action Level ( $5 \mathrm{ppm})$, caused by past leaking of three PCB-contaminated transformers which are scheduled for removal in FY 1992/1993. PA/SI phase completed. Site characterization scheduled for FY 1994.

IR-S. IR-6 Drainage Ditches - A separate Remedial Investigation (RI) is being performed for the drainage area where PCBs have contaminated off-site soils. The project scope has been expanded to identify possible upstream point sources which empty into the IR-6 drainage system. This site will continue through the CERCLA process during FY 1994-1996: completion of the RI/Feasibility Study (FS) in FY 1994; Remedial Action Plan and Record of Decision in FY 1995; and Remedial Design and Remedial Action in FY 1996. 
IR-8 Power Supply - PCB contamination of soils in area registers as high as $3200 \mathrm{ppm}$. Area was the site of six PCB-filled transformers which have been retro-filled to levels below $5 \mathrm{ppm}$. PA/SI completed, and RI/FS activity is scheduled to commence in FY 1994.

Master Substation - Soils/inactive area consists of four separate areas where PCBs were previously stored and soil contamination ranges from 5 to $50 \mathrm{ppm}$. There are two additional areas of concern at the Master Substation where PCB soils are suspected of leaking, and PA/SI efforts are scheduled for FY 1992/1993. RI/FS work at this site is scheduled to commence in FY 1994.

Former Hazardous Waste Storage Area - The third site at SLAC of known groundwater contamination by solvents. PA/SI activity complete and RI/FS work at site is scheduled to commence in FY 1992/1993.

Hazardous Waste Storage Yard Eroded Asphalt Area - Site is a potential source of hazardous waste contamination of soil because the bermed area is not impermeable as a result of eroded and cracked asphalt. Contamination of soil by heavy metals has been ascertained. Site characterization activities are scheduled to commence in FY 1994.

Radioactive and Mixed Waste Storage Yard (RAMSY - The RAMSY is currently used for staging, inspection, segregation, package consolidation, and storage of radioactive and mixed wastes generated at the SLAC, prior to shipment off-site for treatment and/or disposal. 


\section{STANFORD LINEAR ACCELERATOR CENTER}

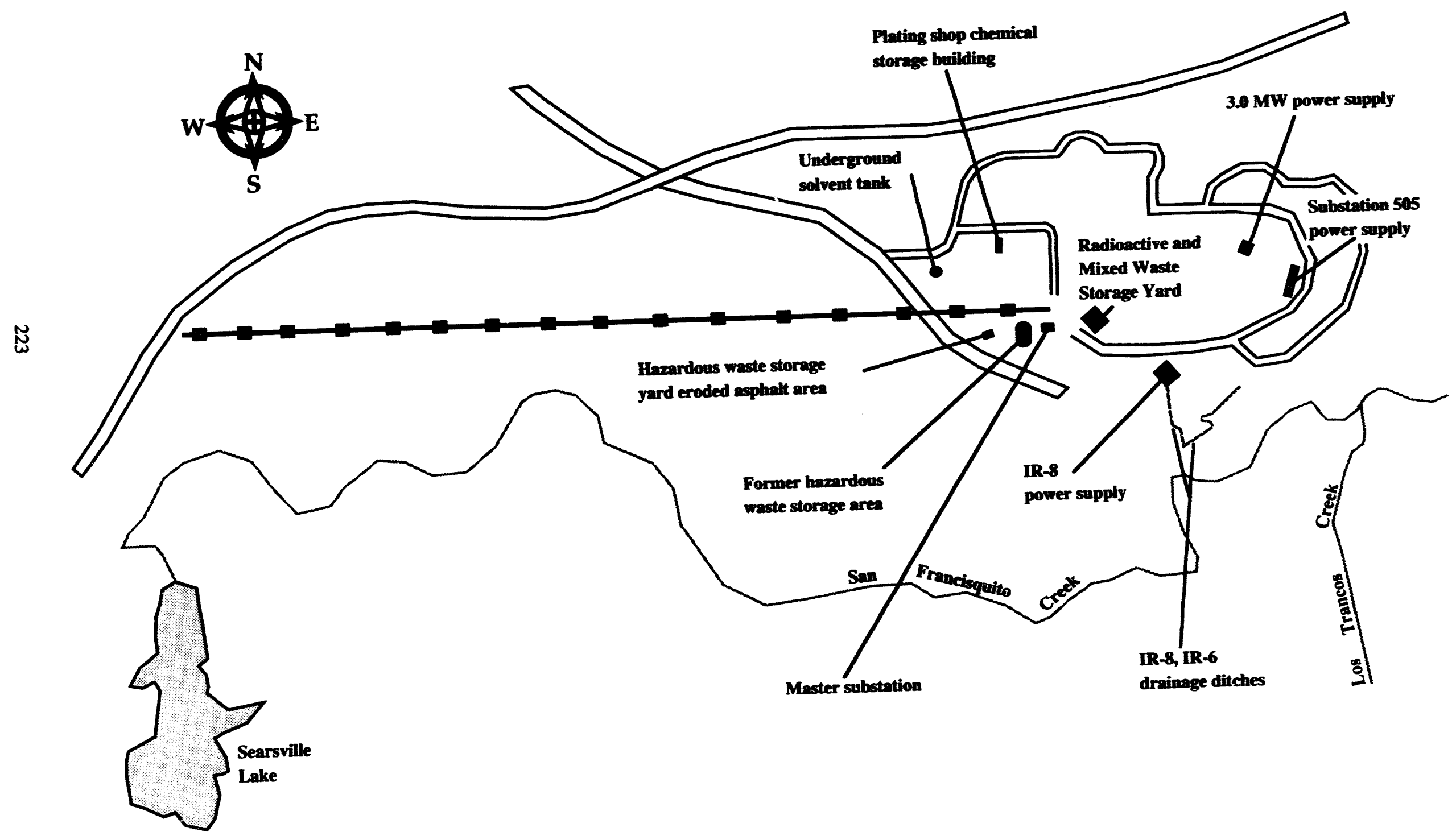




\section{SAVANNAH RIVER SITE}

ENVIRONMENTAL RESTORATION AND

WASTE MANAGEMENT FACILITIES

\section{DESCRIPTION}

The Savannah River Site (SRS) produces nuclear materials, primarily tritium and plutonium, for national defense. SRS is located in south central South Carolina, bordered on the south western side by the Savannah River. The closest major population centers are Aiken, South Carolina, and Augusta, Georgia. The site comprises five reactors, two chemical separations facilities, one reactor fuel manufacturing facility, and other administration and support facilities. The total area of the site is approximately 325 square miles. The production facilities occupy less than five percent of the site area.

\section{AGREEMENTS}

\section{Statute/Type}

Clean Air Act/Compliance

Agreement

Agreement-in-Principle

Clean Water Act/Compliance

Agreement

Safe Drinking Water Act/

Compliance Agreement

RCRA/Compliance Agreement

Clean Water Act/Compliance

Agreement

RCRA/Compliance Agreement

Clean Air Act/Compliance

Agreement

Federal Facilities

(RCRA/CERCLA) Agreement
Facilities

SRS

SRS

SRS

SRS

SRS

SRS

SRS

SRS

SRS
Parties

DOE/SC

DOE/SC

DOE/SC

DOE/SC

Completed 10/7/87

DOE/SC

Completed 9/5/90

DOE/EPA

Completed 1/23/87

DOE/EPA

Completed 4/23/92

DOE/SC

Completed 9/4/87

DOE/EPA/SC

Effective 8/16/93

Phase I Completed 3/5/92

Completed 7/31/91 


\section{FACILITIES AND PROJECTS}

Sanitary Waste Landrill (Area B) - SRS maintains its own sanitary waste landfill. The existing landfill has documented groundwater contamination and will cease operation when the new sanitary landfill is available. The new sanitary landfill will provide a 20 -year capacity for sanitary waste disposal, incorporating a synthetic liner and leachate collection system.

Decontamination and Decommissioning of Inactive Facilities - There is currently one D\&D project in progress to decommission the Separations Equipment Development (SED) Facility. One additional facility, the Heavy Water Components Test Reactor (HWCTR) adjacent to B-Area, was transferred to EM in FY-1993 for Surveillance and Maintenance. Approximately 200 buildings elsewhere on the site have been identified as surplus by Defense Programs, and are being investigated as candidates for decommissioning.

Non-Radioactive Hazardous Waste Storgae. Central Shops (Area CS) - Three South Carolina Department of Health and Environmental Compliance (SCDHEC) - permitted storage buildings (Buildings 710-B, 645-N, 645$4 \mathrm{~N}$ and area adjacent to Buildings $645-\mathrm{N}$ and $7645-4 \mathrm{~N}$ ) currently store non-radioactive hazardous waste.

Mixed Waste Storage - Mixed waste is currently placed in interim storage in Building $645-2 \mathrm{~N}$ in Central Shops.

Low-Level Waste Disposal Facility. (Area E) - The storage and disposal of solid radioactive waste produced at the SRS as well as DOE shipments from off site is handled by the Solid Waste Disposal Facility. The E-area facility occupies 195 acres between the F and H Separations Areas, and includes an old burial ground, the LowLevel Radioactive Waste Disposal Facility, and the Mixed-Waste Management Facility.

E-Area Vault Storage - A 100-acre site in the north portion of E-Area is being developed to meet projected SRS solid low-level radioactive waste storage/disposal requirements for the next 20 years. The site will include the radioactive waste burial ground, the Mixed Waste Management Facility, and the F- and H-Area seepage basins.

Waste Certification Facility - Currently all suspect Transuranic (TRU) waste containers are being stored on TRU pads. The first phase of the Waste Certification Facility (WCF), the Experimental TRU Waste Assay Facility (ETWAF), is used to determine whether the waste is contaminated to a level $>100 \mathrm{nCi} / \mathrm{g}$ and to determine other information required by the Waste Isolation Pilot Plant (WIPP) Waste Acceptance Criteria. The second phase of the WCF includes facilities to bar code and prepare drums for shipment and load the drums into the TRU Package Transporter-II for shipment to WIPP.

Hazardous Waste/Mixed Waste Disposal Facility - This project will provide RCRA-permitted treatment and disposal for solid hazardous and mixed waste that cannot be disposed of in existing or planned facilities. This facility will also eliminate the need to transport hazardous waste off site.

Mixed Waste Storage (Area E) - Mixed waste is currently placed in interim storage at Buildings 643-29E and 643-7G in the E-Area Solid Waste Disposal Facility. This is a SCDHEC-permitted facility and will be in use until the completion of the Hazardous Waste/Mixed Waste Disposal Facility and the CIF. Storage building 645$43 \mathrm{E}$ has been constructed but not yet operational, to provide more storage capacity for mixed waste on site.

TRU Waste Facility (TWE) - This facility will be designed to retrieve and process TRU waste and prepare it for certification and permanent disposal at WIPP or disposal as low-level waste.

High-Level Waste Tank Farm and Evaporator (Area F) - Twenty two F-Area tanks store and process liquid radioactive waste. Two F-Area evaporators volume-reduce the liquid radioactive waste. 
High-Level Waste Tank Farm and Evaporator (Area H) - Twenty nine H-Area tanks store and process liquid radioactive waste. One $\mathrm{H}$-Area evaporator volume-reduces the liquid radioactive waste.

Beta-Gamma Incinerator (BGI) - This low-level waste incinerator operated for several years, serving as a prototype for future incinerator designs. It is no longer in service.

High-Level Waste Maintenance Facility - This facility provides H-Area maintenance.

Emuent Treatment Facility - This facility treats process wastewater that was previously sent to the F- and Harea seepage basins.

Replacement High-Level Waste Evaporator- This project will design and construct an evaporator to replace an existing H-Area evaporator.

New Waste Transfer Facility - This facility will serve as the hub for waste transfers between the F and $\mathrm{H}$ Area Tank Farms, DWPF and ETF.

Extended Sludge Processing - This process treats sludge before it is sent to DWPF.

In-Tank Precipitation (ITP) - This facility treats salt before it is sent to DWPF and Saltstone.

Consolidated Incineration Facility - A rotary kiln incinerator system will be built to treat various site-generated combustible wastes stored at SRS. The waste to be treated will include wastes defined as hazardous by South Carolina Hazardous Waste Management Regulations and Federal RCRA regulations, waste contaminated with low levels of beta-gamma radioactivity, and mixed wastes that are both hazardous and radioactive. The facility will not treat wastes containing dioxins or polychlorinated biphenyls.

Liquid Emuent Treatment Facility (Area M) - This facility treats process wastewater from M Area.

Defense Waste Processing Facility (DWPF) (Area S): This Facility will take liquid high-level radioactive waste and permanently immobilize it as a glass solid (vitrification). The glass will be temporarily stored on site for eventual transport to and disposal in a permanent Federal geological repository.

TNX Semi-Works Facilities (Area T) - These facilities are used to study chemical processing problems and test production-scale equipment and processes.

Saltstone Facility. (Area Z) - This facility will provide processing and disposal facilities for hazardous and lowlevel mixed-waste salt solutions.

RCRA/CERCLA Waste Units, Various Sites - Includes all waste units and groundwater units identified in the Federal Facilities Agreement for assessment/remediation under the RCRA Facility Investigation/Remedial Investigation Program. There are currently over 70 waste sites specifically identified to be characterized. Groundwater is currently under remediation at the $3 / 700$ area. 


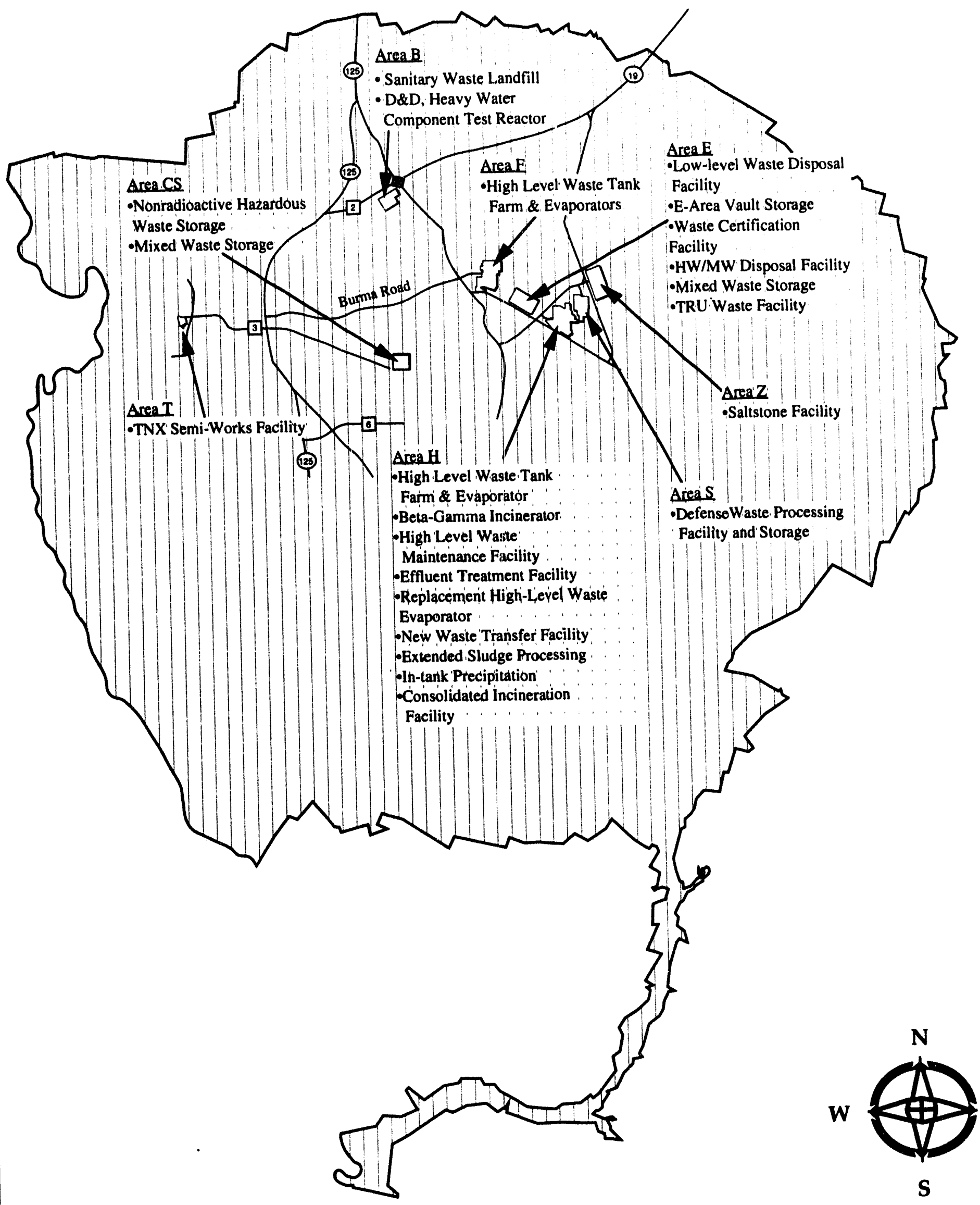



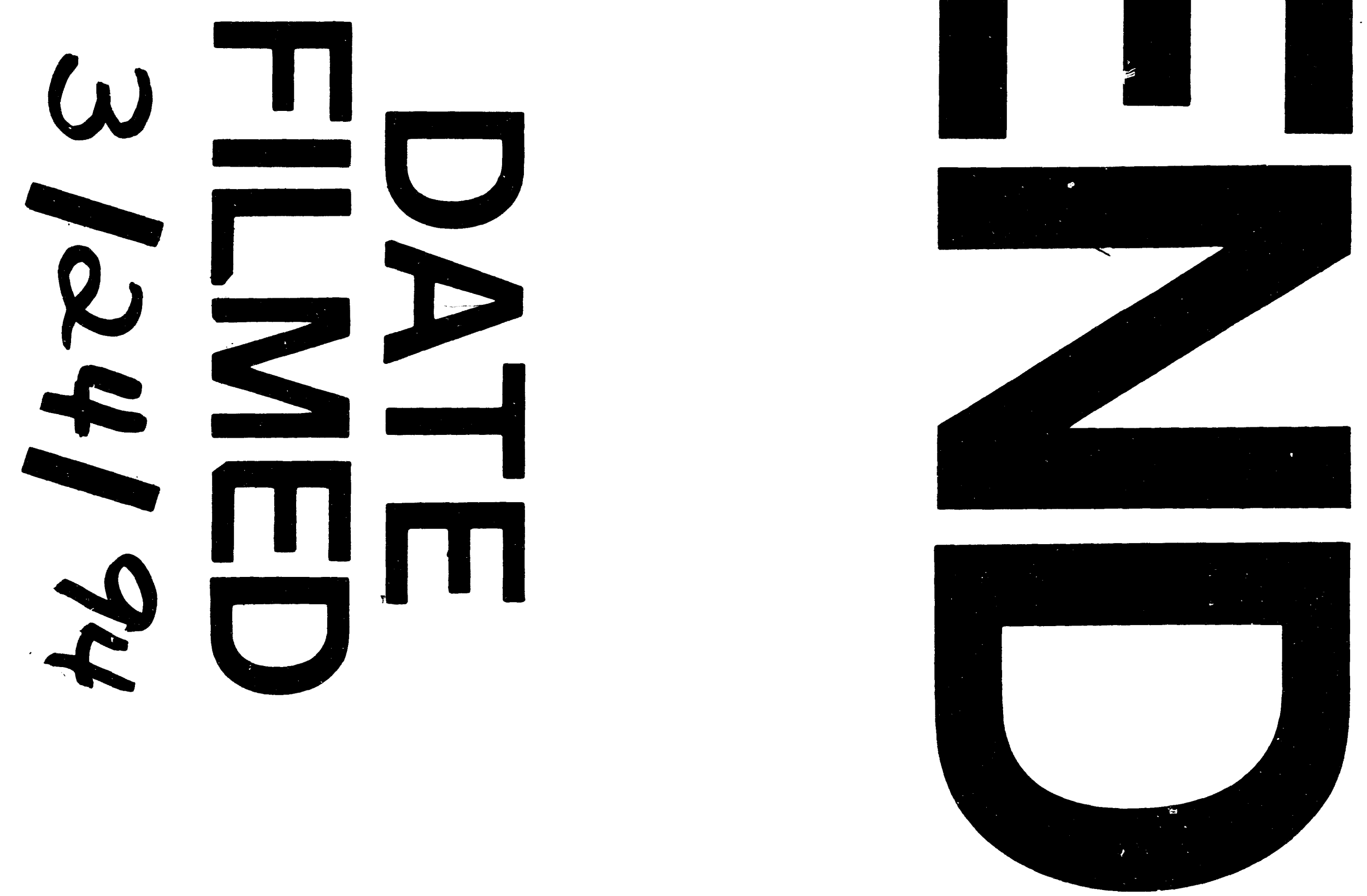
